\title{
ANALYSES OF HYDROLOGICAL AND HYDROCHEMICAL FLUXES IN SElected CATChments OF the CeRRAdo AND AmAZON BiOMES
}

\section{DisSERTATION \\ (CUMULATIVE THESIS)}

to acquire the doctoral degree in mathematics and natural science

"Doctor rerum naturalium"

at the Georg-August-Universität Göttingen

within the doctoral degree program of Geoscience and Geography of the Georg-August University School of Science (GAUSS)

submitted by

\section{Rodolfo LUIz BezerRa Nóbrega}

from Campina Grande, Brazil

Göttingen, 2017 


\section{THESIS COMMITTEE:}

Prof. Dr. Gerhard Gerold (thesis supervisor)

Department of Landscape Ecology, Georg-August Universität Göttingen.

Prof. Dr. Hermann Jungkunst

Department of Geoecology \& Physical Geography, Universität Koblenz-Landau.

\section{MEMBERS OF THE EXAMINATION BOARD:}

$1^{\text {st }}$ Referee: Prof. Dr. Gerhard Gerold

Department of Landscape Ecology, Georg-August Universität Göttingen.

$2^{\text {nd }}$ Referee: Prof. Dr. Hermann Jungkunst

Department of Geoecology \& Physical Geography, Universität Koblenz-Landau.

\section{FURTHER MEMBERS OF THE EXAMINATION BOARD:}

Prof. Dr. Daniela Sauer

Department of Physical Geography, Georg-August Universität Göttingen.

Prof. Dr. Jürgen Schmidt

Soil and Water Conservation Unit, Technischen Universität Bergakademie Freiberg.

Dr. Stefan Erasmi

Department Cartography, GIS and Remote Sensing, Georg-August Universität Göttingen.

Date of oral examination: $24^{\text {th }}$ November, 2017 


\section{Analyses of hydrological and hydrochemical fluxes in selected catchments of the Cerrado and Amazon biomes}

Rodolfo Luiz Bezerra Nóbrega 

"Human perception is not a direct consequence of reality but rather an act of imagination" Michael Faraday 



\section{Acknowledgments}

I would like to thank my parents, Aldany and Rômulo, for their lifelong support and for prioritizing their resources and attention for my education. This acknowledgment extends to my thoughtful wife, Luisa, who supports me at all costs, including the care of our beloved Hugo.

I'm grateful for the support of Prof. Dr. Gerold, who is always accessible and interested in discussing science and research ideas, as well as for being a great project leader with superb professional and personal skills to handle such an extensive research project, in which my Ph.D. research was developed.

My professional development during my doctoral research had a substantial improvement due to the inputs and feedbacks from Dr. Aphonce Guzha, who continually assured the value of robust scientific research and cooperation. His mentoring was fundamental to develop my scientific skills in the field and during the data analysis.

The routine of work would not be the same without my colleagues at the University of Göttingen. Besides the project, this team of great people was hugely responsible for giving me an excellent working environment and motivation to work. My gratitude to: Wiebke Niether, Flavia Mendes, Stephen Assabere, Taciana Ziembowicz, MarieFrance Hesse, Petra Voigt, Thorsten Zeppenfeld, Luisa Hallmaier-Wacker, Harold Hughes, Barbara von der Lühe, Stefan Erasmi, Anja Södje, Katharina Edelmann, Susanne Schlicht, Jorge Días, Nora Pfaffner, Daniel Wyss, Alexandra Silinski, Ulf Schneidewind, Ammar Emam, Stefan Möller, and many others!

I would like to thank all scientists and technicians that collaborated and participated in activities of the Carbiocial project, specially Gabriele Lamparter, Ricardo Amorim, Kristof Kovacs, Gilmar Nunes, Túlio Santos, Jonas Macedo, Alexandro Kirst, Norma Bertão and Eduardo Couto. It was a fantastic experience!

I also would like to thank the support from the DAAD, the BMBF and the University of Göttingen, which provided me financial and infrastructural assistance for this Ph.D. research. 



\section{Table of Contents}

LIST OF TABLES $\quad$ XV

LIST OF FIGURES XIII

SUMMARY 13

1. GENERAL INTRODUCTION 19

1.1. THESIS OUTLINE 19

1.1.1. Deforestation IN THE Amazon AND CerRado biomes 19

1.2. EFFECTS OF LULC CHANGE ON SOIL PROPERTIES AND WATER AND NUTRIENT FLUXES 24

1.2.1. EFFECTS OF LULC CHANGE ON WATER FLUXES AND SOILS 24

1.2.2. EFFECTS OF LULC ON NUTRIENT FLUXES 26

1.3. RESEARCH CONTEXT, REGIONS AND METHODS 27

1.4. OBJECTIVES AND THESIS STRUCTURE 29

2. INVESTIGATING DISCHARGE AND RAINFALL VARIABILITY IN AN AMAZONIAN WATERSHED: DO ANY TRENDS EXIST?

2.1. INTRODUCTION 34

2.2. STUDY AREA DESCRIPTION

2.3. STUDY METHODOLOGY 36

2.4. RESULTS AND DISCUSSION 37

2.4.1. ANNUAL RAINFALL AND STREAMFLOW 37

2.4.2. DECADAL FLOW DURATION CURVES 38

2.4.3. WAVELET ANALYSIS 38

2.5. CONCLUSIONS 41

3. A MULTI-APPROACH AND MULTI-SCALE STUDY ON WATER QUANTITY AND QUALITY CHANGES IN THE TAPAJÓS RIVER BASIN, AMAZON

3.1. INTRODUCTION 44

3.2. AREA OF STUDY 46

3.3. METHODS $\quad 47$

3.3.1. EXPERIMENTAL MICRO-CATCHMENT STUDY 47

3.3.2. JAMANXIM RIVER BASIN MODELLING

3.3.3. TAPAJÓS RIVER BASIN ANALYSIS

3.4. RESULTS AND DISCUSSION

3.5. CONCLUSIONS 50

4. CHARACTERIZING RAINFALL RUNOFF SIGNATURES FROM MICRO CATCHMENTS WITH CONTRASTING LAND COVER CHARACTERISTICS IN SOUTHERN AMAZONIA

4.1. INTRODUCTION AND OBJECTIVES 53

4.2. STUDY SITE AND METHODS 56

4.2.1. LOCATION AND PhySical ChaRACteRistics 56

4.3. METHODS 58

4.3.1. RAINFALL AND WEATHER DATA 58

4.3.2. CATCHMENT DISCHARGE

4.3.3. SOIL MOISTURE $\quad 60$

4.3.4. HYDROGRAPH SEPARATION

4.3.5. WATER BALANCE 61

4.4. RESULTS AND DISCUSSION 61

4.4.1. PRECIPITATION CHARACTERISTICS 62 
4.4.2. SOIL PROFILE CHARACTERISTICS 62

4.4.3. SOIL MOISTURE VARIATION 64

4.4.4. CATCHMENT DISCHARGE 66

4.4.5. EVAPOTRANSPIRATION

4.5. SUMMARY AND CONCLUSIONS

5. EFFECTS OF CONVERSION OF NATIVE CERRADO VEGETATION TO PASTURE ON SOIL HYDRO-PHYSICAL PROPERTIES, EVAPOTRANSPIRATION AND STREAMFLOW ON THE AMAZONIAN AGRICULTURAL FRONTIER

5.1. INTRODUCTION 76

5.2. METHODS

5.2.1. STUDY AREA DESCRIPTION

5.3. CATCHMENT INSTRUMENTATION, CHARACTERIZATION, AND ANALYSIS 80

5.3.1. TOPOGRAPHIC SURVEY 80

5.3.2. SOIL GEOSTATISTICAL ANALYSIS AND SAMPLING

5.3.3. SOIL PHYSICAL AND HYDRAULIC PROPERTIES 82

5.3.4. RAINFALL AND EVAPOTRANSPIRATION 82

5.3.5. CATCHMENT DISCHARGE AND HYDROGRAPH ANALYSIS 85

5.3.6. STATISTICAL ANALYSES

5.4. RESULTS $\quad 87$

5.4.1. CATCHMENT PHYSIOGRAPHIC ATTRIBUTES 87

5.4.2. SOIL PHYSICAL AND HYDRAULIC PROPERTIES 88

5.4.3. RAINFALL CHARACTERISTICS 91

5.5. DISCUSSION 94

5.6. CONCLUSIONS 96

6. IMPACTS OF LAND-USE AND LAND-COVER CHANGE ON STREAM HYDROCHEMISTRY IN THE CERRADO AND AMAZON BIOMES 100

6.1. INTRODUCTION 100

6.2. STUDY AREA 103

6.3. METHODS 105

6.3.1. SOIL PHYSICAL AND CHEMICAL PROPERTIES 105

6.3.2. WATER SAMPLING DESIGN AND ANALYSIS 106

$\begin{array}{ll}\text { 6.3.3. STREAMFLOW AND CAN OUTPUT FLUXES } & 108\end{array}$

6.3.4. STATISTICAL ANALYSIS 110

6.4. RESULTS 111

6.4.1. SOIL PHYSICAL AND CHEMICAL PROPERTIES

6.4.2. HYDROCHEMISTRY RESULTS 112

6.4.3. HYDROLOGICAL AND CAN OUTPUT FLUXES 113

6.5. DISCUSSION 118

6.5.1. STREAM HYDROCHEMISTRY 118

6.5.2. STREAM CAN OUTPUT FLUXES 120

6.6. CONCLUSIONS 124

7. ECOSYSTEM SERVICES IN THE AMAZON AGRICULTURAL FRONTIER: SEPARATING THE WHEAT FROM THE CHAFF IN A FUNCTIONALLY DIVERSE RIPARIAN ZONE 128

$\begin{array}{lll}\text { 7.1. INTRODUCTION } & 128\end{array}$

7.2. STUDY AREA 131

7.3. METHODS 133

7.3.1. VEGETATION SURVEY 133

7.3.2. SOIL SAMPLING AND ANALYSIS 133

7.3.3. WATER SAMPLING AND ANALYSIS 135

7.3.4. STATISTICAL ANALYSES 136

$\begin{array}{lll}\text { 7.4. RESULTS } & 137\end{array}$ 
7.4.1. RIPARIAN ZONE VEGETATION 137

7.4.2. SOIL HYDRO-PHYSICAL AND CHEMICAL PROPERTIES 138

$\begin{array}{ll}\text { 7.4.3. WATER QUALITY } & 138\end{array}$

7.5. DISCUSSION 141

7.5.1. THE FUNCTIONALLY AND EVOLUTIONARILY DIVERSE PLANT COMMUNITY 141

7.5.2. IMPLICATIONS OF RZ CONSERVATION ON SOIL AND WATER QUALITY 142

7.5.3. UNCERTAINTIES AND RESEARCH DIRECTIONS ON RZ STUDIES IN AGRICULTURAL LANDSCAPE 144

7.6. CONCLUSIONS 146

ACKNOWLEDGEMENTS $\quad 147$

8. CONCLUSIONS AND OUTLOOK 149

REFERENCES $\quad 152$

$\begin{array}{lr}\text { APPENDICES } & 179\end{array}$

$\begin{array}{ll}\text { APPENDIX A } & 179\end{array}$

$\begin{array}{ll}\text { APPENDIX B } & 180\end{array}$

APPENDIX C 181

$\begin{array}{ll}\text { APPENDIX D } & 184\end{array}$ 



\section{List of Figures}

Figure 1.1 Annual deforestation and the area of indigenous territories, sustainable development reserves (e.g., extractive reserves), strict protection reserves, and agrarian reform settlements in the Brazilian Amazon. $\quad 19$ Figure 1.2 Deforestation patterns following the business-as-usual and governance approaches. 20 Figure 1.3 Land-cover classification for the das Mortes River basin in 201. Figure 1.4 Development of pasture areas in the municipalities of the das Mortes River basin in the Cerrado biome area of the state of Mato Grosso. 22 Figure 1.5 a) Land-map cover of 2010 from Mato Grosso and Pará states, and b) Satellite images from the Novo Progresso area. 23 Figure 1.6 Schematic representation of the global hydrological cycle. 24 Figure 1.7 Carbiocial study areas in the Cerrado and Amazon biomes along the BR-163. 29 Figure 1.8 Study areas. $\quad 30$ Figure 2.1 Upper Rio das Mortes watershed in central Mato Grosso State, Brazil. 36 Figure 2.2 Mann-Kendall test on (a) annual rainfall in the study watershed, (b) the mean annual streamflows, and (c) 7-day low flows recorded at ANA 26050000 gauging station. 37 Figure 2.3 Decadal flow duration curves for stream flow measured at the ANA station 26050000 for the period 1968-2007.

Figure 2.4 (a) Daily streamflow at Araguaia gauge for the 1967-2007 period. (b) The wavelet power spectrum using Morlet mother wavelet. The thick contour encloses regions of greater than $95 \%$ confidence for a red-noise process with a coefficient of 0.99158. (c) The global wavelet power spectrum. The dashed line is the $5 \%$ significance level for the global wavelet spectrum, using a red-noise background spectrum. (d) Scale-average wavelet power over the 256-512-day band. The dashed line is also the 95\% confidence level assuming red-noise. 40 Figure 3.1 Area of study. 46 Figure 3.2 (a) Land-use distribution in 2011, and (b) Land-use scenario (22\% of deforestation) for the year 2030 following a business as usual approach (Göpel \& Schaldach, 2016). 48 Figure 3.3 Streamflow and rainfall in the forest and pasture micro-catchments. 48 Figure 3.4 Calibration and validation with land-use update for the Jamanxim catchment. 49 Figure 3.5 Nitrate and total dissolved carbon fluxes. 49 Figure 4.1 Study area location and study catchments instrumentation. 56 Figure 4.2 Typical soil profiles in the two study catchments. 58 Figure 4.3 Daily rainfall in the two study catchments (average of the tipping buckets). 63 Figure 4.4 Correlation between daily rainfall data from Forest and Pasture catchments 63 Figure 4.5 Time series of soil moisture. Figure 4.6 Peak discharges and areal average rainfall in the study catchments. $\quad 67$ Figure 4.7 Normalised discharges and areal average rainfall in the study catchments. 68 Figure 4.8 Flow duration curves for daily discharge data from the study catchments. 69 Figure 4.9 Example storm hydrographs from the two catchments. 71 Figure 4.10 Daily Evapotranspiration and areal average rainfall for the study catchments. 72 Figure 5.1 Overview of the Amazon and Cerrado biomes, the deforestation extension in the Legal Amazon, and the location of the cerrado and pasture catchments. $\quad 79$

Figure 5.2 Slope, soil sampling points, and Compound Topographic Index (CTI). 87

Figure 5.3 Scatter-plot matrix of soil properties values in the gallery forest (upper panel) and PLU (lower panel) areas in the cerrado and pasture catchments. 90 Figure 5.4 Boxplot of the $\mathrm{K}_{\text {sat }}$ results, and the $50^{\text {th }}$ and $90^{\text {th }}$ percentiles of the rainfall intensity in the cerrado and pasture catchments.

Figure 5.5 Monthly rainfall per catchment.

Figure 5.6 10-day moving average of evapotranspiration, and daily areal average rainfall for the cerrado and pasture catchments.

Figure 5.7 Daily discharges and areal average rainfall for the cerrado and pasture catchments. 
Figure 5.8 Flow-duration curves of daily discharge for the cerrado and pasture catchments.

Figure 6.2 Biplots of the PCAs after varimax rotation for the first (C1) and second (C2) components of the: a) Amazon catchments base streamflow ( $\left.\mathrm{S}_{\mathrm{b}}\right)$; b) Amazon catchments storm streamflow $\left(\mathrm{S}_{\mathrm{s}}\right)$; c)

Cerrado catchments base streamflow $\left(S_{b}\right)$; and d) Cerrado storm strea streamflow $\left(S_{s}\right)$.

Figure 6.3 Boxplot and violin plots of non-flow weighted carbon and nitrogen concentrations in base streamflow and storm streamflow.

Figure 6.4 Boxplot and violin plots of $\mathrm{NO}_{3}, \mathrm{Ca}$ and $\mathrm{K}$ non-flow weighted concentrations in base streamflow and storm streamflow.

Figure 6.5 Annual carbon and nutrient output fluxes of base streamflow $\left(\mathrm{S}_{\mathrm{b}}\right)$ and storm streamflow $\left(\mathrm{S}_{\mathrm{s}}\right)$.

Figure 7.1 Study area location.

Figure 7.2 (a) Assembly and phytogeographic distribution of the surveyed plant species along the plots; (b) Percentage of the represented phytogeographic domains according to the two vegetation formations in $R Z$ transect. Outer circle represents gallery forest (plots 1-4) and inner circle campo de murundus (plots 5-8).

Figure 7.3 Boxplot of water quality parameters throughout the study are in different hydrological pathways. 


\section{List of Tables}

Table 1.1 Contradictory results: ecosystem processes changes due to deforestation in the Amazon 26

Table 2.1 Decadal low, medium and high stream flows derived from flow duration curves. 38

Table 3.1 Q results with SWAT for the land-use distribution and scenario. 49

Table 4.1 Soil horizon characteristics in the study catchments 57

Table 4.2 Saturated Hydraulic conductivity $(\mathrm{cm} / \mathrm{hr})$ measured at two depths and three different

positions in the study catchments.

Table 4.3 Hydrological analysis and indices for the study catchments derived from rainfall runoff data

for the period January to May 2013.

Table 4.4 Results from a mass balance.

Table 5.1 Satellite scenes description, weather data, and ETrF values. 85

Table 5.2 Summary of catchments' physical and topographic characteristics. 88

Table 5.3 Summary of the soil properties.

Table 5.4 Total streamflow and hydrological indices. 93

Table 5.5 Daily and annual evapotranspiration and streamflow rates. 95

Table 6.1 Main characteristics of the catchments. 106

Table 6.2 Mean, one standard deviation and $\mathrm{n}$ of soil physical properties, and $\mathrm{C}$ and $\mathrm{N}$ contents. 111

Table 6.3 Correlations between variables and components after varimax rotation. 114

Table 6.4 Base streamflow, storm streamflow and total streamflow ratios of stream output fluxes for

each pair of catchments. $\quad 121$

Table 6.5 Percentage ratio of the storm streamflow duration, volume and fluxes to the total

streamflow. $\quad 123$

Table 7.1 Soil hydro-physical properties.

Table 7.2 Mean, one standard deviation and sample size (n) of soil chemical properties. 139 



\section{SUMMARY}

On many levels, there is a lack of understanding regarding the impacts of deforestation on water resources and soil properties in the Amazon-Cerrado ecotone, where the Amazonian agricultural frontier is mostly present. Both the large spatial extent of this region and the wide diversity of environmental conditions requires extensive fieldbased data collection to allow comprehensive process characterization and to improve hydrological modelling parameterization. Furthermore, the Cerrado biome, where most of the deforestation in this region has occurred, is often not integrated into the studies regarding the Amazon deforestation.

To contribute to fill this knowledge gap, I, in the context of the CarBioCial project (Gerold, 2017), conducted several hydrological and soil analyses in areas of Southern Amazonia that have been rapidly deforested. To that end, two macro-catchments were selected, one in the Amazon biome (Jamanxim River basin, 37,403 $\mathrm{km}^{2}$ ) and one in the Cerrado biome (das Mortes River basin, 17,556 km²), both located on the Amazon agricultural frontier. In both the das Mortes and the Jamanxim River basins, paired micro-catchments under different land use and land cover, i.e., native vegetation (rainforest or cerrado vegetation) vs. pasture for extensive cattle ranching, and a cropland area were selected to characterize the changes in hydrology and soil hydrophysical properties due to these contrasting land uses. The general objectives of this $\mathrm{PhD}$ research were to: a) analyze trends in discharge and water quality in streams of macro-catchments in the Amazon and Cerrado biomes; b) determine soil hydrophysical properties and quantify streamflow and evapotranspiration from adjacent micro-catchments whose major difference is the LULC; c) quantify stream CAN concentrations and output fluxes during prevalent baseflow and stormflow conditions to improve the understanding of carbon and nutrient drivers in low-order streams; d) assess the soil hydro-physical and chemical properties, as well as water quality of cropland and riparian vegetation areas of a catchment in a typical large-scale commercial cropland system. 
The analyses showed that land-use and land-cover change alters water quantity of large rivers in the Amazon and Cerrado biomes. These changes are more pronounced as an increase in the low flows, which are mainly maintained by hundreds of small streams that have baseflow as a dominant discharge condition. In these small catchments, catchment physiographic parameters play an essential role in the hydrological responses in both Amazon and Cerrado biomes, and the native vegetation conversion into pastures substantially change the water balance of these catchments. This proved to drive an increase in the baseflow in low-order streams. The changes due to soil hydro-physical degradation (e.g., increased bulk density and reduced soil porosity) cause increases in short-lived events as peak flows, as observed in the pasture catchment in the Amazon biome. The decrease of evapotranspiration is also another critical driver in the water balance in this region, because pastures could not maintain evapotranspiration rates as high as the native vegetation. All these changes are connected to other aspects of the environment. As this thesis shows, the difference in the hydrological fluxes increases the carbon and nutrient fluxes. In this context, the stormflow is a substantial hydrological pathway for carbon and nutrient losses, especially in areas where rainfall intensities exceed the infiltration capacity rates. On account of these impacts, the conservation of riparian zones appears to be one of the land management strategies that will mitigate further implications in the hydrochemistry of rivers. This study indicates that, indeed, riparian zones have a complex ecosystem of plants and soil properties that directly improve the water quality of flows towards the streams. However, the long-term implications of deforestation in the Amazon and Cerrado in these riparian zones are still unknown.

This Ph.D. research connects several themes under discussion regarding the environmental changes in the Amazon and Cerrado biomes. The outcomes of this thesis provide solid research directions for further studies in these biomes, which should focus on the subsurface water flows and the role of the fragmented vegetation patches, such as the riparian zones, in these regions. 


\section{General Introduction}

\subsection{Thesis outline}

\subsubsection{Deforestation in the Amazon and Cerrado biomes}

Land use and land cover (LULC) changes have been one of the main factors impacting ecosystem services, such as adequate soil and water quality, provided by forests around the world (Vose et al., 2011; Gharibreza et al., 2013; Crossman et al., 2014; Ghimire et al., 2014; Li et al., 2014). The Amazon biome has been massively deforested for decades since the 1990s (Fig. 1.1), with subsequent expansion of largescale commercial cropping systems and establishing with the Cerrado biome, i.e., on the Amazon-Cerrado ecotone, the largest zone of agricultural expansion on earth (Neill et al., 2017).

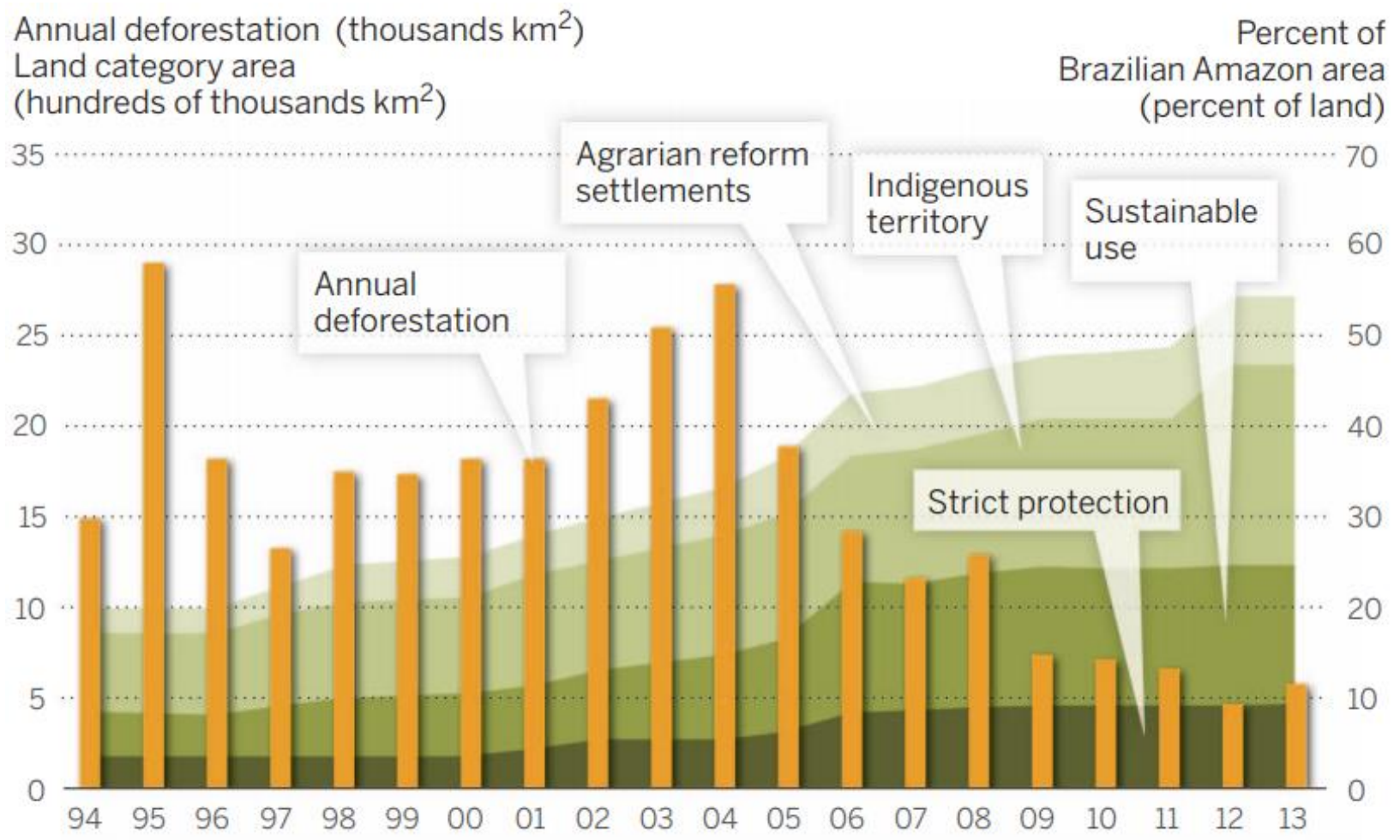

Figure 1.1 Annual deforestation and the area of indigenous territories, sustainable development reserves (e.g., extractive reserves), strict protection reserves, and agrarian reform settlements in the Brazilian Amazon (source: Nepstad et al., 2014). 


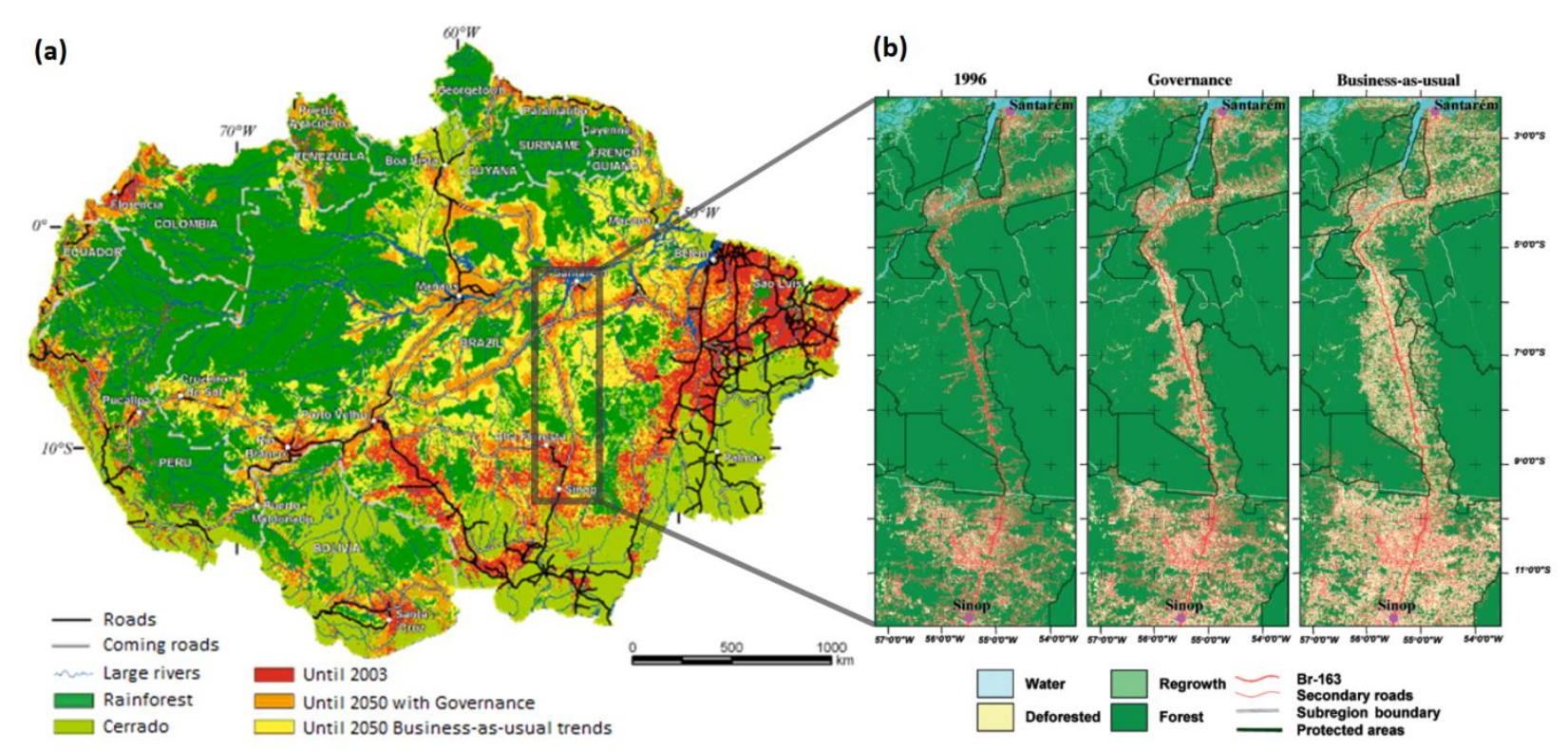

Figure 1.2 Deforestation patterns following the business-as-usual and governance approaches: a) for the Amazon basin (adapted from Soares-Filho et al., 2005), and b) for the BR-163 from Sinop (Mato Grosso) to Santarém (Pará) (Adapted from Soares-Filho et al., 2004)

The establishment of road networks is one of the main drivers of deforestation in the Amazon (Jusys, 2016; Pinheiro et al., 2016; Gollnow et al., 2017). These roads allow colonists and farmers increasing access to forests, which leads to the expansion of industrial logging, mining and agriculture (Laurance, 2001). To illustrate this, Fig. 1.2a compares the LULC status in 1996 with scenarios of deforestation that consider the historical socio-economical patterns (named as business-as-usual scenario) and where advances in environmental regulation, support for sustainable land-use systems and planning (referred to as governance scenario) are also taken into account. It shows that the development of roads is still a lead pathway to LULC changes in the Amazon. In this context, the national highway, BR-163, has an important role in leading these changes. The BR-163 highway connects Cuiabá, in the Mato Grosso state, to Santarém, in the Pará state, close to the Amazon River (Fig. $1.2 \mathrm{~b})$, and provides farmers in areas along this highway with access to the international port of Santarém (Fearnside, 2007). Although the BR-163 is not entirely paved, the Brazilian government has prioritized the paving of this road in order to turn the port of Santarém into a major soybean exportation facility (Carvalho et al., 2002), reducing the total of over $1,000 \mathrm{~km}$ of unpaved segments to less than $100 \mathrm{~km}$ during the last 15 years (Soares-Filho et al., 2004a; Canal Rural, 2017). 
Although environmental research in Brazil has focused on the Amazon biome, most of deforestation and agricultural expansion in Brazil has occurred in the Cerrado biome, a biodiversity hotspot for conservation comprises dry forests, woodland savannas, and grasslands (Myers et al., 2000; Spera et al., 2016). The conversion of natural cerrado vegetation to crops and pastures since the 1970 s has removed $50 \%$ of the original 2 million $\mathrm{km}^{2}$ of the native vegetation in this biome. This is greater than the rainforest loss in the Amazon biome (Klink and Machado, 2005; Lambin et al., 2013). To illustrate how LULC has changed in this biome, Fig. 1.3 shows the landcover classification of the das Mortes River basin (ca. 18,000 km²) located in the Cerrado portion of Amazonian agricultural frontier in Mato Grosso. In this basin, croplands and pastures occupied approximately 75\% of the total area in 2011 (Müller et al., 2015).

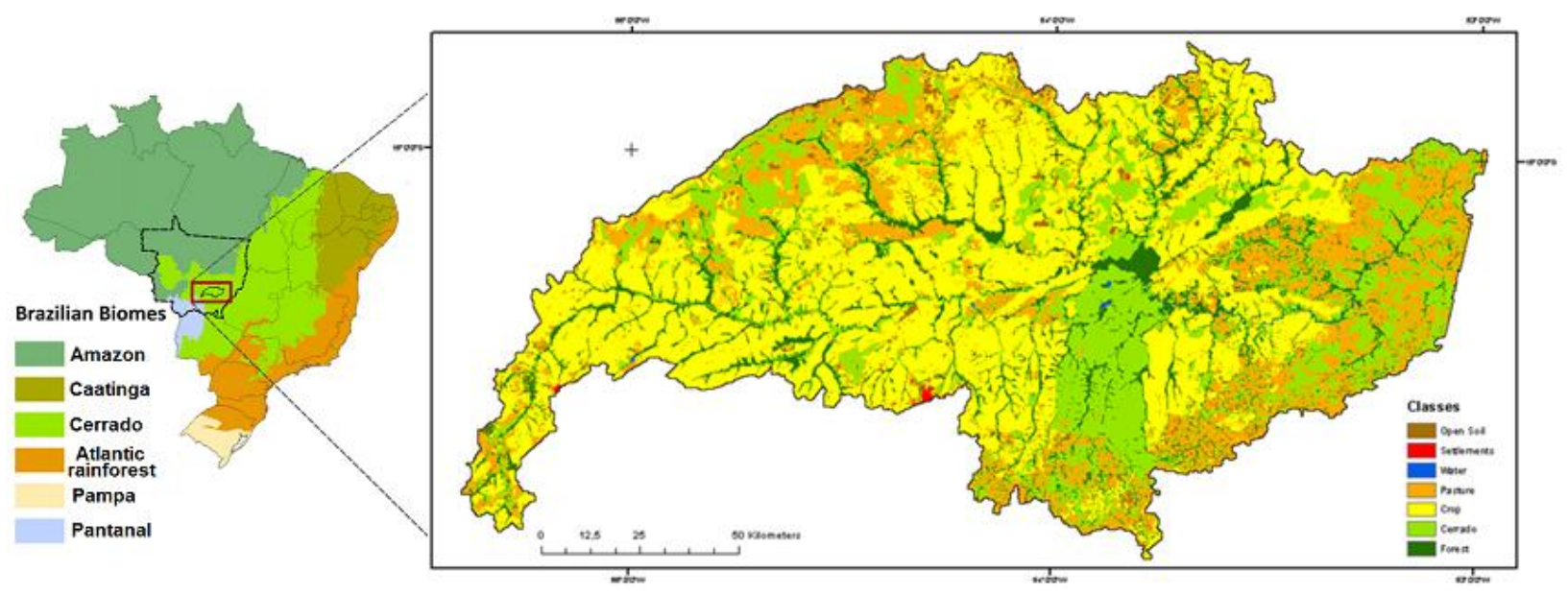

Figure 1.3 Land-cover classification for the das Mortes River basin in 2011 (Adapted from Müller et al., 2015).

Although Müller et al. (2015) show that most of the das Mortes River basin is occupied by croplands $(51 \%)$, the conversion of cerrado vegetation to pastures had been the leading cause of deforestation until the beginning of the 1990s. Over time these pastures are often replaced by cash crop systems (Barona et al., 2010; Cohn et al., 2016) or are abandoned due to the decrease of grass productivity, reaching advanced stages of degradation (Davidson et al., 2012). Based on the records of the Brazilian Institute of Geography and Statistics (IBGE), Fig. 1.4 shows the development of the total area of the das Mortes River basin used for pastures from 1974 to 2011. The area of pastures increased from ca. $1,800 \mathrm{~km}^{2}$ in 1985 to ca. $4,500 \mathrm{~km}^{2}$ in 1990 , and 
remained relatively stable, reaching $5,400 \mathrm{~km}^{2}$ in 2011 , while the total area for croplands continuously increased from $2,595 \mathrm{~km}^{2}$ in 1990 to $8,312 \mathrm{~km}^{2}$ in 2011 (SIDRA/IBGE, 2012).

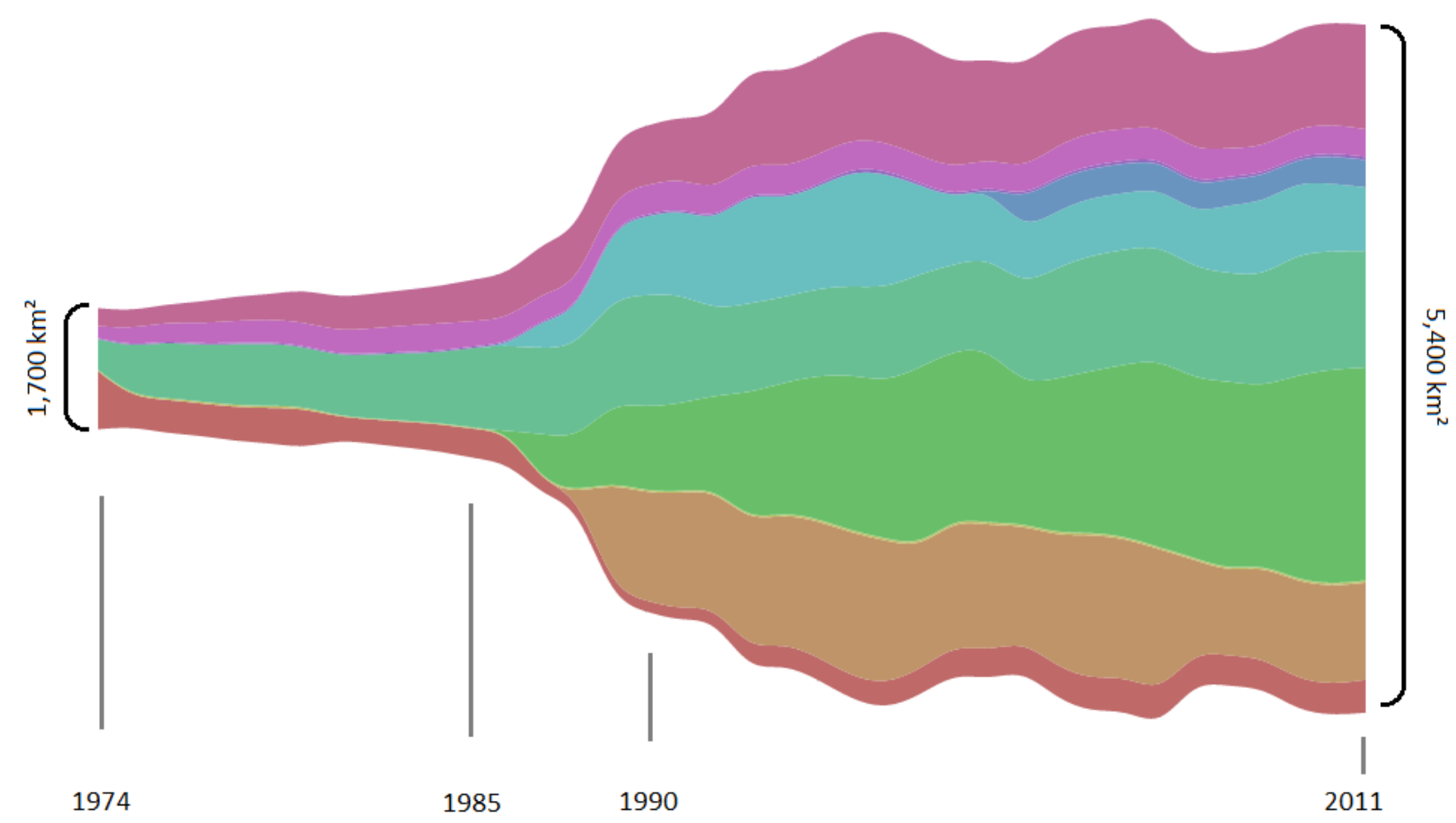

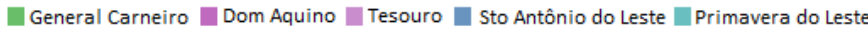

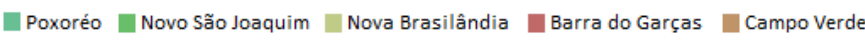

Figure 1.4 Development of pasture areas in the municipalities of the das Mortes River basin in the Cerrado biome area of the state of Mato Grosso. The area of pastures was quantified using the number of cattle in each municipality (proportional to their area within the River basin) and the area used per cattle unit provided by SIDRA/IBGE (2012b)

Rufin et al. (2015) and Gollnow et al. (2017) have shown that the same pattern of conversion of native cerrado vegetation to grassland pastures that caused wellestablished agro-industrial areas in the Brazilian Cerrado to exist is being established since the 2000s in the Amazon biome. Figure 1.5a shows the land-cover in areas along the BR-163 highway in 2010 between Sinop and Novo Progresso. The Mato Grosso domain of Fig 1.5a (Sinop-Guarantã do Norte) shows a great deforestation with a substantial presence of pastures and croplands in the South portion, whereas the Pará domain (between Guarantã do Norte and Parque Nacional do Jamaxim) has a still higher proportion of land cover under forest and no significant croplands. Figure $1.5 \mathrm{~b}$ shows the development of deforestation in the region of Novo Progresso from 2000 to 2016. Novo Progresso, which is one of the areas of study in this thesis, is 
considered a hotspot of deforestation in the Amazon biome mainly because of the increase of deforestation for logging and pasture activities in the past years (Pinheiro et al., 2016). This intensification of agricultural activities at the expense of natural forest in this region of the Amazon biome is turning this area into the fastest-growing agricultural frontier in the world (Brando et al., 2013; Nobre et al., 2016).

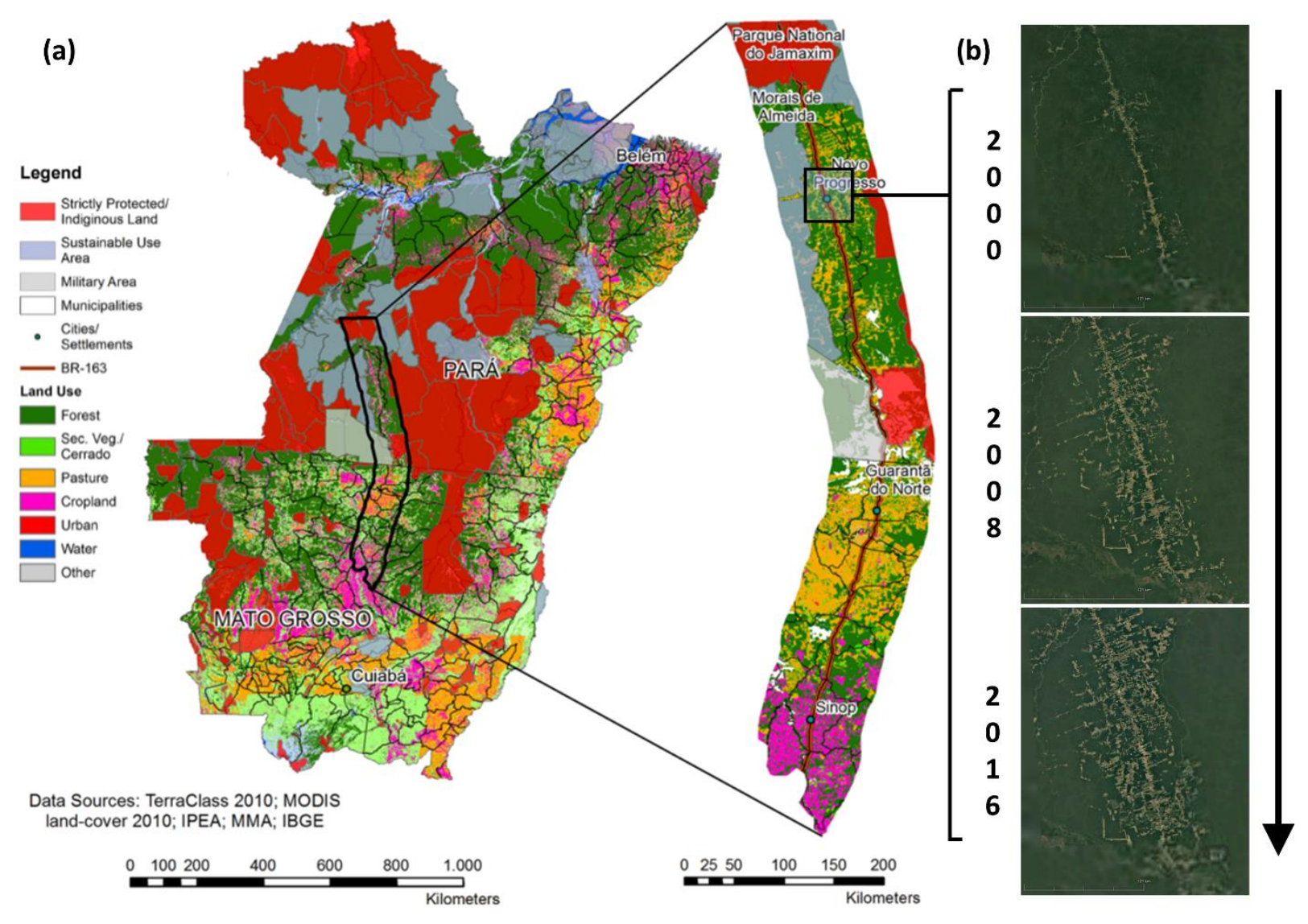

Figure 1.5 a) Land-map cover of 2010 from Mato Grosso and Pará states with an emphasis on the BR-163 between Sinop and Novo Progresso municipalities (Gollnow et al., 2017), and b) Satellite (Landsat 7) images from the Novo Progresso area from 2000 to 2016. 
1.2. Effects of LULC change on soil properties and water and nutrient fluxes

1.2.1. Effects of LULC change on water fluxes and soils

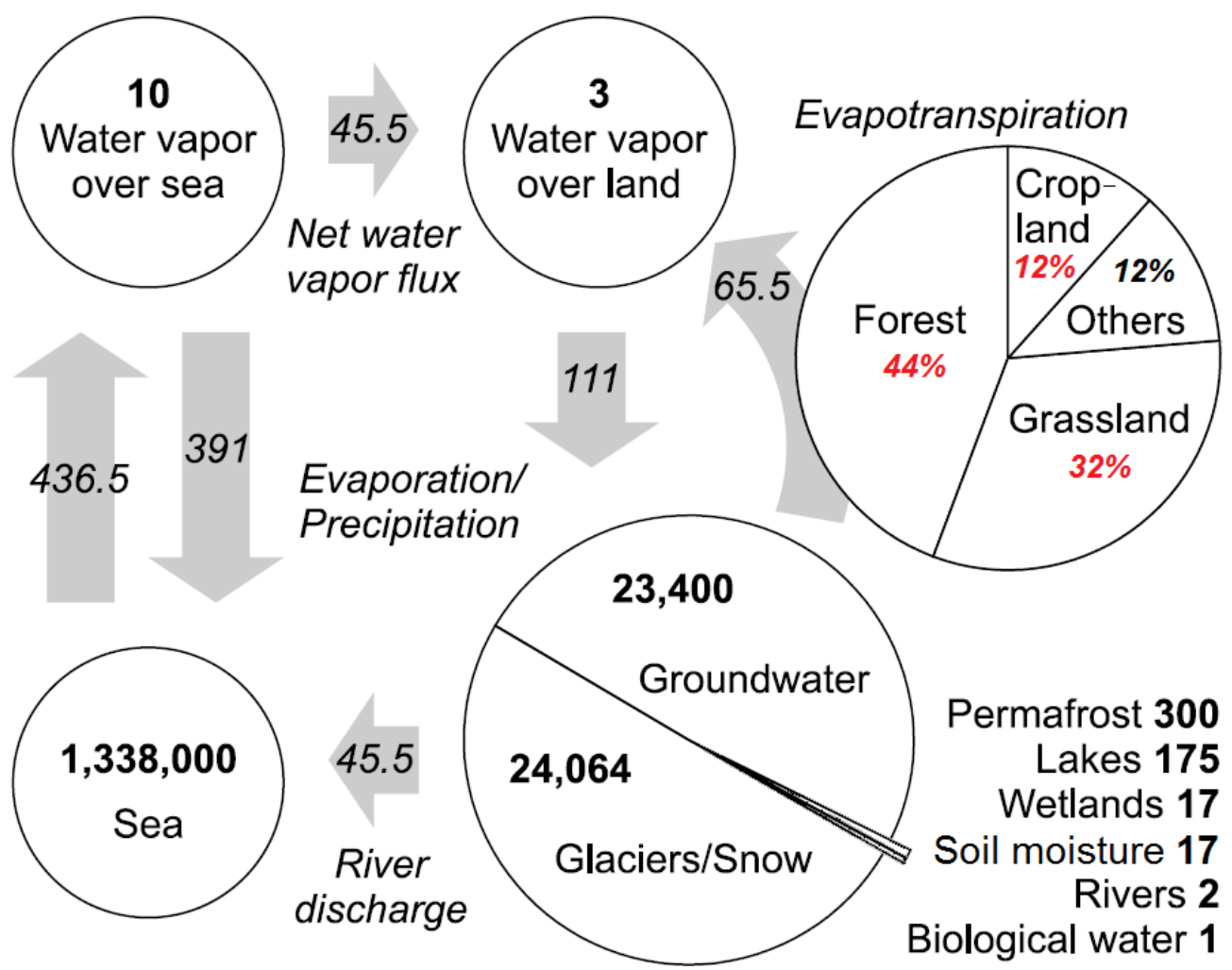

Figure 1.6 Schematic representation of the global hydrological cycle (excluding Antarctica) with the storages (in bold and $\mathrm{km}^{3}$ ) and fluxes (in italic and $\mathrm{km}^{3} \mathrm{y}^{-1}$ ). Adapted from Teuling (2007) with data from Oki and Kanae (2006).

Forests play a major role in the global hydrological cycle (Fig. 1.6) as they are responsible for almost half of the total evapotranspiration (ET) (Oki and Kanae, 2006). Reduction of forest cover is unbalancing the ET contribution across spatial scales, and this has implications in other hydrological components such as streamflow and groundwater recharge (Neu et al., 2011; Richey et al., 2011; Oliveira et al., 2015). Guimberteau et al. (2017) showed LULC change scenarios for the Amazon indicating that by the end of this century the total forested area of the Amazon Basin will have decreased between 7 and 34\%. The most severe forest clearing will occur in Southern Amazonia, with the Madeira, Xingu and Tapajós River basins experiencing a 50\% decrease in forest cover area. They also show that pastures and croplands do not sustain evapotranspiration rates as forests, and that deforestation in the Amazon will 
lead to an increase in baseflows - also demonstrated by Lamparter et al. (2016) in the Tapajós River basin — by the end of this century.

Forest clearing in the Amazon also causes soil changes (Zimmermann et al., 2006; Neill et al., 2008), as the soil compaction is induced by land use after deforestation, which in turn increases bulk density and reduces infiltration rates and hydraulic conductivity mainly by pasture land use (Martínez et al., 2004; Scheffler et al., 2011; Hunke et al., 2015b). Further research could provide insight into the relationship of stormflow volume increase due to LULC change on different soils and at different scales (Germer et al., 2010). The magnitude and duration of LULC change effects on base and peak flows depend on several catchment characteristics such as soils, morphology, and geology of the catchment, as well as climate conditions, including rainfall patterns (Birkinshaw et al., 2010). Time series records of hydroclimatic variables such as precipitation and streamflow have been widely used to support detection of trends (or lack thereof) in catchments (Burn et al., 2010; Esterby, 1996; Fu et al., 2010; Halliday et al., 2012; Oliveira et al., 2014). In many parts of the world, several large-scale analyses of such trends have been conducted on precipitation and streamflow data at different time scales, which is not the case for the South American continent, where analyses of trends in instrumental records of streamflow and precipitation are scarce (Guzha et al., 2013a).

The impacts of LULC changes in the water balance are also scale-dependent (Gerold, 2011; Lima et al., 2014). Although some studies on meso- to macro-scale catchments have shown that deforestation causes an increase in annual streamflows (e.g., Costa et al. (2003), Chappell and Tych (2012) and Dias et al. (2015), Awotwi et al. (2015) observed streamflow reductions and Wilk et al. (2001) were unable to detect any change in hydrological fluxes, i.e., base and peak flows, in a watershed with substantial deforestation. These contrasting results are exemplified in Table 1.1 and could be attributed to differences in climate, topography, morphology, soil properties and differences in land cover types and sizes of each catchment (Guzha et al., 2014). Studies using small watersheds are usually more prone to detect hydrological changes due to LULC changes than macro-scale approaches (Jepson, 2005; Oliveira et al., 2014). 
Table 1.1 Contradictory results: ecosystem processes changes due to deforestation in the Amazon (source: Gerold (2017)).

\begin{tabular}{ccc}
\hline Ecosystem processes & Negative consequence & No change or positive \\
\hline $\begin{array}{c}\text { Climate change and } \\
\text { rainfall trends }\end{array}$ & $\begin{array}{c}\text { Increasing droughts and } \\
\text { decreasing rainfall }\end{array}$ & $\begin{array}{c}\text { Until 60\% deforestation } \\
\text { no rainfall decreases; } \\
\text { increase of rainfall over } \\
\text { large forest patches }\end{array}$ \\
\hline $\begin{array}{c}\text { River discharge and } \\
\text { water stress }\end{array}$ & $\begin{array}{c}\text { Increasing discharge and } \\
\text { flood risk }\end{array}$ & $\begin{array}{c}\text { Decreasing discharge } \\
\text { with reduced regional P }\end{array}$ \\
\hline C-stocks and GHG & $\begin{array}{c}\text { Large scale forest } \\
\text { disturbance with 15-26 } \\
\text { Pg C-emissions next 20 } \\
\text { years }\end{array}$ & $\begin{array}{c}\text { All protected areas can } \\
\text { avoid 5.8-10.8 Pg C- } \\
\text { emissions until 2050 }\end{array}$ \\
\hline
\end{tabular}

\subsubsection{Effects of LULC on nutrient fluxes}

In addition to understanding the impacts of LULC changes on hydrological regimes, it is also fundamental to comprehend how the LULC changes influence the hydrochemistry processes in environments such as pristine catchments undergoing anthropogenic changes (Jordan et al., 1997; Neill et al., 2013). In the past years, projects such as Large-Scale Biosphere-Atmosphere Experiment (Lahsen and Nobre, 2007), CLIM-AMAZON (http://www.clim-amazon.eu/) and ANACONDAS/ROCA (Satinsky et al., 2014), have profoundly contributed to the scientific awareness of the Amazon environment. Despite these scientific efforts, the understanding of deforestation impacts on the water quality in the Brazilian Amazon is still scarce.

It is widely known that surface water plays a substantial role in the $C$ balance in the Amazon region (Moreira-Turcq et al., 2003; Waterloo et al., 2006; Neu et al., 2011; Richey et al., 2011). Therefore, it is important to quantify the impacts of LULC changes in streamflow carbon and nutrient (CAN) fluxes. To that end, research has often focused on identifying the impacts of the conversion of forests into pastures (Thomas et al., 2004; Neill et al., 2011; Silva et al., 2011), and just a few have quantified the importance of water pathways in CAN fluxes in this region (e.g., Biggs et al. (2006), Johnson et al. (2006), Germer et al. (2009)). Figueiredo et al. (2010) and Silva et al. (2007) have shown that LULC change alters CAN fluxes in the Amazon and Cerrado biomes. In more detailed studies, Johnson et al. (2006) showed that DOC comprised ca. $60 \%$ of the annual total organic C export and Germer et al. (2009) reported 
quickflow contributions as being responsible for $50 \%$ of the total $\mathrm{K}$ and $\mathrm{Ca}$ stream fluxes, which shows the relevance of studies with high-temporal resolution in order to better quantify CAN fluxes in streams in the Amazon. Although sampling on a day-ofweek basis is usually adopted to estimate nutrient fluxes (Smith et al., 2001), it frequently underestimates nutrient fluxes, because storm events are often more relevant for this type of studies (Tang et al., 2008). Currently, the collection of information in such temporal scale is facilitated by the use of instruments that gives the potential to develop our understanding of nutrient dynamics (Halliday et al., 2015), which have significantly enhanced our ability to monitor CAN fluxes in streams (Blaen et al., 2016).

Although the few studies on the effects of the LULC change in the Amazon on water hydrochemistry have shown some degree of impact, there is limited information on impacts of conversion of LULC to large-scale commercial cropping systems. Neill et al. (2017) have found that streamwater chemistry remained largely unchanged in a large-scale commercial cropping region in the Amazon region. Modern agricultural practices used in this region, i.e., precision farming and no-till cropping processes, have been reported as a land use management approach with low environmental impact (Bongiovanni and Lowenberg-Deboer, 2004; Bramley et al., 2008; Jenrich, 2011). However, it is believed that the riparian vegetation, whose conservation is regulated by federal law, is important in keeping ecosystem services, such as water quality, in croplands of the Amazon region (Soares-Filho et al., 2006; Hunke et al., 2015a). Nevertheless, there is a substantial lack of assessments of Amazonian riparian vegetation zones' characteristics (e.g. plant diversity, soils, and water fluxes) that may have a direct relation to the function of riparian zones as buffers of LULC change impacts on stream water quality.

\subsection{Research context, regions and methods}

This thesis is a result of a collaborative research project (www.carbiocial.de, Gerold (2017) funded by the German Federal Ministry for Education and Research (BMBF) that aimed to investigate viable carbon-optimized land management strategies for maintaining ecosystem services under LULC and climate changes conditions in the 
Southern Amazon, a region that comprises the Amazon-Cerrado ecotone. The Carbiocial project focused on three study areas along the BR-163 (Fig. 1.7). The results in the thesis are related to Carbiocial's Subproject 01 (SP01), which aimed to quantify impacts of human-induced LULC change on soil properties and in water and nutrient fluxes in the Carbiocial's study areas 1 (Cuiabá) and 3 (Southern Pará) (Fig. 1.7). In the surroundings of Cuiabá, the main agricultural colonization of the southern Amazon happened during 1975-1990, and has ever since pushed northwards. It reached the area of Sinop during the 1990s and recently southern Pará, not more than two decades ago. Central Mato Grosso today is a highly industrialized area, with largescale soybean, cotton, and maize production, while Northern Mato Grosso still exhibits a major fraction of intensive cattle farming on pasture. The pioneers at Southern Pará only recently started extensive cattle farming, which replaces timber logging as another substantial income source. Crop production is limited to very few examples. The BR-163 is a prominent illustration of all sorts of problems afflicted with pioneer front development in the Amazon (Brando et al., 2013), while continuously being paved northwards to link the soy and cotton production region in Northern Mato Grosso with the export harbor of Santarém.

For this thesis, two macro-catchments (Jamaxim and das Mortes River basins) for macro-scale analysis and, within these macro-catchments, five micro-catchments under contrasting land use and land cover (one with rainforest, one with cerrado vegetation, two with pasture and one with cropland) for space-for-time analysis were selected. The micro-catchments were instrumented in the dry season of 2012 and monitored until end of 2014. The instrumentation comprised weirs, multiparameter probes, direct and throughfall rain gauges, weather stations, automatic water samplers, deep access tubes for soil moisture measurements and overflow detectors. Additionally, the characterization of these areas included topographic and botanical surveys, soil sampling and analyses, and remote sensing data acquisition. These data were used to apply state-of-the-art methods (e.g., hydrological modelling, remote sensing techniques, high-temporal-resolution water quality analyses, and ecosystem integrated assessments, such as soil-plant-water interactions). 


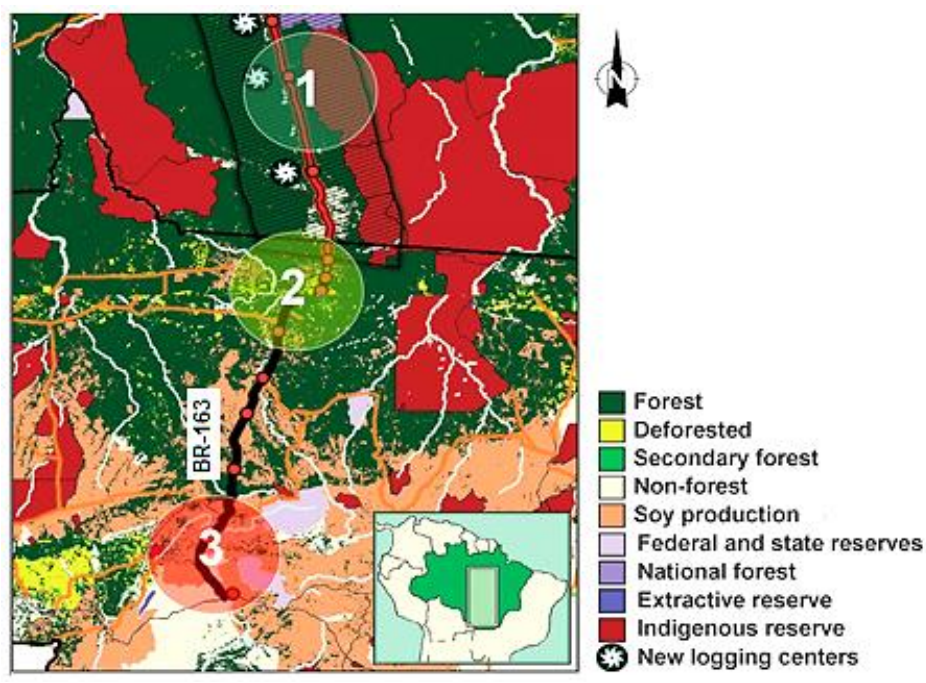

Figure 1.7 Carbiocial study areas in the Cerrado and Amazon biomes along the BR-163: (1) Novo Progresso (Southern Pará); (2) Sinop (Northern Mato Grosso); and (3) Cuiabá (Central Mato Grosso) (Source: www.carbiocial.de).

\subsection{Objectives and thesis structure}

The central hypothesis of this thesis is that forest clearing for pastures in active deforestation zones of Amazon and Cerrado biomes leads to soil hydro-physical degradation and changes stream discharge, evapotranspiration, and CAN fluxes. , and that despite modern agricultural approaches, i.e. no-till and precision farming, that are often associated with low environmental impacts, the conservation of native riparian vegetation within cropland areas is still crucial to keep the minimum ecosystem services, i.e. water and soil quality, in this region.

Based on the central hypothesis, the objectives of this thesis were to: a) analyze trends in discharge and water quality in streams of macro-catchments in the Amazon and Cerrado biomes; b) determine soil hydro-physical properties and quantify streamflow and evapotranspiration from adjacent micro-catchments whose major difference is the LULC; c) quantify stream CAN concentrations and output fluxes during baseflow and stormflow prevalent conditions to improve the understanding of CAN drivers in loworder streams; d) assess the soil hydro-physical and chemical properties, as well as water quality of cropland and riparian vegetation areas of a catchment in a typical large-scale commercial cropland system. These objectives were achieved through six scientific manuscripts, which addressed the thesis hypothesis by using two macrocatchments and five micro-catchments as study areas (Fig. 1.8). 


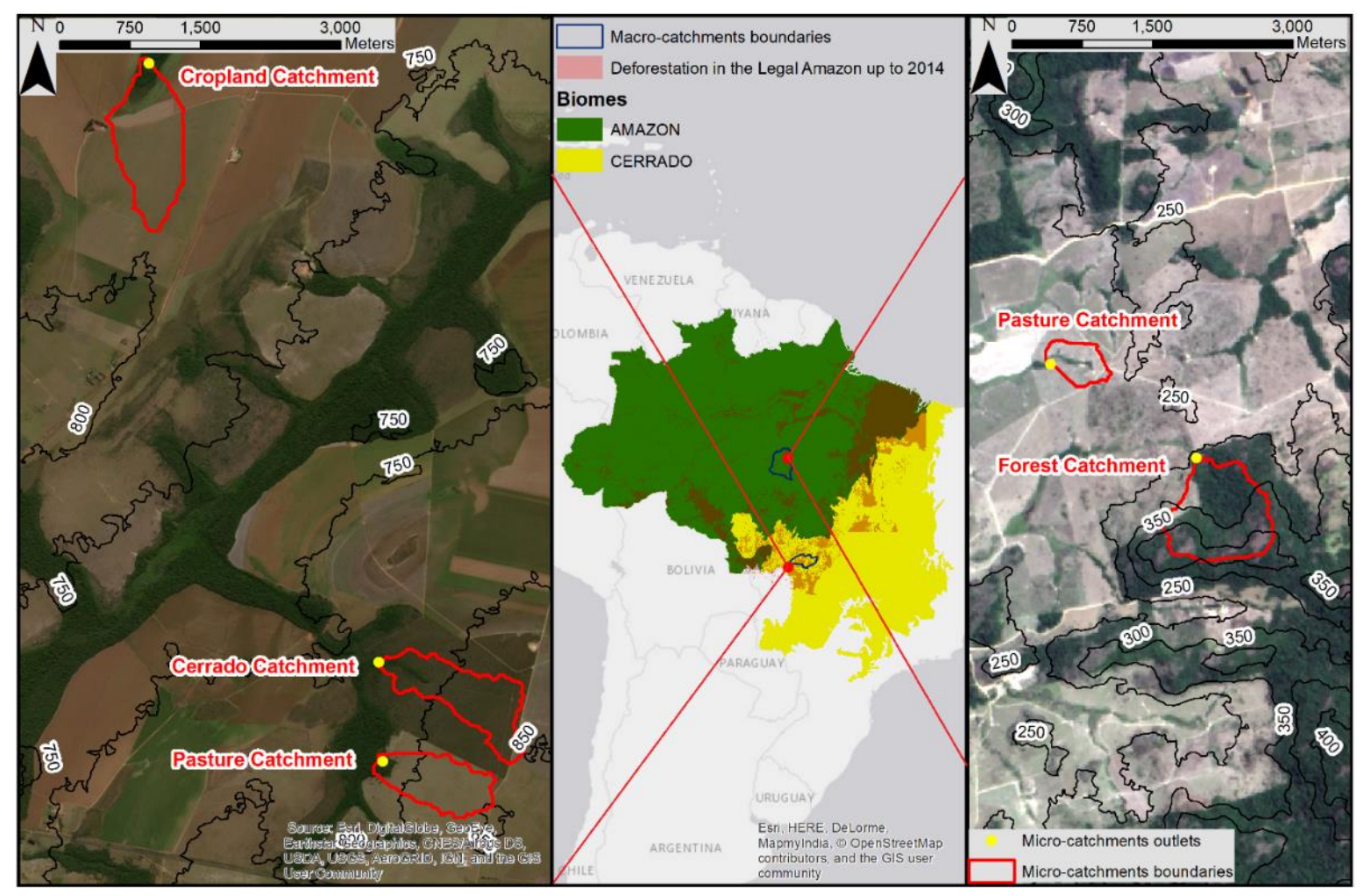

Figure 1.8 Study areas.

To address the objectives, chapters 2 through 7 of this thesis are structured as follows:

- Chapters 2 and 3 show trend analyses of the water quantity and quality at macro-catchment scales in the Cerrado and Amazon biome domains of the Amazon Agricultural Frontier, respectively. Chapter 3 also considers the changes in water quantity in smaller spatial scales of the Amazon biome. These results are used as an overview of the impacts of LULC change on the hydrological and hydrochemistry dynamics in this region;

- Chapters 4 and 5 show the results of the hydrological and soil analyses in four selected micro-catchments under contrasting land-use and land-cover in the Amazon and Cerrado biomes, respectively. These analyses quantify hydrological fluxes in each catchment and show how the LULC change impact hydrological signatures and soil hydro-physical properties;

- Chapter 6 compiles the hydrochemistry results of the 4 catchments described in chapters 4 and 5 . By using the water fluxes from chapters 4 and 5 , it was possible to quantify the CAN fluxes from each of these micro-catchments; 
- Chapter 7 focuses on a cropland catchment located on the Amazon Agricultural Frontier, in the Cerrado biome domain. While the other chapters focus on the LULC change of native vegetation into pasture landscapes, this chapter shows an assessment of the water and soil quality of an agricultural catchment with riparian vegetation preserved, which is another major LULC in the region. This chapter also assesses the ecosystem services provided by this protected area. This catchment differs from the other studied catchments due to its soil with high clay content and low sloppiness. In this cropland catchment, the techniques and analyses used in chapters 4, 5, and 6 were applied. Additionally, in this catchment, analyses of overflow and groundwater quality were performed in combination with a vegetation characterization. 


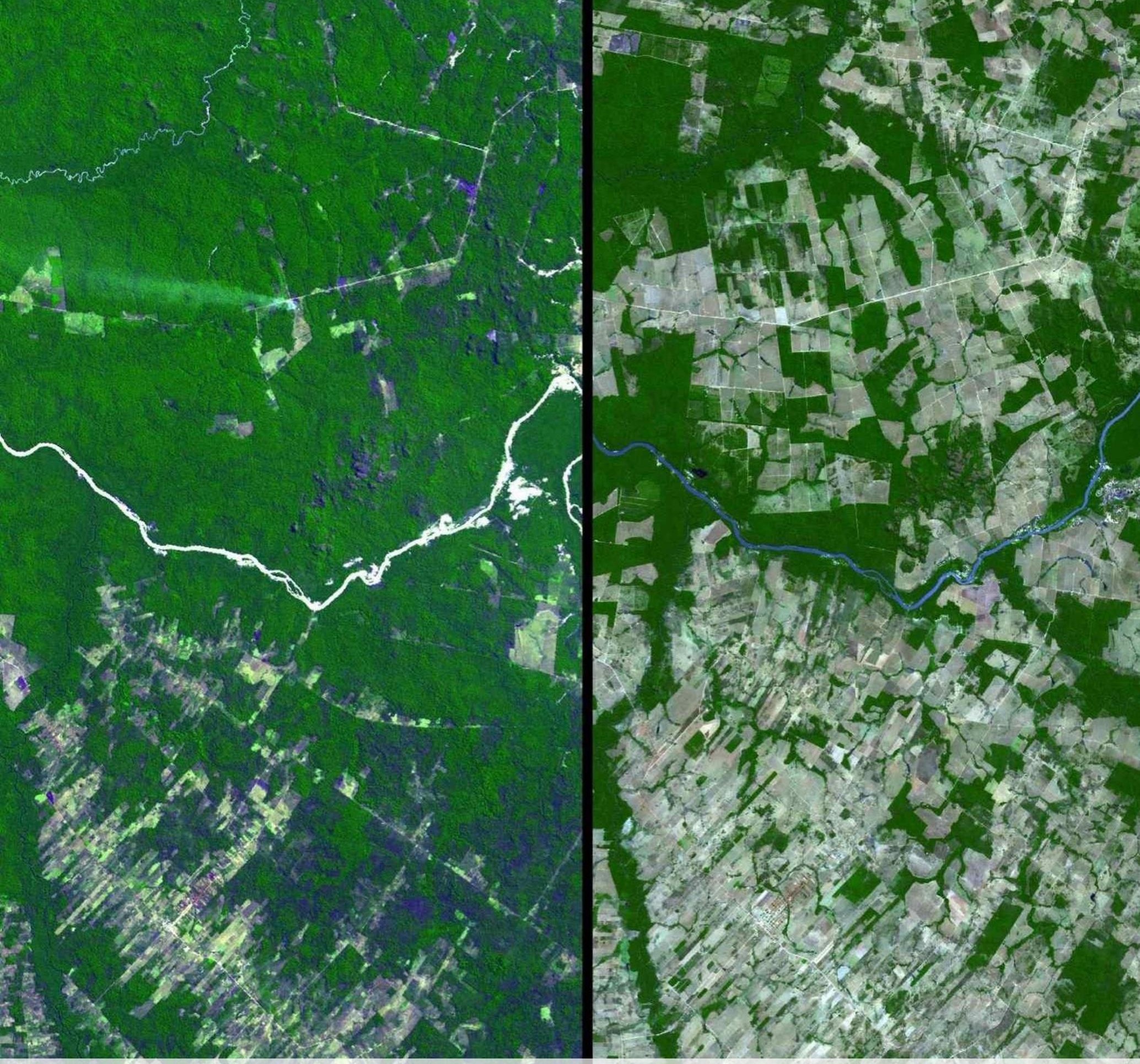

\section{Chapter 2. Investigating discharge and rainfall variability in an Amazonian watershed: Do any trends exist?}

Image source: https://www.jpl.nasa.gov/spaceimages/details.php?id=PIA11420

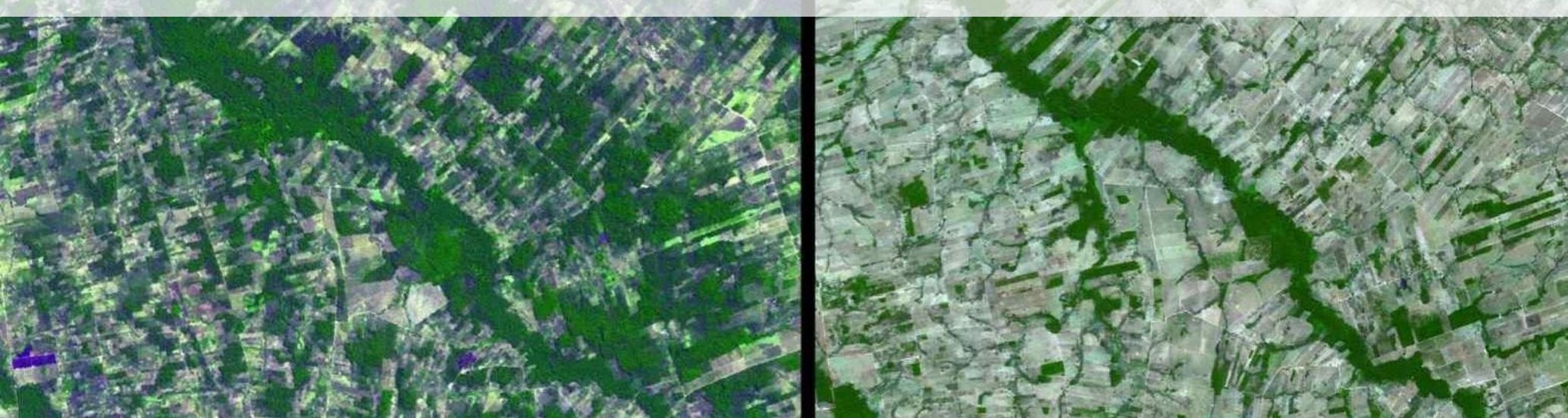




\title{
2. Investigating discharge and rainfall variability in an Amazonian watershed: Do any trends exist?
}

This manuscript is published as: Guzha, AC, Nóbrega, RLB, Santos, CAG, and Gerold, G. 2013. In: the Proceedings of H01 (IAHS Red Book, IAHS Publ. 359), IAHS-IAPSO-IASPEI Assembly, Gothenburg, Sweden.

\begin{abstract}
A trend analysis of stream discharge from the upper Mortes watershed, southern Amazon, was performed using discharge and rainfall data in order to investigate the temporal variability of stream discharge, and relate it to associated rainfall variability. Non-parametric tests were done on daily, seasonal and annual discharge data. Frequency analysis using wavelet transform was also done. Results indicate increasing trends in discharge. The wavelet analysis identified dry periods; i.e. 1967-1975, 1982-1986 and 1993, which were followed by wet periods. In some cases, discharge increases could not be satisfactorily correlated to the rainfall. Further interpretation of the data for possible causes of streamflow changes is needed and discussion of the implications of these results in the context of climate change, deforestation and water resource management.
\end{abstract}

Key words: trend analysis; streamflow; rainfall; Mann-Kendall test; wavelet transform.

\subsection{Introduction}

An important aspect of climate change and variability research is trend analysis of hydro-climatic variables using available records. Even though studies indicate that climate changes have a significant impact on streamflow and other hydrological processes (Milly et al., 2005), regional patterns of streamflow changes are complex and less certain. Streamflow responds to a number of factors which can be classified as climatic and non-climatic. Climate factors include temperature, precipitation, evaporation, wind speed and direction, cloud cover and a combination of these. Nonclimatic factors include catchment cover, vegetation, and man-made structures including diversion and detention structures such as dams. In the Amazon basin, conversion of forest to pasture is also known to influence watershed hydrological processes (Ziegler et al., 2004; Moraes et al., 2006; Zimmermann et al., 2006; Germer et al., 2009). While the influences of climatic changes and land- use variations on watershed hydrology cannot be investigated in isolation, understanding the influence of these watershed response drivers independently provides preliminary information. 
The debate on climate variability and climate change relies heavily on the detection of trends in records of hydroclimatic variables such as precipitation and streamflow. In many parts of the world, and in particular in the USA, Canada and Europe, numerous large-scale analyses of hydro-climatic trends have recently been conducted on precipitation and streamflow data at different time scales (e.g., Groisman et al., 2001; Zhang et al., 2001; Molnár and Ramírez, 2001; Burn \& Hag Elnur, 2002; Kahya and Kalayci, 2004; Birsan et al., 2005). However, such studies are limited in the South American continent (e.g., Rosenblüth et al., 1997).

Therefore, the main objective of this study was to identify trends in observed streamflow data and their occurrence in time in the Upper Rio Das Mortes watershed, and to analyse the linkages between any observed changes in streamflow and precipitation. As outlined by Jakeman and Hornberger (1993), it is important to determine: "what reliable information may reside in concurrent observed precipitationstreamflow measurements for assessing the dynamic characteristic of catchment response."

\subsection{Study Area Description}

The study was conducted in the upper Rio das Mortes watershed (Fig. 2.1) located in Mato Grosso State, Brazil. The watershed is located between $53^{\circ} 45^{\prime}$ and $55^{\circ} 30^{\prime} \mathrm{W}$, and $14^{\circ} 45^{\prime}$ and $16^{\circ} 00^{\prime} \mathrm{S}$, and covers an area of $17555 \mathrm{~km}^{2}$. The study area is in the western part of the Central Brazilian Plateau, where the basement of the South American platform is covered by Tertiary (Cachoeirinha formation) and Mesozoic (Bauru group) sedimentary rocks, which are mainly arenites and conglomerates. The main soil types in the watershed are red and yellow Latossolos (Brazilian classification system, EMBRAPA 1999).

The relief of this area is mostly flat to very gently undulating, and elevation varies from $336 \mathrm{~m}$ in the lowlands along the river network and the gallery forests to $908 \mathrm{~m}$ with slopes predominantly in the $1-5 \%$ range. The main soil types are the Latossolo Vermelho-Escuro and the Latossolo Vermelho-Amarelo Podsolico covering almost $70 \%$ of the watershed. The remaining natural vegetation, concentrated along the rivers, is dominated by the Cerrado and gallery forests. Land-use in this region is predominantly agricultural and it is one of the principal production areas of grain and 
cotton in Mato Grosso State with annual production of maize, cotton and soybeans. The Rio das Mortes River can be generally classified as a rain-fed river and is characterized by a pronounced seasonal flow regime showing year-to-year variability. Generally, high flows occur during the summer period (November to April) and low flows occur during winter (dry) season which, on average, spans from May to October. The daily flow ranges from 126 to $1615 \mathrm{~m}^{3} / \mathrm{s}$ with a long-term mean flow of $361 \mathrm{~m}^{3} / \mathrm{s}$.

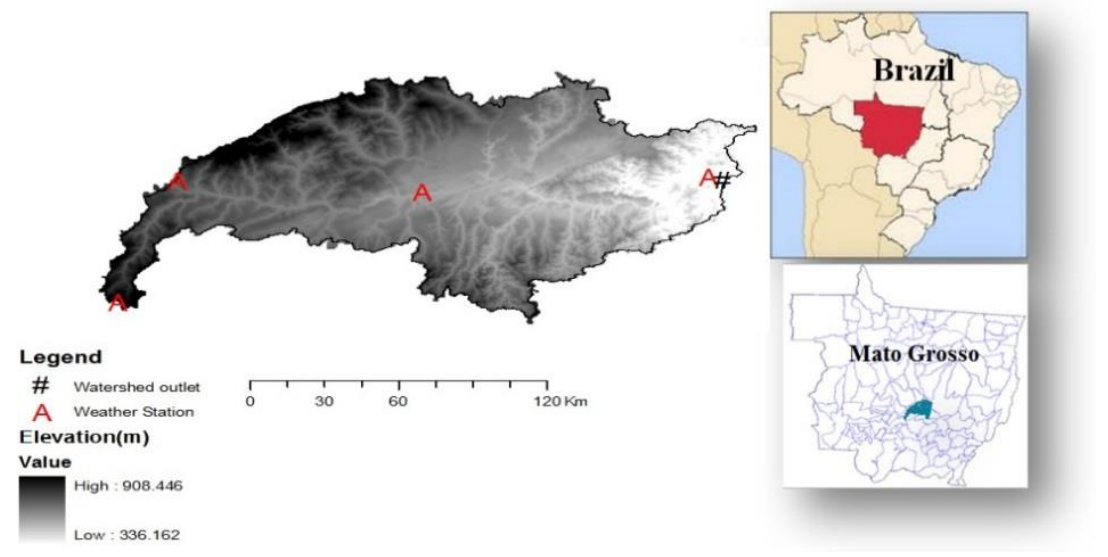

Figure 2.1 Upper Rio das Mortes watershed in central Mato Grosso State, Brazil.

The discharge gauge of Toriqueje (ANA 26050000) located at $15.31^{\circ} \mathrm{S} 53.08^{\circ} \mathrm{W}$ was selected because of the existence of a long time series (1967-2007) of daily discharge data. Discharge data were downloaded from http://www.ana.gov.br. Precipitation from four weather stations upstream of the gauging stating is spatially averaged to build the rainfall time series used in this study.

\subsection{Study methodology}

The methodology used in this study consisted of trend tests applied to 40 years' time series data of streamflow measured at the ANA gauging station (26050000) The magnitude of the trend slope was also determined for each time series. Trend analysis of hydrometric data is most commonly performed using the Mann-Kendall nonparametric tests. The main reason for using non-parametric statistical tests is that compared to parametric statistical tests, the non-parametric tests are thought to be more suitable for non-normally distributed data and censored data, which are frequently encountered in hydro-meteorological time series (Ehsanzadeh et al., 2010). This method was adopted in this study. To avoid serial auto-correlation complications, Kendall's test was applied on annual basis. The calculated Mann-Kendall trend 
statistic determines the statistical significance of a trend in a data set. Decadal flow duration curves were also generated. Low-flow magnitude and frequency are used often by water-supply planners and reservoir managers to manage water availability for supply. In this study, we estimated the 7-day low flows and the Mann-Kendall test was also applied to test for any significant trends in the 7-day low flow time series. The 7-day low flow in any year is determined by calculating the average flow over seven consecutive days for every seven-consecutive-day period in the year and choosing the lowest. The trend was considered to be significant if the probability value ( $p$-value) was less than or equal to 0.05 . This value represents a 95-percent confidence level.

Precipitation data from four stations located within the study watershed were analysed in this study.

\subsection{Results and discussion}

\subsubsection{Annual rainfall and streamflow}

The Mann-Kendall trend test applied to annual rainfall showed no statistically significant upward or downward trend in the watershed (Fig. 2.2a). To investigate if the trends in annual streamflow were related to climatic factors, mean annual stream flows for the period 1967-2007 were analysed using the same method and the results are shown in Fig. 2.2b and 2.2c. Monthly streamflow data revealed important trends in the natural hydrological regime of the watershed. A statistically significant upward trend was detected in the watershed at the 0.01 and 0.05 levels of significance for annual streamflow (Fig. 2.2b). A similar trend was also observed for the 7-day low flows (Fig. 2.2c). The Sen's slopes of the trends in streamflow are also presented and confirm these findings.

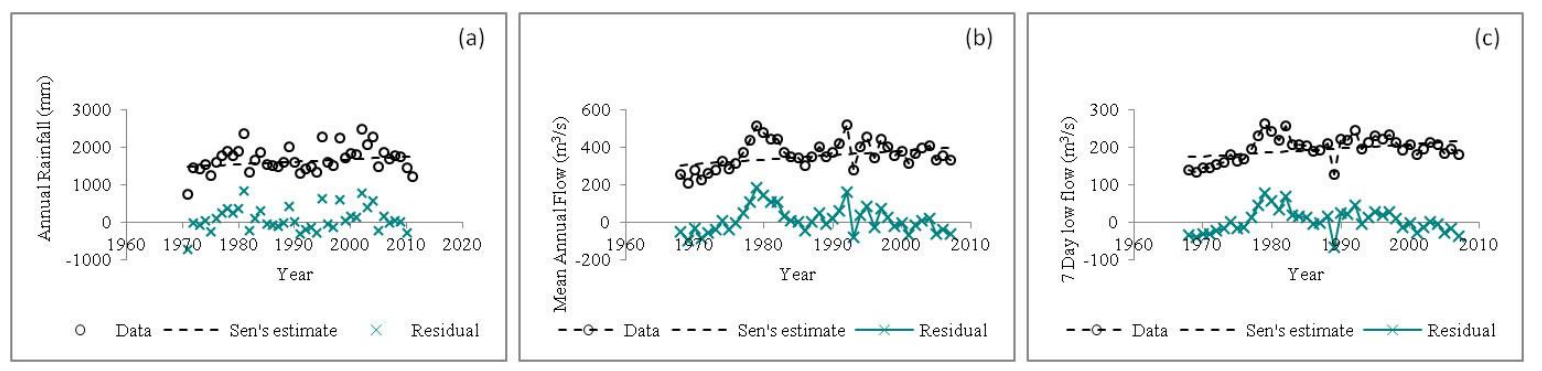

Figure 2.2 Mann-Kendall test on (a) annual rainfall in the study watershed, (b) the mean annual streamflows, and (c) 7-day low flows recorded at ANA 26050000 gauging station. 


\subsubsection{Decadal flow duration curves}

The decadal flow duration curves (Fig. 2.3) show a marked increasing shift in discharge after the 1968-1977 decade. As there is no marked increase in annual precipitation during this period, these results show that streamflow trends are influenced more by other forces. Low $\left(Q_{75-100}\right)$, median $\left(Q_{45-55}\right)$ and high $\left(Q_{0-10}\right)$ flows derived from the decadal flow duration curves are shown in Table 2.1. The decadal values flow values also show significant changes in streamflow after 1968-1977.

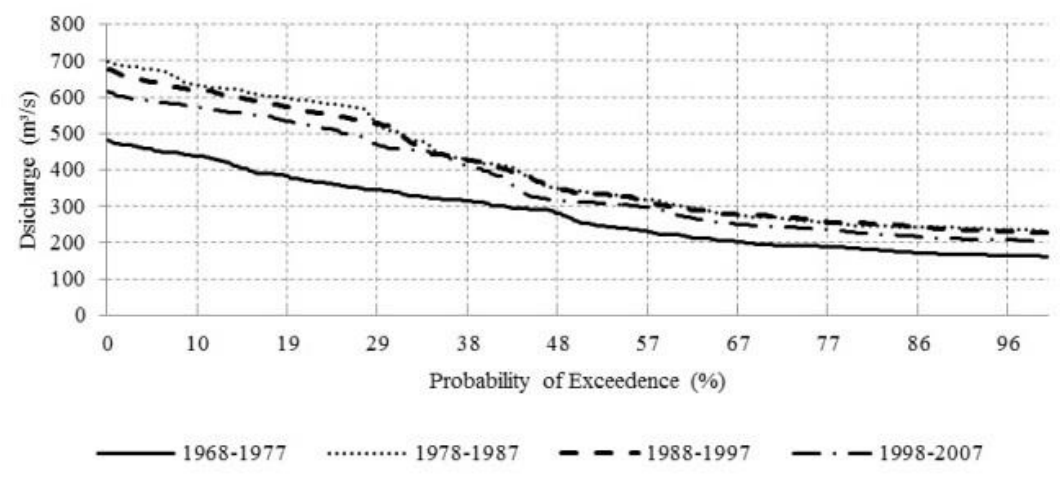

Figure 2.3 Decadal flow duration curves for stream flow measured at the ANA station 26050000 for the period 1968-2007.

Precipitation variability could be the main driver of changes in the hydrological response in a watershed and could mask other changes in the nature of rainfall-runoff response (Rodriguez et al., 2010). However, from this study, increasing discharge changes are not matched by increases in precipitation, over the four decades. There is no evidence of any increasing trend in precipitation. This suggests that other factors are more important in this watershed in controlling streamflow trends. Land-use change from forest to agriculture and pasture, is generally considered a leading cause for changes in watershed hydrological responses, through changes in runoff generation mechanisms.

Table 2.1 Decadal low, medium and high stream flows derived from flow duration curves.

\begin{tabular}{ccccc}
\hline & $1968-1977$ & $1978-1987$ & $1988-1997$ & $1998-2007$ \\
\hline High flow $\left(Q_{0-10}\right)$ & 418 & 630 & 607 & 560 \\
Median flow $\left(Q_{45-55}\right)$ & 264 & 344 & 344 & 313 \\
Low flow $\left(Q_{75-100}\right)$ & 173 & 243 & 242 & 217 \\
\hline
\end{tabular}

\subsubsection{Wavelet analysis}

Wavelet analysis maintains time and frequency localization in a signal analysis by 
decomposing or transforming a one-dimensional time series into a diffuse twodimensional time-frequency image simultaneously. Then it is possible to get information on both the amplitude of any "periodic" signals within the series, and how this amplitude varies with time. This information was not readily available in the raw signal (Fig. 4(a)). Thus, Fig. 4(b) is the diffuse two-dimensional simultaneously timefrequency image called the wavelet power spectrum.

Wavelet power spectrum: Figure 4(a) shows the raw data of the daily streamflow at Araguaia gauge. Figure 4(b) shows the power (absolute value squared) of the wavelet transform for those raw data, using the Morlet mother wavelet because it gives more accurate frequency information. Figure 4(b) shows the actual oscillation of the individual wavelet rather than just its magnitude. Observing it, the concentration of power can be easily identified in the frequency or time domain, i.e. an annual frequency along the entire time series (1967-2007), but with high concentration starting in 1972, which is highlighted by the thick contours. The variance of power in the 256-512-day band (also confirmed by Fig. 4(c)) also shows the dry and wet years; i.e. when the power decreases substantially in this band, it means a dry year and when the power is maximum means a wet year, as discussed by Santos et al. $(2001,2003)$ and Santos and Ideião (2006). The area below the well-defined line is called the influence cone, where zero padding was performed. Thus, this area must be avoided; e.g. there is a power concentration until 1990 at the 4096-8192-day band (a hydrological event occurring each 15 years), but this must be influenced by the zero padding.

Global wavelet power spectrum: The global wavelet spectra provide an unbiased and consistent estimation of the true power spectrum of the time series. The dashed line is the $5 \%$ significance level for the global wavelet spectrum, using a red-noise background spectrum. Trends of the time series are confirmed by an integration of the power over time spectrum, assuming red-noise, represented by the dashed lines (Fig. 4(c)). Many geophysical time series can be modelled as either white-noise or rednoise. As explained by Torrence and Compo (1998), a simple model for red-noise is the univariate lag-1 autoregressive process. The lag-1 $\left(\alpha_{1}\right)$ is the correlation between the time series and itself, but shifted (or lagged) by one time unit. In this present case, this would be a shift of one day. The lag-1 measures the persistence of an anomaly 
from one day to the next. When the lag- 1 is greater than 0.4 , it is recommended to compute the true lag- $1 \alpha$ as $\alpha=\left(\alpha_{1}+\alpha 2^{1 / 2}\right) / 2$, in which $\alpha_{2}$ is the autocorrelation lag-2, which is the same as lag-1 but lagged by two days instead of one day. When $\alpha_{1}$ is less than 0.4 , it is recommended to model the series as white-noise ( $\alpha=0)$. The null hypothesis is defined for the wavelet power spectrum as assuming that the time series has a mean power spectrum, and then it can be assumed to be a true feature with a certain percent confidence. For definitions, "significant at the $5 \%$ level" is equivalent to the "95\% confidence level," and implies a test against a certain background level, while the "95\% confidence interval" refers to the range of confidence about a given value (Torrence and Compo 1998).
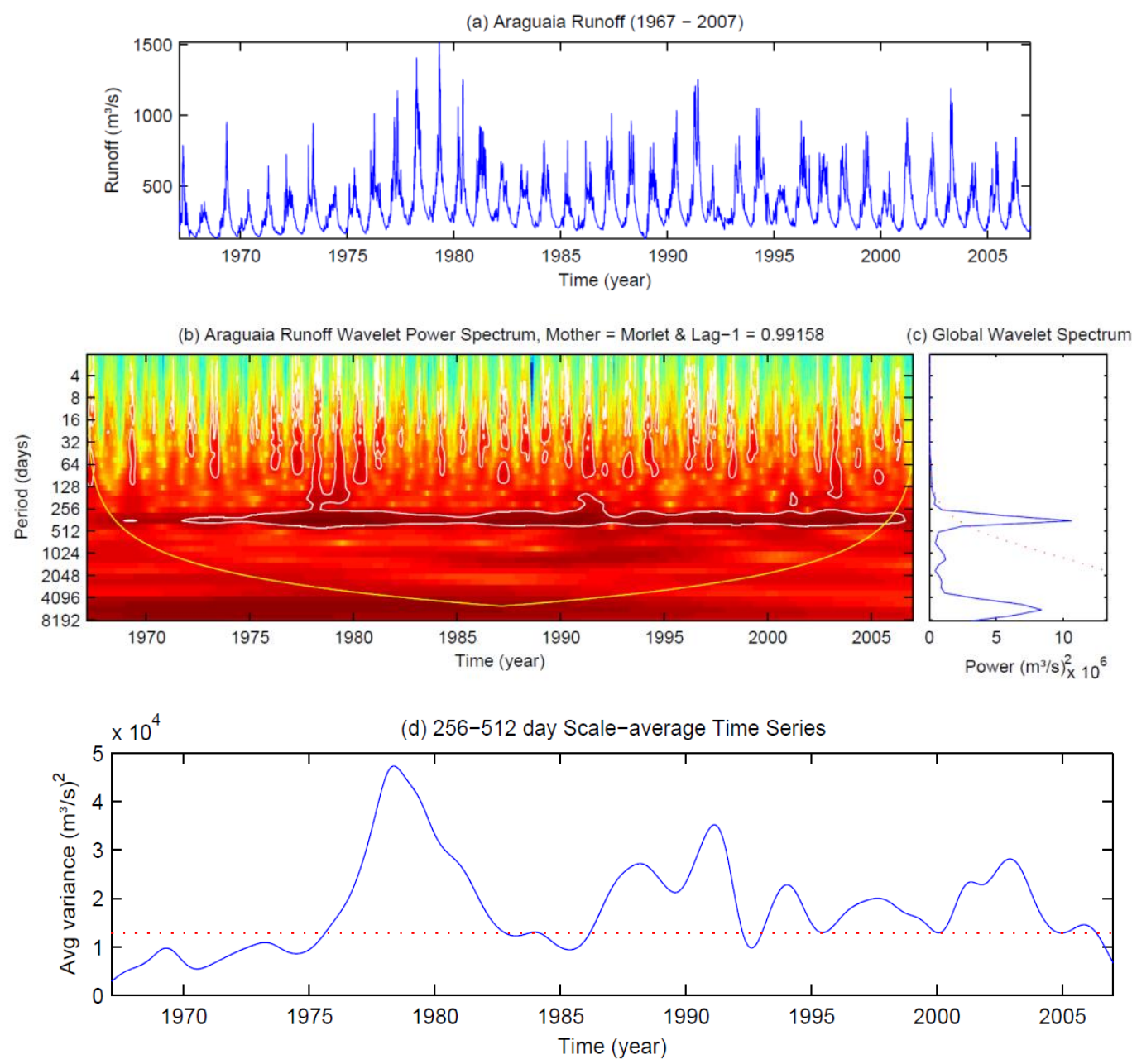

Figure 2.4 (a) Daily streamflow at Araguaia gauge for the 1967-2007 period. (b) The wavelet power spectrum using Morlet mother wavelet. The thick contour encloses regions of greater than $95 \%$ confidence for a red-noise process with a $\square$ coefficient of 0.99158 . (c) The global wavelet power spectrum. The dashed line is the $5 \%$ significance level for the global wavelet spectrum, using a red-noise background spectrum. (d) Scale-average wavelet power over the 256-512-day band. The dashed line is also the $95 \%$ confidence level assuming red-noise. 
Scale-average time series: The scale-average wavelet power is a time series of the average variance in a certain band. On the case of Fig. 4(d), it is the 256-512-day band. It can be used to examine modulation of one frequency by another within the same time series. Figure 4(d) is generated as the average of Fig. 4(b) over all scales between 256 and 512 days. A dry period can be identified between 1967 and 1975, followed by a wet period until the beginning of 1982 . Other reductions in power can be also found between the years 1982-1986 and in 1993, which correspond to dry years followed by wet periods.

\subsection{Conclusions}

Analyses of historical records of annual precipitation and discharge could have potential applications to help water managers and decision makers make informed decisions regarding water resources management and economic development planning, especially considering predicted future climatic change scenarios. From this study, the following conclusions can be made: (a) Stream discharge in the study watershed has increased over the past four decades. Similar trends were observed for high, medium and low flows estimated using flow duration curves. However, the nature of the observed change is not completely known. This can vary from simple upward trends that are monotonic to increasing shifts in the average values, or may be a combination of both. Further investigation of this trend and an extension to other watersheds within the basin is required. (b) Mean annual precipitation during this same period under consideration (1967-2007) indicate no statistically significant evidence of an increasing or decreasing trend. Results from this study indicate that the observed increasing trend in streamflow is most likely influenced by other factors in the watershed besides the precipitation pattern. Land-use change patterns that have occurred in the study area in the last few decades are likely to play a significant role in the observed streamflow trends. (c) Although the study is limited and cannot be used in isolation to determine watershed changes in low-flow conditions, the study provides an important pattern where streamflow increase is not matched by increases in annual rainfall amounts. Prediction in ungauged watersheds and basins is an important topic in hydrological studies. The low-flow determinations in this study and trend analysis could be used in conjunction with basin characteristics to develop 
regional equations for estimating low flows at ungauged streams. Finally, (d) This study represents an initial step towards a quantitative understanding of historical changes in precipitation and streamflow in the Upper Das Mortes watershed. Literature suggests a variety of anthropogenic factors influencing the watershed hydrology climate of southern Amazonia watersheds which may overshadow any climatic change signals. Ongoing studies include quantifying spatial and temporal land use/land cover dynamics and investigating how these observed changes influence streamflow trends, establishing trends in parameters controlling overall watershed water balance and seasonal trends and use hydrologic models to predict the influence of likely future land use land cover scenarios and climate on watershed hydrology.

Acknowledgements: This work is part of the CARbon sequestration, BIOdiversity and soCIAL structures project (CARBIOCIAL) in Southern Amazonia with funding provided by the Germany Bundesministeriums für Bildung und Forschung (BMBF). We also thank the support and collaboration from DAAD and our research partners in Brazil. 


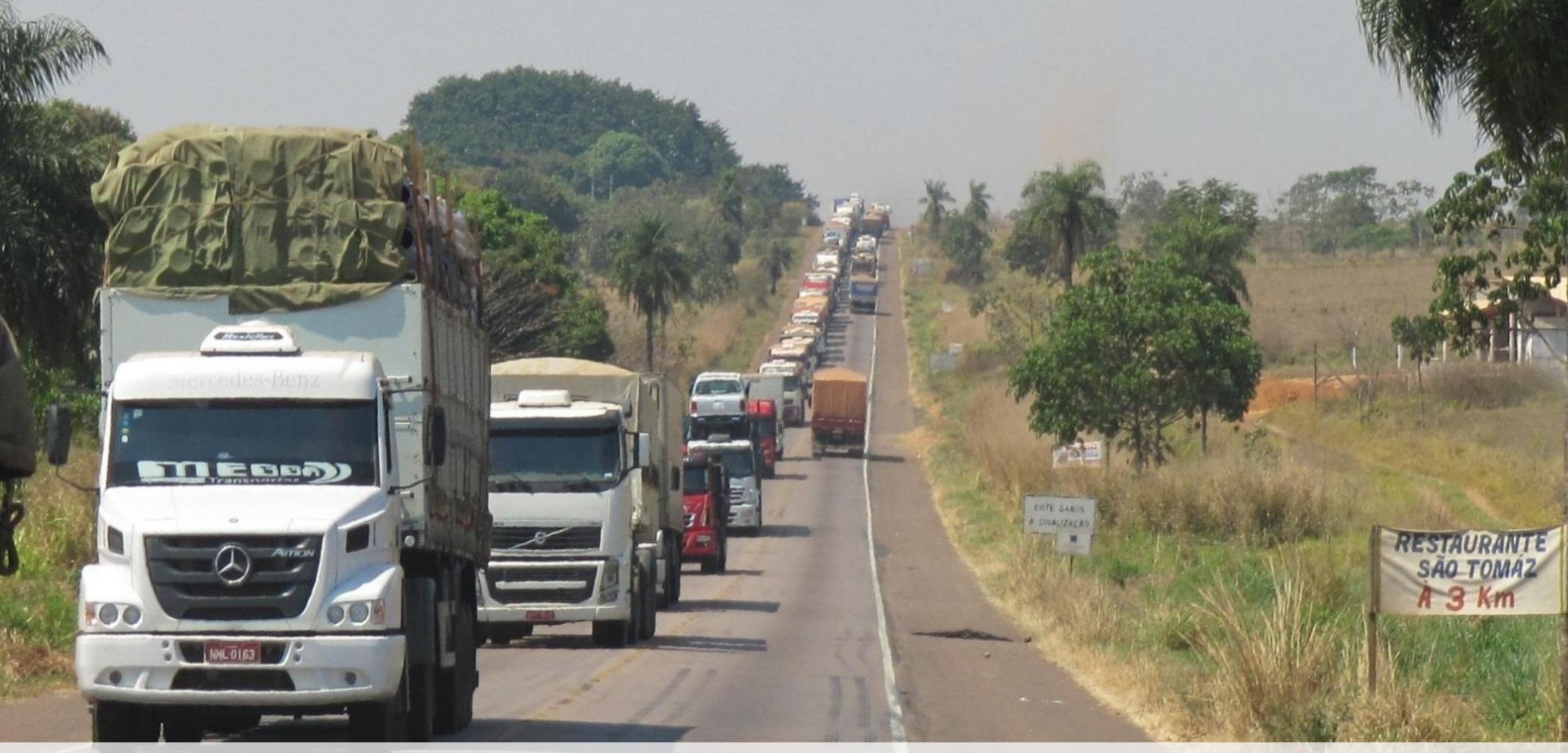

Chapter 3. A multi-approach and multi-scale study on water quantity and quality changes in the Tapajós River basin, Amazon 


\section{A multi-approach and multi-scale study on water quantity and quality changes in the Tapajós River basin, Amazon}

This manuscript is published as: Nóbrega, RLB, Lamparter, G, Hughes, H, Guzha, AC, Amorim, RSS, Gerold, G. 2018. A multi-approach and multi-scale study on water quantity and quality changes in the Tapajós River basin, Amazon. Proc. Int. Assoc. Hydrol. Sci. 377, 3-7. DOI:10.5194/piahs-377-3-2018.

\section{Abstract}

We analyzed changes in water quantity and quality at different spatial scales within the Tapajós River basin (Amazon) based on experimental fieldwork, hydrological modelling, and statistical time-trend analysis. At a small scale, we compared the river discharge (Q) and suspended-sediment concentrations (SSC) of two adjacent microcatchments $\left(<1 \mathrm{~km}^{2}\right)$ with similar characteristics but contrasting land uses (forest vs. pasture) using empirical data from field measurements. At an intermediary scale, we simulated the hydrological responses of a sub-basin of the Tapajós (Jamanxim River basin, 37,400 km²), using a hydrological model (SWAT) and land-use change scenario in order to quantify the changes in the water balance components due to deforestation. At the Tapajós' River basin scale, we investigated trends in $Q$, sediments, hydrochemistry, and geochemistry in the river using available data from the HYBAM Observation Service. The results in the micro-catchments showed a higher runoff coefficient in the pasture (0.67) than in the forest catchment (0.28). At this scale, the SSC were also significantly greater during stormflows in the pasture than in the forest catchment. At the Jamanxim watershed scale, the hydrological modelling results showed a $2 \%$ increase in $Q$ and a $5 \%$ reduction of baseflow contribution to total $Q$ after a conversion of $22 \%$ of forest to pasture. In the Tapajós River, however, trend analysis did not show any significant trend in discharge and sediment concentration. However, we found upward trends in dissolved organic carbon and $\mathrm{NO}_{3}$ over the last 20 years. Although the magnitude of anthropogenic impact has shown be scaledependent, we were able to find changes in the Tapajós River basin in streamflow, sediment concentration, and water quality across all studied scales.

\subsection{Introduction}

Southern Amazonia was the first region of Brazil's Amazon area to be exposed to intensive conversion to agricultural lands (Fearnside, 2016). The Tapajós River, an important tributary of the Amazon River, lost in this basin ca. 30\% of forest cover (ca. $500,000 \mathrm{~km}^{2}$ ) by 2016 , mainly due to the establishment of agro-industrial farms. The forest loss in this River basin is projected to reach approximately $65 \%$ by 2050 (Soares-Filho et al., 2006). 
The understanding of small areas is essential to propose solutions to maintain tropical forest services, such as water and nutrient cycling, in the Amazon (Vedovato et al., 2016). These areas can be well assessed by experimental catchment studies. For example, Bleich et al. (2016) studied 10 small pristine streams in the Tapajós River basin and argue that in case measures of conservation of small catchments are not taken, environmental impacts on regional streams in South Amazonia are expected to increase. Impacts at regional scales have been the concern of the scientific community with regards to the role of tropical forests in the global climate systems, especially the effects of the Amazon deforestation in large scales (Ometto et al., 2011). Lima et al. (2014) argue that large-scale deforestation triggers complex non-linear interactions between the atmosphere and biosphere, which may impair important ecosystem services such as water for agriculture and hydroelectric power generation.

Although it has been reported that deforestation leads to changes in the water cycle in this region (Davidson et al., 2012), the effects of forest clearing on the concentrations of suspended and dissolved materials that are usually seen in small streams are difficult to be detected in larger streams and rivers (Thomas et al., 2004). However, the chemistry of the large rivers in the Amazon that remained relatively unaltered until 2000 was compromised because of the upcoming growing of area occupied by pastures (Neill et al., 2001). Additionally, analyses of land-use change impacts that were usually limited to small plots or experimental catchments are now possible to be applied to larger scales, such as river basins, due to recent improvements in data collection, archiving and distribution (Eshleman, 2004). New evidence shows that the conversion of forest to pasture is manifested in systematic changes in the hydro-climatology cycle with increase in river discharge in large catchments in the Amazon (Souza-Filho et al., 2016).

In this study, we examined the impact of the land-use change on the streamflow and water quality of the Tapajós River basin using different spatial scales and approaches. We seek to understand what signatures from the land-use change are possible to observe within and across these scales. 


\subsection{Area of study}

Our study focus on the Tapajós River basin (ca. 500,000 km²), which is the fifth largest sub-basin of the Amazon River and covers 7\% of the total Amazon basin (Pavanato et al., 2016). This basin includes 7 of the 41 municipalities where Brazilian Environmental authorities concentrate anti-deforestation efforts due to their high incidence of forest clearing (Bragança, 2015). In order to estimate the impacts of scale, we integrated to our study a sub-basin of the Tapajós, the Jamanxim River basin $\left(37,400 \mathrm{~km}^{2}\right)$, and a pair of micro-catchments $\left(<1 \mathrm{~km}^{2}\right)$ with contrasting land uses (forest vs. pasture) located in the municipality of Novo Progresso, in the Brazilian state of Pará (Fig. 3.1). The climate in this area is humid tropical with a rainy season from November to May and a dry season that extends from June to October. Mean annual precipitation averages $1,900 \mathrm{~mm}$.

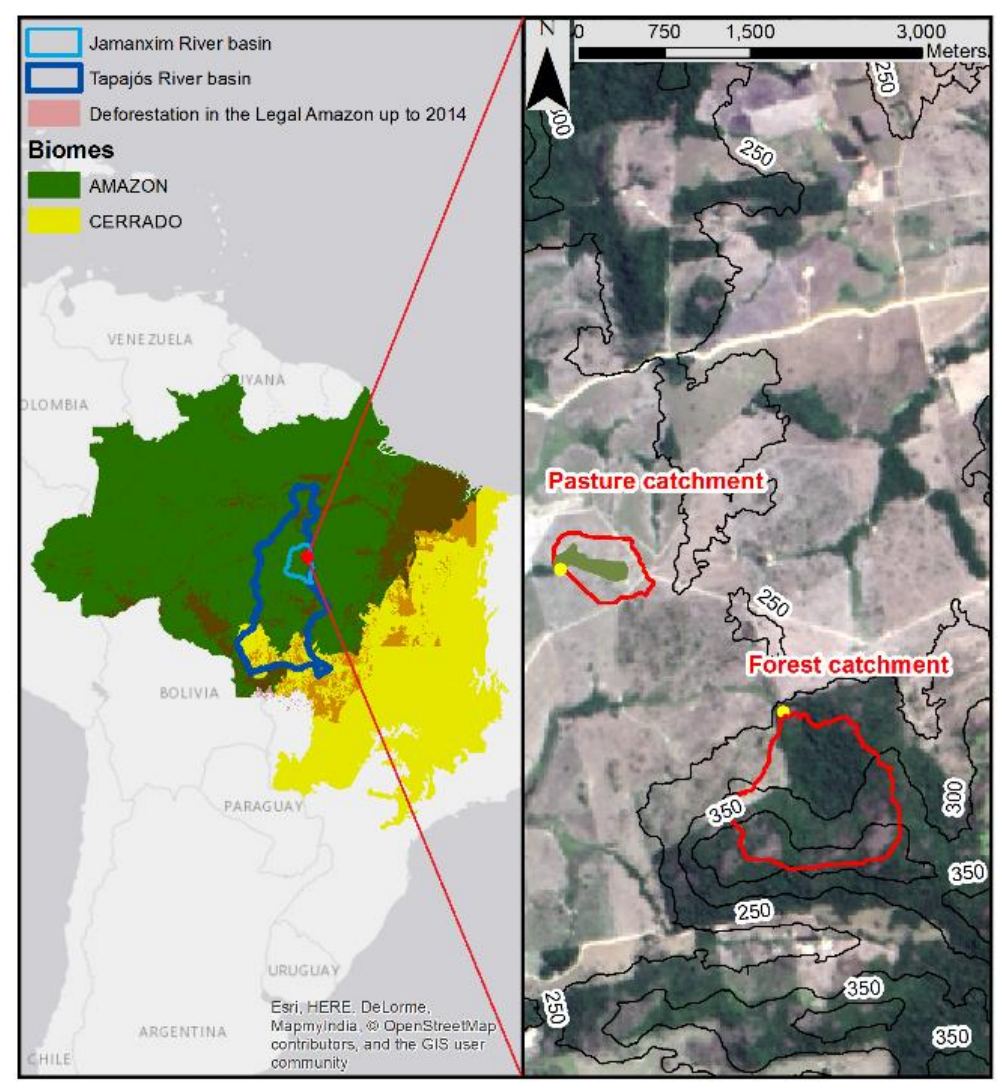

Figure 3.1 Area of study. 


\subsection{Methods}

\subsubsection{Experimental micro-catchment study}

We compared the streamflow of the micro-catchments by using empirical data from field measurements from 2013 to 2014. At the catchment outlets, we installed rectangular weirs and a DS 5X multiparameter sonde (OTT, USA) to measure water level and to quantify streamflow. In these catchments, we also collected 1-L water samples during stormflow events for suspended sediment concentration (SSC) analysis following the method of ASTM (2000). More details on the catchments' characteristics and instrumentation setup can be found in Guzha et al. (2015).

\subsubsection{Jamanxim River basin modelling}

We simulated the hydrological behavior of the Jamanxin River basin using the SWAT eco-hydrological model (Arnold et al., 2012). For the setup, calibration and validation of SWAT, we used a gradual land-use change parameterization, field assessments, and available regional data, and then simulated a land-use change scenario in order to quantify the changes in the water balance components due to deforestation. The model parameterization, calibration and validation details can be found in Lamparter et al. (2016). The land-use change scenario used in this study (Fig. 3.2) suggests a rapid pasture expansion according the study of Gollnow et al. (2017).

\subsubsection{Tapajós River basin analysis}

We investigated trends in $Q$, sediments, hydrochemistry, and geochemistry in the river using available data from the HYBAM Observation Service (www.ore-hybam.org). We used Mann-Kendall test for detecting either an upward or downward trend in the data series with a significance threshold set at .05 . The data were also used to quantify fluxes of nitrate and total dissolved carbon (DOC) in 5-year periods from 1996 to 2015.

\subsection{Results and Discussion}

Figure 3.3 shows the streamflow comparison between the two micro-catchments. The pasture catchment has a higher runoff coefficient $(0.67)$ than the forest catchment (0.28). Baseflow indices were 0.76 and 0.88 for the pasture and forest catchments, respectively, showing a higher baseflow contribution in the forest catchment. At this 
scale, the SSC were also significantly higher during stormflows in the pasture (579.7 $\left.\pm 985.3 \mathrm{mg} \mathrm{L}^{-1}\right)$ than in the forest catchment $\left(81.8 \pm 148.6 \mathrm{mg} \mathrm{L}^{-1}\right)$.

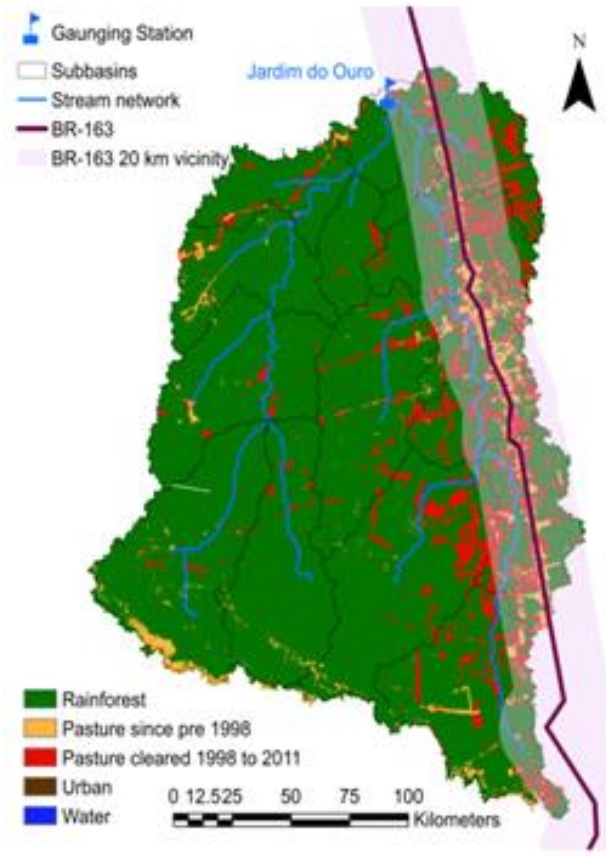

(a)

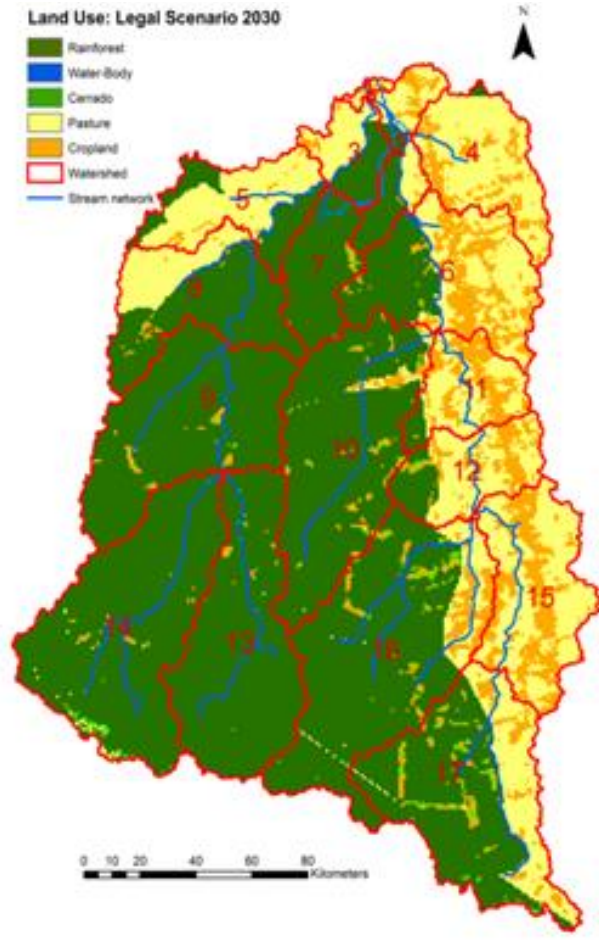

(b)

Figure 3.2 (a) Land-use distribution in 2011, and (b) Land-use scenario (22\% of deforestation) for the year 2030 following a business as usual approach (Göpel \& Schaldach, 2016).

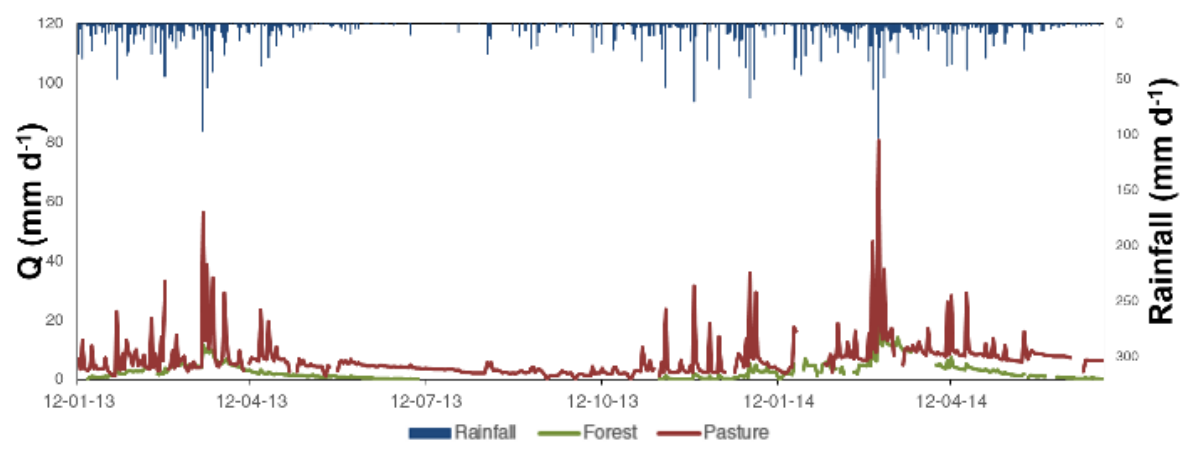

Figure 3.3 Streamflow and rainfall in the forest and pasture micro-catchments.

For the Jamanxim River basin, simulation results show a 2\% increase in discharge $(Q)$ and a $5 \%$ reduction of baseflow contribution to total $Q$ after a $22 \%$ conversion of forest to pasture (Fig. 3.4 and Table 3.1). Our results are in accordance to Davidson et al. (2012); they state that even though basin-scale impacts of land use may not yet surpass the magnitude of natural hydrological variability and biogeochemical cycles, 
there are some signs of a transition to a disturbance-dominated regime, which include changes in the water cycle in the Southern and Eastern regions of the Amazon basin.

Table 3.1 $Q$ results with SWAT for the land-use distribution and scenario.

\begin{tabular}{ccccc}
\hline $\begin{array}{c}\mathbf{P} \\
(\mathbf{m m})\end{array}$ & $\begin{array}{c}\mathbf{Q} \\
(\mathbf{m m})\end{array}$ & $\begin{array}{c}\mathbf{Q} \\
\text { Scenario } \\
(\mathbf{m m})\end{array}$ & $\begin{array}{c}\text { Qbase } \\
(\mathbf{m m})\end{array}$ & $\begin{array}{c}\text { Qbase } \\
\text { Scenario } \\
(\mathbf{m m})\end{array}$ \\
\hline $\mathbf{1 , 6 3 9}$ & 637 & 685 & 396 & 405 \\
\hline
\end{tabular}

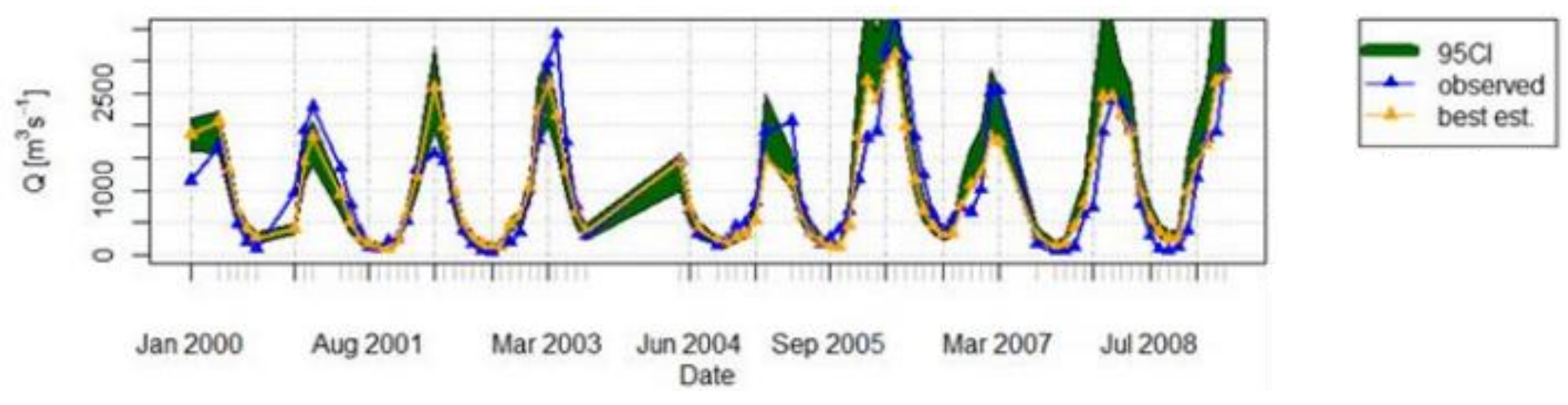

Figure 3.4 Calibration and validation with land-use update for the Jamanxim catchment.

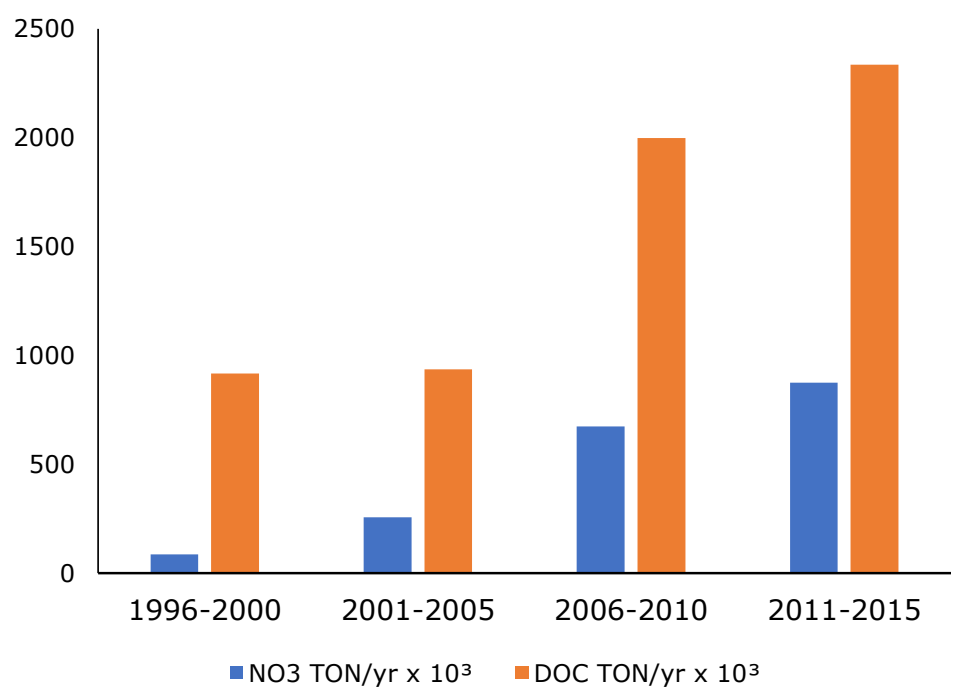

Figure 3.5 Nitrate and total dissolved carbon fluxes.

At the scale of the Tapajós River basin, however, trend analysis did not show any significant trend in discharge and sediment concentration. Hydrological changes due to land-use change are known to be primarily manifested at smaller scales. Therefore, we ascribe the absence of visible trend at a large scale to the fact that most of the 
deforestation in the Tapajós River basin has occurred in its upper portion, which produces hydrological signatures that may be buffered along the river until its outlet. The analyses of the outflow fluxes over the last 20 years in the Tapajós River revealed upward trends in dissolved organic carbon and $\mathrm{NO}_{3}$, which have reached an up to 10fold increase (Fig. 3.5).

\subsection{Conclusions}

Effects of deforestation on large rivers of the Amazon basin were relatively unknown due to the low degree of connection between large rivers and land uses in these basins (Neill et al., 2001). We were able to find changes in the Tapajós River basin in river discharge, sediment concentration, and water quality across all studied scales. In this context, our study adds to an increasing body of literature showing that although the magnitude of anthropogenic impact has shown to be scale-dependent, some changes are detectable in both small and large rivers in the Amazon.

Competing interests. The authors declare that they have no conflict of interest.

Acknowledgments. This research was feasible thanks to the support of the Bundesministerin für Bildung und Forschung (BMBF) through the grant to the CarBioCial project (grant number: 01LL0902A). The authors also acknowledge the data availability of HYBAM Observation Service and the National Water Agency of Brazil (ANA). 


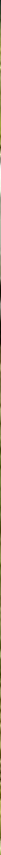

\section{Chapter 4. Characterizing rainfall runoff signatures from micro- catchments with contrasting land cover characteristics in southern Amazonia}




\title{
4. Characterizing rainfall runoff signatures from micro catchments with contrasting land cover characteristics in southern Amazonia
}

This manuscript is published as: Guzha, AC, Nóbrega, RLB, Kovacs, K, Rebola-Lichtenberg, J, Amorim, RSS, Gerold, G. 2015. Characterizing rainfall-runoff signatures from micro-catchments with contrasting land cover characteristics in southern Amazonia. Hydrol. Process. 29, 508-521. DOI:10.1002/hyp.10161.

\begin{abstract}
Based on interactions between landscape characteristics and precipitation inputs, watersheds respond differently to different climatic inputs. The objective of this study was to quantitatively characterize controls on runoff generation from two first order micro-catchments in the Amazonia region. The study investigated the variation of hydrological signatures at micro-catchment scale, and relates these to landscape and land cover differences and weather descriptors that control the observed responses. One catchment is a pasture cleared of all natural vegetation in the early 1980's and the second catchment is a primary tropical forest with minor signs of disturbance. Water levels and meteorological variables were continuously monitored during the study period (December 2012-May 2013). Water level measurements were converted to discharge, evapotranspiration was quantified using Penman-Monteith equation and catchment pedohydrological properties were also determined. During the study period, mean total rainfall was $1200 \mathrm{~mm}$ and runoff ratios were 0.79 and 0.47 for the pasture and forest catchments, respectively. Base flow index was relatively higher in the forest catchment (0.76) compared to pasture catchment (0.63). Results from this study showed that the pasture catchment had a $35 \%$ higher mean stream flow. Analysis of selected individual rainstorm events also showed peak discharges were attained much faster in the pasture catchment compared to the forest catchment. At both sites, rainfall-runoff responses were highly dependent on surface and subsurface flow generation. Overland flow was observed in the pasture site during intense rainfall events. The pasture catchment exhibited higher event water contribution than the forest catchment. Findings from this research suggest that shallow lateral pathways play a significant role in controlling runoff generation processes in the forest catchment, while infiltration excess runoff generation processes dominate in the pasture catchment. Results from this study suggest that the conversion of forest to pasture may lead to important changes in runoff generation processes and water storage in these head water catchments.
\end{abstract}

Key Words: hydrological processes, spatial and temporal variations, water balance, land cover, Amazonia. 


\subsection{Introduction and objectives}

Even though there is a general agreement on the importance of the Amazonia forest to world's climate, rainfall patterns and water resources, there is relatively limited research on examining the influences of land use changes on catchment hydrology in the humid tropics (Roa-Garcia and Weiler, 2010; Roa-Garcia et al., 2011). Tropical forest watersheds are valuable terrestrial ecosystems for biodiversity and provision of water related ecosystem services (Hamilton et al., 1995; Tognetti et al., 2010; Zadroga, 1981). However, dramatic degradation in these ecosystems have occurred in the last few decades (Scatena et al., 2010). While there is substantial evidence that the conversion of forest to pasture or crops in the tropics is associated with an increase in annual stream flow totals because of the lower evapotranspiration of the replacement vegetation, there are reports of diminished stream flows during the dry season, and in this respect, the effects of tropical forest conversion on catchment hydrology are even less understood (Bruijnzeel et al., 2011). Scientific conclusions and inferences generated from modeling efforts have often been tampered with limited field data and based on model parameter calibration and thus increased uncertainty in the model predictions. As stated by Blume et al. (2007), basin inter-comparison and maximization of the scientific value of available data sets, and field campaigns are important in order to generate data sets for catchments and watersheds in various study regions.

Headwater catchments can play a significant role in understanding the influence of anthropogenic and climate changes on stream flow dynamics because of their relatively small contributing areas which make them highly responsive to changes in energy, water, and chemical inputs (Roa-García et al., 2011). The low-order streams in these catchments are the sources or origins for larger rivers and therefore hydrological signatures from these may serve as useful indicators of different catchment stresses.

Classical and recent studies show that hydrologic properties of catchments, including infiltration and hydraulic conductivity are strongly affected by various stresses (Alegre and Cassel, 1996; Schoenholtz et al., 2000) and these properties play a key role in surface and sub-surface flow paths, and runoff generation (Elsenbeer, 2001; 
Elsenbeer and Lack, 1996) and subsequently hydrochemical dynamics. While the intensity and amount of rainfall are key factors, recent studies give rise to the assumption that besides the amount of precipitation, other factors play important roles in controlling seasonal patterns of catchment hydrochemical signatures (Breitenbach et al., 2010; Feng et al., 2009; Kebede and Travi, 2011; Lee et al., 2009).

Schnorbus and Alila (2013) observed that land use change did not have a statistically significant $(\alpha=0.05)$ impact on the peak flow distribution until a threshold level (20$30 \%$ ) in spatial extent of the land use change (forest harvesting in their case). They also noted that the magnitude of peak flow change is a function of changes in input fluxes (rainfall minus evapotranspiration) and changes in runoff synchronization, which directly affect peak discharge magnitude and timing. Thus understanding catchment characteristics is an important prerequisite for evaluating the effects of various anthropogenic and climatic drivers in catchment hydrological responses, and subsequent hydrochemical dynamics.

As outlined by Pfeffer et al. (2013), existing data and knowledge points out the central role of land use and confirm that land cover changes have a greater impact on runoff production than the rainfall amounts (Séguis et al., 2004; Boulain et al.,2009; Massuel et al., 2011). De Moraes et al. (2006), asserts that the removal of forest decreases interception and evapotranspiration (Wright et al., 1996), increases soil moisture levels (Hodnett et al., 1995) and groundwater recharge (Jipp et al., 1998), decreases infiltration capacity and soil water storage capacity of the upper root zone, and increases both quick flow and delayed flow to various degrees that depend on the land-cover history. While the runoff responses of catchments are mainly influenced by rainfall regime, topography, vegetation, and soil hydraulic properties (Dunne, 1978), Bonell and Balek (1993) observed the differences in these driving variables between temperate landscapes and the humid tropics. In the humid tropics, the presence of clay-rich soils and high rainfall intensities result in generation of saturation overland flow where hardpans or impeding horizons exists near the surface. Thus with forest conversion to pastures, the impeding layer could be extended to the surface due to compaction, and thus increasing the occurrence of infiltration-excess overland flow and thus increased discharges. However, as highlighted by Cappelaere et al. (2009), 
finer process understanding at various spatial and temporal scales is still needed to explain the observed surface fluxes and improve future water management scenarios. Results presented in this paper are part of a project which aims to develop a decision support tool to alleviate land use intensification associated problems in Southern Amazonia. These losses of ecosystem services include loss of natural vegetation and associated ecosystem functions in the global and regional climate system, increasing emissions of greenhouse gases (GHG), and the reduction of livelihoods. This paper examines the rainfall runoff relationships and the various controls of catchment hydrology in micro-catchments. An important source of variability in the study catchments is the contrasting land use. The study focuses on a natural forest catchment and a pasture catchment in which the original forest vegetation has been removed and replaced with Brachiaria brisanta grass for intensive cattle rearing. To reduce the effect of spatial variability typical for the medium-sized and large basins, this study focuses on micro-catchments that are less than $1 \mathrm{~km}^{2}$ in spatial extent.

The objective of the study was to understand how stream flow is conditioned by microclimate, precipitation pattern, land cover and soil properties, amongst other catchment properties. The catchment physiographic characteristics were examined in relation to observed stream flow dynamics for selected rain storms and also how these are likely related to current land use and land cover patterns. This paper contributes to the understanding of process hydrology by characterizing the hydrological behavior of small headwater catchments in active deforestation zones of Southern Para State on the south east of the Amazonia.

Our central hypothesis is that clearing for pastures and agricultural development leads to increased flashiness of catchment discharge dynamics and also reduces dry season flows. By quantifying the water balance components of the selected catchments, we test the infiltration trade-off hypothesis for tropical environments and the applicability of the linear reservoir concept. The following sections provide a description of the studied catchment; details of the chosen methodologies for the analysis; and an overview of the results. 


\subsection{Study site and methods}

\subsubsection{Location and Physical Characteristics}

The experimental catchments are located within the boundaries of Fazenda Paraiso $\left(7.042^{\circ} \mathrm{S}, 55.385^{\circ} \mathrm{W}\right)$, which is about $5 \mathrm{~km}$ from the town of Novo Progresso in Southern Para Brazil (Fig. 4.1), and situated in the watershed of the Jamanxim River, one of the major southern sub-tributaries of the Amazon River. The climate is humid tropical with a rainy season from November to May and a dry season that extends from June to October. Mean annual precipitation averages $1900 \mathrm{~mm}$. Figure 4.2 shows typical soil profiles in the study area, and tables 4.1 and 4.2 show the basic soil profile horizon characteristics for the two study catchments. The dominant soils are Lixisols (Haplustox / Latossolo vermelho-amarelo distrófico (Brazil classification)) with sandy clay texture (mean soil texture of $55 \%$ sand, $2 \%$ silt, and $43 \%$ clay) (Soil Survey Staff, 1999). Lixisols are related to the Oxisol order of the U.S. Soil Taxonomy. The pasture catchment with an area of 24 ha is covered by pasture grass (Brachiaria brisanta). The forest catchment with an area of 93 ha is located approximately $1.5 \mathrm{~km}$ from the pasture catchment, on the south eastern fringe of the farm is generally a natural forest with existing signs of vegetation/tree regrowth and the existence of tree logging sites.

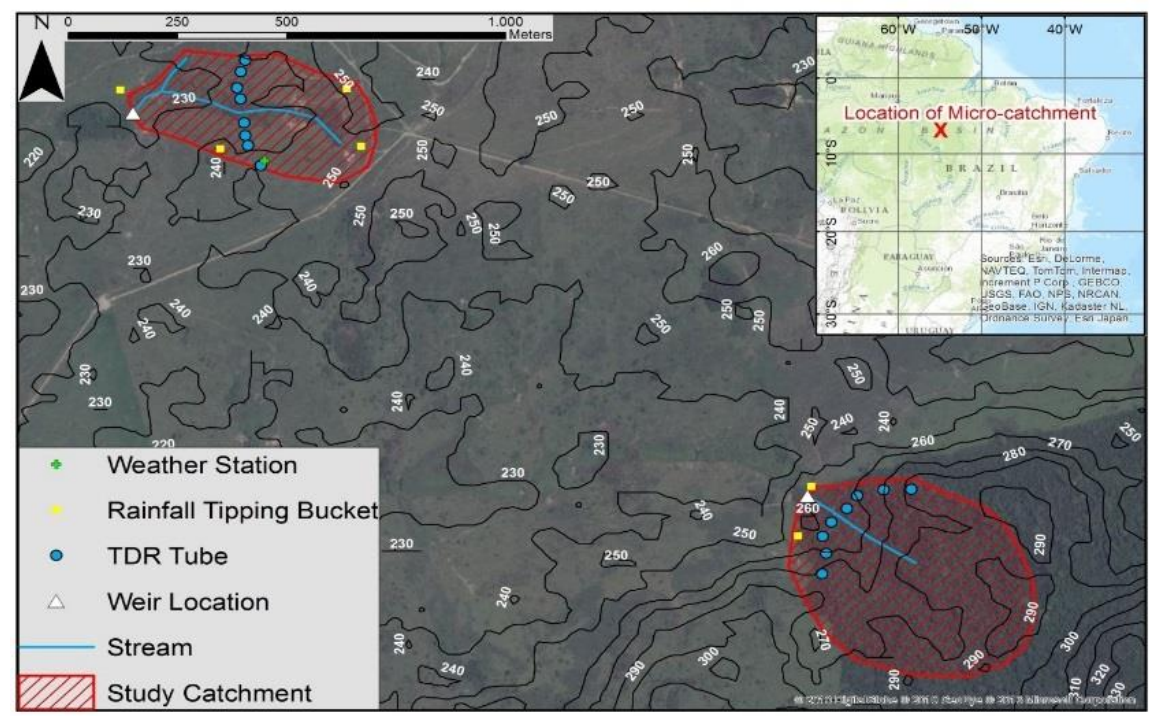

Figure 4.1 Study area location and study catchments instrumentation. 
Table 4.1 Soil horizon characteristics in the study catchments

Pasture: Clayic Lixisols

\begin{tabular}{|c|c|c|c|c|c|c|c|}
\hline $\begin{array}{l}\text { Horizon } \\
\text { Symbol }\end{array}$ & Depth $(\mathrm{cm})$ & Texture & Color & $\begin{array}{l}\text { Bulk Density } \\
(\mathrm{g} / \mathrm{cm} 3)\end{array}$ & Structure & Roots & Other features \\
\hline A & $0-5$ & Sandy Loam & 10YR 3/11 & 1.2 & $\begin{array}{l}\text { Block sub } \\
\text { angular } \\
\text { moderate }\end{array}$ & $\begin{array}{l}\text { Few } \\
\text { Very fine }\end{array}$ & - \\
\hline $\mathrm{E}$ & $5-70$ & $\begin{array}{l}\text { Sandy clay } \\
\text { loam }\end{array}$ & $2.5 Y 6 / 4$ & 1.1 & $\begin{array}{l}\text { Block sub } \\
\text { angular } \\
\text { moderate }\end{array}$ & $\begin{array}{l}\text { Very few } \\
\text { Very fine } \\
\text { none }\end{array}$ & - \\
\hline \multirow[t]{2}{*}{$\mathrm{Bt}$} & 70-103 & Clay loam & $2.5 Y 7 / 3$ & & & & \\
\hline & & & & 1.1 & $\begin{array}{l}\text { Block sub } \\
\text { angular } \\
\text { moderate }\end{array}$ & & - \\
\hline
\end{tabular}

Forest: Albic Lixisols

\begin{tabular}{|c|c|c|c|c|c|c|c|}
\hline $\begin{array}{l}\text { Horizon } \\
\text { Symbol }\end{array}$ & $\begin{array}{l}\text { Depth } \\
\text { (cm) }\end{array}$ & Texture & Color & $\begin{array}{l}\text { Bulk Density } \\
\left(\mathrm{g} / \mathrm{cm}^{3}\right)\end{array}$ & Structure & Roots & Other features \\
\hline A & $0-7$ & Sandy Loam & $\begin{array}{l}10 Y R \\
2 / 2\end{array}$ & 1.1 & $\begin{array}{l}\text { Block sub } \\
\text { angular } \\
\text { moderate }\end{array}$ & $\begin{array}{l}\text { Few } \\
\text { Very fine }\end{array}$ & - \\
\hline $\mathrm{E}$ & $7-47$ & Sandy clay loam & $\begin{array}{l}10 Y R \\
4 / 3\end{array}$ & 1.3 & $\begin{array}{l}\text { Block sub } \\
\text { angular } \\
\text { moderate }\end{array}$ & $\begin{array}{l}\text { Very few } \\
\text { Very fine }\end{array}$ & - \\
\hline $\mathrm{Bt}$ & $47-60$ & Clay loam & $\begin{array}{l}2.5 Y \\
5 / 3\end{array}$ & 1.4 & $\begin{array}{l}\text { Blocky sub } \\
\text { angular } \\
\text { moderate }\end{array}$ & None & - \\
\hline Bvm & $60-$ & Plinthic layer & & - & - & - & Impenetrable \\
\hline
\end{tabular}

Table 4.2 Saturated Hydraulic conductivity $(\mathrm{cm} / \mathrm{hr}$ ) measured at two depths and three different positions in the study catchments.

\begin{tabular}{cccc}
\hline Catenal Position & Measurement Depth & Pasture & Forest \\
\hline Upslope & $25 \mathrm{~cm}$ & 0.339 & 1.53 \\
& $40 \mathrm{~cm}$ & 1.66 & 0.915 \\
& & & \\
Middle Slope & $25 \mathrm{~cm}$ & 0.39 & 7.72 \\
& $40 \mathrm{~cm}$ & - & 4.34 \\
Valley Bottom & $25 \mathrm{~cm}$ & 0.77 & 6.01 \\
& $40 \mathrm{~cm}$ & 0.95 & 7.88 \\
\hline
\end{tabular}




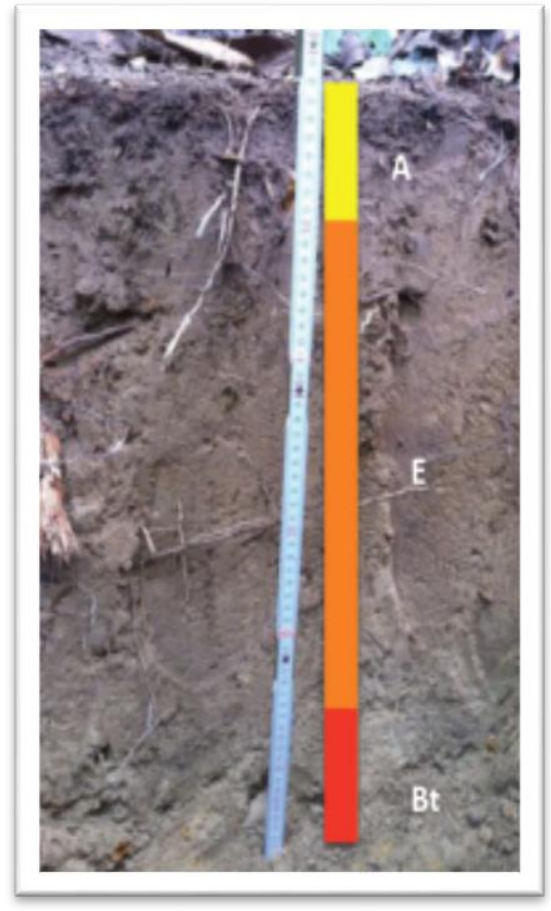

Forest: Albic Lixisol

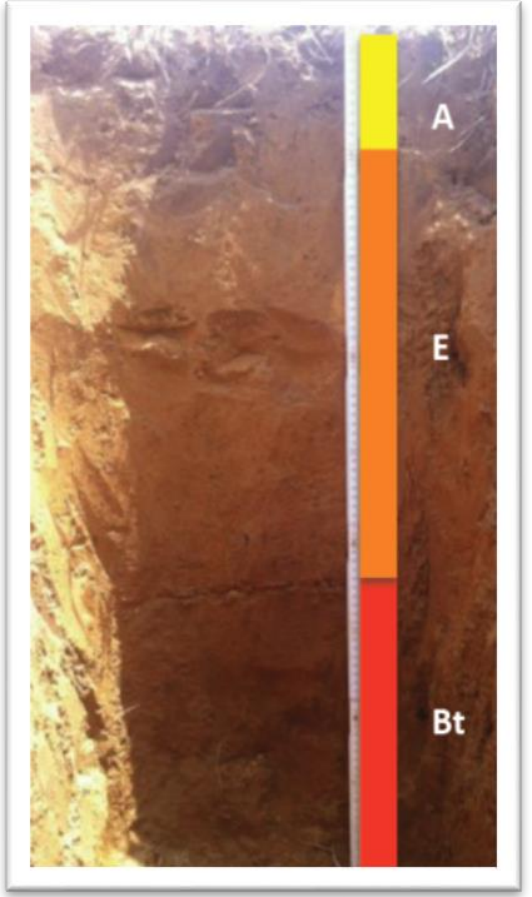

Pasture: Clayic Lixisol

(Photo: J. Rebola-Lichtenberg)

Figure 4.2 Typical soil profiles in the two study catchments.

\subsection{Methods}

\subsubsection{Rainfall and weather data}

In order to capture the rainfall variability within the catchments, a network of tipping bucket rain gages was installed. In the pasture catchment, four tipping buckets with data loggers (Tinytag, Gemini, UK) were installed. Three tipping buckets were at the forest catchment. Each of the tipping buckets has a resolution of $0.2 \mathrm{~mm}$, and rainfall was recorded at 10 minute intervals. A weather station was installed within the pasture catchment with sensors to measure total solar radiation, net solar radiation, temperature, relative humidity, wind speed and direction and rainfall. Data was logged at a 10 minute time interval using two GP1 loggers. Reference evapotranspiration was quantified using the Penman-Monteith equation following the procedure presented by Allen et al. (1998). 


$$
\mathrm{ET}_{\mathrm{o}}=\frac{0.408 \Delta\left(\mathrm{R}_{\mathrm{n}}-\mathrm{G}\right)+\gamma \frac{900}{\mathrm{~T}+273} \mathrm{u}_{2}\left(\mathrm{e}_{\mathrm{s}}-\mathrm{e}_{\mathrm{a}}\right)}{\Delta+\gamma\left(1+0.34 \mathrm{u}_{2}\right)}
$$

where:

ETo reference evapotranspiration [mm/day], Rn surface net radiation [MJ/m²/day], G soil heat flux density [MJ m${ }^{-2}$ day $\left.^{-1}\right], \mathrm{T}$ mean daily air temperature at $2 \mathrm{~m}$ height $\left[{ }^{\circ} \mathrm{C}\right]$, $\mathrm{u}_{2}$ wind speed at $2 \mathrm{~m}$ height [ $\mathrm{m} \mathrm{s}^{-1}$ ], $\mathrm{e}_{\mathrm{s}}$ saturation vapor pressure [kPa], $e_{a}$ actual vapor pressure $[\mathrm{kPa}], \mathrm{e}_{\mathrm{s}}-\mathrm{e}_{\mathrm{a}}$ saturation vapor pressure deficit [kPa], $\Delta$ slope vapor pressure curve $\left[\mathrm{kPa}{ }^{\circ} \mathrm{C}^{-1}\right]$, y psychrometric constant $\left[\mathrm{kPa}^{\circ} \mathrm{C}^{-1}\right]$. The grassland vegetation in the pasture catchments is perennial grasses with minimal seasonal growth stage variation and few scattered trees and shrubs. Therefore uniform Kc values were utilized to estimate actual evapotranspiration. Similarly, in the forest catchment a relatively uniform canopy of hardwood trees $20-30 \mathrm{~m}$ tall cover the entire catchment all year through and therefore a uniform $\mathrm{Kc}$ value was used to quantify actual evapotranspiration.

\subsubsection{Catchment Discharge}

At the catchment outlets, rectangular weirs were built and fitted with a DS 5X multiparameter sonde (OTT) which measured water level, electrical conductivity, $\mathrm{pH}$, turbidity, dissolved oxygen (LDO) and temperature at 15-minute intervals. The standard rectangular weir equation based on the Bernoulli equation was used to estimate catchment discharge (flow rate).

$Q=\frac{2}{3} C_{d} b(\sqrt{2 g}) h^{\frac{3}{2}}$

where:

Q: discharge over weir ( $\left.\mathrm{m}^{3} / \mathrm{s}\right)$; Cd: discharge coefficient; b: weir length $(\mathrm{m})$; $\mathrm{h}$ : head on weir $(m)$

In order to understand the temporal dynamics in the hydrological response of the study catchments, the rainfall-run off relationships exhibited in the obtained discharge data for the period January 2013 to the end of May 2013 were examined. This coincides with the rain season in the study area. A few rainy storms were missed in November and December due to delays in field equipment installation. 


\subsubsection{Soil Moisture}

From a hydrologic viewpoint, soil moisture controls the partitioning of rainfall into runoff and infiltration and therefore has an important effect on the runoff behavior of catchments (Aubert et al., 2003). Time domain reflectometry (TDR) was used to monitor soil moisture dynamics. The TDR system was used to measure volumetric water content on a weekly basis, with TECANAT access tubes installed to a depth of $200 \mathrm{~cm}$ in two transects in each catchment. The study catchments feature a toposequence of landscape positions from a gently sloping upper plateau, a middle slope and a low-gradient valley bottom. Access tubes were installed along this toposequence and thus the measured soil moisture represents water content dynamics along this toposequence. A TRIME-PICO T3 probe (IMKO Micromodultechnik $\mathrm{GmbH}$, Ettlingen, Germany) was used to take measurements of volumetric water content at the following soil depth intervals: 0-20, 20-40, 40-60, 60$80,80-100,100-120,120-140,140-160$ and $180-200 \mathrm{~cm}$. Since the TRIME probe measures water content in an elliptical field, two measurements were taken at each depth increment and averaged to account for local and spatial variability in water content.

Detailed hydraulic properties (saturated hydraulic conductivity, Ks, and bulk density, BD) characterizing these catchments were also quantified. A constant head permeameter (Amoozemeter) designed by Amoozegar (1989) for in situ measurements above the water table was used to estimate hydraulic conductivity. This was done by augering a borehole at $25 \mathrm{~cm}$ depth and at $40 \mathrm{~cm}$ depth, establishing a constant water head in the hole and calculating Ks from the steady-state infiltration rate using the Glover equation (Amoozegar, 1989b). Particle size distribution of the soils was measured using the pipette method (Gee and Bauder, 1986) after chemical dispersion and removal of organic matter and carbonate contents. Soil bulk density was estimated using undisturbed samples dried in an oven at $105^{\circ} \mathrm{C}$ (Burke et al., 1986). Soil particle density was measured in the laboratory using the pycnometer method of Blake and Hartge (1986) and total porosity was determined from bulk density and particle density values. 


\subsubsection{Hydrograph separation}

In line with procedures utilized by Recha et al. (2012), for the study period, the stream hydrographs were normalized using the approximate catchment area in order to allow a comparison of the catchments. Using discharge data, the Runoff Ratio (RR) was quantified as the ratio of total runoff to total rainfall. The discharge data were further analyzed using hydrograph separation techniques implemented in the Web GIS-based Hydrograph Analysis Tool (WHAT) using the recursive digital filter method for base flow separation (Lim et al. 2005; Lim et al. 2010). From this analysis, base flow and storm flow components of the runoff ratio (RRBF and RRSF as the ratio of total base flow and storm flow to total rainfall, respectively) were obtained. The base flow index $(\mathrm{BFI})$ is the ratio of base flow to total discharge (Bloomfield et al., 2009). Flow duration curves were calculated to compare the differences in high, low, and median flows across the catchments (Vogel and Fennessey 1994). The Baker et al. (2004) method was used to estimate catchment flashiness indices.

\subsubsection{Water Balance}

Using the monitoring data, a water balance for each study catchment can be constructed as follows:

$P=R+E T+\Delta S$

where $P$ the rainfall, $R$ is the surface water flow out of the catchment, ET is the evapotranspiration, and $\Delta S$ is the water content change in the unsaturated zone and recharge to saturated zone. $\Delta S$, thus, includes lateral as well as vertical groundwater losses and gains from the catchment as well as error in estimating all mass balance components on the right-hand side of Equation 3. Due to logistical difficulties and equipment shortages, aquifer recharge could not be quantified and therefore in the water balance this term is lumped together with unsaturated zone water content.

\subsection{Results and discussion}

In this section, results obtained from the two study catchments are presented. The rainfall characteristics, pattern and variability between the two sites and the major soil profile characteristics are analyzed. After this, results of measured soil moisture 
dynamics over the study period, stream discharge characteristics and quantified actual evapotranspiration variations in the study catchments are presented and discussed.

\subsubsection{Precipitation characteristics}

Figure 4.3 shows the daily rainfall amounts in each catchment. During the study period (December 2012 to May 2013) the pasture catchment received $1254 \mathrm{~mm}$ of rainfall while $1190 \mathrm{~mm}$ was recorded in the forest catchment. Given the convective rainfall typical of the tropical regions, the spatial variability in daily rainfall amounts was investigated by comparing average daily accumulations recorded in the pasture site with those recorded by tipping buckets in the forest site. A scatter plot of the two sampling locations is shown in Figure 4.4. This figure shows high coefficient of determination $\left(r^{2}=0.84\right)$ between these two sites. Considering the small size of the study catchments this analysis can provide confidence of using rainfall from only one site and apply to the other site. Rain events occur simultaneously at both locations. Most of the rainstorms are mid-afternoon storms of varying durations and peak intensities of $20 \mathrm{~mm} / 10 \mathrm{~min}$ and $23 \mathrm{~mm} / 10 \mathrm{~min}$ were observed in the pasture and forest catchments, respectively. Data analysis also shows the typical short, intense nature of tropical storms with mean storm duration of about 2 hours.

\subsubsection{Soil Profile Characteristics}

The forest catchment had a markedly lower mean bulk density $\left(1.2 \mathrm{~g} \mathrm{~cm}^{-3}\right)$ than the pasture catchment $\left(1.42 \mathrm{~g} \mathrm{~cm}^{-3}\right)$. This difference may be attributed to the higher root penetration and lack of compaction by the cattle in the forest catchment. The forest catchment exhibited a blocky structure while the pasture catchment had mainly blocky and platy structure. The platy structure in the pasture originates from compaction as a consequence of the operations for deforestation or cattle trampling. 


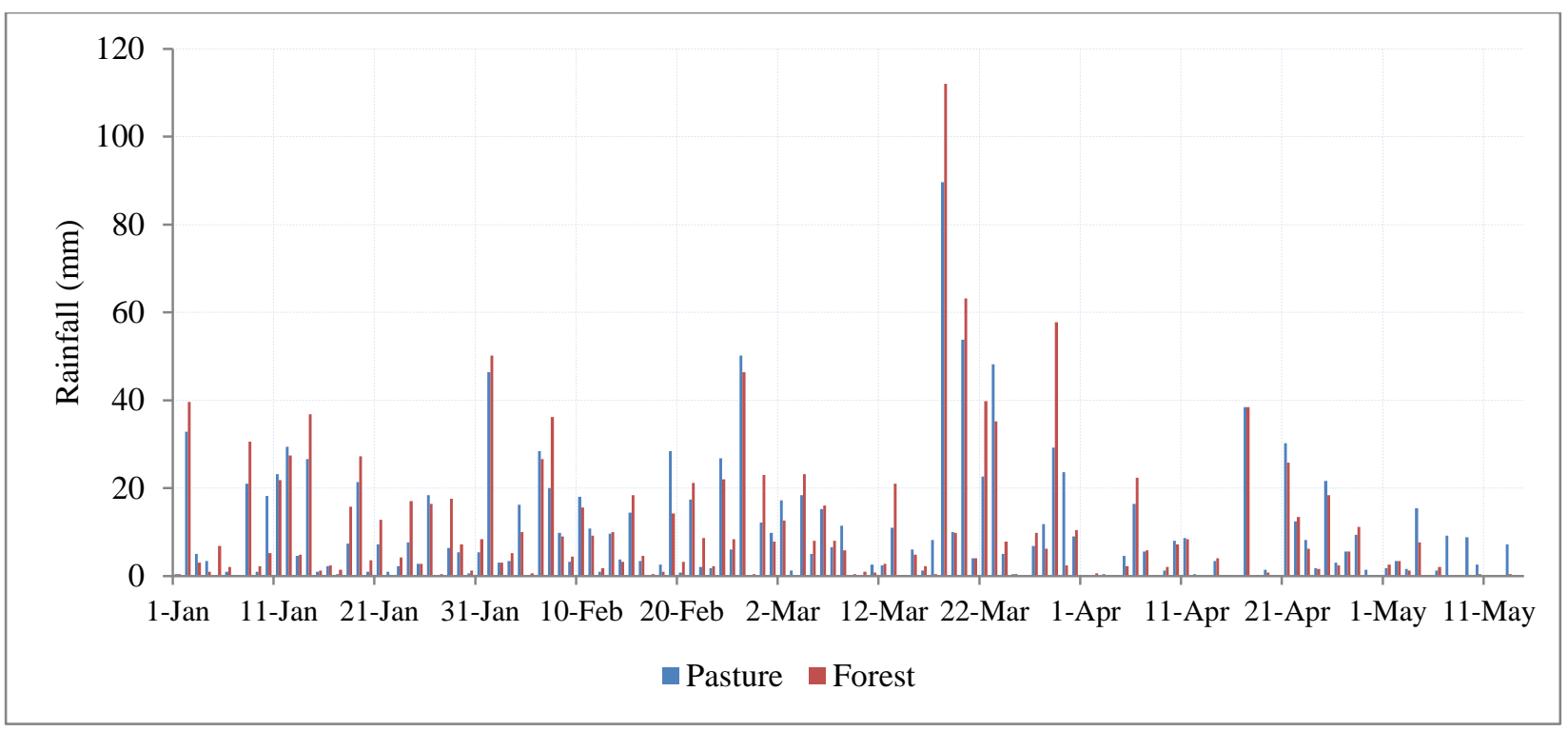

Figure 4.3 Daily rainfall in the two study catchments (average of the tipping buckets).

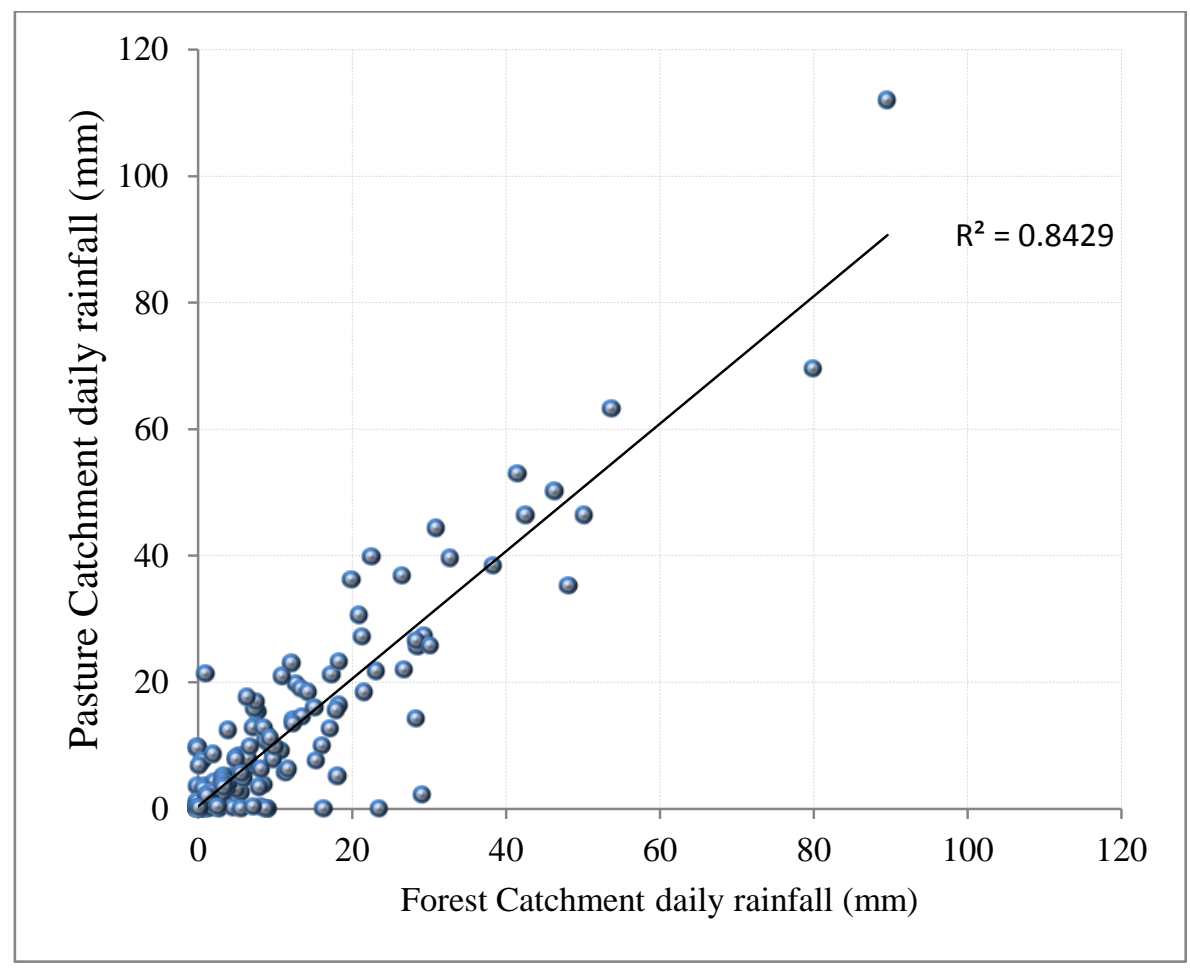

Figure 4.4 Correlation between daily rainfall data from Forest and Pasture catchments

Results from this study show that the saturated hydraulic conductivity was relatively lower in the pasture catchment compared to the forest catchment. The low $\mathrm{K}_{\text {sat }}$ values in the pasture catchment can be an indication of the absence of a well-defined macro pore structure. The forest catchment had more than six times higher rate of saturated 
hydraulic conductivity than the pasture (Table 4.2). That means moderately rapid infiltration and subsequently lower probability of runoff. Most probably the higher organic matter content and the lower bulk density in the forest favor the infiltration of water. Even though our study was only limited to two depths of measurements $(25 \mathrm{~cm}$ and $40 \mathrm{~cm}$ ), these results show relative anisotropy in $\mathrm{K}_{\text {sat }}$ with depth. Strong anisotropy has also been reported on oxisols in south western Amazonia (Elsenbeer et al., 1999).

\subsubsection{Soil Moisture variation}

From weekly soil moisture measurement data, the average soil moisture content remained in the $15-35 \%$ range during most of the measurement period. While soil moisture measurements were done on a weekly basis, the lack of large peaks in soil moisture contents at both sites even one day after large rainfall events may suggest that there is rapid drainage in the soil profiles at these two sites. Drying out was also observed beginning at the top and decreasing with depth. As shown in Figure 4.5, soil moisture content variability between the two catchments was generally limited. The pasture catchment exhibited lower hydraulic conductivity, compared to the forest catchment. Therefore, any greater surface inputs (rainfall) in the pasture catchment compared to the forest are likely offset by this difference in hydraulic conductivity. There is a general similarity in mean soil moisture contents between these two catchments. Maybe the drainage processes in these catchments behaves in similar ways and the soil profiles drain rapidly. This was observed by Hodnett et. al (1995) in central Amazonia catchments. Surface compaction in the pasture catchment can be a reason for a delay in replenishment of soil moisture stores while in the forest catchment while in the forest catchment, water uptake by plant roots influence profile moisture changes. 

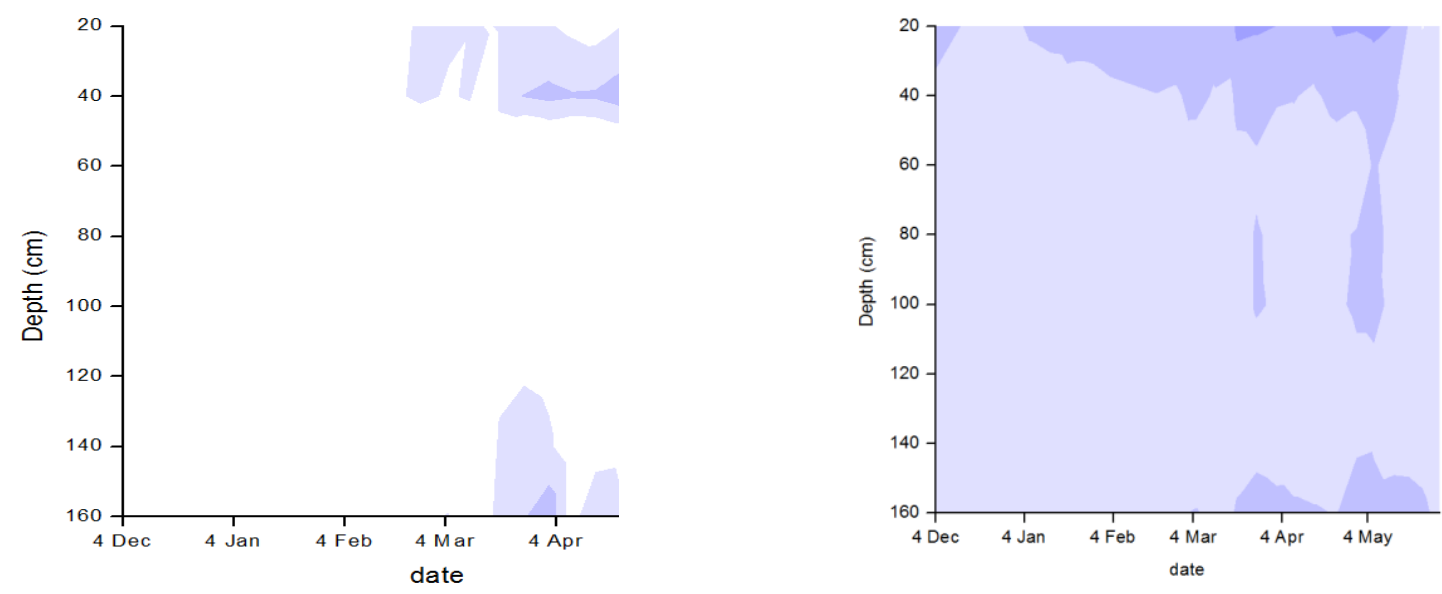

Upslope
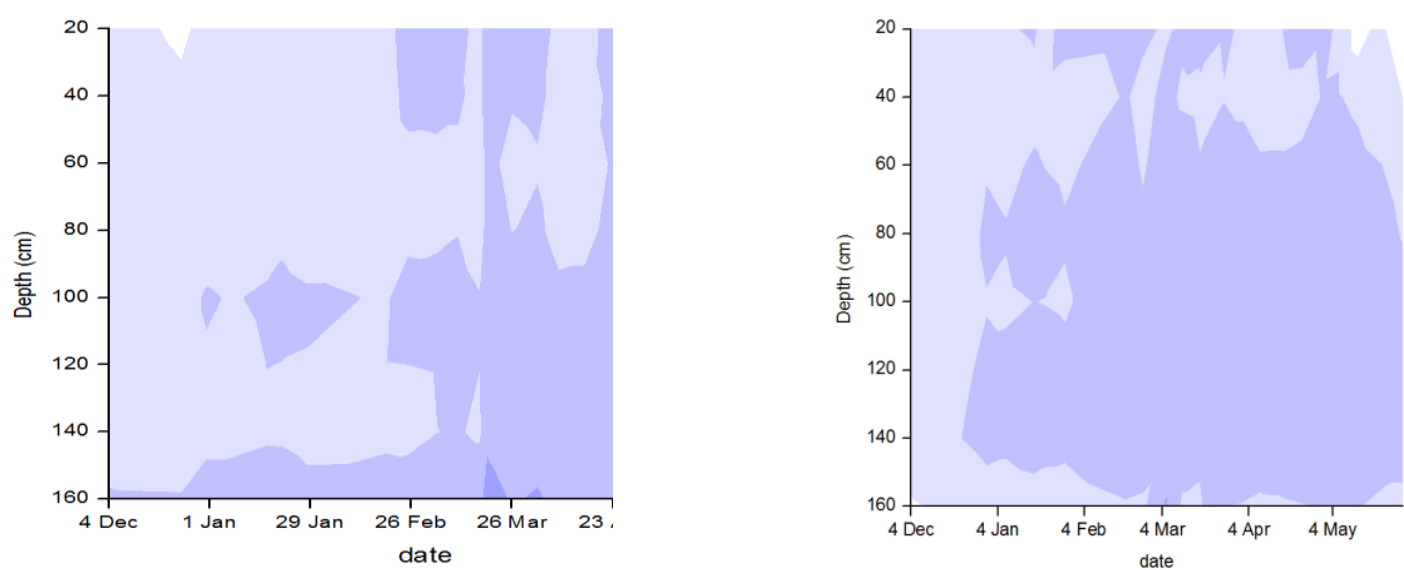

Middle Slope
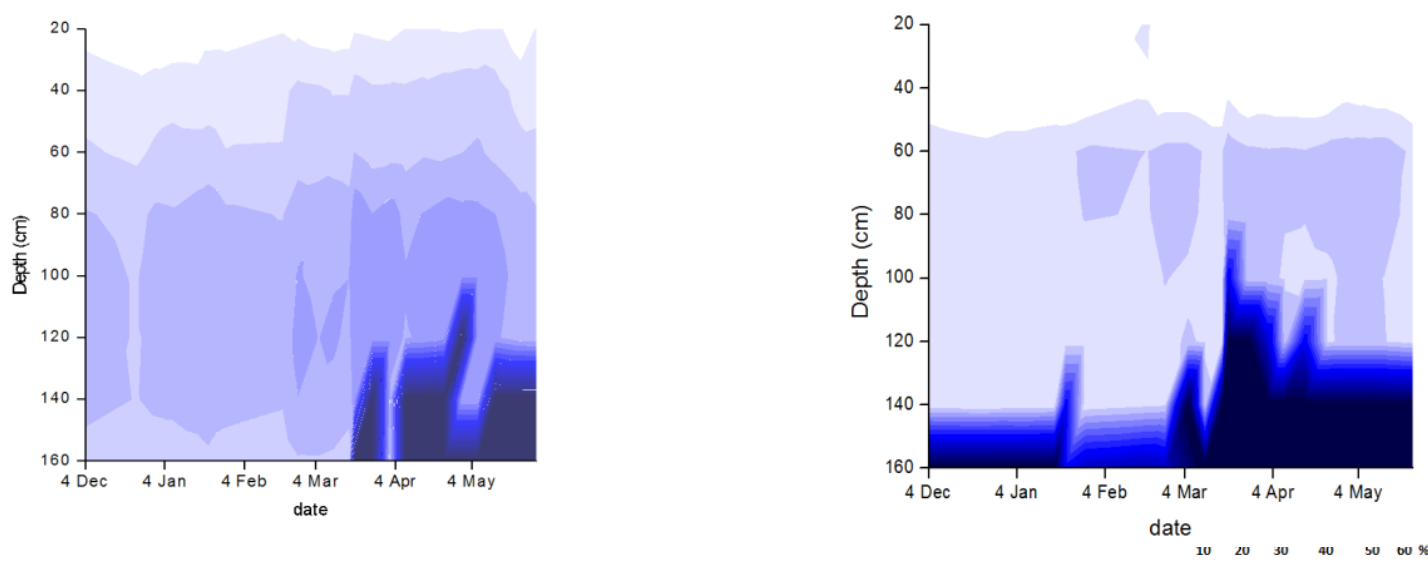

Valley

bottom

Figure 4.5 Time series of soil moisture (\% vol.) at three catena positions in the forest and pasture catchments.

In the forest site, the soil profile was generally shallower, with bedrock at about $50 \mathrm{~cm}$ and presence of hardpan horizon was also observed. This may limit soil water reservoirs and also the hardpan horizon also promotes subsurface flow generation. The high base flow values observed in the forest catchment also support this 
observation. The low water contents in the forest may also suggest the great influence of root water extraction in the forest site. This trend was also observed by Hodnett et al. (1995), who noted the great variation in soil moisture content between pasture and forest catchments in the Amazon.

As expected, Figure 4.5 also shows a general increase in soil moisture from the upslope to the bottom slope. Because the soil moisture measurements were manually done on weekly basis and at times suitable for field work, the highest soil moisture content measured at both sites is likely to be between the saturation point and field capacity. In the pasture catchment the average Volumetric Moisture Content (VMC) was about $21 \%$ while in the forest catchment this was about $24 \%$. These low VMC are typical in these lixisols which behave like sands in terms of water movement at low tensions but hold water like clay at high tensions (Sanchez (1976) in Hodnett et al. (1995).

\subsubsection{Catchment Discharge}

Figure 4.6 shows the peak daily stream flows at the 2 sites and Figure 4.7 shows the normalized daily discharges. During the study period, mean and peak discharges were higher in the pasture catchment compared to the forest catchment. The mean discharge was $8 \mathrm{~mm} /$ day in the pasture catchment and $5 \mathrm{~mm} /$ day in the forest catchment and the peak discharge was $49 \mathrm{~mm} /$ day in the pasture catchment and 20 $\mathrm{mm} /$ day in the forest catchment. These results are similar to those obtained by Trancoso et al. (2007) in relatively similar catchments in the Amazon. The results show that land cover alterations impact on catchment water storage properties and this has direct effects on water quantity and water quality related ecosystem services.

The relative hydrological behavior of the study catchments in a wet season as shown through the FDCs (Figure 4.8) provides evidence of the major rainfall runoff control processes. The Flow Duration Curves indicated that the pasture catchment exhibits almost $50 \%$ high flows ( 0 to 5 th percentiles on FDC) than the forest catchment. The pasture catchment discharges more water at all percentages of time that the discharge is equaled or exceeded. For example, a $10 \mathrm{~mm} /$ day runoff is equaled or exceeded in the pasture catchment for $30 \%$ of the time while in the forest it is exceeded only for $10 \%$ of the time. Differences between the FDC's are limited during the low flow 
periods. To illustrate characteristics of individual flow events in the study catchments, two hydrographs were plotted for the rainfall storm of March $23^{\text {th }} 2013$ (Figure 4.9). The runoff response was much faster in the pasture catchment with an average lag time of 25 minutes compared to 60 minutes for the forest catchment. In the forest catchment, the hydrograph shows a delayed response suggesting that sub surface flow and subsequent overland flow on saturated areas were important processes. As explained by Suryatmojo et al. (2013), physical catchment parameters such as slope, shape, main-stream slope and drainage density affect stream flow and influence the shape of the hydrograph through catchment storage, runoff speed, infiltration and soil water content. While the study catchments display similar patterns, when the flows begin to decline with the onset of the dry season, the flow of forest catchment decreases first.

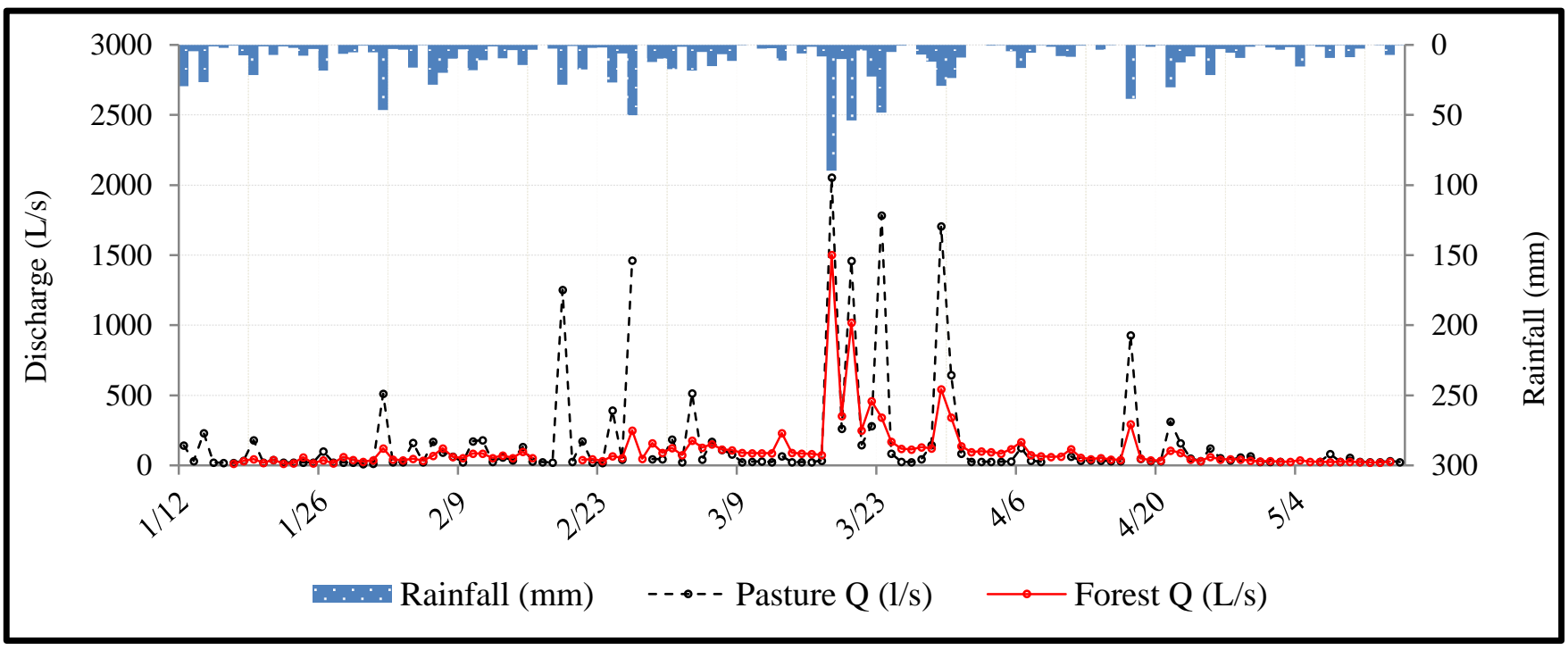

Figure 4.6 Peak discharges and areal average rainfall in the study catchments.

Hydrologic indices calculated from discharge data for these two catchments are shown in Table 4.3. Runoff ratios were significantly higher in the pasture catchment $(0.79)$ than the forest catchment (0.46). However base flow contribution to stream flow was higher in the forest catchment (0.76) compared to the pasture (0.63). Table 4.3 shows a water balance for the two catchments and for almost similar rainfall totals during the study period, discharge normalized to catchment area was higher in the pasture catchment $(992 \mathrm{~mm})$ compared to the forest catchment $(584 \mathrm{~mm})$. The average daily 
stream flow for the pasture catchment was $9.0 \mathrm{~mm}$ while it was $5.6 \mathrm{~mm}$ for the forest catchment.

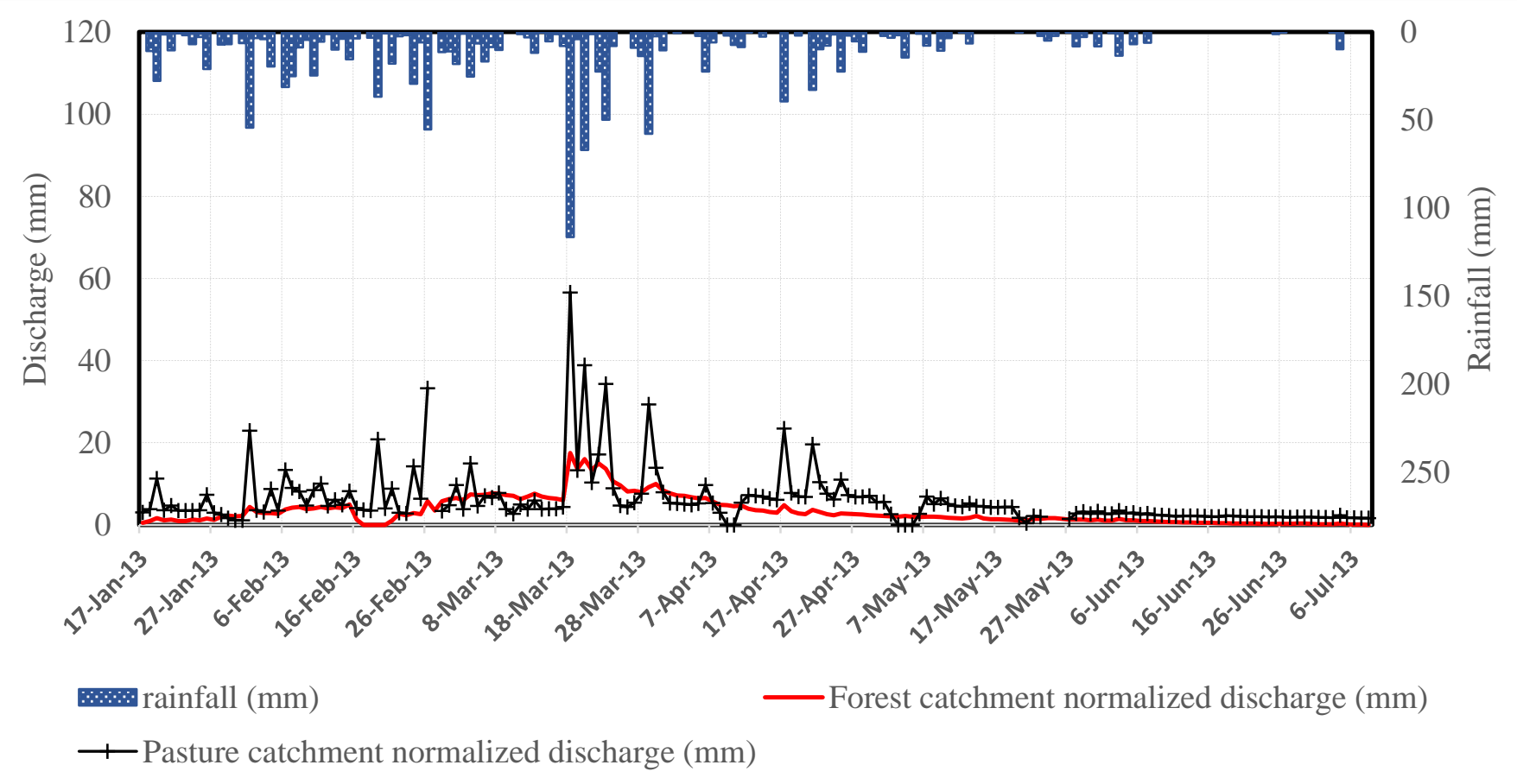

Figure 4.7 Normalised discharges and areal average rainfall in the study catchments.

For selected representative rainstorms in the study catchments, the hydrographs are shown in Figure 4.10 (a-c) for the two study catchments. For the rainstorm on February $26^{\text {th }} 2013,46 \mathrm{~mm}$ of rain produced $7 \mathrm{~mm}$ discharge at peak discharge rates of 0.24 $\mathrm{mm} / 10 \mathrm{~min}$ in the forest catchment while $55 \mathrm{~mm}$ of rain produced $31 \mathrm{~mm}$ of runoff at peak discharge rates of to $4 \mathrm{~mm} / 10 \mathrm{~min}$ in the pasture catchment. The runoff coefficient for the pasture site was almost five times higher than for the forest catchment. The March $18^{\text {th }}$ rainstorm $(120 \mathrm{~mm}$ ) produced $55 \mathrm{~mm}$ of runoff in the pasture catchment and on the same day $121 \mathrm{~mm}$ of rainfall produced only $26 \mathrm{~mm}$ runoff in the forest catchment. Similarly, on April $17^{\text {th }}, 39 \mathrm{~mm}$ of rain produced $23 \mathrm{~mm}$ runoff in the pasture while $38 \mathrm{~mm}$ of rain produced only $6 \mathrm{~mm}$ discharge in the forest catchment. These hydrologic signatures show the relationship between total precipitation, base flow and runoff, with land cover playing an important role. As outlined by Bruijnzeel (2006), that even though it can be argued that a direct comparison of the catchments may lead to biased results because of inherent topographic differences between the two areas, it is pertinent to note that the relative size of the topographically controlled area potentially generating SOF was larger for 
the forest catchment than for the pasture. Thus, the larger peak flows observed for the pasture catchment cannot be attributed only to intrinsic differences in catchment topography. An increase of runoff in the pasture could mainly be attributed to an increase in infiltration excess (Hortonian) overland flow. As stated by Elsenbeer (2001) and Niedzialek and Ogden (2010), the observed runoff properties are typical of many tropical catchments with dominant sources of water at the event scale being rapid lateral transport of water.

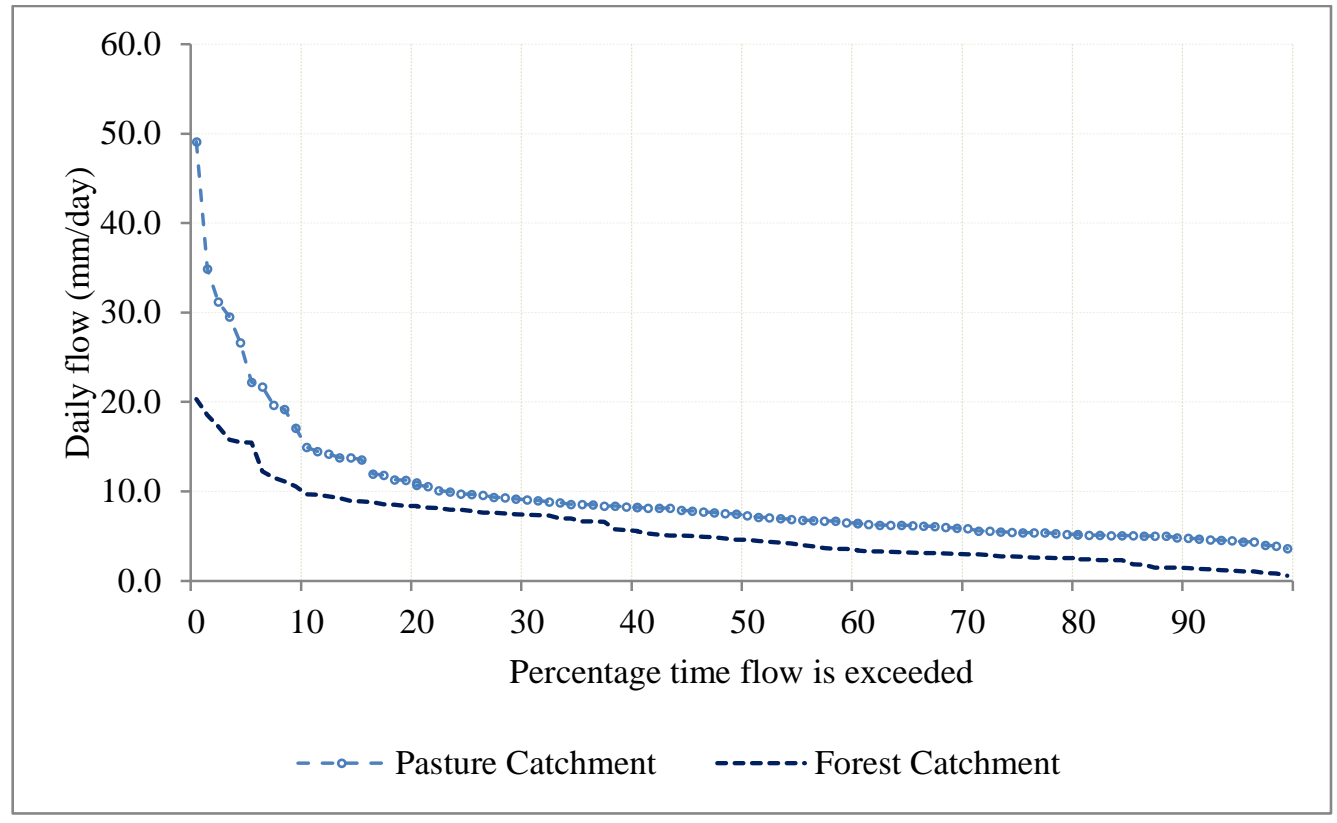

Figure 4.8 Flow duration curves for daily discharge data from the study catchments.

Most of the rainfall intensities in the pasture exceeded the $\mathrm{K}_{\text {sat }}$ values near the surface and this may mean that there are high frequencies of Hortonian overland flows occurring at this site. Moraes et al. (2006) observed similar results in pasture catchments in Eastern Amazonia. The higher discharges of the pasture catchment could be explained by the compaction of soil upper layers by cattle grazing in the grasslands relative to the characteristics of soils in forest catchment. Compaction reduces rainfall infiltration, reducing groundwater replenishment and promotes surface flows (Bruijnzeel, 2004). As observed by Roa-Garcia (2011), the high flows in the pasture catchment also suggests a smaller water storage potential and higher surface runoff rates, related to grasslands that have less potential to store water than forests. In the forest catchments, higher Ks values were observed and usually forest soils are 
dominant in vertical flow paths (Williams et al., 1997). However, the occurrence of shallow impeding layers within the soil profiles in the forest result in increases in lateral flow contributing to stream flow. Overall results suggest that land use plays an important role in the observed hydrologic signatures. The overall water balance for the study catchments during the study period (Table 4) shows that in the forest site, $49 \%$ of all rainfall inputs were discharged from the catchment while for the pasture catchment this amounted to $79 \%$.

Table 4.3 Hydrological analysis and indices for the study catchments derived from rainfall runoff data for the period January to May 2013.

\begin{tabular}{|c|c|c|c|}
\hline Index & Pasture & Catchment & Forest Catchment \\
\hline Discharge $(\mathrm{mm})$ & & 992 & 584 \\
\hline $\mathrm{RC}^{\mathrm{a}}$ & & -71 & 0.466 \\
\hline Storm Flow (mm) & $\begin{array}{l}\text { Forest Catchment } \\
P(\mathrm{~mm})=122\end{array}$ & 1 & 154 \\
\hline $\mathrm{RC}_{\mathrm{SF}}^{\mathrm{b}}$ & $\operatorname{Imax}(\mathrm{mm} / 10 \mathrm{~min})=20.8$ & 36 & 0.123 \\
\hline Base Flow (mm) & $Q p(\mathrm{~mm} / 15 \mathrm{~min})=1.3$ & 1 & Pasture Catchment \\
\hline $\mathrm{RC}_{\mathrm{BF}}^{\mathrm{c}}$ & $\mathrm{Rc}=0.18$ & 35 & $C \quad P(m m)=120$ \\
\hline $\mathrm{BFI}^{\mathrm{d}}$ & & .626 & C $\quad \operatorname{Imax}(\mathrm{mm} / 10 \mathrm{~min})=18$ \\
\hline Flashiness Index & & .099 & $\begin{array}{l}Q \mathrm{Qp}(\mathrm{mm} / 15 \mathrm{mIn})=7.0 \\
\mathrm{Rc}=0.53\end{array}$ \\
\hline
\end{tabular}

These catchment discharge results could provide important information on water storage, fluctuation and runoff in these tropical head water catchments and the ability of the ecosystems in the headwaters to regulate water flows. The transformation of the headwater catchments from forests and wetlands to grasslands and pastures is most likely contributing to the reduction in their water regulation capacity, as indicated by this research, and ultimately impacts on the potential of management to influence dry season flows and storm flow attenuation.

Table 4.4 Results from a mass balance exercise with summations of rainfall, runoff, ET, and residuals over the study period (Jan-May 2013) for the study catchments.

\begin{tabular}{ccccc}
\hline Site & $\begin{array}{c}\text { Precipitation } \\
(\mathrm{P})(\mathrm{mm})\end{array}$ & $\begin{array}{c}\text { Discharge } \\
(\mathrm{Q})(\mathrm{mm})\end{array}$ & $\begin{array}{c}\text { Evapotranspiration } \\
\mathrm{ET}(\mathrm{mm})\end{array}$ & $\begin{array}{c}\text { Recharge and change } \\
\text { in Storage }(\Delta \mathrm{S})(\mathrm{mm})\end{array}$ \\
\hline $\begin{array}{c}\text { Pasture } \\
\text { Catchment }\end{array}$ & 1254 & 992 & 445 & -183 \\
\hline $\begin{array}{c}\text { Forest } \\
\text { Catchment }\end{array}$ & 1190 & 584 & 560 & 46 \\
\hline
\end{tabular}




\section{(a) $26^{\text {th }}$ February}
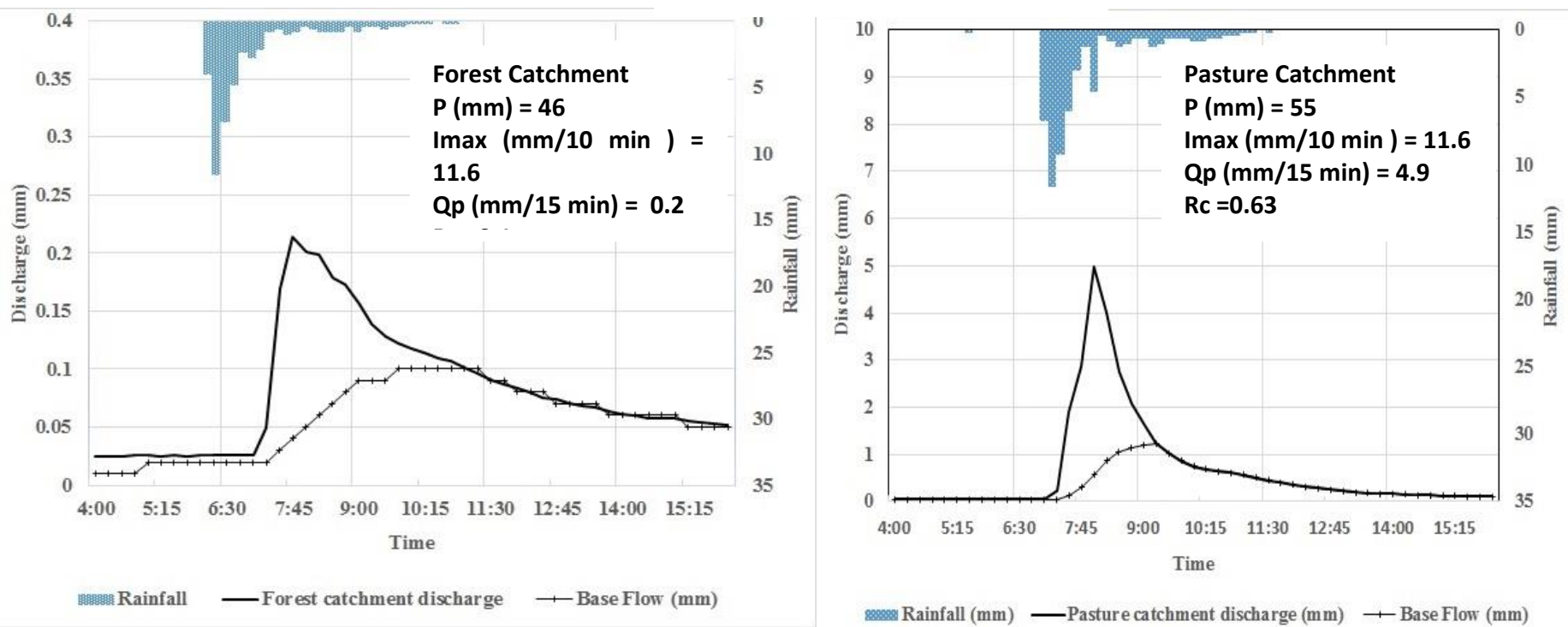

Rainfall (mm) —Pasture catchment discharge (mm) — Base Flow (mm)

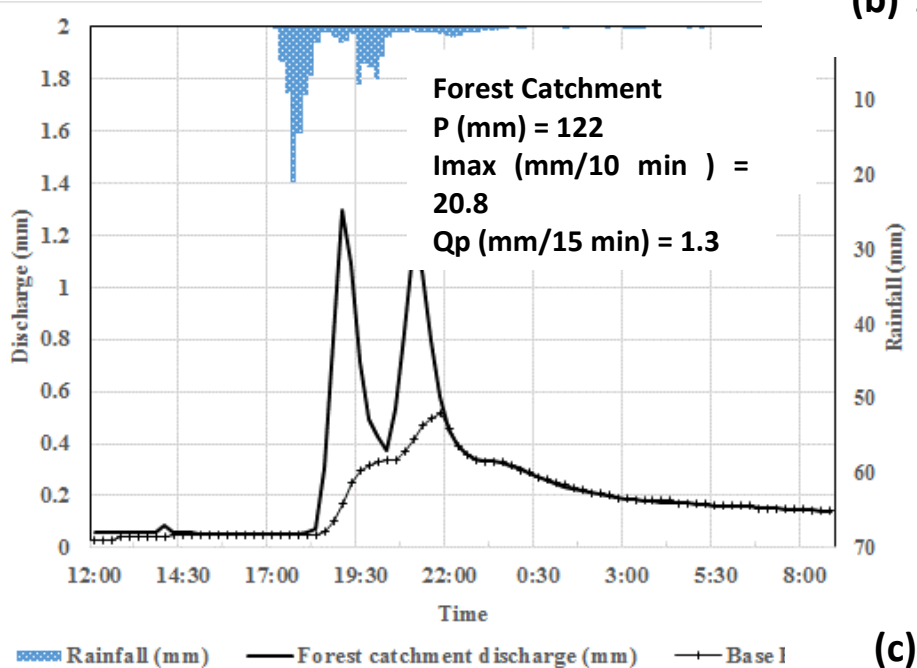

(b) $18^{\text {th }}$ March
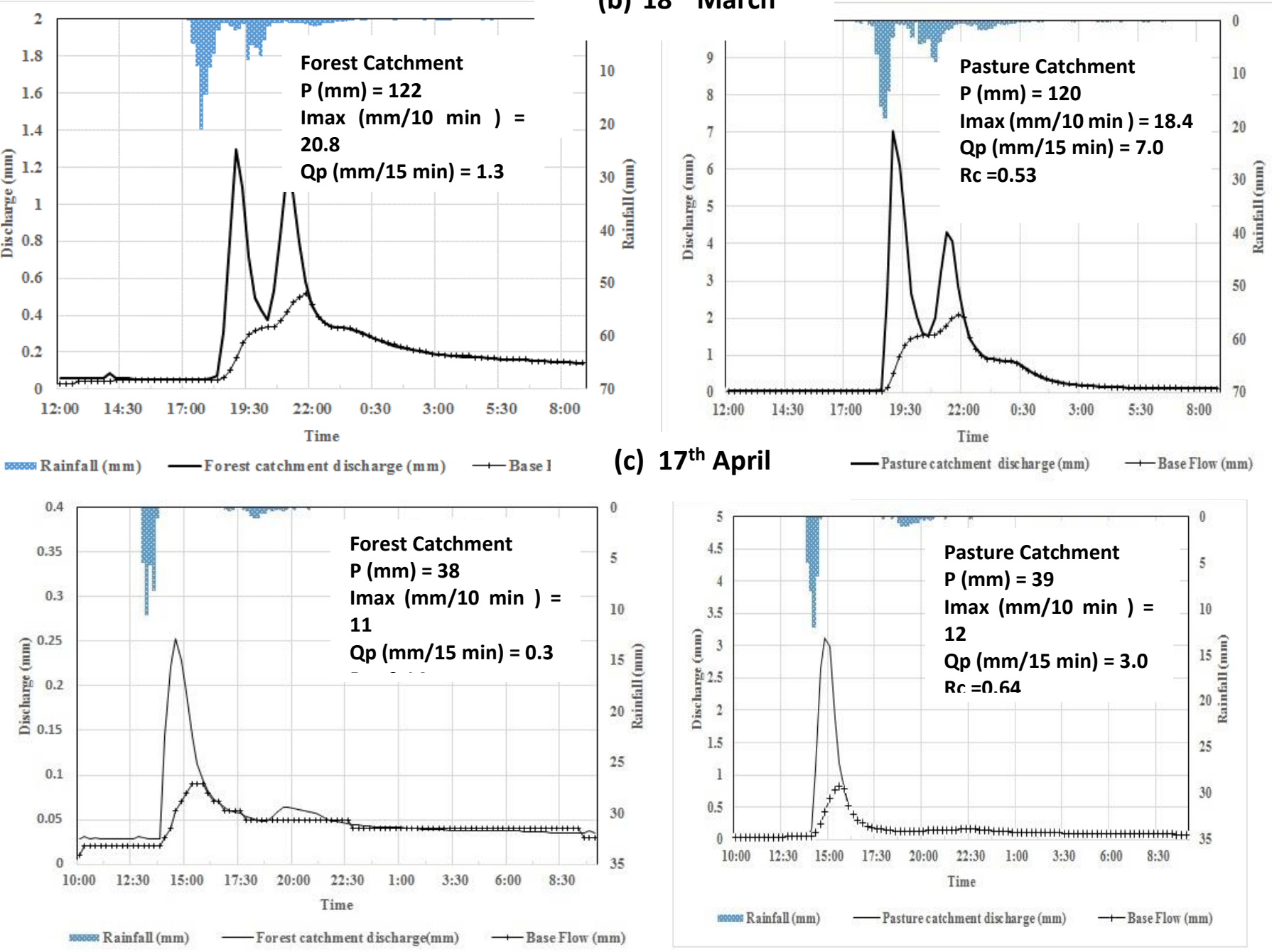

(c) $17^{\text {th }}$ April - Pasture catchment discharge $(\mathrm{mm}) \quad$-Base Flow (mm)

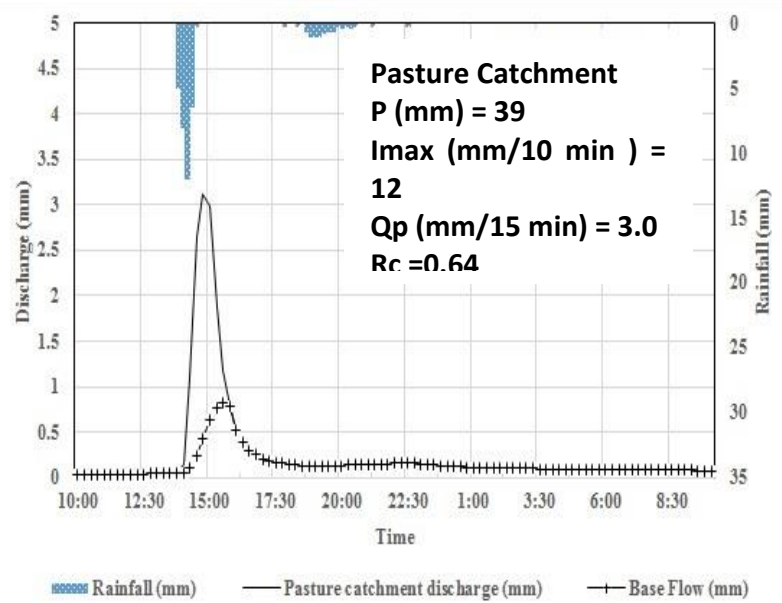

Figure 4.9 Example storm hydrographs from the two catchments. Precipitation $(P, \mathrm{~mm})$, maximum intensity of precipitation ( $\mathrm{mm} / 10 \mathrm{~min})$, Peak discharge $(\mathrm{Qp}, \mathrm{mm} / 10 \mathrm{~min})$, and runoff coefficient (RC). 


\subsubsection{Evapotranspiration}

Figure 11 shows time series of daily ET from each of the sites. The average ET in the forest catchment was $4.9 \mathrm{~mm} /$ day while in the pasture catchment the average daily ET was $3.6 \mathrm{~mm} /$ day. As asserted by Spracklen et al. (2012) that when forests are replaced by pasture or crops, evapotranspiration of moisture from soil and vegetation is often diminished, leading to reduced atmospheric humidity and potentially suppressing precipitation. Water budget calculation is a conceptual simple way to study the hydrological behavior of an ecosystem and provides a useful tool to assess the relative importance of the hydrological processes (Ingram, 1983; Price and Maloney, 1994). For the study catchments, water budget components for the study period are shown in Table 4.4. The quantification of ET using the semi empirical Penman-Monteith equation was based entirely on information provided by the meteorological station located in the pasture catchment. ET losses accounted for 35 $\%$ of the water losses in the pasture site and $47 \%$ in the forest site. On the basis of these data, replacing forests with pastures and grasslands produces an increase in annual water yield. However, Roa-Garcia et al. 2010, notes that rather than this effect as the main driver for the increase in annual flows after forest clearing, in the tropics it appears to be the reduced infiltration capacity of the soil.

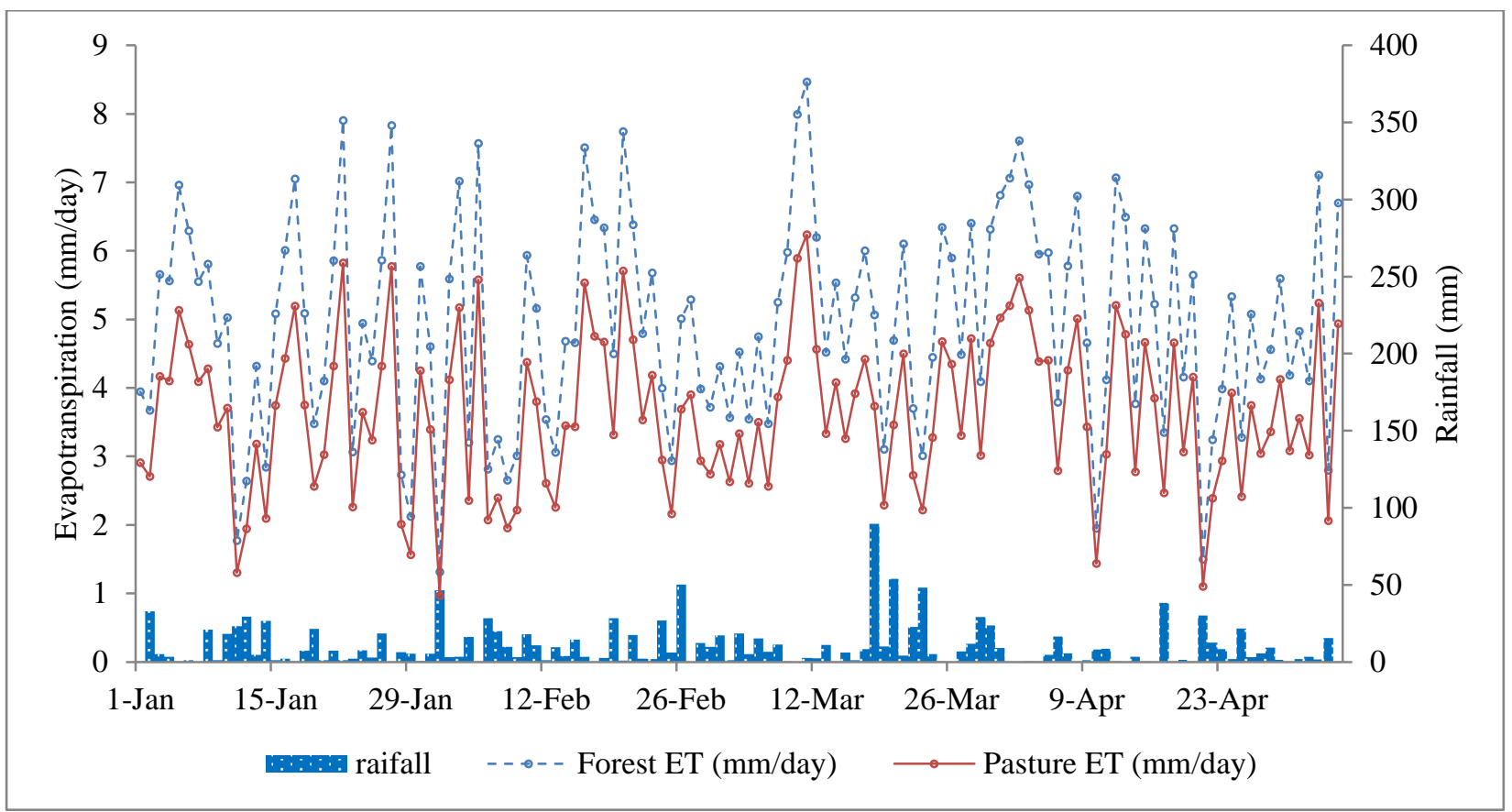

Figure 4.10 Daily Evapotranspiration and areal average rainfall for the study catchments. 


\subsection{Summary and conclusions}

The rainfall runoff characteristics of two small headwater catchments in southern Amazonia were investigated. Land cover and catchment physiographic parameters play a significant role in the hydrologic responses of the catchments. Data from this study highlight linkages between land cover and the rainfall runoff characteristics as shown in the discharge hydrographs. Analyses of individual events have shown relative differences between forest and pasture sites in terms of the rainfall-runoff responses. The pasture catchment exhibits high instantaneous peak discharges compared to the forest catchment. The pasture catchment exhibited relatively rapid response to precipitation compared to the forest catchment. Normalized discharge was also higher in the pasture catchment which also exhibited higher runoff ratios compared to the forest catchment. Initial findings confirm that hydrological responses in these catchments are driven by various factors and depend not only on the watershed features but also on prior conditions and the characteristics of the rainfall episodes, e.g. intensity. Both catchments are underlain by soils with well defined, A, $E$ and $B t$ Horizons. Soil moisture exhibits temporal variations following rainfall patterns and spatially showing the influence of topography. During the study period there is limited variation in moisture reservoirs in the study catchments, and both catchments also exhibited limited ranges in available water capacities. Results of this study highlight that land cover alterations and transformation of the headwater catchments from forests most likely contributes to the reduction in their water regulation capacity. While results presented here provide a useful initial assessment of catchment hydrological controls, further research is ongoing to better understand the influence of land use and soil moisture on discharge over a longer time period and also to characterize the influence on hydrochemical transport. Further work will use these data to validate hydrological models identifying the actual pathways of the water in the catchments, calculate mean transit times, and quantify associated hydro-chemical fluxes.

\section{ACKNOWLEDGEMENTS}

The authors wish to thank the Bundesministerin für Bildung und Forschung (BMBF) for supporting this research through their grant to the CARBIOCIAL project (Support 
Code: 01LL0902A) and the Deutscher Akademischer Austausch Dienst (DAAD) scholarship support for R. Nobrega. The authors also acknowledge the collaboration of field site host, Fazenda Missassi and thanks to Robert Müller and Alexander Kirst for field assistance. 
Chapter 5. Effects of conversion of native cerrado vegetation to pasture on soil hydro-physical properties, evapotranspiration and streamflow on the Amazonian Agricultural Frontier

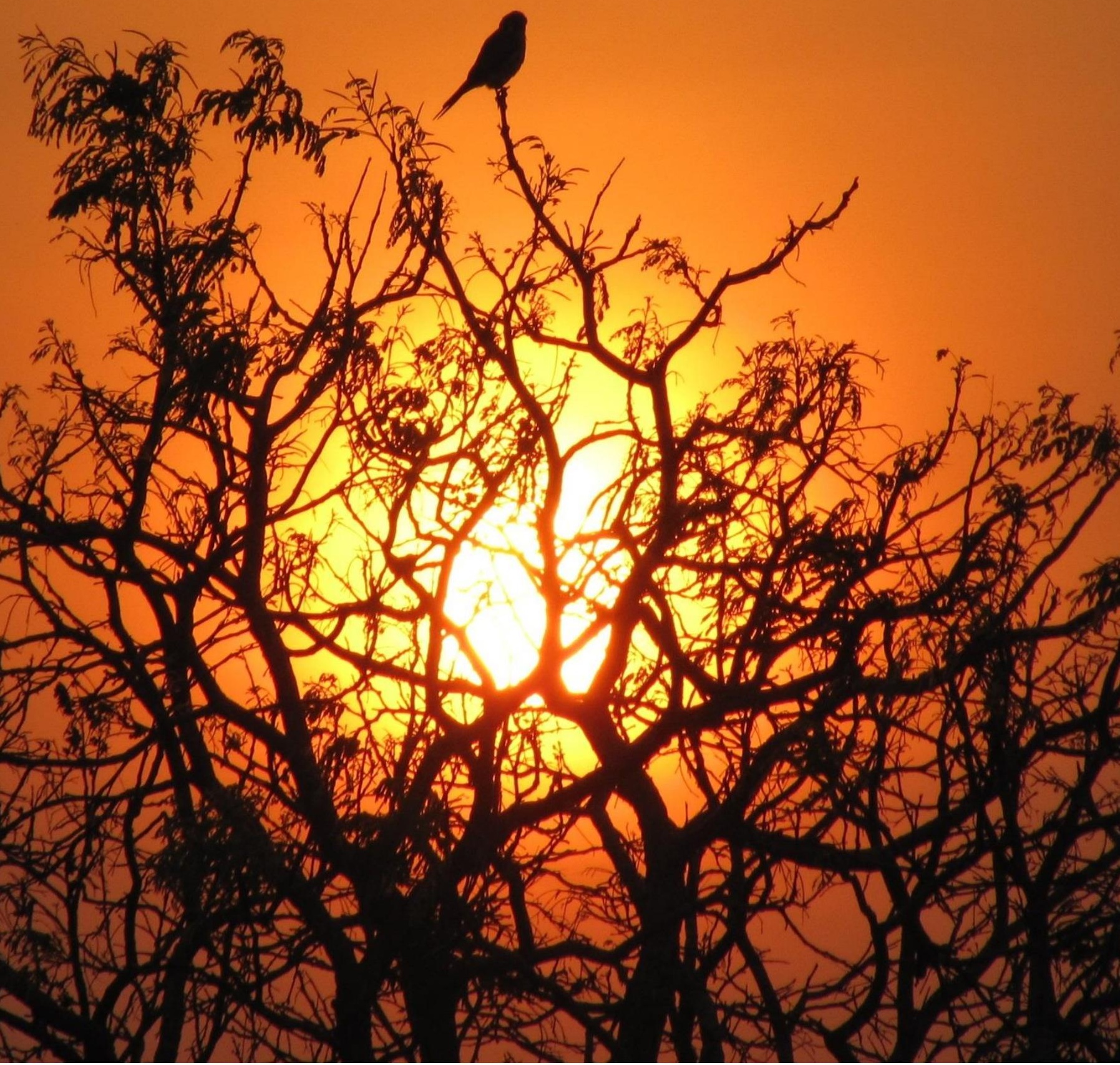




\section{Effects of conversion of native cerrado vegetation to pasture on soil hydro-physical properties, evapotranspiration and streamflow on the Amazonian Agricultural Frontier}

This manuscript is published as: Nóbrega, RLB, Guzha, AC, Torres, GN, Kovacs, K, Lamparter, G, Amorim, RSS, Couto, E, Gerold, G. 2017. Effects of conversion of native cerrado vegetation to pasture on soil hydro-physical properties, evapotranspiration and streamflow on the Amazonian agricultural frontier. PLoS One 12, e0179414. DOI:10.1371/journal.pone.0179414.

\begin{tabular}{l} 
Abstract \\
\hline Understanding the impacts of land-use change on landscape-hydrological dynamics \\
is one of the main challenges in the Northern Brazilian Cerrado biome, where the \\
Amazon agricultural frontier is located. Motivated by the gap in literature assessing \\
these impacts, we characterized the soil hydro-physical properties and quantified \\
surface water fluxes from catchments under contrasting land-use in this region. We \\
used data from field measurements in two headwater micro-catchments with similar \\
physical characteristics and different land use, i.e. cerrado sensu stricto vegetation \\
and pasture for extensive cattle ranching. We determined hydraulic and physical \\
properties of the soils, applied ground-based remote sensing techniques to estimate \\
evapotranspiration, and monitored streamflow from October 2012 to September 2014 . \\
Our results show significant differences in soil hydro-physical properties between the \\
catchments, with greater bulk density and smaller total porosity in the pasture \\
catchment. We found that evapotranspiration is smaller in the pasture (639 $31 \%$ mm \\
yr ${ }^{-1}$ ) than in the cerrado catchment (1,004 $\pm 24 \%$ mm yr $\left.{ }^{-1}\right)$, and that streamflow from \\
the pasture catchment is greater with runoff coefficients of 0.40 for the pasture and \\
0.27 for the cerrado catchment. Overall, our results confirm that conversion of cerrado \\
vegetation to pasture causes soil hydro-physical properties deterioration, reduction in \\
evapotranspiration reduction, and increased streamflow.
\end{tabular}

\subsection{Introduction}

Despite accounting for nearly half of all tropical forests and approximately $6 \%$ of the Earth's land surface, tropical dry forests are underrepresented in the literature on tropical forest research (Sánchez-Azofeifa et al., 2005; Santos et al., 2011; Farrick and Branfireun, 2013). Further, tropical dry forests are recognized as one of the world's most endangered terrestrial ecosystems, as they are threatened by deforestation and climate change impacts (Miles et al., 2006).

Available empirical data for tropical forests are insufficient for adequate parameterization of water balance models, including the understanding of the effects of deforestation on evapotranspiration and runoff ratios. Therefore, increased efforts with focus on field-based characterizations and catchment processes are 
recommended to quantify human influence on all aspects of tropical hydrology (Wohl et al., 2012). Farrick and Branfireun (Farrick and Branfireun, 2013) supported this recommendation, adding that standard hydrological metrics such as runoff coefficients also lack comprehensive characterization in tropical dry forests.

The Cerrado ecosystem, commonly called the Brazilian savanna, is South America's largest tropical dry forest and second-most extensive biome. Although public interest in deforestation in Brazil focuses on the Amazon biome, most of the deforestation has occurred in areas adjacent to the Cerrado-Amazon transition zone (Smith et al., 1998), also known as the Amazonian agricultural frontier. Approximately $50 \%$ of the original 2 million $\mathrm{km}^{2}$ of the Cerrado area is under agricultural use (Klink and Machado, 2005; Sano et al., 2008; Beuchle et al., 2015), compromising ca. $80 \%$ of the primary cerrado vegetation (Myers et al., 2000). Other studies indicate that the conversion of cerrado vegetation will continue to be a dominant process of land-use change in Brazil (Lapola et al., 2011, 2013).

It is widely known that the removal of forest cover associated with agricultural expansion shifts water balances by reducing evapotranspiration and increasing streamflow (Brown et al., 2005; Recha et al., 2012; Neill et al., 2013). Studies evaluating the impacts of land-use change on hydrological processes in the Amazon are relatively common (Williams and Melack, 1997; Neill et al., 2001; Ballester, 2003; Germer et al., 2009; Figueiredo et al., 2010b; Richey et al., 2011). However, assessments of the environmental impacts of the Cerrado conversion into agropastoral landscapes are scarce (Jepson et al., 2010; Hunke et al., 2015b; Oliveira et al., 2015) despite the importance of the cerrado in provisioning and maintaining ecosystem services such as adequate water quantity and quality (Alho, 2012; Davidson et al., 2012; Hunke et al., 2015a). Although studies show that land-cover change in the Brazilian Cerrado alters the water balance, e.g. by increasing streamflow (Costa et al., 2003; Guzha et al., 2013a), they do not allow generalizations since they are based mostly on low-resolution datasets. In this biome, water balance components such as streamflow and infiltration, and soil physical properties are poorly understood, especially at field scale in the Cerrado (Juhász et al., 2007; Oliveira et al., 2015). Furthermore, the scarcity of hydrometeorological data, and the lack of information on 
vegetation and geological characteristics are major limitations for a reliable quantification of these land-use change effects.

In fact, most of hydrological characterizations of the Cerrado are often limited to either grey or non-peer reviewed literature, which is difficult to access. Evapotranspiration has been the water balance component studied in greater detail in this biome (da Rocha et al., 2009; Giambelluca et al., 2009). In more recent studies, the emphasis has been on the use of remote sensing techniques to establish a better understanding of evapotranspiration in large areas of the Brazilian Cerrado (Lathuillière et al., 2012; Scherer-Warren, 2012; Scherer-Warren and Rodrigues, 2013; Andrade et al., 2014; Oliveira et al., 2014; Ataíde and Baptista, 2015). However, there are limitations to obtain cloud-free satellite images in this region of Brazil (Sano et al., 2007), and due to inconsistent field information, studies often have restrictions to apply ground-based validation methods (da Silva et al., 2015).

Burt and McDonnell (Burt and McDonnell, 2015) emphasize that there is a noticeable need for field research to seek new fundamental understanding of catchment hydrology particularly in regions outside of the traditional focus, such as the Cerrado. Due to the lack of data with high temporal and spatial resolution for this region of Brazil, macroscale analyses are often the only alternative. Our study focuses on small headwater catchments because they are the origins of larger rivers, and, as outlined by Guzha et al. (Guzha et al., 2015), hydrological signatures exhibited in these catchments can provide useful indicators of environmental changes in larger areas. Studies using small watersheds in the Brazilian Cerrado are usually more feasible than macro-scale approaches to detected hydrological responses to human impacts regarding land-use and land-cover changes (Jepson, 2005; Oliveira et al., 2014).

Our hypothesis is that conversion of undisturbed cerrado to pasture leads to soil hydrophysical degradation, increased stream discharge, and reduced evapotranspiration fluxes. In this respect, our study aims to aid filling the gap in the understanding of soil degradation and hydrological processes in active deforestation zones on the Amazonian agricultural frontier in Brazil. The specific objectives were to: i) determine soil hydro-physical properties, and; ii) quantify streamflow and evapotranspiration; 
from two adjacent catchments whose major difference is the land use (undisturbed cerrado vs. pasture).

\subsection{Methods}

\subsubsection{Study area description}

We conducted this study in the municipality of Campo Verde (Mato Grosso state, Brazil), situated in the das Mortes River basin and in the Cerrado biome (Fig 5.1). This area is underlain by a Cretaceous sandstone (Schneider, 1963). The soils in this biome are generally highly weathered and acidic with high aluminum concentrations, thus requiring fertilizers and lime for crop production and livestock farming (Ratter et al., 1997). The climate in this region is tropical wet and dry, and the mean annual precipitation is $1,800 \mathrm{~mm} \mathrm{yr}^{-1}$; the wet season extends from October to April, and the dry season extends from May to September (Marcuzzo et al., 2011).

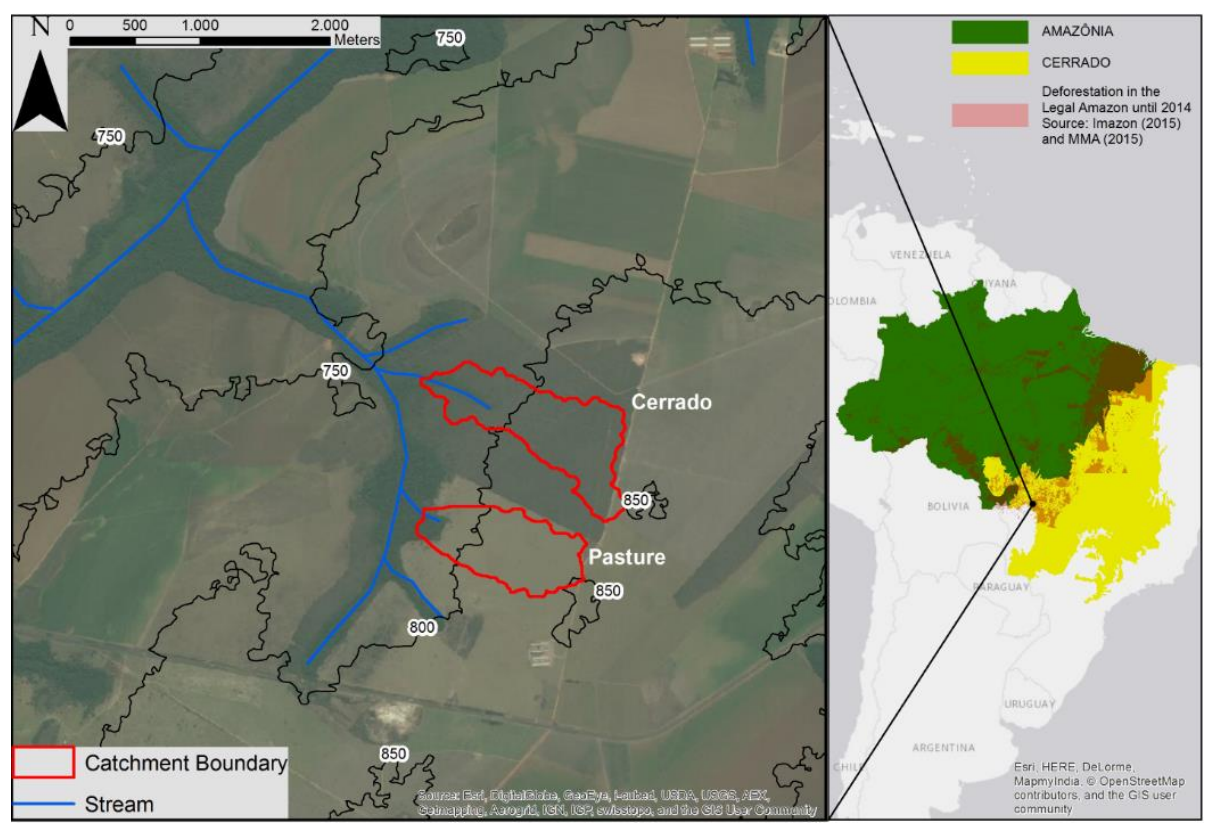

Figure 5.1 Overview of the Amazon and Cerrado biomes, the deforestation extension in the Legal Amazon, and the location of the cerrado and pasture catchments. Deforestation data from: IMAZON [Internet]; 2016. Available from:

http://www.imazongeo.org.br/doc/downloads.php; and MMA [Internet]; 2016. Available from: http://mapas.mma.gov.br/i3geo/datadownload.htm.

We compared two adjacent headwater micro-catchments selected on the basis of their Predominant Land Use (PLU), i.e. cerrado vegetation and pasture for extensive cattle ranching, and monitored them from October 2012 to September 2014. The selected catchments are less than $1 \mathrm{~km}^{2}$ in spatial extent, with similar slopes, aspects, soils, 
and climate. We used the space for time substitution approach for the comparison between the catchments, which it is often used in hydrology to compare adjacent small catchments with similar characteristics and different land cover (de Moraes et al., 2006; Germer et al., 2010; Roa-García et al., 2011; Muñoz-Villers and McDonnell, 2013; Ogden et al., 2013). This method has yielded significant insights in the hydrologic response of landscapes in the absence of historical data and one major different pattern (Troch et al., 2015).

With an area of 78 ha, the cerrado catchment is located within the boundaries of the Rancho do Sol farm $\left(15.797^{\circ} \mathrm{S}, 55.332^{\circ} \mathrm{W}\right)$ and is mostly covered by cerrado sensu stricto vegetation. The cerrado sensu stricto is described as a deep-rooting and dense orchard-like vegetation consisting of many species of grasses and sedges mixed with a great diversity of forbs, such as Leguminosae, Compositae, Myrtaceae, and Rubiaceae plant species, and trees with an average height of $6 \mathrm{~m}$ (Goodland, 1971; Goodland and Pollard, 1973; Canadell et al., 1996; Ratter et al., 1997; Furley, 1999). The adjacent pasture catchment (58 ha) is located on the Gianetta farm (15.805 $\mathrm{S}$, $55.336^{\circ} \mathrm{W}$ ). In 1993 the original cerrado vegetation in this catchment was removed and replaced by Brachiaria grass species for intensive cattle farming. The soils in both micro-catchments are Arenosols (IUSS Working Group WRB, (IUSS Working Group WRB, 2015)) characterized by a sandy loam texture, and are correlated with Entisols Quartzipsamments (Soil Survey Staff, 2015) and Neossolos Quartzenicos (Brazilian Soil Classification, (EMBRAPA, 2006)).

Although each catchment was selected on the basis of the PLU, gallery forests exist in both micro-catchments following the stream channel. The width of the gallery forest within each catchment varies from 50 to $200 \mathrm{~m}$. The gallery forests have a higher plant diversity compared to the dominant cerrado vegetation (Felfili and Silva Júnior, 1992; Marimon et al., 2010), and they are common formations in the riparian zones in the Cerrado, which occupy about $5 \%$ of the Cerrado biome area (Felfili et al., 2001).

\subsection{Catchment instrumentation, characterization, and analysis}

\subsubsection{Topographic survey}

To define the catchment boundaries and topographic features for the pasture catchment, we used the Quarryman ${ }^{\circledR}$ Auto-Scanning Laser System (ALS) LaserAce 
Scanner 300p laser profiling system (Measurement Devices Ltd., UK). Due to interferences of the cerrado vegetation in the laser scanner results, we surveyed the cerrado catchment by using a ProMark ${ }^{\mathrm{TM}}$ differential Global Positioning System (dGPS) instrument (Ashtech, USA). For the survey of the gallery forests, we used the dGPS instrument and a Geodetic Rover System (GRS1) GPS (Topcon, USA) with an integrated TruPulse ${ }^{\circledR} 360^{\circ}$ B distance measurement system (Laser Technology Inc., USA). We used the topographic data to develop a Digital Elevation Model (DEM) at 5 $\mathrm{m}$ resolution for each catchment. Catchment slope distributions and Compound Topographic Index (CTI) were derived from the DEMs. The CTI is a hydrologicallybased compound topographic attribute, represented by a steady state wetness index as a function of both the slope and the upstream contributing area (Moore et al., 1991). High CTI is represented by areas with greater contributing areas and low slopes. The CTI was computed using the algorithm described by Gessler et al. (Gessler et al., 1995), which was implemented in ArcGIS $^{\circledR}$ by Evans et al. (Evans, 2014).

\subsubsection{Soil geostatistical analysis and sampling}

We delineated transects for soil sampling based on the surface elevation and geostatistical analysis of the clay content to regionalize the soil properties (Voltz and Goulard, 1994; Chaplot et al., 2000; Montanari et al., 2012). For the surface elevation analysis we used the DEMs derived from the topographic survey, and for the clay content we collected and analyzed 45 disturbed soil samples at the depth intervals of 0-20 and 40-60 cm from randomly selected points throughout each catchment. We interpolated the clay content results at each soil depth using isotropic variogram analyses and the ordinary kriging method. The variogram results of soil properties as a prerequisite to kriging allow the quantification of the semivariance for any given distance (Herbst and Diekkrüger, 2002).

For the transect delineation only the interpolation of the clay content at $0-20 \mathrm{~cm}$ soil depth was used because it showed variogram correlations of 0.94 for the cerrado catchment and 0.83 for the pasture catchment, which were higher than the correlations obtained with the $40-60 \mathrm{~cm}$ soil depth. We validated the interpolation results by using the leave-one-out cross-validation method (Herbst et al., 2006), which was based on leaving actual data out one at time and estimating the properties of the location from 
the neighboring data. We then categorized the surface elevation in 5 equal intervals and clay content in quintiles, and delineated transects from the catchments crest to the stream valley passing over all elevation and clay content categories. We established 15 approximately equally-spaced points along the transects in each catchment to collect in each point one disturbed sample and two undisturbed soil core samples $(4.8 \mathrm{~cm}$ in diameter and $5.2 \mathrm{~cm}$ in height) at depth intervals of $0-10,10-20$, $20-40$, and $40-60 \mathrm{~cm}$.

\subsubsection{Soil physical and hydraulic properties}

The disturbed soil samples were analyzed to obtain the particle size distribution, and the undisturbed samples were used to determine bulk density, saturated hydraulic conductivity ( $\mathrm{K}_{\text {sat }}$ ), particle size distribution, total porosity, macroporosity, microporosity, and field capacity. Particle size distributions of the soils were obtained by using the pipette method (Gee, 1986) after chemical dispersion and removal of organic matter and carbonates. Soil bulk density was estimated by weighing the samples after drying them in an oven at $105{ }^{\circ} \mathrm{C}$ (Burke et al., 1986). $\mathrm{K}_{\text {sat }}$ was determined by using the constant-head permeameter method. Total porosity was quantified with the cylinder volume method (EMBRAPA, 1997); the macroporosity (pore diameter $\geq 0.05 \mathrm{~mm}$ ) was determined using the tension table method (EMBRAPA, 1997); and the microporosity was obtained by the difference between the total porosity and the macroporosity. Field capacity moisture content was estimated with the pressure membrane method at $-0.01 \mathrm{MPa}$ (Richards, 1947).

\subsubsection{Rainfall and evapotranspiration}

To account for rainfall spatial variability, three tipping bucket rain gauges $(0.2 \mathrm{~mm}$

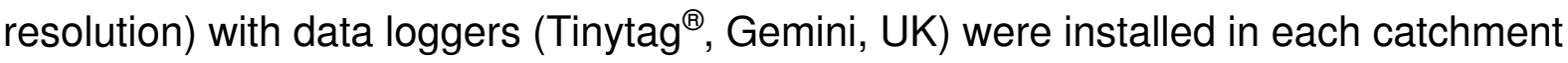
to record rainfall at 10-min intervals. A WS-GP1 weather station (Delta-T, UK) installed at a farm approximately $7 \mathrm{~km}$ from the two catchments $\left(15.741435^{\circ} \mathrm{S}, 55.363134^{\circ}\right.$ W) provided total solar radiation, net solar radiation, temperature, relative humidity, wind speed and direction, and rainfall data at 10-min intervals. Using this weather data we quantified the reference evapotranspiration ( $\mathrm{E}_{\mathrm{To}}$ ) using the standardized reference evapotranspiration equation (ASCE-EWRI, 2005): 
$E_{T o}=\frac{0.408 \Delta\left(\mathrm{R}_{\mathrm{n}}-\mathrm{G}\right)+\gamma \frac{C_{n}}{\mathrm{~T}+273} \mathrm{u}_{2}\left(\mathrm{e}_{\mathrm{s}}-\mathrm{e}_{\mathrm{a}}\right)}{\Delta+\gamma\left(1+C_{d} \mathrm{u}_{2}\right)}$

where $\mathrm{E}_{\mathrm{To}}$ is in $\mathrm{mm}$ day $^{-1}$ or $\mathrm{mm} \mathrm{h}^{-1}$ for daily or hourly time steps), $\mathrm{Rn}_{\mathrm{n}}$ is the surface net

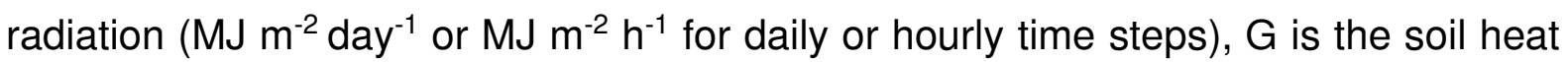
flux density ( $M J \mathrm{~m}^{-2}$ day $^{-1}$ or $\mathrm{MJ} \mathrm{m}^{-2} \mathrm{~h}^{-1}$ for daily or hourly time steps), $\mathrm{T}$ is the mean daily air temperature $\left({ }^{\circ} \mathrm{C}\right)$ and $\mathrm{u}_{2}$ is the wind speed $\left(\mathrm{m} \mathrm{s}^{-1}\right)$ at $2 \mathrm{~m}$ height, $\mathrm{e}_{\mathrm{s}}$ and $\mathrm{e}_{\mathrm{a}}$ are, respectively, the saturation and actual vapor pressure $(\mathrm{kPa}), \mathrm{e}_{\mathrm{s}}-\mathrm{e}_{\mathrm{a}}$ is the saturation vapor pressure deficit $(\mathrm{kPa}), \Delta$ is the slope of vapor pressure curve $(\mathrm{kPa}$ $\left.{ }^{\circ} \mathrm{C}^{-1}\right), \mathrm{Y}$ is the psychrometric constant $\left(\mathrm{kPa}{ }^{\circ} \mathrm{C}^{-1}\right), \mathrm{C}_{\mathrm{n}}$ and $\mathrm{C}_{\mathrm{d}}$ are, respectively, the numerator and denominator constants for the reference type and calculation time step given by ASCE-EWRI (ASCE-EWRI, 2005).

We applied satellite-based image-processing models to improve our $\mathrm{E}_{\mathrm{T}}$ estimation for the study area. We estimated the evapotranspiration $\left(\mathrm{E}_{\mathrm{T}}\right)$ by using a combination of the Surface Energy Balance Algorithm for Land (SEBAL) and Mapping EvapoTranspiration at high Resolution with Internalized Calibration (METRICTM) models, as described by Allen et al. (Allen et al., 2011). Both models are based on the energy balance at the land surface. SEBAL is based on latent heat flux as a residual of the energy balance equation, and its principles and computational basis are described in Bastiaanssen et al. (Bastiaanssen et al., 1998) and Bastiaanssen (Bastiaanssen, 2000). METRIC considers soil and vegetation as a sole source in the estimation of $\mathrm{E}_{\mathrm{T}}$, and its principles and application procedures are described in Allen et al. (Allen et al., 2007). The application of SEBAL has shown to be adequate to quantify the energy balance for the $\mathrm{E}_{\mathrm{T}}$ estimation for Cerrado landscapes (Ruhoff et al., 2012; da Silva et al., 2015), and the use of the METRIC model allows to directly integrate a variety of factors, such as orchard architecture, land-use practices, water stress occurrence, and changes in the weather conditions during the day (Paço et al., 2014; Mkhwanazi et al., 2015).

SEBAL was applied by using a composite of spectral bands 1-7 (path 226 and row 071) of all 13 valid satellite scenes from the Landsat 7 Enhanced Thematic Mapper Plus $(\mathrm{ETM}+)$ for our study area and period to determine the energy consumed by the Ет process; this is calculated as a residual of the surface energy equation (Eq (2)) using the software ERDAS Imagine ${ }^{\circledR}$ v. 14 (Hexagon AB, USA). To match the satellite 
spatial extension we used a 90-m-resolution DEM (Shuttle Radar Topography Mission, version 4.1, (Jarvis et al., 2008)) cropped to the study area to adjust the surface temperature according to the differences in elevation and to derive surface slope and aspect information as required in SEBAL to estimate solar radiation (Allen et al., 2007). The Earth-Sun distance parameter, also required by SEBAL, was obtained from Chander et al. (Chander et al., 2009) when not available in the satellite metadata file. $L E=R_{n}-G-H$,

where $L E$ is the latent heat flux, $R_{n}$ is the instantaneous net radiation, $G$ is the soil heat flux, and $\mathrm{H}$ is the sensible heat flux (all in $\mathrm{W} \mathrm{m}^{-2}$ ).

METRIC was used to compute the instantaneous $E_{T}$ from the obtained latent heat flux from SEBAL for each pixel within the catchments at the instant of satellite overpass (Eq (3)). We used two anchor points to define the limit conditions by means of a cold pixel $\left(15.7402^{\circ} \mathrm{S}, 55.5292^{\circ} \mathrm{W}\right)$ and a hot pixel $\left(15.7264^{\circ} \mathrm{S}, 55.3325^{\circ} \mathrm{W}\right)$ for the energy balance over the study area for the internal calibration of sensible heat flux of METRIC (Allen et al., 2007).

$E_{\text {Tinst }}=3600 \frac{L E}{\lambda \rho_{w}}$,

where $E_{T i n s t}$ is the instantaneous $E_{T}\left(\mathrm{~mm} \mathrm{~h}^{-1}\right), 3600$ is the time conversion from seconds to hours, $\rho_{\mathrm{w}}$ is the density of water $\left(\sim 1000 \mathrm{~kg} \mathrm{~m}^{-3}\right)$, and $\lambda$ is the latent heat of vaporization $\left(\mathrm{J} \mathrm{kg}^{-1}\right)$ representing the heat absorbed when one $\mathrm{kg}$ of water evaporates and it is computed as:

$\lambda=\left[2.501-0.00236\left(T_{s}-273.15\right)\right] \times 10^{6}$,

where $T_{s}$ is the surface temperature $(K)$.

We applied the evaporative fraction ( $\left.E_{T r F}\right)$ and daily $E_{T o}$ to estimate the actual daily $E_{T}$ assuming that the $\mathrm{E}_{\mathrm{TrF}}$ is constant during a day (Allen et al., 2007) according to $\mathrm{Eq}$ (5). Additionally, the Penman-Monteith equation, which we used to estimate $\mathrm{E}_{\mathrm{To}}$, is known to well-represent the impacts of advection (Allen et al., 2011). The $\mathrm{E}_{\mathrm{T}}$ values for each type of land use were area-weighted and summed to obtain the total actual evapotranspiration estimation for each catchment.

$E_{T}=E_{T r F} E_{T o}$. 
Table 5.1 Satellite scenes description, weather data at the satellite overpass time, and ETrF values.

\begin{tabular}{|c|c|c|c|c|c|c|c|c|c|c|c|}
\hline \multicolumn{4}{|c|}{ Landsat 7 ETM+ scene description } & \multicolumn{4}{|c|}{ Weather station } & \multicolumn{4}{|c|}{ ETrF } \\
\hline \multirow[t]{2}{*}{ Date } & \multirow{2}{*}{$\begin{array}{l}\text { Satellite } \\
\text { overpas } \\
\text { s time } \\
\text { (GMT) }\end{array}$} & \multirow{2}{*}{$\begin{array}{l}\text { Relative } \\
\text { Earth-Sun } \\
\text { distance }^{a}\end{array}$} & \multirow{2}{*}{$\begin{array}{l}\text { Solar } \\
\text { zenith } \\
\text { angle } \\
\text { cosin } \\
\mathrm{e}^{\mathrm{b}}\end{array}$} & \multirow{2}{*}{$\begin{array}{l}\text { Air } \\
\text { temperatur } \\
\mathrm{e}\left({ }^{\circ} \mathrm{C}\right)\end{array}$} & \multirow{2}{*}{$\begin{array}{l}\text { Relative } \\
\text { humidit } \\
\text { y (\%) }\end{array}$} & \multirow{2}{*}{$\begin{array}{l}\text { Wind } \\
\text { speed } \\
\left(\mathrm{m} \mathrm{s}^{-1}\right)\end{array}$} & \multirow{2}{*}{$\begin{array}{l}\text { Surface } \\
\text { net } \\
\text { radiation } \\
\left(\mathrm{MJ} \mathrm{m}^{-2} \mathrm{~h}^{-}\right. \\
\left.{ }^{1}\right)\end{array}$} & \multicolumn{2}{|c|}{ Cerrado } & \multicolumn{2}{|c|}{ Pasture } \\
\hline & & & & & & & & GF & PLU & GF & PLU \\
\hline 09 Oct 12 & $13: 41$ & 0.99861 & 0.882 & 29.5 & $49 \%$ & 3.2 & 612 & 1.09 & 0.93 & 1.25 & 0.72 \\
\hline 02 Mar 13 & 13:41 & 0.99108 & 0.832 & 26.2 & $75 \%$ & 4.6 & 532 & 1.21 & 0.92 & 1.07 & 0.64 \\
\hline $08 \mathrm{Jul} 13$ & $13: 41$ & 1.01668 & 0.652 & 29.0 & $34 \%$ & 2.8 & 648 & 0.63 & 0.52 & 0.66 & 0.16 \\
\hline 10 Sep 13 & 13:41 & 1.00698 & 0.811 & 30.9 & $30 \%$ & 5.3 & 558 & 0.61 & 0.37 & 0.70 & 0.19 \\
\hline 26 Sep 13 & $13: 41$ & 1.00250 & 0.855 & 27.7 & $28 \%$ & 1.9 & 601 & 0.84 & 0.52 & 0.77 & 0.15 \\
\hline 13 Nov 13 & $13: 41$ & 0.98961 & 0.905 & 27.0 & $66 \%$ & 3.4 & 672 & 1.10 & 0.76 & 1.17 & $N / A^{c}$ \\
\hline 29 Nov 13 & $13: 41$ & 0.98641 & 0.896 & 27.9 & $68 \%$ & 2.1 & 667 & $\mathrm{~N} / \mathrm{A}^{\mathrm{c}}$ & 1.29 & $\mathrm{~N} / \mathrm{A}^{\mathrm{c}}$ & 0.97 \\
\hline 01 Feb 14 & $13: 42$ & 0.98536 & 0.847 & 27.0 & $69 \%$ & 2.9 & 495 & $\mathrm{~N} / \mathrm{A}^{\mathrm{c}}$ & 1.19 & $N / A^{c}$ & 0.51 \\
\hline 06 Apr 14 & $13: 42$ & 1.00069 & 0.791 & 27.4 & $73 \%$ & 2.1 & 630 & 1.14 & 0.96 & 0.94 & 0.60 \\
\hline 25 Jun 14 & $13: 43$ & 1.01647 & 0.651 & 24.5 & $67 \%$ & 2.1 & 430 & 1.20 & 0.98 & 0.96 & 0.47 \\
\hline 11 Jul 14 & $13: 43$ & 1.01661 & 0.659 & 20.9 & $80 \%$ & 3.4 & 453 & 1.20 & 0.96 & 1.10 & 0.45 \\
\hline 12 Aug 14 & $13: 43$ & 1.01332 & 0.725 & 27.3 & $46 \%$ & 2.0 & 510 & 0.91 & 0.68 & 0.77 & 0.30 \\
\hline 13 Set 14 & $13: 43$ & 1.00620 & 0.823 & 30.2 & $38 \%$ & 1.8 & 458 & 1.16 & 0.89 & 1.03 & 0.61 \\
\hline
\end{tabular}

The $\mathrm{E}_{\mathrm{TrF}}$ is calculated as the ratio of the $\mathrm{E}_{\text {Tinst }}$ derived for each pixel to the $\mathrm{E}_{\mathrm{To}}$ at an hourly time step computed from weather data at the time of the satellite overpass (Allen et al., 1998, 2011) using Eq (6). To quantify the Eт we used the mean and the respective \pm 1 standard deviation of the obtained values for $E_{T r F}$ for the wet and dry seasons, separately, considering all valid pixels within each catchment domain. Table 5.1 shows the description of the satellite scenes, the main local weather data at the satellite overpass time, and the respective $E_{T r F}$ values for the study areas. Some results were not available due to cloud masking or Scan Line Corrector-Off malfunction [86].

$E_{T r F}=\frac{E T_{i n s t}}{E_{T o}}$.

5.3.5. Catchment discharge and hydrograph analysis

At the outlet of each catchment, an adjustable weir was installed. During the wet season the weirs were maintained as rectangular weirs, and during the dry season a $\mathrm{v}$-notch contraction was inserted. At a distance of $2 \mathrm{~m}$ upstream of each weir, a DS 5X (OTT, USA) multiparameter probe was installed to measure, among other variables, 
the water level at 10-min intervals. For the rectangular weir, we used the standard flow equation (Eq (7)) based on the Bernoulli equation to quantify stream discharge. For the v-notch weir, the Kindsvater-Shen equation (Eq (8)) and respective calibration adjustment functions (Eqs (9) and (10)) were used to quantify discharge:

$Q=\frac{2}{3} C_{d r} b \sqrt{2 g} h^{\frac{3}{2}}$,

$Q=\frac{8}{15} C_{e} \sqrt{2 g} \tan \left(\frac{\theta}{2}\right) h_{e^{\frac{5}{2}}}$,

$K_{h}=0.001[\theta(1.395 \theta-4.296)+4.135]$,

$C_{e}=\theta(0.02286 \theta-0.05734)+0.6115$,

where $Q$ is the discharge over the weir $\left(\mathrm{m}^{3} \mathrm{~s}^{-1}\right)$, $C_{d r}$ and $C_{e}$ are the effective dimensionless discharge coefficients for the rectangular and v-notch weirs, respectively, $b$ is the weir length $(m), \theta$ is the v-notch's angle (radians), $h$ is the upstream head above the weir's crest $(m)$, he is the effective head $\left(h+K_{h}\right)$, and $K_{h}$ is the head-adjustment factor.

In each catchment, we conducted discharge calibration measurements with an acoustic digital current meter (ADC, OTT, USA) to estimate the $\mathrm{C}_{\mathrm{dr}}$ factor for each catchment. The obtained $\mathrm{Cdr}_{\mathrm{dr}}$ values were 0.74 for the cerrado catchment and 0.65 for the pasture catchment. The discharged data were normalized by the correspondent catchment area to allow comparisons between the catchments. To estimate the total streamflow, we used the mean discharge values for each wet and dry seasons. Additionally, we applied \pm 1 standard deviation of the mean of each wet and dry seasons to the discharge-gap days in order to estimate the total error.

The discharge time series were analyzed with the recursive digital filter method (Eckhardt, 2005) implemented in the Web GIS-based Hydrograph Analysis Tool (WHAT) for baseflow separation (Lim et al., 2005, 2010). The baseflow index (BFI) was computed as the ratio of baseflow to total discharge. The runoff coefficient (Rc) was determined as the ratio of total discharge to total rainfall. Flow-duration curves (FDCs) were derived from the daily discharge data in order to compare the differences in high, low, and median flows between the catchments (Vogel and Fennessey, 1994), and catchment flashiness indices were obtained using the method described by Baker et al. (Baker et al., 2004). 


\subsubsection{Statistical analyses}

Pearson's correlation analysis was applied to test the relationships between the soil properties, and between the rainfall daily values in each catchment. The results were compared using two sample t-test for the data with normal distribution (soil properties), and a nonparametric test (Mann-Whitney $U$ ) in the other cases (rainfall, $E_{T}$, and streamflow), to determine whether the results were significantly different. The significance threshold was set at .05 .

\subsection{Results}

\subsubsection{Catchment physiographic attributes}

The soil sampling points, the slope distribution, and the CTI for each catchment are shown in Fig 5.2. The cerrado and pasture catchments have similar slope ranges with most of the values between 0 and $10^{\circ}$ and an average of approximately $8^{\circ}$. In both catchments over $95 \%$ of the area shows CTI values ranging between 5 and 12, and areas with CTI over 10 have linear form extending from the crest to the outlet of the catchments, which indicates the surface flow pathways.

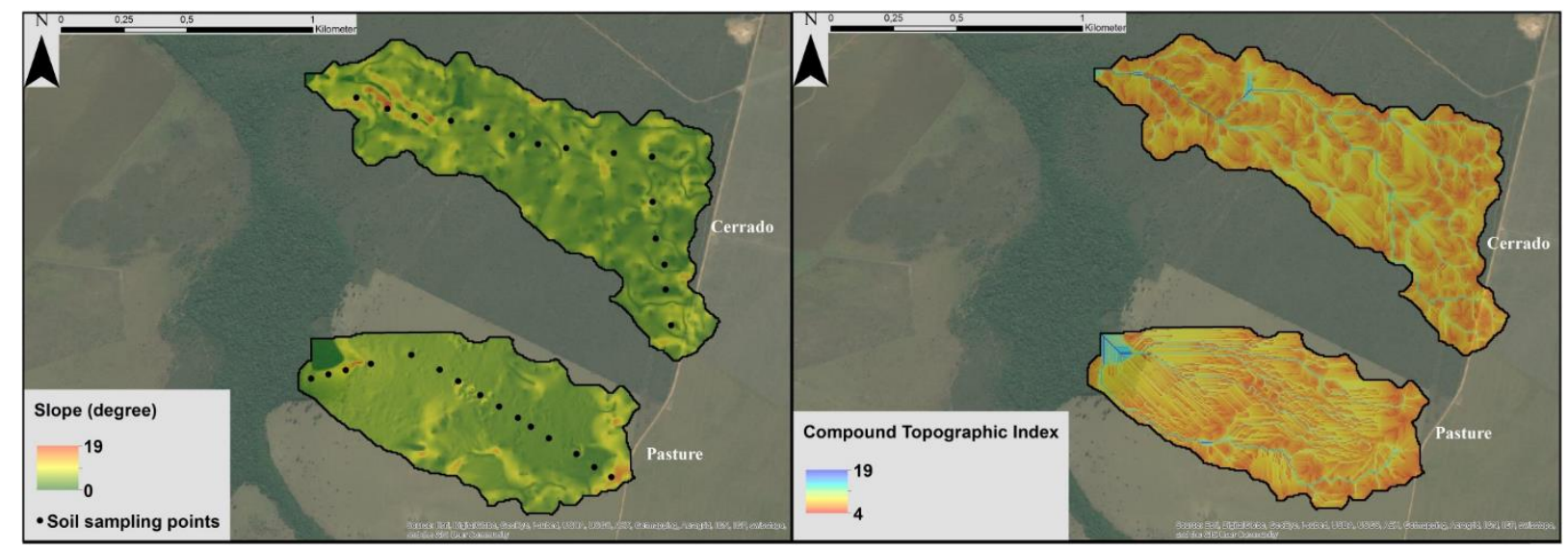

Figure 5.2 Slope, soil sampling points, and Compound Topographic Index (CTI) in the cerrado and pasture catchments.

Table 5.2 shows a summary of the topographic characteristics of the catchments. The data are distinguished for the gallery forest and the PLU areas. The topographic survey shows that the gallery forests cover approximately $7 \%$ of the total areas in both catchments. 
Table 5.2 Summary of catchments' physical and topographic characteristics.

\begin{tabular}{|c|c|c|c|c|c|c|}
\hline & \multicolumn{3}{|c|}{ Cerrado catchment } & \multicolumn{3}{|c|}{ Pasture catchment } \\
\hline & $\begin{array}{l}\text { Gallery } \\
\text { Forest }\end{array}$ & $\begin{array}{l}\text { PLU } \\
\text { Area }\end{array}$ & $\begin{array}{l}\text { Total } \\
\text { Area }\end{array}$ & $\begin{array}{l}\text { Gallery } \\
\text { Forest }\end{array}$ & $\begin{array}{l}\text { PLU } \\
\text { Area }\end{array}$ & $\begin{array}{l}\text { Total } \\
\text { Area }\end{array}$ \\
\hline Area $\left(\mathrm{km}^{2}\right)$ & 0.05 & 0.73 & 0.78 & 0.04 & 0.54 & 0.58 \\
\hline (\% of total) & $(6.4 \%)$ & $(93.6 \%)$ & $(100 \%)$ & $(6.9 \%)$ & $(93.1 \%)$ & $(100 \%)$ \\
\hline $\begin{array}{l}\text { Predominant } \\
\text { land cover }\end{array}$ & \multicolumn{3}{|c|}{$\begin{array}{c}\text { Cerrado sensu stricto } \\
\text { vegetation }\end{array}$} & \multicolumn{3}{|c|}{$\begin{array}{c}\text { Grassland (Brachiaria } \\
\text { species) }\end{array}$} \\
\hline Soil type & \multicolumn{3}{|c|}{ Arenosols } & \multicolumn{3}{|c|}{ Arenosols } \\
\hline Soil texture & \multicolumn{3}{|c|}{ Sandy loam } & \multicolumn{3}{|c|}{ Sandy loam } \\
\hline Aspect & \multicolumn{3}{|c|}{ E-W } & \multicolumn{3}{|c|}{ E-W } \\
\hline $\begin{array}{c}\text { Average } \\
\text { Elevation }(\mathrm{m})\end{array}$ & 770 & 814 & 811 & 775 & 821 & 818 \\
\hline $\begin{array}{l}\text { Average } \\
\text { slope }\left({ }^{\circ}\right)\end{array}$ & 7.6 & 4.6 & 4.8 & 3.9 & 4.4 & 4.4 \\
\hline
\end{tabular}

\subsubsection{Soil physical and hydraulic properties}

Table 5.3 shows that the cerrado and pasture catchments have comparable soil properties. The pasture catchment shows a greater bulk density $(p<.0001)$ at $0-40$ $\mathrm{cm}$ depth and a lower total porosity $(p<.001)$ at $0-10 \mathrm{~cm}$ soil depth compared to the cerrado catchment. Our findings confirm results from Valpassos et al. (Valpassos et al., 2001), who reported greater bulk densities in the topsoil of a pasture compared to an area covered by cerrado vegetation. The gallery forest and the PLU areas of the cerrado catchment do not show significant differences in total porosity and bulk densities with identical bulk density results at $0-10 \mathrm{~cm}$ soil depth $\left(1.43 \pm 9 \% \mathrm{~g} \mathrm{~cm}^{-3}\right)$, whereas these properties found in the gallery forest area of the pasture catchment are significantly smaller than those in its PLU area $(p<.0001)$, especially at $0-20 \mathrm{~cm}$ soil depth.

Figure 5.3 shows the relationship between the soil properties in the gallery forest (upper panel) and PLU (lower panel) areas in the cerrado and pasture catchments. As expected, in both catchments the total porosity inversely correlates with the bulk density, and a high correlation $(0.98, p<.0001)$ between the microporosity and the field capacity. The microporosity and macroporosity in both catchments exhibited comparable values, with a predominance of the macroporosity between 60 and $70 \%$ of the total porosity. In the PLU areas of the cerrado and pasture catchments, there is 
a positive correlation between the macroporosity and $\mathrm{K}_{\text {sat }}$ of $0.74(p<.0001)$ and 0.68 $(p<.0001)$, respectively.

Table 5.3 Summary of the soil properties.

\begin{tabular}{|c|c|c|c|c|c|c|c|c|c|c|}
\hline Catchment & $\begin{array}{l}\text { Depth } \\
\text { interval } \\
(\mathrm{cm})\end{array}$ & $\mathrm{BD}\left(\mathrm{g} \mathrm{cm}^{-3}\right)$ & $\mathrm{P}(\%)$ & $\mathrm{MaP}(\%)$ & $\operatorname{MiP}(\%)$ & FC (\%) & $\mathrm{K}_{\text {sat }}\left(\mathrm{mm} \mathrm{h}^{-1}\right)$ & Sand (\%) & Silt (\%) & Clay (\%) \\
\hline \multirow{4}{*}{ Cerrado } & $0-10$ & $\begin{array}{l}1.43 \pm 9 \% \\
(1.43 \pm 9 \%)\end{array}$ & $\begin{array}{l}9.2 \pm 8 \% \\
49.4 \pm 10 \%)\end{array}$ & $\begin{array}{l}31.8 \pm 12 \% \\
(26.9 \pm 13 \%)\end{array}$ & $\begin{array}{l}17.4 \pm 35 \% \\
(22.5 \pm 36 \%)\end{array}$ & $\begin{array}{l}15.9 \pm 36 \% \\
(20.5 \pm 40 \%)\end{array}$ & $\begin{array}{l}559.5 \pm 38 \% \\
(361.1 \pm 15 \%)\end{array}$ & $\begin{array}{l}85.8 \pm 10 \% \\
(83.7 \pm 8 \%)\end{array}$ & $\begin{array}{l}2.4 \pm 95 \% \\
(2.64 \pm 109 \%)\end{array}$ & $\begin{array}{l}11.9 \pm 54 \% \\
(13.6 \pm 27 \%)\end{array}$ \\
\hline & $10-20$ & $\begin{array}{l}1.47 \pm 6 \% \\
(1.55)\end{array}$ & $\begin{array}{l}5.8 \pm 5 \% \\
75.7)\end{array}$ & $\begin{array}{l}30.8 \pm 18 \% \\
(28.3)\end{array}$ & $\begin{array}{l}15.0 \pm 32 \% \\
(17.5)\end{array}$ & $\begin{array}{l}13.2 \pm 37 \% \\
(16.1)\end{array}$ & $\begin{array}{l}611.7 \pm 45 \% \\
(363.4)\end{array}$ & $\begin{array}{l}88.9 \pm 2 \% \\
(81.3 \pm 9 \%)\end{array}$ & $\begin{array}{l}1.5 \pm 75 \% \\
(3.73 \pm 78 \%)\end{array}$ & $\begin{array}{l}9.6 \pm 10 \% \\
(15.0 \pm 29 \%)\end{array}$ \\
\hline & $20-40$ & $1.52 \pm 4 \%$ & $2.9 \pm 7 \%$ & $27.0 \pm 18 \%$ & $15.9 \pm 32 \%$ & $14.7 \pm 32 \%$ & $515.56 \pm 56 \%$ & $87.4 \pm 1 \%$ & $1.3 \pm 37 \%$ & $11.3 \pm 7 \%$ \\
\hline & $40-60$ & $1.51 \pm 3 \%$ & $2.1 \pm 2 \%$ & $25.2 \pm 24 \%$ & $16.9 \pm 36 \%$ & $15.6 \pm 36 \%$ & $509.6 \pm 33 \%$ & $86.2 \pm 1 \%$ & $1.9 \pm 49 \%$ & $11.9 \pm 10 \%$ \\
\hline \multirow{4}{*}{ Pasture } & $0-10$ & $\begin{array}{l}1.56 \pm 3 \% \\
(1.23 \pm 10 \%)\end{array}$ & $\begin{array}{l}4.4 \pm 3 \% \\
53.5 \pm 4 \%)\end{array}$ & $\begin{array}{l}28.1 \pm 8 \% \\
(33.0 \pm 9 \%)\end{array}$ & $\begin{array}{l}16.4 \pm 10 \% \\
(20.4 \pm 16 \%)\end{array}$ & $\begin{array}{l}15.5 \pm 10 \% \\
(19.3 \pm 19 \%)\end{array}$ & $\begin{array}{l}399.0 \pm 40 \% \\
(297.3 \pm 52 \%)\end{array}$ & $\begin{array}{l}88.4 \pm 1 \% \\
(86.0 \pm 2 \%)\end{array}$ & $\begin{array}{l}1.5 \pm 40 \% \\
(2.1 \pm 8 \%)\end{array}$ & $\begin{array}{l}10.1 \pm 9 \% \\
(11.9 \pm 12 \%)\end{array}$ \\
\hline & $10-20$ & $\begin{array}{l}1.57 \pm 3 \% \\
(1.37 \pm 3 \%)\end{array}$ & $\begin{array}{l}5.7 \pm 3 \% \\
49.8 \pm 5 \%)\end{array}$ & $\begin{array}{l}32.1 \pm 5 \% \\
(32.0 \pm 10 \%)\end{array}$ & $\begin{array}{l}13.6 \pm 10 \% \\
(17.8 \pm 9 \%)\end{array}$ & $\begin{array}{l}12.9 \pm 9 \% \\
(16.6 \pm 13 \%)\end{array}$ & $\begin{array}{l}655.6 \pm 15 \% \\
(666.5 \pm 46 \%)\end{array}$ & $\begin{array}{l}89.2 \pm 1 \% \\
(86.6 \pm 2 \%)\end{array}$ & $\begin{array}{l}0.9 \pm 97 \% \\
(2.1 \pm 48 \%)\end{array}$ & $\begin{array}{l}9.9 \pm 10 \% \\
(11.3 \pm 22 \%)\end{array}$ \\
\hline & $20-40$ & $\begin{array}{l}1.56 \pm 3 \% \\
(1.41 \pm 3 \%)\end{array}$ & $\begin{array}{l}6.4 \pm 4 \% \\
50.3 \pm 1 \%)\end{array}$ & $\begin{array}{l}32.9 \pm 7 \% \\
(33.6 \pm 7 \%)\end{array}$ & $\begin{array}{l}13.5 \pm 10 \% \\
(16.7 \pm 16 \%)\end{array}$ & $\begin{array}{l}12.8 \pm 10 \% \\
(15.8 \pm 18 \%)\end{array}$ & $\begin{array}{l}705.1 \pm 17 \% \\
(611.3 \pm 25 \%)\end{array}$ & $\begin{array}{l}87.8 \pm 1 \% \\
(86.7 \pm 2 \%)\end{array}$ & $\begin{array}{l}1.7 \pm 28 \% \\
(1.9 \pm 27 \%)\end{array}$ & $\begin{array}{l}10.5 \pm 5 \% \\
(11.4 \pm 14 \%)\end{array}$ \\
\hline & $40-60$ & $\begin{array}{l}1.52 \pm 3 \% \\
(1.44 \pm 4 \%)\end{array}$ & $\begin{array}{l}3.0 \pm 6 \% \\
46.5 \pm 11 \%)\end{array}$ & $\begin{array}{l}28.8 \pm 7 \% \\
(30.2 \pm 12 \%)\end{array}$ & $\begin{array}{l}14.3 \pm 6 \% \\
(16.3 \pm 10 \%)\end{array}$ & $\begin{array}{l}13.4 \pm 8 \% \\
(15.7 \pm 11 \%)\end{array}$ & $\begin{array}{l}510.4 \pm 30 \% \\
(411.8 \pm 24 \%)\end{array}$ & $\begin{array}{l}88.6 \pm 1 \% \\
(88.8 \pm 2 \%)\end{array}$ & $\begin{array}{l}1.3 \pm 39 \% \\
(1.4 \pm 67 \%)\end{array}$ & $\begin{array}{l}10.1 \pm 10 \% \\
(9.8 \pm 6 \%)\end{array}$ \\
\hline
\end{tabular}

BD = Bulk Density, TP = Total Porosity, MaP = Macroporosity, MiP = Microporosity, FC = Field Capacity.

Results are expressed in terms of average and relative standard deviation. The results between parentheses are exclusively for the gallery forest areas, and the results without parentheses are related to the Predominant Land Use (PLU) areas of each microcatchment.

The $\mathrm{K}_{\text {sat }}$ distribution for the catchments is shown in Fig 5.4. The $\mathrm{K}_{\text {sat }}$ values found in the $0-10 \mathrm{~cm}$ soil depth in the PLU areas of the cerrado $\left(559.5 \pm 38 \% \mathrm{~mm} \mathrm{~h}^{-1}\right)$ and pasture $\left(399 \pm 40 \% \mathrm{~mm} \mathrm{~h}^{-1}\right)$ catchments are significantly different $(p<.05)$. Martínez and Zink (Martínez et al., 2004) and Zimmerman et al. (Zimmermann et al., 2006) also found significantly smaller infiltration rates in pasturelands when compared to nearby areas covered by natural forests. In relation to the rainfall intensities in these catchments, the $\mathrm{K}_{\text {sat }}$ indicate a high infiltration capacity in both catchments, which generally exceeds the rainfall intensities. This is related to the sandy soil texture and the high macroporosity, which is typical for Arenosols. Our results are in accordance with findings of Scheffler et al. (Scheffler et al., 2011) who analyzed soil hydraulic properties of catchments with sandy-loam soil texture ca. $450 \mathrm{~km}$ from our study area and found $\mathrm{K}_{\text {sat }}$ values up to $1,200 \mathrm{~mm} \mathrm{~h}^{-1}$. 


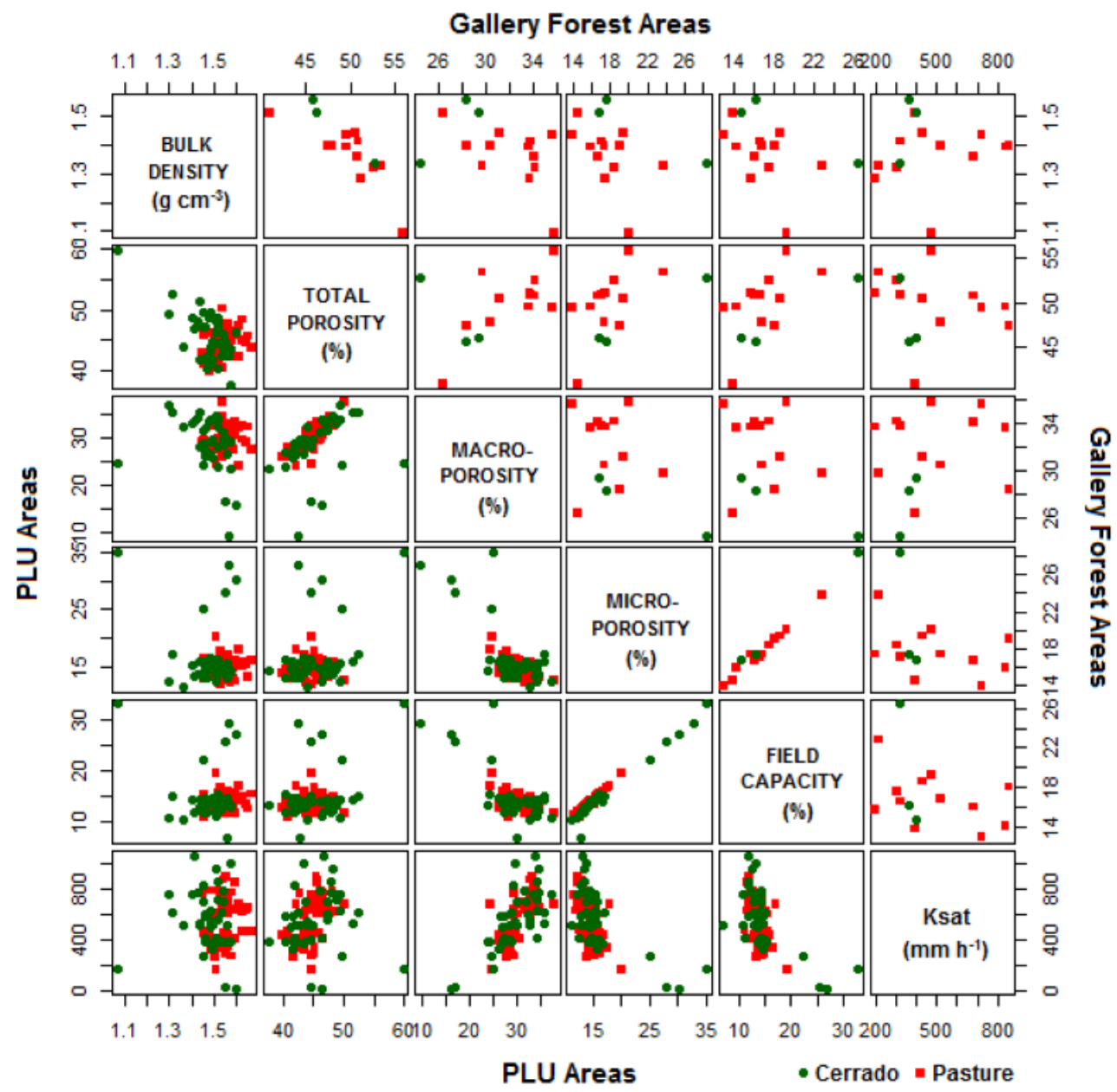

Figure 5.3 Scatter-plot matrix of soil properties values in the gallery forest (upper panel) and PLU (lower panel) areas in the cerrado and pasture catchments.

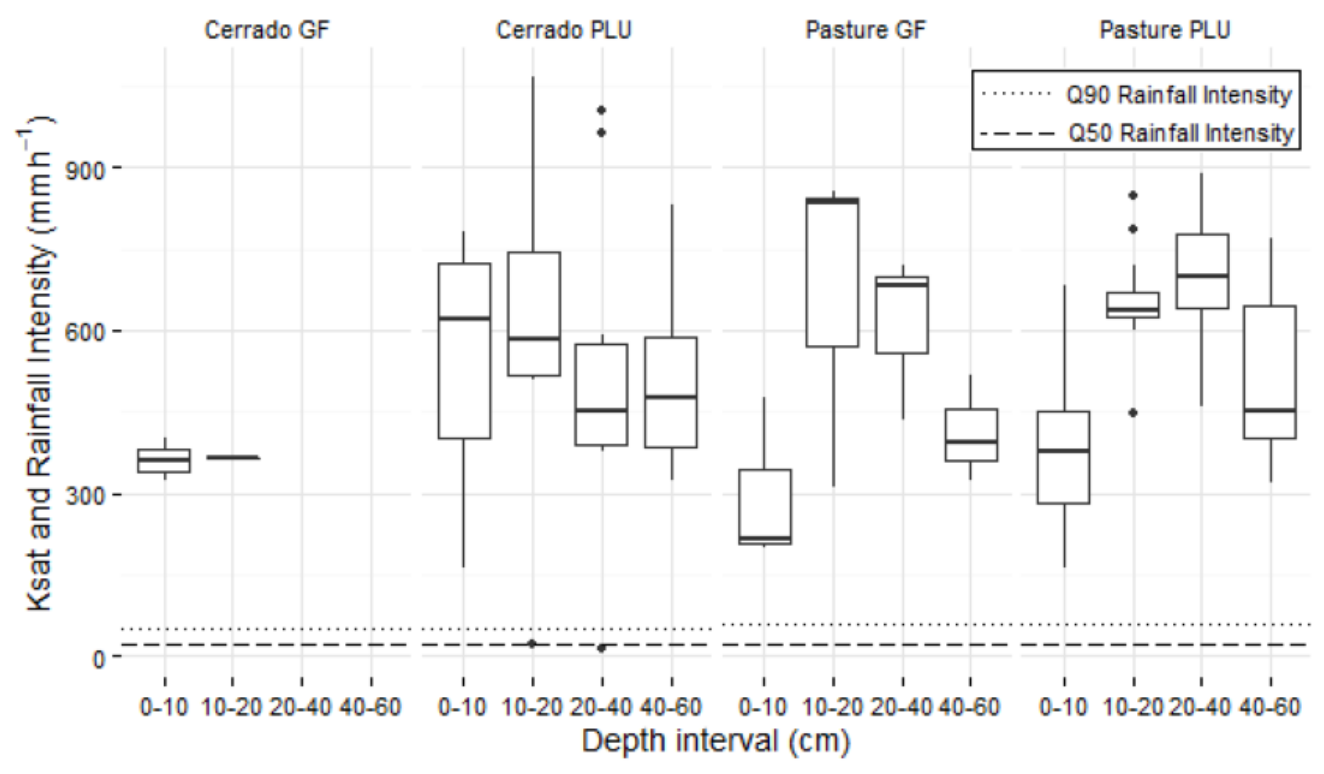

Figure 5.4 Boxplot of the $\mathrm{K}_{\text {sat }}$ results, and the $50^{\text {th }}$ and $90^{\text {th }}$ percentiles of the rainfall intensity in the cerrado and pasture catchments. 


\subsubsection{Rainfall characteristics}

The monthly total rainfall in each micro-catchment during the two-year study period is shown in Fig 5.5. Between October 2012 and September 2014, the total rainfall was $3,392 \mathrm{~mm}$ in the cerrado catchment, and 3,560 $\mathrm{mm}$ in the pasture catchment. For both catchments, the wet season in 2013-2014 had a smaller contribution to the total annual rainfall than in 2012-2013, which was caused by some atypical rainstorms in the dry season of 2014. The greatest daily rainfall values were recorded on March 2, 2014, for the cerrado catchment, and on January 30,2013 , for the pasture catchment, both at $64 \mathrm{~mm} \mathrm{~d}^{-1}$.

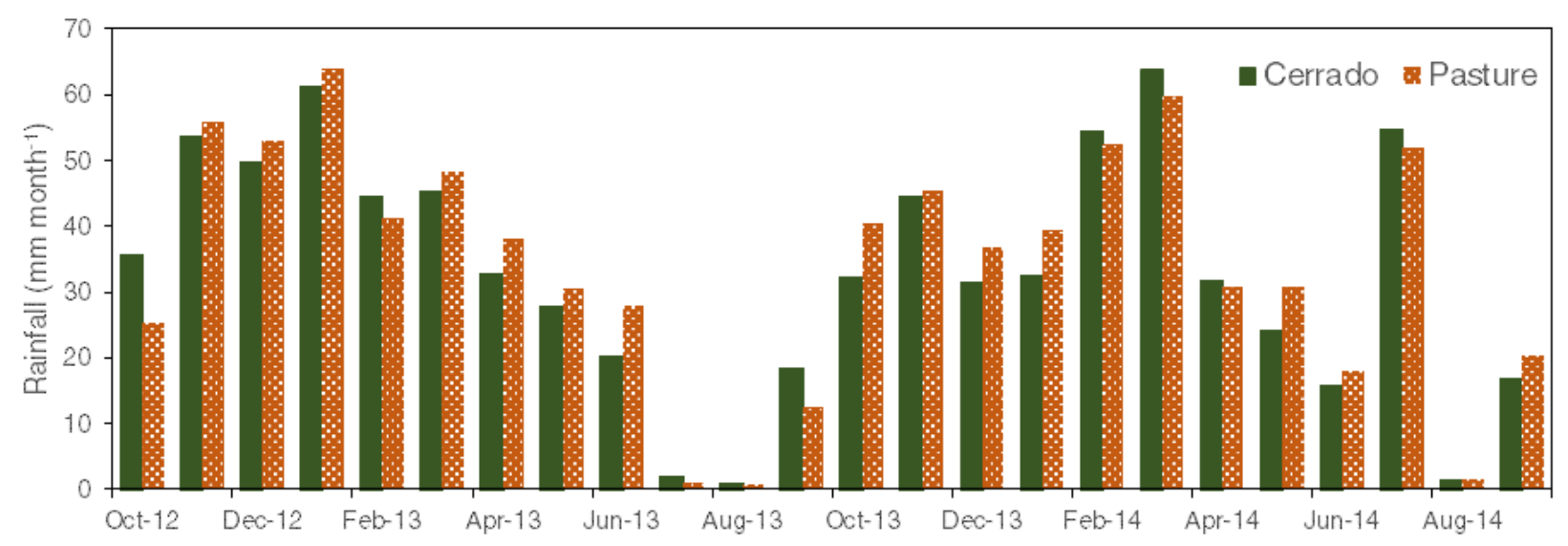

Figure 5.5 Monthly rainfall per catchment.

The difference between the catchments' daily rainfall in the study period is not significant, showing a coefficient of determination of $0.93(p<.0001)$. We also could not find any significant difference in the rainfall intensity patterns between the cerrado and pasture catchments. In both catchments, the majority of the rainstorms occurred between noon and mid-afternoon with a mean intensity of $28 \mathrm{~mm} \mathrm{~h}^{-1}$, peaks intensities up to $130 \mathrm{~mm} \mathrm{~h}^{-1}$, and a duration between 30 and $90 \mathrm{~min}$.

\section{Evapotranspiration}

The daily values of $\mathrm{E}_{\mathrm{T}}$ are shown in Fig 5.6. The daily $\mathrm{E}_{\mathrm{T}}$ was significantly greater in the cerrado catchment $(p<.0001)$. In the PLU areas, the average $E_{T}$ was $2.7 \mathrm{~mm} \mathrm{~d}^{-1}$ for the cerrado catchment and $1.7 \mathrm{~mm} \mathrm{~d}^{-1}$ for the pasture catchment. In the gallery forest areas, average daily $E_{T}$ was 3.3 and $2.7 \mathrm{~mm} \mathrm{~d}^{-1}$ for the cerrado and pasture catchments, respectively. The average annual $\mathrm{E}_{\mathrm{T}}$ was $1,004 \pm 24 \% \mathrm{~mm}$ in the cerrado catchment and $639 \pm 31 \% \mathrm{~mm}$ pasture catchment. Our results are comparable to $E_{T}$ 
values for cerrado sensu stricto vegetation ranging between 822 and $1,010 \mathrm{~mm} \mathrm{yr}^{-1}$ found by Giambelluca et al. (Giambelluca et al., 2009), Oliveira et al. (Oliveira et al., 2014), and Dias et al. (Dias et al., 2015) who applied eddy-covariance measurements, remoting sensing techniques, and a water balance model, respectively. Da Silva et al. (da Silva et al., 2015) found maximum values between 6 and $7 \mathrm{~mm} \mathrm{~d}^{-1}$ during the wet season for an area covered by cerrado vegetation (mostly sensu stricto type), which are in the same range of the maximum values we found.

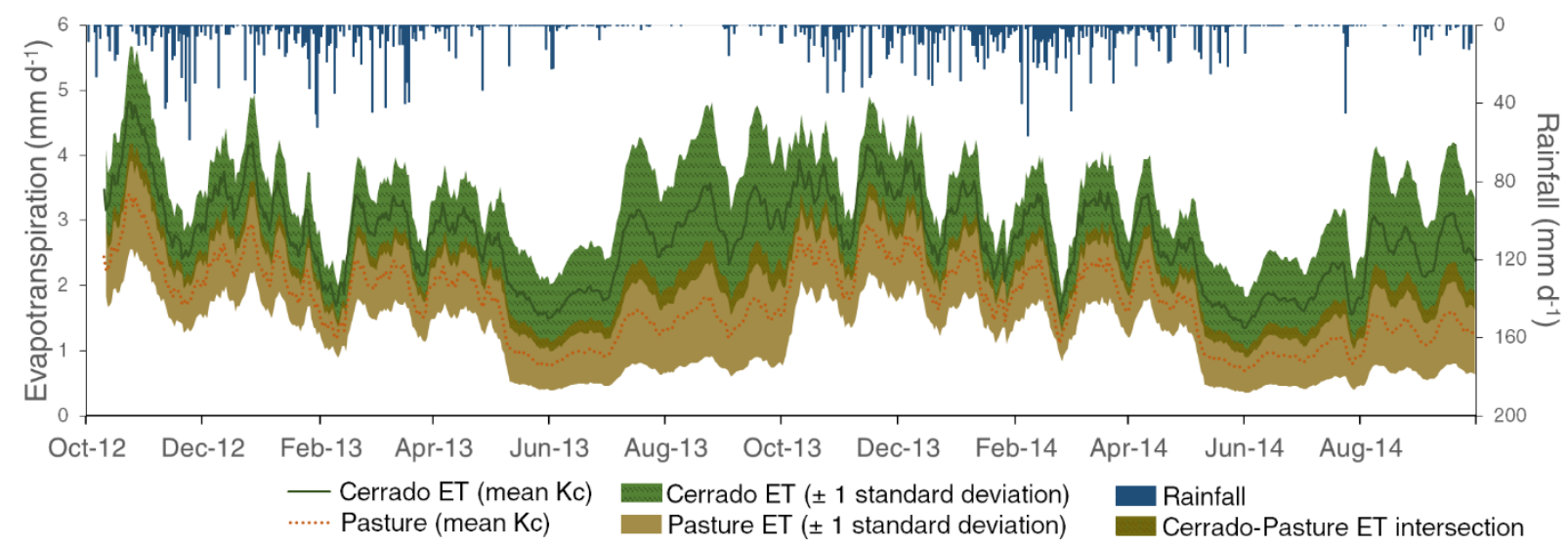

Figure 5.6 10-day moving average of evapotranspiration, and daily areal average rainfall for the cerrado and pasture catchments.

Our ET results for the grassland vegetation are in accordance with Dias et al. (Dias et al., 2015) who used a water balance simulation model and found $E_{T}$ at $567 \mathrm{~mm} \mathrm{yr}^{-1}$ in the Cerrado-Amazon ecotone, and with Andrade et al. (Andrade et al., 2014) who used remote sensing techniques and found the daily $E_{T}$ varying between 1.5 and $2 \mathrm{~mm} \mathrm{~d}^{-1}$ in the Cerrado biome. In a macro-scale analysis for the Mato Grosso state, Lathuillière et al. (Lathuillière et al., 2012) reported a range of greater values (822-889 $\mathrm{mm} \mathrm{yr}^{-1}$ ) for pasturelands compared to our study; we attribute this difference to the state of degradation of the grassland vegetation in the pasture catchment, which is accredited to reduce the $\mathrm{E}_{\mathrm{T}}$ (Andrade et al., 2014).

Streamflow

The daily discharge values are shown in Fig 5.7. Due to equipment failure, this time series includes some data gaps. The mean stream discharge was $1.24 \mathrm{~mm} \mathrm{~d}^{-1}$ in the cerrado catchment, and $1.96 \mathrm{~mm} \mathrm{~d}^{-1}$ in the pasture catchment. During the wet season, the mean stream discharge was $1.49 \mathrm{~mm} \mathrm{~d}^{-1}$ in the cerrado catchment, and $2.20 \mathrm{~mm}$ 
$\mathrm{d}^{-1}$ in the pasture catchment. In the dry season, the stream discharge was $0.92 \mathrm{~mm} \mathrm{~d}^{-}$ ${ }^{1}$ in the cerrado catchment, and $1.58 \mathrm{~mm} \mathrm{~d}^{-1}$ in the pasture catchment.

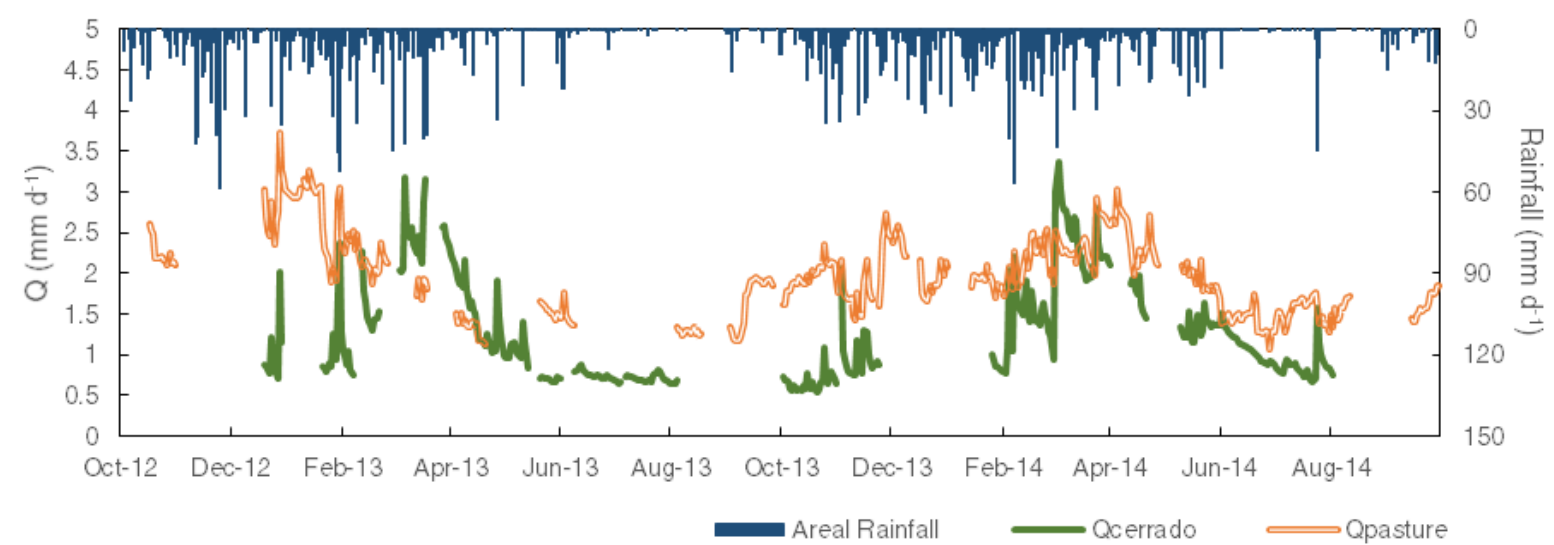

Figure 5.7 Daily discharges and areal average rainfall for the cerrado and pasture catchments.

Table 5.4 shows a summary of the hydrological indices derived for the study catchments. During the two-year study period, the daily streamflow was significantly greater $(p<.0001)$ in the pasture catchment $(1,416 \pm 7 \% \mathrm{~mm})$ compared to the cerrado catchment $(914 \pm 18 \% \mathrm{~mm})$. We found $R_{c}$ values of 0.27 for the cerrado and 0.40 for the pasture. Dias et al. (2015) found $R_{c}$ of 0.25 for a cerrado catchment and 0.58 for a pasture catchment using a model based on water balance equations while Tomasella et al. (Tomasella et al., 2009) reported a $R_{c}$ of 0.38 for a pasture catchment. The flashiness indices are generally small, particularly for the pasture catchment with indices as low as 0.05 . The catchment's streamflow decreased by $27 \%$ from the wet to the dry season while the decrease in the cerrado catchment was $40 \%$.

Table 5.4 Total streamflow and hydrological indices.

\begin{tabular}{ccccc}
\hline & \multicolumn{2}{c}{ Cerrado } & \multicolumn{2}{c}{ Pasture } \\
\cline { 2 - 5 } & $2012-2013$ & $2013-2014$ & $2012-2013$ & $2013-2014$ \\
\hline $\begin{array}{c}\text { Mean } \\
\text { streamflow } \\
\left(\mathrm{mm} \mathrm{yr}^{-1}\right)\end{array}$ & 453 & 461 & 724 & 692 \\
\hline $\begin{array}{c}\text { Runoff } \\
\text { Coefficient } \\
(\text { Rc })\end{array}$ & 0.29 & 0.25 & 0.45 & 0.35 \\
\hline $\begin{array}{c}\text { Flashiness } \\
\text { Baseflow }\end{array}$ & 0.1145 & 0.1015 & 0.0567 & 0.0517 \\
\hline $\begin{array}{c}\text { Index } \\
(\text { BFI) }\end{array}$ & 0.96 & 0.97 & 0.98 & 0.96 \\
\hline
\end{tabular}


The FDCs (Fig 5.8) of the two catchments show differences in the low flows (Q95) with the cerrado catchment exhibiting the smaller values and greater decrease. Flows with $20 \%$ or greater probability of exceedance are higher in the pasture than in the cerrado by an average of $82 \%$. The FDCs curves show a flat slope from the middle to the low flows, supporting that low flows are sustained by the baseflow contribution. This is confirmed by the BFI results, which show a high baseflow contribution to total streamflow in both catchments, with ratios higher than $95 \%$. Total quickflow contribution under $5 \%$ was also found in other areas of Cerrado at plot (Oliveira et al., 2015) and micro-catchment scales (Silva and Oliveira, 1999; Lima, 2000; Alencar et al., 2006).

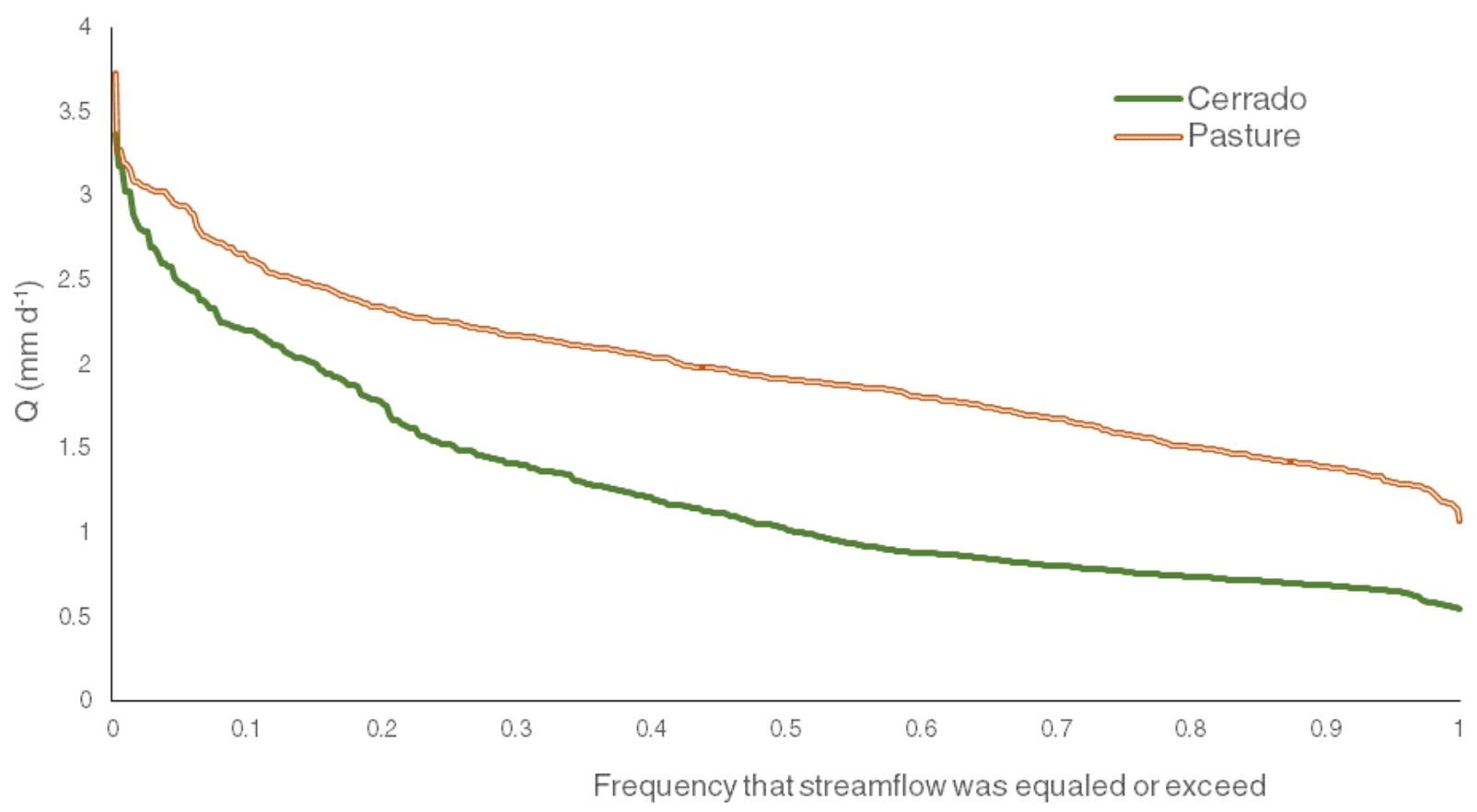

Figure 5.8 Flow-duration curves of daily discharge for the cerrado and pasture catchments.

\subsection{Discussion}

The pasture catchment showed significantly greater bulk densities and smaller $\mathrm{K}_{\text {sat }}$ and total porosity at the topsoil. Findings like these have been attributed to soil compaction as a consequence of deforestation, cattle grazing and machinery use, e.g. (Greenwood and McKenzie, 2001; De Oliveira et al., 2004; Hamza and Anderson, 2005; Drewry et al., 2008). Although we found significantly smaller $\mathrm{K}_{\text {sat }}$ values in the pasture catchment, these values exceed the observed peak rainfall intensities, which are likely to restrain Hortonian overflow generation and consequently limit the 
quickflow contribution $(<5 \%)$ to the streamflow in both catchments. Zimmerman et al. (Zimmermann et al., 2006) found similar results in a study on deforested areas in the Amazon basin, showing that the $\mathrm{K}_{\text {sat }}$ reduction due to land-use change had no significant impact on quickflow generation in those areas. We associate the $K_{\text {sat }}$ results to the high macroporosity in both catchments, which has a known effect on soil permeability (Logsdon et al., 1990; Lin et al., 1998). While macroporosity values around $10 \%$ maintain adequate soil permeability (Carter, 1988), our results show a macroporosity of approximately $30 \%$ for both catchments. The presence of macroporosity is related to preferential flow (Diab et al., 1988), which often limits the overflow generation. In fact, our hydrograph analysis shows that baseflow is a major driver of streamflow in both catchments, with BFI over $95 \%$.

Table 5.5 shows a compilation of the daily and annual $E_{T}$ and $Q$ results for both catchments. The cerrado catchment had the greater $\mathrm{E}_{\mathrm{T}}$ compared with the pasture catchment. While the mean $\mathrm{E}_{\mathrm{T}}$ decreased $45 \%$ in the pasture catchment from the wet to the dry season, the $\mathrm{E}_{\mathrm{T}}$ in the cerrado catchment was reduced by $24 \%$. We attribute this result to the canopy cover in the cerrado vegetation with leaf area index values ranging from approximately 0.7 to 1.1 throughout the year (Hoffmann et al., 2005) and with root lengths sufficient to reach deep soil horizons (Canadell et al., 1996), which ensures $E_{\text {T }}$ rates at $2.32 \pm 24 \% \mathrm{~mm} \mathrm{~d}^{-1}$ during the dry season.

Table 5.5 Daily and annual evapotranspiration and streamflow rates.

\begin{tabular}{ccccccc}
\hline Catchment & \multicolumn{3}{c}{ Evapotranspiration } & \multicolumn{3}{c}{ Streamflow } \\
\cline { 2 - 7 } & $\begin{array}{c}\text { Dry } \\
\left(\mathrm{mm} \mathrm{d}^{-1}\right)\end{array}$ & $\begin{array}{c}\text { Wet } \\
\left(\mathrm{mm} \mathrm{d}^{-1}\right)\end{array}$ & $\begin{array}{c}\text { Annual } \\
\left(\mathrm{mm} \mathrm{yr}^{-1}\right)\end{array}$ & $\begin{array}{c}\text { Dry } \\
\left(\mathrm{mm} \mathrm{d}^{-1}\right)\end{array}$ & $\begin{array}{c}\text { Wet } \\
\left(\mathrm{mm} \mathrm{d}^{-1}\right)\end{array}$ & $\begin{array}{c}\text { Annual } \\
\left(\mathrm{mm} \mathrm{yr}^{-1}\right)\end{array}$ \\
\hline Cerrado & $2.32 \pm 24 \%$ & $3.06 \pm 26 \%$ & $1,004 \pm 24 \%$ & $0.92 \pm 27 \%$ & $1.49 \pm 46 \%$ & $457 \pm 18 \%$ \\
\hline Pasture & $1.19 \pm 44 \%$ & $2.15 \pm 27 \%$ & $639 \pm 31 \%$ & $1.58 \pm 15 \%$ & $2.20 \pm 20 \%$ & $708 \pm 7 \%$ \\
\hline
\end{tabular}

$\mathrm{ET}_{\mathrm{T}}$ is a major component of the water balance in tropical regions (Wohl et al., 2012). As reported in other studies (Bruijnzeel, 2005; Muñoz-Villers and McDonnell, 2013), the differences in Ет between native vegetation and grassland plays a major role in the streamflow dynamics. Our results confirms trend analyses and water balance modelling studies at the macro-scale (das Mortes River basin), which show an increase of streamflow due to the deforestation of the cerrado vegetation (Guzha et al., 2013b, 2013a). In fact, the conversion of native vegetation to croplands and pasturelands in the Mato Grosso state resulted in a 25\% decrease in $\mathrm{E}_{\mathrm{T}}$ (Lathuillière 
et al., 2012), and that water export increases up to fourfold in agricultural areas due to the reduction of $\mathrm{E}_{\mathrm{T}}$ (Neill et al., 2013). Our results are also consistent with those of other studies that reported decreases in $\mathrm{E}_{\top}$ (Dias et al., 2015; Oliveira et al., 2014) and increases in discharge (Coe, Costa, \& Soares-Filho, 2009; Costa et al., 2003; Davidson et al., 2012; de Moraes et al., 2006; Guzha et al., 2015; Hayhoe et al., 2011; Neill et al., 2008, 2011) due to conversion of natural vegetation to grasslands on the Amazonian agricultural frontier.

Results from other tropical catchments studies that show a decrease in dry season streamflow as a consequence of forest conversion (Bruijnzeel, 2004; Ogden et al., 2013) cannot be confirmed in our study in the Cerrado biome. From the wet to the dry season our results showed a greater decrease in streamflow in the cerrado catchment than in the pasture catchment, while the $\mathrm{E}_{\mathrm{T}}$ behaved otherwise with lower decrease in the cerrado catchment. We suggest that this is related to the higher root zone storage capacity of the cerrado vegetation. The deep roots of the cerrado vegetation influence the water balance and appear to be important in proving water for vegetation during the dry season (Oliveira et al., 2005). Indeed, the cerrado vegetation is highly adapted to a long dry season and deeply weathered soils (Hunke et al., 2015a), which is a particular situation that demands more detailed hydrological research in this region. The replacement of the cerrado vegetation with exotic grasses seems to increase the deep seepage and reduce $\mathrm{E}_{\mathrm{T}}$, which in turn will increase the streamflow, especially during the dry season.

\subsection{Conclusions}

We investigated the hydrological responses of two headwater micro-catchments with contrasting land use (cerrado vs. pasture) in the Brazilian Cerrado using field data collected between 2012 and 2014. From our study, we conclude that the conversion of the undisturbed cerrado to pasture caused:

i) Significant soil hydro-physical degradation as indicated by higher bulk density and reduced soil porosity in the pasture catchment in comparison to the cerrado catchment;

ii) An increase in streamflow as shown by the significantly greater daily and annual streamflow values in the pasture catchment. Furthermore, we 
conclude that cerrado conversion to pasture reduced the evapotranspiration.

While our study contributes to understanding of the soil degradation and hydrological processes in this region, we suggest long-term measurements including quantifying changes in groundwater storage in order to better clarify the mechanisms causing the observed behavior in our data.

\section{Acknowledgements}

This research was feasible thanks to the collaboration of field site hosts (Fazenda Gianetta and Fazenda Rancho do Sol). The authors also acknowledge: Jonas Macedo, Norma Bertão and Túlio Santos for the field assistance; Prof. J. Cunha for his advice concerning the SEBAL and METRIC application; and Dr. J. Grotheer for technical support. We also thank the anonymous reviewers for the helpful comments. 


\section{Chapter 6. Impacts of land use and land cover change on stream hydrochemistry in the Cerrado and Amazon biomes}

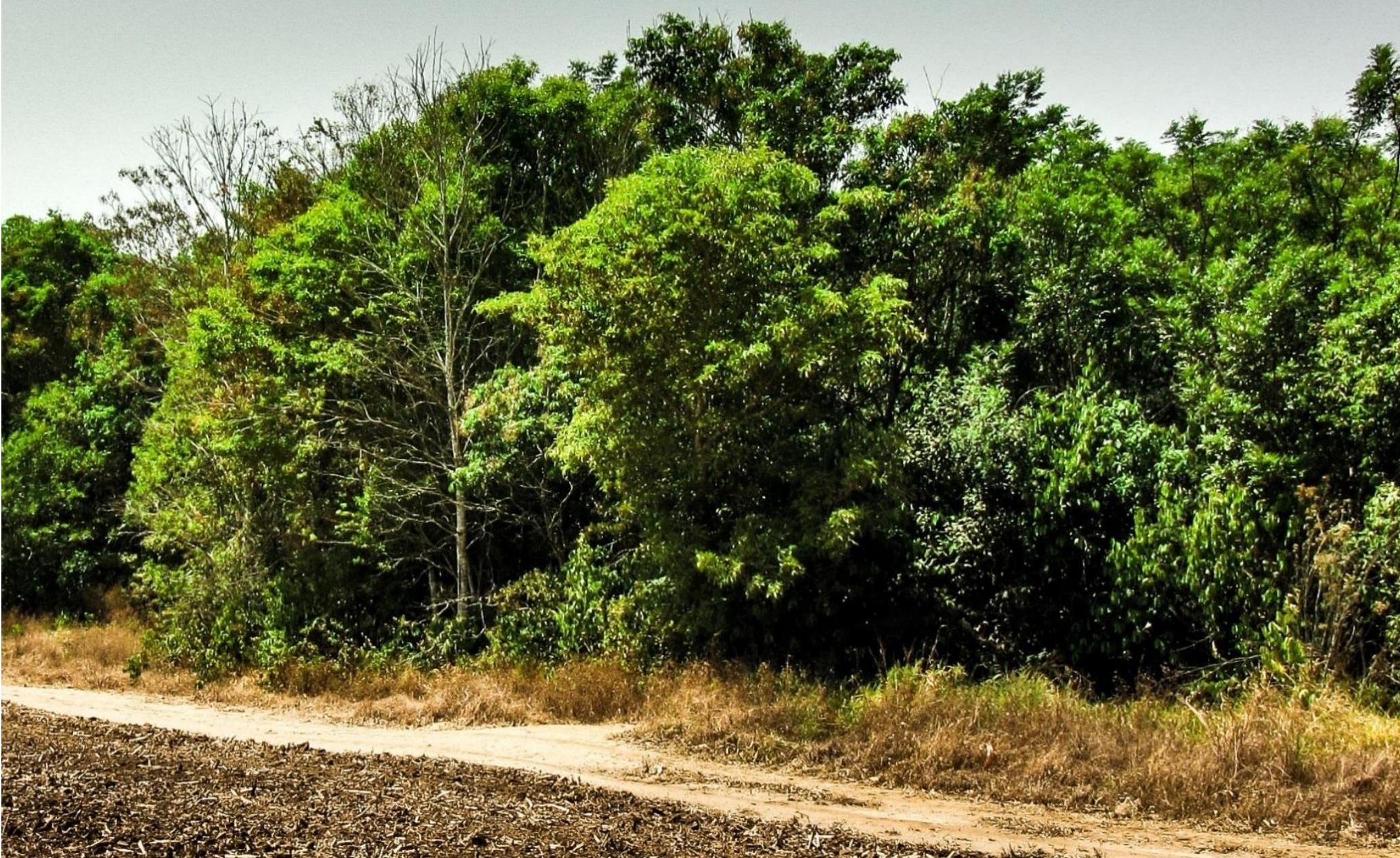

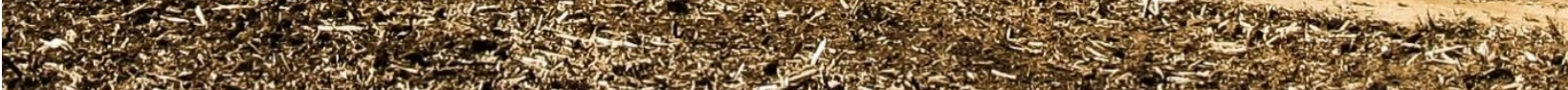

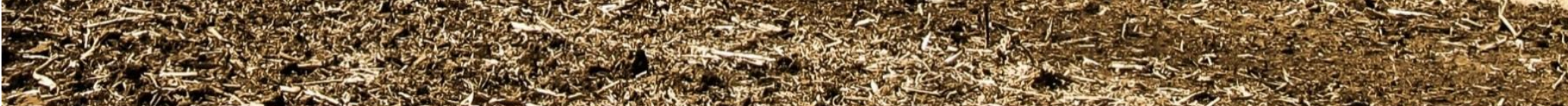

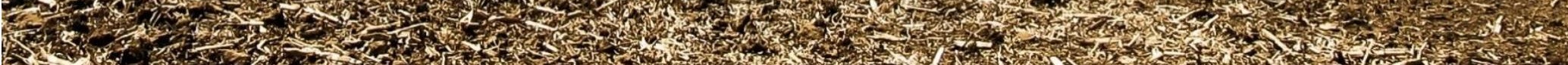

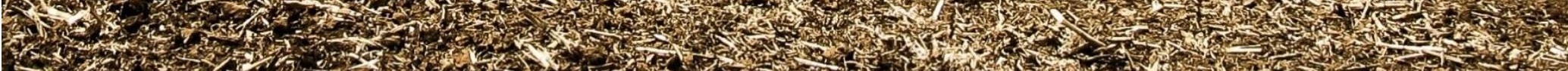
(3.7.

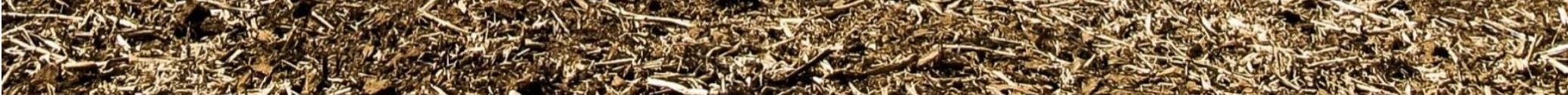
(5)

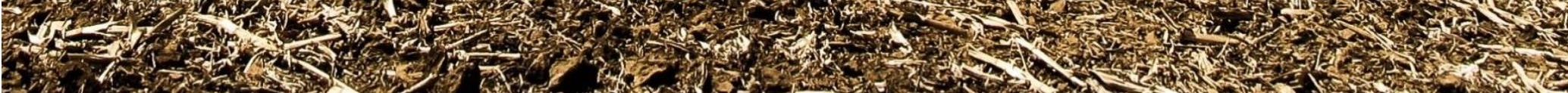

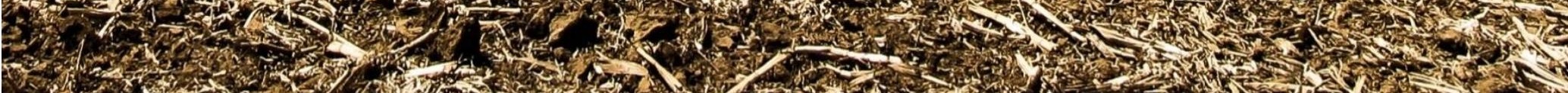

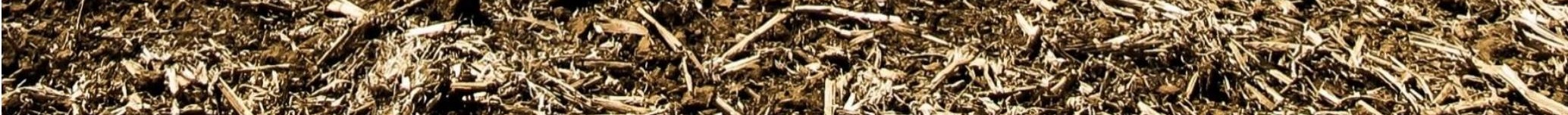
1 


\title{
6. Impacts of land-use and land-cover change on stream hydrochemistry in the Cerrado and Amazon biomes
}

This manuscript is published as: Nóbrega, RLB, Guzha, AC, Lamparter, G, Amorim, RSS, Couto, EG, Hughes, HJ, Jungkunst, HF, Gerold, G. 2018. Impacts of land-use and land-cover change on stream hydrochemistry in the Cerrado and Amazon biomes. Sci. Total Environ. 635, 259-274. DOI:10.1016/j.scitotenv.2018.03.356.

\begin{abstract}
Studies on the impacts of land-use and land-cover change on stream hydrochemistry in active deforestation zones of the Amazon agricultural frontier are limited and have often used low-temporal-resolution datasets. Moreover, these impacts are not concurrently assessed in well-established agricultural areas and new deforestations hotspots. We aimed to identify these impacts using an experimental setup to collect high-temporal-resolution hydrological and hydrochemical data in two pairs of low-order streams in catchments under contrasting land use and land cover (native vegetation vs. pasture) in the Amazon and Cerrado biomes. Our results indicate that the conversion of natural landscapes to pastures increases carbon and nutrient fluxes via streamflow in both biomes. These changes were the greatest in total inorganic carbon in the Amazon and in potassium in the Cerrado, representing a 5.0- and 5.5-fold increase in the fluxes of each biome, respectively. We found that stormflow, which is often neglected in studies on stream hydrochemistry in the tropics, plays a substantial role in the carbon and nutrient fluxes, especially in the Amazon biome, as its contributions to hydrochemical fluxes are mostly greater than the volumetric contribution to the total streamflow. These findings demonstrate that assessments of the impacts of deforestation in the Amazon and Cerrado biomes should also take into account rapid hydrological pathways; however, this can only be achieved through collection of high-temporal-resolution data.
\end{abstract}

\subsection{Introduction}

It has been widely acknowledged that surface conditions of terrestrial ecosystems have strong synergies with hydrological processes (Neill et al., 2008; Rodriguez et al., 2010; Recha et al., 2012; Cuo et al., 2013). These processes are often influenced by land-use practices, which, in turn, can change catchment responses, such as stream hydrochemistry (Öztürk et al., 2013; Salemi et al., 2013; Crossman et al., 2014; Oni et al., 2014; El-Khoury et al., 2015; Vogt et al., 2015). Because of large-scale environmental impacts resulting from the conversion of native habitats into agricultural frontiers (Schiesari et al., 2013), it is fundamental to comprehend how land-use and land-cover (LULC) change influences hydrochemical processes in pristine catchments 
undergoing anthropogenic changes (Jordan et al., 1997; Neill et al., 2013). Therefore, studies have often focused on regions under intensive forest degradation due to agricultural expansion, such as the Brazilian Amazon, to assess the impacts of LULC change on stream hydrochemistry (Dias et al., 2015; Figueiredo et al., 2010b; Germer et al., 2009; Neill et al., 2011; Recha et al., 2013; Williams and Melack, 1997).

The Amazonian agricultural frontier (AAF), also known as the arc of deforestation, extends from the eastern to the southwestern edge of the Brazilian Amazon, comprising a wide area along the Amazon-Cerrado ecotone (Durieux, 2003; Silva et al., 2013; Do Vale et al., 2015). Deforestation in this region has taken place due to agricultural expansion during recent decades, and represents most of the deforestation of the AAF (Fearnside, 2001; Brannstrom et al., 2008; Riskin et al., 2013; Tollefson, 2015). This ongoing change threatens the services provided by native ecosystems, such as the water quantity and quality that sustain aquatic biodiversity and mitigates eutrophication of water bodies (Davidson et al., 2012; Coe et al., 2013; Neary, 2016; Penaluna et al., 2017). However, despite the important contribution of several research initiatives (e.g., Andreae et al., 2015; Lahsen and Nobre, 2007; Satinsky et al., 2014), an understanding of the influence of LULC change on water resources in the Brazilian Amazon region remains limited. Furthermore, the Cerrado biome, where most of the AAF deforestation has occurred (Klink and Machado, 2005), is often not integrated in studies regarding Amazon deforestation; consequently, it is one of the lesser-studied regions in terms of the environmental effects of LULC change resulting from agricultural expansion (Jepson et al., 2010; Hunke et al., 2015a; Oliveira et al., 2015) despite being a biodiversity hotspot for conservation comprised of dry forests, woodland savannas and grasslands (Spera et al., 2016; Strassburg et al., 2017). The conversion of native vegetation to crops and pastures has removed ca. $50 \%$ of the original 2 million $\mathrm{km}^{2}$ in the Cerrado, which is greater than the forest loss in the Amazon biome (Klink and Machado, 2005; Lambin et al., 2013).

The negative impacts on water quality due to LULC change are reported to be a result of interrelated processes (i.e., changes in vegetation, soil and hydrology) that negatively disturbs its land capability, which is the ability of the land to sustain its use (Valle et al., 2014; Valle Junior et al., 2015). On the AAF, soil and hydrological changes have been linked to forest clearing and conversion to pastures (Zimmermann et al., 
2006; Neill et al., 2008). Indeed, LULC change on the AAF has been primarily driven by the expansion of pastures (Armenteras et al., 2013; Schierhorn et al., 2016). After some years, these pastures are often either replaced by cash crop systems (Barona et al., 2010; Cohn et al., 2016) or abandoned due to decreased grass productivity, ultimately reaching advanced stages of degradation (Davidson et al., 2012). Variations in nutrient input into rivers caused by LULC change on the AAF deserve particular attention because of their potential impact on both biogeochemistry and aquatic ecosystem functioning (Neill et al., 2011). Even though rain and dry forests account for ca. $60 \%$ of the net primary production of global terrestrial ecosystems (Grace et al., 2006; Potter et al., 2012), the effects of the impacts of LULC change in these systems are not well studied as they are for other regions of the world (Luke et al., 2017).

The initial effects of LULC change on the hydrochemistry of rivers have often been observed in low-order streams (Richey et al., 1997; Neill et al., 2001; Hope et al., 2004), which connect the terrestrial environment to large rivers and integrate environmental processes, especially landscapes undergoing change (Alexander et al., 2000; Moreira-Turcq et al., 2003). These characteristics qualify small streams as sensitive indicators of changes in ecosystems due to LULC change and allow their use as important references in carbon exportation studies and as early warning systems for ecological change (Christophersen et al., 1994). Although many studies have evaluated the dynamics of carbon and nutrients in streams in several regions of the world (e.g. Southeastern USA (Marchman et al., 2015), subtropical China (Yan et al., 2015), Germany (Strohmeier et al., 2013) and Canada (Jollymore et al., 2012)), studies of carbon export dynamics in low-order tropical catchments are still scarce (de Paula et al., 2016). There is increasing research interest in high-temporal-resolution data collection in low-order fluvial systems that should also be taken into account in hydrochemistry studies (Hughes et al., 2005; Richey et al., 2011; Wohl et al., 2012) due to their importance to the global carbon dynamics (Bass et al., 2014).

The dynamics of stream hydrochemistry that have remained largely invisible due to the monitoring schemes that only consider weekly or monthly sampling (Kirchner and Neal, 2013), have been gradually unveiled due to approaches that use subdaily sampling intervals (Tang et al., 2008). However, the high-frequency water sampling 
approach that has been shown to be useful for these studies in temperate regions (Clark et al., 2007) has been discredited in tropical regions (Chaussê et al., 2016). Moreover, findings in Amazonian headwater streams that have used subhourly sampling routines have found that the conversion of forests to fertilized agricultural lands changed neither the stream water chemistry nor nutrient output per unit of catchment area (Neill et al., 2017; Riskin et al., 2017).

Our study aims to identify the differences in stream carbon and nutrient (CAN) concentrations and output fluxes during prevalent baseflow and stormflow conditions in headwater catchments under contrasting LULC (native vegetation vs. pasture), thereby contributing to the understanding of CAN drivers in low-order streams on the AAF. Our hypothesis is that LULC change is impacting stream hydrochemistry in active deforestation zones of the Amazon and Cerrado biomes, with the stormflow, which is often neglected in studies in these regions, as a substantial contributor to the total CAN fluxes.

\subsection{Study area}

Our study follows the space-for-time substitution approach to compare adjacent headwater catchments with different LULC but with similar characteristics, i.e. slope, geology, soils, aspect and climate (Troch et al., 2015). Studies have often used this approach to understand the effects of vegetation and land use on hydrological responses in small catchments (Brown et al., 2005; de Moraes et al., 2006; Germer et al., 2010; Roa-García et al., 2011; Muñoz-Villers and McDonnell, 2013; Ogden et al., 2013). It has also been applied to compare the impacts of LULC change on stream hydrochemistry of contrasting catchments (Zhao et al., 2010; Sun et al., 2013).

We used two pairs of microcatchments on the AAF (Fig. 6.1) with contrasting LULC. Each pair of catchments consists of a catchment with predominantly native vegetation land cover and a catchment with predominantly pasture land cover used for extensive cattle ranching. One pair of catchments is in the municipality of Novo Progresso (Brazilian state of Pará), which is a hotspot of deforestation in the Amazon biome (Rufin et al., 2015; Pinheiro et al., 2016), and the other pair is in the municipality of Campo Verde (Brazilian state of Mato Grosso), which is a region that has been massively deforested since the 1970s and is now a well-established agro-industrial 
area in the Cerrado biome. The catchments in Novo Progresso, hereafter referred to as the Amazonian catchments, are in the Jamanxim River watershed, which is one of the major southern subtributaries of the Amazon River. The catchments in Campo Verde, hereafter referred to as the Cerrado catchments, are in the das Mortes River watershed, the principal tributary of the Araguaia River.

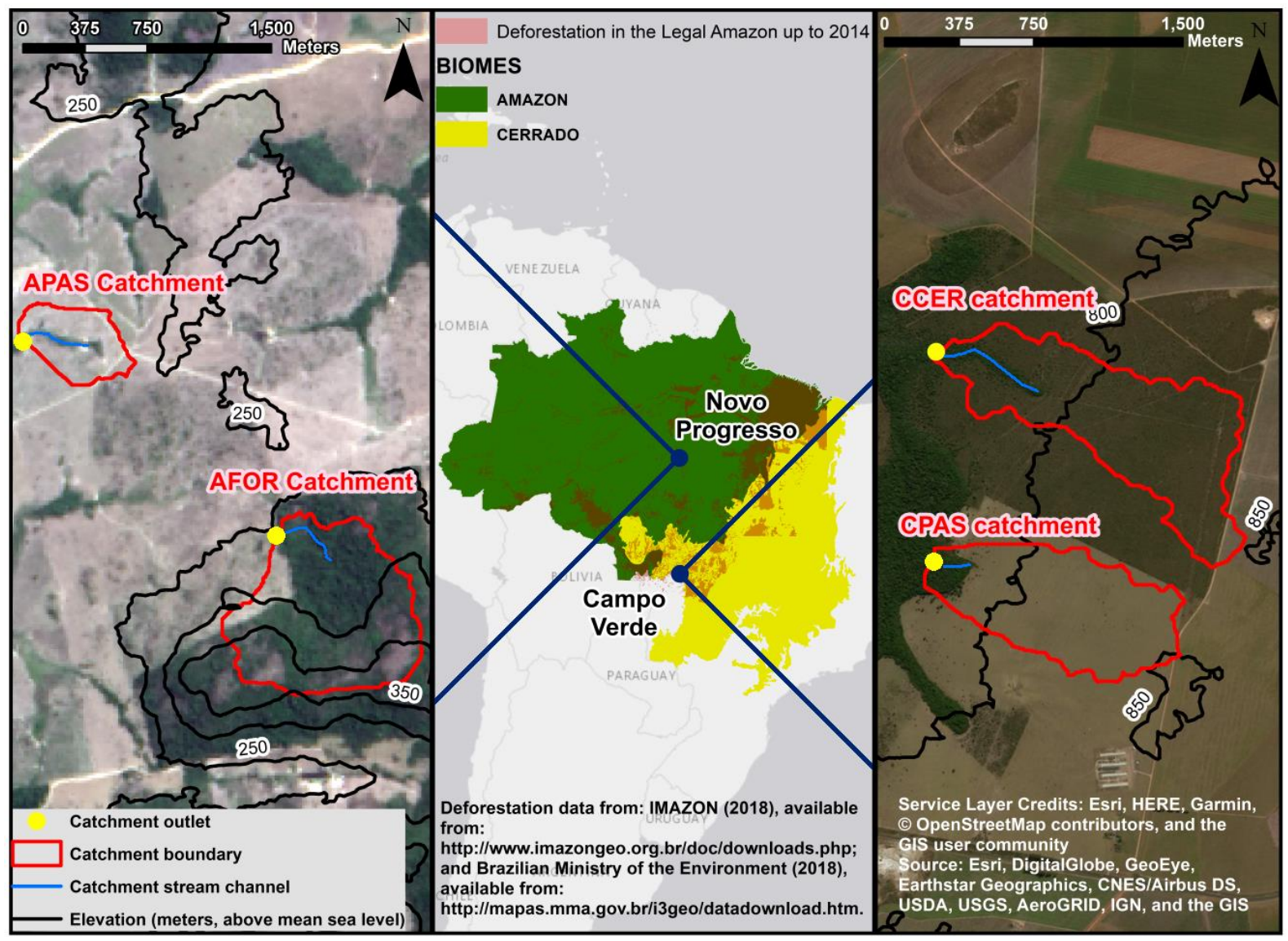

Figure 6.1 Study areas in the Amazon and Cerrado biomes.

The Amazonian catchments consist of one catchment covered with evergreen rainforest, with sings of logging and tree regrowth (AFOR), and another catchment covered by degraded pasture grassland (APAS). The AFOR catchment is the only catchment that is drained by a non-perennial stream; it typically flows from November to July. The Cerrado catchments are approximately $200 \mathrm{~m}$ apart, consisting of one catchment covered with cerrado sensu stricto vegetation (CCER) and another catchment covered by pasture grassland with signs of degradation (CPAS). The cerrado sensu stricto is characterized as dense orchard-like vegetation consisting of many species of grasses and sedges, and mixed with a great diversity of forbs and trees with an average height of 6 m (Goodland, 1971; Goodland and Pollard, 1973; 
Canadell et al., 1996; Ratter et al., 1997; Furley, 1999). The APAS catchment was established in 1984, and the CPAS catchment was established in 1994. Both pasture catchments are mostly covered by grasses (Brachiaria grass species) that exhibit low productivity rates. Lime (calcium carbonate, $\mathrm{CaCO}_{3}$ ) was applied in the pasture catchments several years before the study period. The climate in the Amazonian catchments is humid tropical, with a mean precipitation of ca. 1,900 mm $\mathrm{yr}^{-1}$, and a tropical wet and dry climate in the Cerrado catchments, with a mean precipitation of ca. 1,700 $\mathrm{mm} \mathrm{yr}^{-1}$. More details regarding the climate, soils, morphology and hydrology of this region can be found in Lamparter et al. (2018), and Guzha et al. (2015) and in Nóbrega et al. (2017) for the Amazonian and Cerrado catchments, respectively. For clarity and to simultaneously compare the contrasting catchments within their respective biomes, we use the term native vegetation catchments to refer to the AFOR and CCER catchments, and the term pasture catchments to refer to the APAS and CPAS catchments, whose main characteristics are shown in Table 6.1. We instrumented these catchments during the dry season of 2012 and continuously monitored them from October of 2012 until the September of 2014.

\subsection{Methods}

\subsubsection{Soil physical and chemical properties}

To support our findings related to CAN stream dynamics, we used evidence from soil chemical and textural analyses. We collected disturbed soil samples from the topsoil (0-10 cm soil depth), from 6 to 8 approximately equally spaced points along a topographic sequence of landscape positions from a gently sloping upper plateau, to a middle slope and a low-gradient valley bottom on the basis of digital elevation models (DEMs) derived from a topographic survey in each catchment. The topsoil of these catchments was chosen because it has a strong synergy with the surface waters and it is the soil layer under most direct influence of the LULC change (Lamparter et al., 2018).

The topographic survey conducted in the Cerrado catchments is described in detail in Nóbrega et al. (2017); the described procedure was also used for the Amazonian catchments. We analyzed these soil samples to determine $\mathrm{pH}$, total carbon (TC), total nitrogen $(\mathrm{TN})$, aluminum $(\mathrm{Al})$, calcium $(\mathrm{Ca})$, iron $(\mathrm{Fe})$, potassium $(\mathrm{K})$, magnesium $(\mathrm{Mg})$, 
sodium $(\mathrm{Na})$, phosphorus $(\mathrm{P})$, sulfur $(\mathrm{S})$ and particle size distribution. The particle size distribution was measured using the Köhn pipette method (DIN ISO 11277:2002-08, 2002). $\mathrm{pH}$ was measured using the potentiometric method (inoLAB ${ }^{\circledR} \mathrm{pH}$ Level 2 , Wissenschaftlich-Technische Werkstätten $\mathrm{GmbH}$ ). TC and TN were quantified using an elemental analysis method (TruSpec ${ }^{\circledR} \mathrm{CHN}$, LECO Instrumente $\mathrm{GmbH}$ ). For chemical analysis, a total digestion of $100-150 \mathrm{mg}$ of soil was created with $\mathrm{HClO}_{4}, \mathrm{HF}$ and $\mathrm{HNO}_{3}$ in $30-\mathrm{mL}$ polytetrafluoroethylene (PTFE) vessels (Pressure Digestion System DAS 30, PicoTrace $\mathrm{GmbH}$ ), and chemical concentrations were determined using inductively coupled plasma atomic emission spectroscopy (ICP-OES, Optima $4300^{\mathrm{TM}}$ DV for the Cerrado catchments and ICP-OES Optima $5300^{\mathrm{TM}}$ for the Amazonian catchments, PerkinElmer, Germany). Chemical analyses of soils from the Amazonian catchments were conducted at the Laboratory of the Department of Plant Ecology and Ecosystems Research and those of the Cerrado catchments were conducted at the Laboratory of the Department of Landscape Ecology, both at the University of Goettingen, Germany.

Table 6.1 Main characteristics of the catchments.

\begin{tabular}{|c|c|c|c|c|}
\hline \multirow{4}{*}{\begin{tabular}{|c|} 
Biome \\
Area (ha)
\end{tabular}} & \multicolumn{2}{|c|}{ Amazonian catchments } & \multicolumn{2}{|c|}{ Cerrado catchments } \\
\hline & AFOR & APAS & CCER & CPAS \\
\hline & \multicolumn{2}{|c|}{ Amazon } & \multicolumn{2}{|c|}{ Cerrado } \\
\hline & 93.4 & 23.1 & 77.8 & 58.4 \\
\hline $\begin{array}{l}\text { Mean precipitation } \\
\left(\mathrm{mm} \mathrm{yr}^{-1}\right)\end{array}$ & \multicolumn{2}{|c|}{1,900} & \multicolumn{2}{|c|}{1,700} \\
\hline Wet season & \multicolumn{2}{|c|}{ Nov-May } & \multicolumn{2}{|c|}{ Oct-Apr } \\
\hline Farm property & \multicolumn{2}{|c|}{ Paraíso farm } & $\begin{array}{l}\text { Rancho do Sol } \\
\text { farm }\end{array}$ & Gianetta farm \\
\hline Coordinates & $\begin{array}{l}7.032^{\circ} \mathrm{S} \\
55.363^{\circ} \mathrm{W}\end{array}$ & $\begin{array}{l}7.023^{\circ} \mathrm{S} \\
55.375^{\circ} \mathrm{W}\end{array}$ & $\begin{array}{l}15.797^{\circ} \mathrm{S} \\
55.332^{\circ} \mathrm{W}\end{array}$ & $\begin{array}{l}15.805^{\circ} \mathrm{S} \\
55.336^{\circ} \mathrm{W}\end{array}$ \\
\hline $\begin{array}{l}\text { Soil classification } \\
\text { (IUSS Working Group } \\
\text { WRB, 2015, and Soil } \\
\text { Survey Staff, 2014) }\end{array}$ & \multicolumn{2}{|c|}{ Lixisols, Oxisols } & \multicolumn{2}{|c|}{ Arenosols, Entisols Quartzipsamments } \\
\hline $\begin{array}{c}\text { Predominant land } \\
\text { cover }\end{array}$ & Rainforest & Pasture & $\begin{array}{l}\text { Cerrado sensu } \\
\text { stricto }\end{array}$ & Pasture \\
\hline Aspect & \multicolumn{4}{|c|}{ E-W } \\
\hline Average slope (\%) & 23.6 & 7.5 & 8.4 & 7.7 \\
\hline Average elevation (m) & 292.4 & 223.0 & 811.1 & 817.8 \\
\hline
\end{tabular}

\subsubsection{Water sampling design and analysis}

An automatic water sampler $\left(\mathrm{BL} 2000^{\circledR}\right.$, Hach-Lange $\left.\mathrm{GmbH}\right)$ was installed at the outlet of each catchment to collect stream water ca. $20 \mathrm{~cm}$ below the water surface and 2-4 
$\mathrm{m}$ upstream from the catchment weir. The sampling procedure was simultaneously based on both time intervals and water-level variations to characterize the streamflow hydrochemistry during baseflow- and stormflow-prevailing conditions, respectively. The time sampling routine was based on filling a 1-L sample bottle over 1-3 days using an extraction of $200 \mathrm{~mL}$ from the stream at equal intervals. The stormflow sampling was determined suing a subhourly routine activated by water-level increase and detected by a pressure bell switch (FD-01, Profimess $\mathrm{GmbH}$ ). The pressure bell switches and the automatic samplers were calibrated throughout the year according to the water-level variation to maximize the coverage of the catchment stormflows, which considered the time of every sampling procedure and its respective hydrograph.

The samples from the Cerrado catchments were transported to the Ecofisiologia Vegetal Laboratory (EVL) at the Federal University of Mato Grosso (UFMT) in Cuiabá, Mato Grosso. The samples from the Amazonian catchments were also brought to this laboratory with prior preparation at a field facility ca. $5 \mathrm{~km}$ from the catchments and stored in light-free freezers until their transportation to the EVL. Transport of all water samples to the EVL was made using light-free coolers packed with ice. After transportation, the water in each bottle was used to fill two $50-\mathrm{mL}$ aliquots in highdensity polyethylene bottles prewashed with deionized water. One aliquot was used for the analysis of TC, total organic carbon (TOC), total inorganic carbon (TIC) and $\mathrm{TN}$, and the other was filtered with pre-ashed glass fiber filters $(0.7-\mu \mathrm{m}$ nominal pore size, Whatman GF/F) prewashed with $20 \mathrm{~mL}$ of water sample for the remaining analyses. The samples were then frozen and shipped in Styrofoam coolers for analysis at the Laboratory of the Department of Landscape Ecology, University of Goettingen, Germany (total travel time of ca. $22 \mathrm{~h}$ ).

TC, TIC, TOC, total dissolved carbon (DC), dissolved inorganic carbon (DIC) and DOC contents were determined using high-temperature catalytic oxidation (TC-Analyzer, DIMATOC $100(\mathrm{R})$, Dimatec $\mathrm{GmbH})$. TN and $\mathrm{DN}$ were quantified using the chemiluminescence detection method (DIMA_N module (CLD), Dimatec $\mathrm{GmbH}$ ). Fluorine $(\mathrm{F})$, chlorine $(\mathrm{Cl})$, nitrate $\left(\mathrm{NO}_{3}\right)$ and sulfate $\left(\mathrm{SO}_{4}\right)$ concentrations were determined using ion chromatography (761 Compact IC, Metrohm, Switzerland). Dissolved $\mathrm{Ca}, \mathrm{Fe}, \mathrm{K}, \mathrm{Mg}, \mathrm{Na}, \mathrm{P}$ and $\mathrm{S}$ concentrations were quantified using atomic spectroscopy (ICP-OES, Optima 4300 TM DV, PerkinElmer). Prior to the analyses of 
the dissolved solutes, the water samples were filtered through membrane filters $(0.45$ $\mu \mathrm{m}$ nominal pore size, cellulose acetate, Sartorius Stedim Biotech $\mathrm{GmbH}$ ). These filters were prewashed with ultrapure water and transferred to high density polyethylene (HDPE) bottles that were prewashed with nitric acid solution (2.6\% $\mathrm{HNO}_{3}$ ) and rinsed with ultrapure water.

For quality control, during the entire study period, approximately $20 \%$ of the water samples were analyzed for DOC within 12 hours after collection using a UV-Vis spectrometric device (spectro::lyser ${ }^{\mathrm{TM}}$ UV-Vis, s::can Messtechnik GmbH) to crosscheck with the final DOC results. This comparison indicated a linear correlation $(r=$ .96, $n=200, p<.001$, Pearson's correlation), which is considered adequate because of the insignificant differences in DOC estimation by the spectrometric device calibration (Bass et al., 2011; Avagyan et al., 2014). Additionally, a 1-L water sample was manually collected in an automatic sampler bottle and kept in a separate automatic water sampler unit at the EVL to check DOC fluctuations resulting from the storage of the samples in this instrument. This water sample was analyzed using the spectrometric device up to 8 days after sampling, which was the average time interval of the field trips for sample collection. This procedure was conducted during the first wet season (January-May of 2013) and did not indicate any significant changes in the DOC concentrations.

\subsubsection{Streamflow and CAN output fluxes}

At the outlet of each catchment, an adjustable weir was installed. During the rainy season, the weirs were rectangular, whereas a v-notch contraction section was inserted during the dry season. A multiparameter probe (DS 5X, OTT) was installed 2-4 m upstream of each catchment's weir to obtain data on water level at 10 or 15min intervals. To quantify catchment discharge (flow rate), we used the standard flow equation (Eq. (1)) based on the Bernoulli equation for the rectangular weir, and the Kindsvater-Shen equation (Eq. (2)) together with calibration adjustment functions (Eqs. (3) and (4)) for the v-notch weir (Shen, 1981), as follows:

$Q=\frac{2}{3} C_{d R} b \sqrt{2 g} h^{\frac{3}{2}}$

$Q=\frac{8}{15} C_{e} \sqrt{2 g} \tan \left(\frac{\theta}{2}\right) h_{e^{\frac{5}{2}}}$ 
$K_{h}=0.001[\theta(1.395 \theta-4.296)+4.135]$,

$C_{e}=\theta(0.02286 \theta-0.05734)+0.6115$,

where $Q$ is the discharge over the weir $\left(\mathrm{m}^{3} \mathrm{~s}^{-1}\right)$; $\mathrm{CdR}$ and $\mathrm{Ce}$ are the effective dimensionless discharge coefficients for the rectangular and v-notch weirs, respectively; $b$ is the weir length $(m) ; \theta$ is the angle of the $v$-notch (radians); $h$ is the upstream head above the crest of the weir $(m)$; $h_{e}$ is the effective head $\left(h+K_{h}\right)$; and $\mathrm{K}_{\mathrm{h}}$ is the head-adjustment factor. For the Amazonian catchments, we adopted a $\mathrm{C}_{\mathrm{dR}}$ of 0.62 based on the geometric characteristics of the weirs (Kindsvater and Carter, 1957). For the Cerrado catchments, we conducted discharge calibration measurements using an acoustic digital current meter (ADC, OTT) and estimated $C_{d R}$ values of 0.74 for the CCER catchment and 0.65 for the APAS catchment.

We classified the streamflow as base streamflow $\left(\mathrm{S}_{\mathrm{b}}\right)$ and storm streamflow $\left(\mathrm{S}_{\mathrm{s}}\right)$, which represent the total stream discharge during baseflow- and stormflow-prevailing conditions, respectively. $S_{s}$ was computed as the flow change in response to event precipitation and ending at the point separating the stormflow components, i.e. the surface and subsurface stormflow, from the baseflow recession. These flows were determined using a recursive digital filter (Eckhardt, 2005) implemented in the Web GIS-based Hydrograph Analysis Tool (WHAT) for baseflow separation (Lim et al., $2005,2010)$. Using this information, we calculated the ratio of $S_{s}$ to total streamflow $\left(\mathrm{S}_{\mathrm{t}}\right)$ discharge.

The annual CAN stream output fluxes for each catchment were calculated multiplying the annual mean CAN concentration by the respective annual $S_{b}$ and $S_{s}$ volumes (Eqs. 5 and 6) as follows:

$$
\begin{aligned}
& F_{T S_{b}}=\frac{C_{S_{b}} \times V_{S_{b}}}{A \times 10^{6}}, \\
& F_{T S_{S}}=\frac{C_{S s} \times V_{S_{S}}}{A \times 10^{6}},
\end{aligned}
$$

where $\mathrm{F}_{\mathrm{TSb}}$ and $\mathrm{F}_{\mathrm{TSs}}$ are, respectively, the annual CAN output fluxes of $\mathrm{S}_{\mathrm{b}}$ and $\mathrm{S}_{\mathrm{s}}(\mathrm{kg}$ $\left.\mathrm{ha}^{-1} \mathrm{yr}^{-1}\right)$; $\mathrm{Csb}_{\mathrm{sb}}$ is the mean CAN concentration in $\mathrm{Sb}_{\mathrm{b}}\left(\mathrm{mg} \mathrm{L}^{-1}\right)$; $\mathrm{Css}_{\mathrm{ss}}$ is the volume-weighted mean CAN concentration obtained using Eq. $7\left(\mathrm{mg} \mathrm{L}^{-1}\right) ; \mathrm{V}_{\mathrm{sb}}$ and $\mathrm{V}_{\mathrm{Ss}}$ are the mean annual $S_{b}$ and $S_{s}$ discharges $\left(L y^{-1}\right)$, respectively; and $A$ is the catchment area (ha). 
$C_{S S}=\frac{\sum_{j=1}^{m}\left(\sum_{i=1}^{n} \frac{c_{S_{S(i)}}}{n}\right) \times V j}{\sum_{j=1}^{m} V j}$,

where $\mathrm{Css}_{\mathrm{s}(\mathrm{i})}$ is the CAN concentration per $\mathrm{S}_{\mathrm{s}}$ event interval $i$ for the number of event intervals $n\left(\mathrm{mg} \mathrm{L}^{-1}\right)$ and $V_{j}$ is the volume per event $j$ for the number of $S_{s}$ events $m(L)$.

\subsubsection{Statistical analysis}

We used principal component analysis (PCA) to identify the most representative hydrochemical parameters causing most of the total variance in $S_{b}$ and $S_{s}$. PCA is commonly used to identify the variables that contain the most information and to provide future data collection criteria in ecological studies (King and Jackson, 1999; Zhang et al., 2009). It is useful for the identification of important surface water-quality parameters (Ouyang, 2005; Zeinalzadeh and Rezaei, 2017).

We conducted PCAs separately for each biome (Amazon and Cerrado) and flow condition $\left(\mathrm{S}_{\mathrm{b}}\right.$ and $\mathrm{S}_{\mathrm{s}}$ ) in order to avoid the dominance of the PCA by the data variance of only one specific region or streamflow condition. We used the Kaiser-Meyer-Olkin (KMO) test (Kaiser, 1974) as a measure of quality control in the PCAs. The KMO test measures the sampling adequacy of each variable for the complete analysis. We only considered CAN parameters with individual KMO values greater than the bare minimum of .5; therefore we repeated the PCAs, excluding the unacceptable CAN parameters from the analyses, until we obtained acceptable individual KMO results. We applied the orthogonal rotation varimax with Kaiser normalization to the PCAs to maximize the dispersion of loadings within the factors and considered the results with the most significant components (eigenvalues $>1$ ).

We used the Kolmogorov-Smirnov test of normality for each dataset to determine the adequate statistical test, i.e., parametric or nonparametric, for comparison of catchments within the same biome. We used the two-sample t-test to compare the soil chemistry and the Mann-Whitney (MW) U-test to compare the CAN concentrations by means of sample ranks to determine whether $S_{b}$ and $S_{s}$ were significantly different between the native vegetation and pasture catchments. Additionally to the MW test, we used Mood's median test, given its robustness for outliers to detect differences in the median. We used the language and environment R (R Core Team, 2017) and the significance threshold at .05 for all statistical analyses. 


\subsection{Results}

\subsubsection{Soil physical and chemical properties}

The soils exhibited textural similarities within each pair of catchments, with mostly sandy clay loams in the Amazonian and loamy sand textures in the Cerrado catchments (Table 6.2). The soil pH was between 10 to $25 \%$ higher in the pasture catchments, being significantly different $(p<.01)$ between the CCER and CPAS catchments. The soils from all catchments have a high content of $\mathrm{Al}$ and $\mathrm{Fe}$ and low nutrient contents (Table 2). K, Mg and Mn contents exhibited significant differences ( $p$ $<.05$ ) between the Amazonian catchments, with higher Mn content in the AFOR than that of the APAS catchment. In the Cerrado catchments, Ca was the only element to exhibit significant differences $(p<.01)$ between the CCER $\left(0.03 \mathrm{~g} \mathrm{~kg}^{-1}\right)$ and CPAS catchments $\left(0.18 \mathrm{~g} \mathrm{~kg}^{-1}\right)$.

Figure 6.2 shows the soil chemical results. The soils from all catchments have a high content of $\mathrm{Al}$ and $\mathrm{Fe}$, a characteristic often found in Amazon soils (Quesada et al., 2011; Dos Santos and Alleoni, 2013) and Cerrado (Buol, 2009). Further, we found low nutrient contents in the soils of all catchments. The $\mathrm{K}, \mathrm{Mg}$, and $\mathrm{Mn}$ contents exhibited significant differences $(p<.05)$ among the Amazonian catchments, with higher $\mathrm{Mn}$ content in the AFOR than in APAS catchment. In the Cerrado catchments, Ca was the only element to exhibit significant differences $(p<.01)$ between the CCER $\left(0.03 \mathrm{~g} \mathrm{~kg}^{-}\right.$ ${ }^{1}$ ) and CPAS catchments $\left(0.18 \mathrm{~g} \mathrm{~kg}^{-1}\right)$.

Table 6.2 Mean, one standard deviation and $\mathrm{n}$ of soil physical properties, and $\mathrm{C}$ and $\mathrm{N}$ contents.

\begin{tabular}{ccccc}
\hline \multirow{2}{*}{$\begin{array}{c}\text { Soil } \\
\text { attributes }\end{array}$} & \multicolumn{2}{c}{ Amazonian catchments } & \multicolumn{2}{c}{ Cerrado catchments } \\
\cline { 2 - 5 } & AFOR & APAS & CCER & CPAS \\
\hline Sand (\%) & $67.2 \pm 6.0(8)$ & $57.6 \pm 6.4(8)$ & $81.1 \pm 20.5(6)$ & $93.3 \pm 1.0(8)$ \\
\hline Silt (\%) & $9.1 \pm 3.9(8)$ & $22.8 \pm 6.0(8)$ & $6.1 \pm 7.3(6)$ & $1.5 \pm 0.4(8)$ \\
\hline Clay (\%) & $23.7 \pm 6.1(8)$ & $19.6 \pm 5.5(8)$ & $14.0 \pm 13.4(6)$ & $5.2 \pm 0.7(8)$ \\
\hline pH & $5.7 \pm 0.3(3)$ & $6.4 \pm 0.7(3)$ & $3.6 \pm 0.3(6)$ & $4.4 \pm 0.5(8)$ \\
\hline $\mathbf{C ~ ( \% ) ~}$ & $3.19 \pm 2.54(5)$ & $1.47 \pm 0.45(6)$ & $3.41 \pm 3.88(6)$ & $1.33 \pm 1.01(8)$ \\
\hline $\mathbf{N}(\%)$ & $0.27 \pm 0.22(5)$ & $0.12 \pm 0.04(6)$ & $0.18 \pm 0.20(6)$ & $0.07 \pm 0.05(8)$ \\
\hline C:N ratio & $11.9 \pm 1.8$ & $11.8 \pm 0.5$ & $17.9 \pm 2.4$ & $18.3 \pm 3.3$ \\
\hline
\end{tabular}




\subsubsection{Hydrochemistry results}

TOC, DOC, $\mathrm{K}$ and $\mathrm{NO}_{3}$ exhibited the highest mean concentrations $\left(>1 \mathrm{mg} \mathrm{L}^{-1}\right)$ in the Amazonian catchments under both flow conditions. For these catchments, our results indicate low mean streamflow concentrations for $\mathrm{Cl}_{1} \mathrm{SO}_{4}, \mathrm{Na}, \mathrm{Ca}$ and $\mathrm{Mg}(<0.4 \mathrm{mg} \mathrm{L}-$ $\left.{ }^{1}\right)$. In the Cerrado catchments, $\mathrm{TOC}, \mathrm{DOC}, \mathrm{NO}_{3}$ and $\mathrm{Ca}$ showed the highest mean concentrations. Other elements, such as $\mathrm{Mg}$ and $\mathrm{Na}$, exhibited relatively low concentrations in the CCER catchment. Fe, F, P, S and $\mathrm{SO}_{4}$ had the lowest concentrations in all catchments, with most values less than the limit of detection (Appendix 1 and Appendix 2).

The varimax rotation applied to the PCA on the water quality parameters exhibited individual $\mathrm{KMO}$ values greater than .5 (Table 6.3). The overall $\mathrm{KMO}$ was .70 for $\mathrm{S}_{\mathrm{b}}$ and .63 for the $S_{s}$ PCAs in the Amazonian catchments, and .68 for both the $S_{b}$ and $S_{s}$ PCAs in the Cerrado catchments, which are acceptable values of sampling adequacy for PCA (Kaiser, 1974). Bartlett's test of sphericity for the parameters indicated that correlations between items were sufficiently great for PCA $(p<.001)$. Kaiser's criterion of eigenvalues greater than 1 was met by two components in the $S_{b}$ PCAs and by three components in the stormflow PCAs for the Amazonian and Cerrado catchments. In combination, these components explained $80 \%$ and $86 \%$ of the variance in the $S_{b}$ and $S_{s}$ values in the Amazonian catchments, and $83 \%$ and $88 \%$ of the variance in the $S_{b}$ and $S_{s}$ values in the Cerrado catchments, respectively. Some parameters, such as TC, TOC, DC and DOC, cluster in the same components in all PCAs with high factor loadings.

In all of the PCAs, the first two components account for more than $60 \%$ of the total variance (Fig.6. 2). For the Amazonian catchments, the first component of the $S_{b}$ PCA (Fig 6.2a) was mostly correlated with nitrogen and organic carbon, which showed the highest standard deviations. The items that cluster in the second component represent the inorganic carbon and cations ( $\mathrm{Ca}$ and $\mathrm{K}$ ). The main difference between the $\mathrm{S}_{\mathrm{b}}$ and $\mathrm{S}_{\mathrm{s}}$ PCAs (Fig. 6.2b) is the clustering of $\mathrm{NO}_{3}, \mathrm{TN}$ and $\mathrm{DN}$ in the third component of the $S_{s}$ PCA, suggesting that during stormflow events, nitrogen fluxes have a distinct dynamic from that of the other nutrients. For the Cerrado catchments, the first component of the Sb PCA (Fig. 6.2c) groups carbon and $\mathrm{Ca}$, and the second 
component groups $\mathrm{TN}, \mathrm{DN}$ and $\mathrm{NO}_{3}$. This is the only PCA where the organic and inorganic carbon compounds cluster in the same component. The Ss PCA (Fig. 6.2d) shows that the first component groups $\mathrm{DOC}$ with $\mathrm{DN}, \mathrm{NO}_{3}$ and $\mathrm{K}$, and the second component shows a high factor loading grouping of TIC, DIC and $\mathrm{Ca}$. The third component of this PCA groups TC, TOC and TN. This is the only PCA where TOC does not group together with $\mathrm{DOC}$, which indicates the importance of particulate organic carbon $(\mathrm{POC})$ in these catchments. We did not directly measure $\mathrm{POC}$ in our study, but the differences between TOC and DOC, which could be interpreted as POC (Zhou et al., 2013), were the highest in the Cerrado catchments, representing an average of $19 \%$ of the TOC.

Based on the results of the PCAs, we compared TOC, DOC, TIC, DIC, TN and DN (Fig. 6.3), and $\mathrm{NO}_{3}, \mathrm{Ca}$ and $\mathrm{K}$ (Fig. 6.4). With the exception of higher TOC in the APAS catchment, $S_{s}$ carbon concentrations between the Amazonian catchments did not exhibit significant differences. In the Cerrado catchments, the highest differences were found in $S_{s}$, with higher TOC and DOC concentrations in the CPAS catchment compared to those of the CCER (Fig. 6.3a-b). For DIC, the differences in concentration between the Amazonian catchments in $S_{b}$ and between the Cerrado catchments in $\mathrm{S}_{\mathrm{s}}$ (Fig. 6.3c-d) were significant.

Except for DN in $\mathrm{Sb}_{\mathrm{b}}$ of the Amazonian catchments, the pasture catchments exhibited higher TN and DN concentrations than those of the native vegetation catchments. The differences in $\mathrm{NO}_{3}$ were significant between the Cerrado catchments, with higher concentrations in the CPAS catchment, whereas there was no significant difference in the Amazonian catchments (Fig. 6.4a). Differences in Ca concentrations (Fig. 6.4b) were significant in the catchments of both biomes, but not for the same flow conditions. While the difference in Ca was significant only in $\mathrm{S}_{b}$ of the Amazonian catchments, this was only observed in $S_{s}$ of the Cerrado catchments. There were significantly higher $\mathrm{K}$ concentrations in both $\mathrm{S}_{\mathrm{b}}$ and $\mathrm{S}_{\mathrm{s}}$ for the pasture catchments (Fig. 6.4c).

\subsubsection{Hydrological and CAN output fluxes}

The Amazonian catchments exhibited the greater annual average stream discharge with $23.2 \mathrm{~L} \mathrm{~s}^{-1}$ for the AFOR catchment and $18.3 \mathrm{~L} \mathrm{~s}^{-1}$ for the APAS catchment, whereas the stream discharge for the Cerrado catchments were $11.6 \mathrm{~L} \mathrm{~s}^{-1}$ for the 
CCER catchment and 13.4 $\mathrm{L} \mathrm{s}^{-1}$ for the CPAS catchment. The average stream discharge during stormflow events were $94.2 \mathrm{~L} \mathrm{~s}^{-1}$ for the AFOR catchment, 89.5 for the APAS catchment, $11.6 \mathrm{~L} \mathrm{~s}^{-1}$ for the CCER catchment and $30.9 \mathrm{~L} \mathrm{~s}^{-1}$ for the CPAS catchment.

In the Amazonian catchments, TOC output fluxes were between 35 and $135 \mathrm{~kg} \mathrm{ha}^{-1}$ $\mathrm{yr}^{-1}$, and $\mathrm{K}$ and $\mathrm{NO}_{3}$ values ranged from 8 to $60 \mathrm{~kg} \mathrm{ha}^{-1} \mathrm{yr}^{-1}$ (Fig. 6.5). In the Cerrado catchments, $\mathrm{TOC}, \mathrm{Ca}$ and $\mathrm{NO}_{3}$ had total output fluxes between 2 and $12 \mathrm{~kg} \mathrm{ha}^{-1} \mathrm{yr}^{-1}$, and DIC and DN had output fluxes less than $2 \mathrm{~kg} \mathrm{ha}^{-1} \mathrm{yr}^{-1}$. Although the two biomes show different magnitudes of CAN fluxes with higher fluxes in the Amazonian catchments, the $S_{b}$ CAN fluxes were higher than those of the $S_{s}$ in all catchments. Furthermore, the fluxes in the pasture catchments were generally higher compared to those of the native vegetation catchments.

Table 6.3 Correlations between variables and components after varimax rotation.

\begin{tabular}{|c|c|c|c|c|c|c|}
\hline & \multicolumn{3}{|c|}{ Amazonian catchments } & \multicolumn{3}{|c|}{ Cerrado catchments } \\
\hline & $\mathrm{S}_{\mathrm{b}}$ & \multicolumn{2}{|r|}{$\mathrm{S}_{\mathrm{s}}$} & $\mathrm{S}_{\mathrm{b}}$ & \multicolumn{2}{|l|}{$\mathrm{S}_{\mathrm{s}}$} \\
\hline & $\mathrm{C} 1 \quad \mathrm{C} 2$ & C1 & C2 $\mathrm{C} 3$ & $\begin{array}{ll}\text { C1 } & \text { C2 }\end{array}$ & $\begin{array}{ll}\text { C1 } & \text { C2 }\end{array}$ & C3 \\
\hline TC & $\begin{array}{ll}.92 & .27\end{array}$ & .99 & $\begin{array}{ll}.07 & .07\end{array}$ & $\begin{array}{ll}.98 & -.02\end{array}$ & $\begin{array}{ll}.32 & .25\end{array}$ & .90 \\
\hline TIC & $\begin{array}{ll}.12 & .88\end{array}$ & .07 & $\begin{array}{ll}.95 & -.17\end{array}$ & $\begin{array}{ll}.94 & -.12\end{array}$ & $\begin{array}{ll}.00 & .99\end{array}$ & .05 \\
\hline TOC & $\begin{array}{ll}.95 & .05\end{array}$ & .99 & $.02 \quad .08$ & $.77 \quad .11$ & $.33 \quad .06$ & .92 \\
\hline TN & $\begin{array}{ll}.81 & .30\end{array}$ & .12 & $\begin{array}{ll}.10 & .92\end{array}$ & $\begin{array}{ll}.04 & .96\end{array}$ & $\begin{array}{ll}.49 & .01\end{array}$ & .75 \\
\hline $\mathrm{DC}$ & $\begin{array}{ll}.88 & .19\end{array}$ & .99 & $\begin{array}{ll}.12 & .01\end{array}$ & $\begin{array}{ll}.96 & -.24\end{array}$ & $\begin{array}{ll}.74 & .36\end{array}$ & .41 \\
\hline DIC & $\begin{array}{ll}.01 & .93\end{array}$ & .07 & $\begin{array}{ll}.95 & -.25\end{array}$ & $\begin{array}{ll}.94 & -.12\end{array}$ & $\begin{array}{ll}.01 & .99\end{array}$ & .07 \\
\hline DOC & $\begin{array}{ll}.91 & -.05\end{array}$ & 1.00 & $\begin{array}{ll}.07 & .03\end{array}$ & $\begin{array}{ll}.79 & -.35\end{array}$ & $\begin{array}{ll}.79 & .01\end{array}$ & .41 \\
\hline DN & $\begin{array}{ll}.85 & .19\end{array}$ & .09 & $-.14 \quad .95$ & $\begin{array}{ll}-.03 & .92\end{array}$ & $\begin{array}{ll}.77 & -.05\end{array}$ & .33 \\
\hline $\mathrm{NO}_{3}$ & - & -.12 & $\begin{array}{ll}.40 & .56\end{array}$ & $\begin{array}{ll}.16 & .74\end{array}$ & $\begin{array}{ll}.87 & .03\end{array}$ & .12 \\
\hline $\mathrm{Ca}$ & $\begin{array}{ll}.22 & .82 \\
\end{array}$ & $\begin{array}{l}.02 \\
\end{array}$ & $\begin{array}{ll}.92 & -.01 \\
\end{array}$ & $\begin{array}{ll}.93 & -.06\end{array}$ & $\begin{array}{ll}.12 & .97\end{array}$ & .13 \\
\hline $\mathrm{K}$ & $\begin{array}{ll}.20 & .79\end{array}$ & .17 & $\begin{array}{ll}.56 & .37\end{array}$ & - & $\begin{array}{ll}.87 & .05\end{array}$ & .29 \\
\hline Eigenvalue & $\begin{array}{ll}5.5 & 2.5\end{array}$ & 4.3 & $\begin{array}{ll}3.2 & 2.0\end{array}$ & $\begin{array}{ll}6.0 & 2.3\end{array}$ & $\begin{array}{ll}5.8 & 2.9\end{array}$ & 1.0 \\
\hline Variability (\%) & $48.2 \quad 31.7$ & 36.6 & 28.820 .9 & 57.725 .4 & $34.0 \quad 28.4$ & 25.4 \\
\hline
\end{tabular}


(a)

Amazon base streamflow

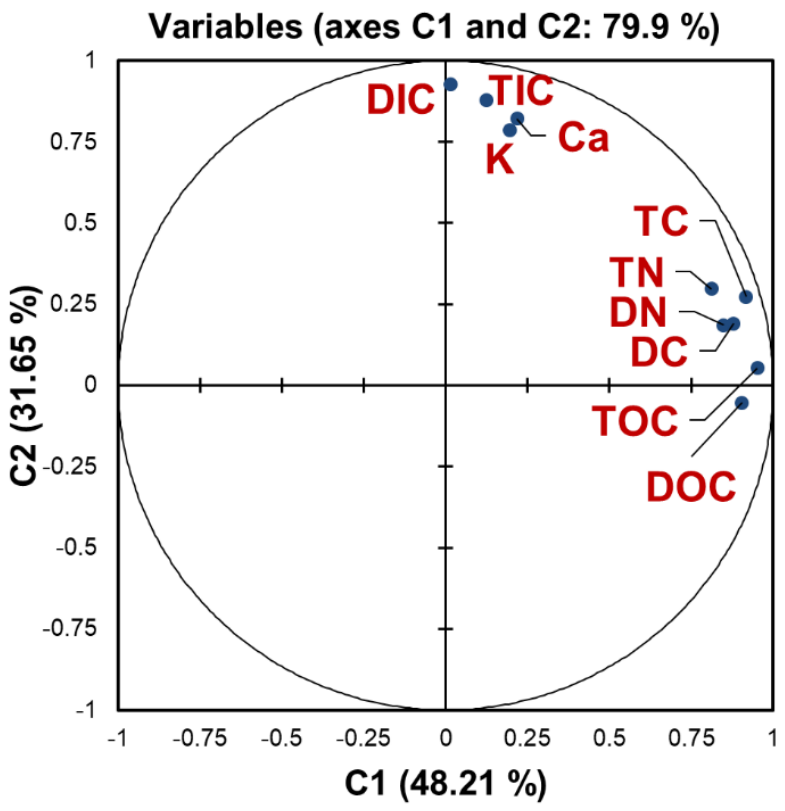

(c)

Cerrado base streamflow Variables (axes C1 and C2: 83.1\%)

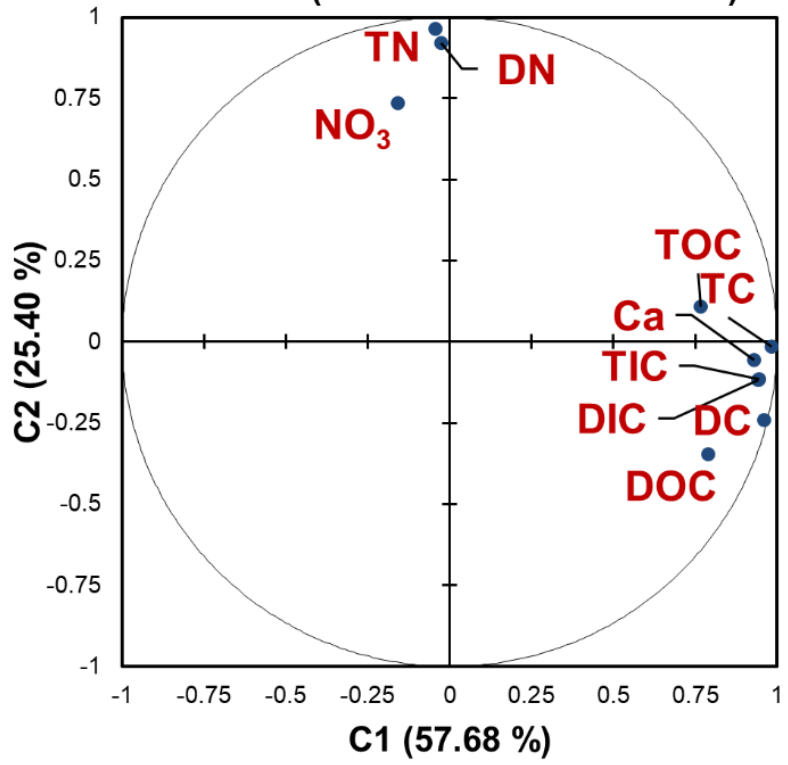

(b)

Amazon storm streamflow Variables (axes C1 and C2: 65.4 \%)

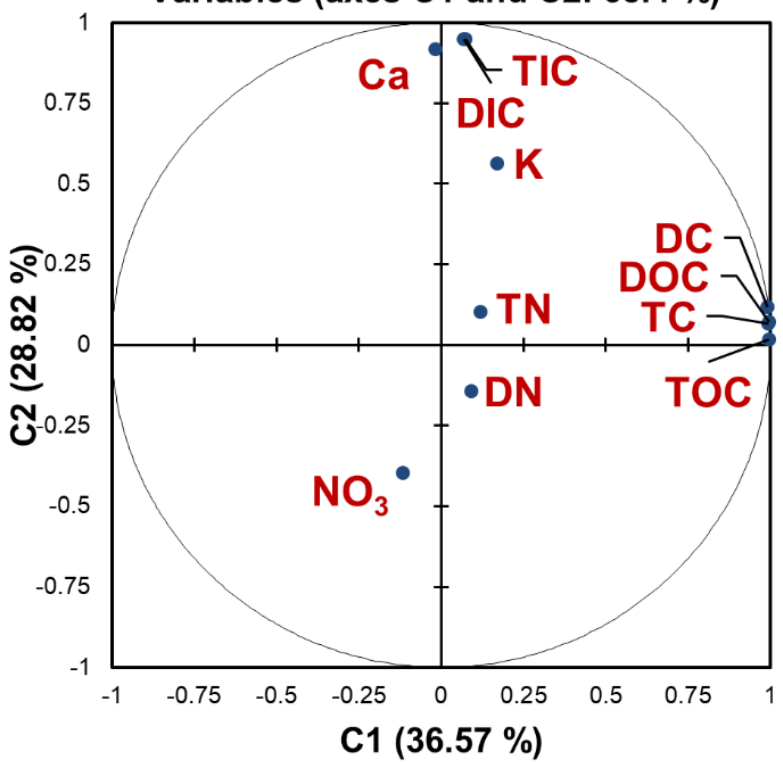

(d)

Cerrado storm streamflow Variables (axes C1 and C2: $62.4 \%$ )

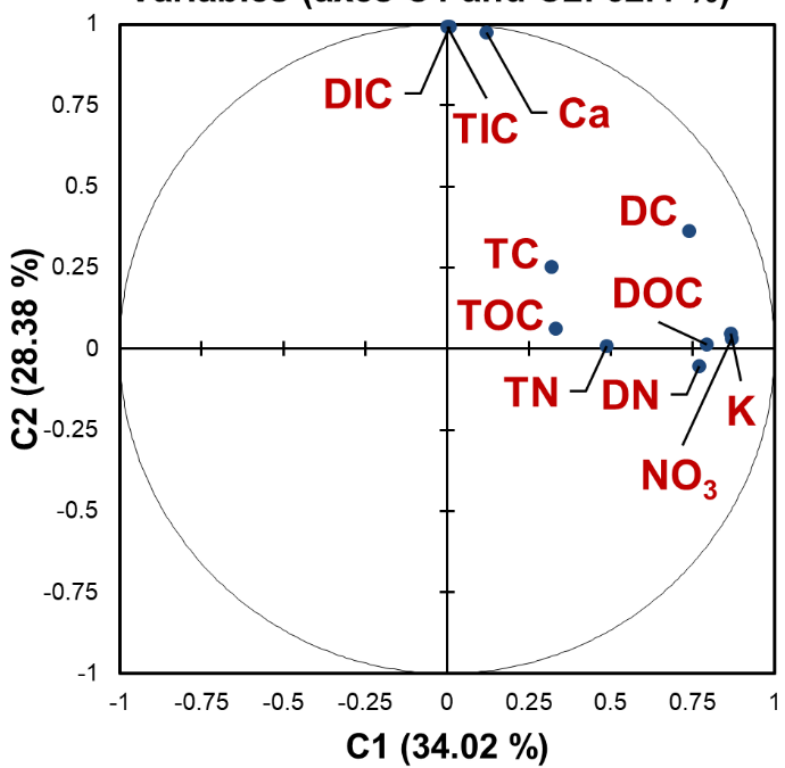

Figure 6.2 Biplots of the PCAs after varimax rotation for the first (C1) and second (C2) components of the: a) Amazon catchments base streamflow ( $\left.\mathrm{S}_{b}\right)$; b) Amazon catchments storm streamflow $\left(\mathrm{S}_{\mathrm{s}}\right)$; c) Cerrado catchments base streamflow $\left(\mathrm{S}_{\mathrm{b}}\right)$; and d) Cerrado storm strea streamflow $\left(\mathrm{S}_{\mathrm{s}}\right)$. 


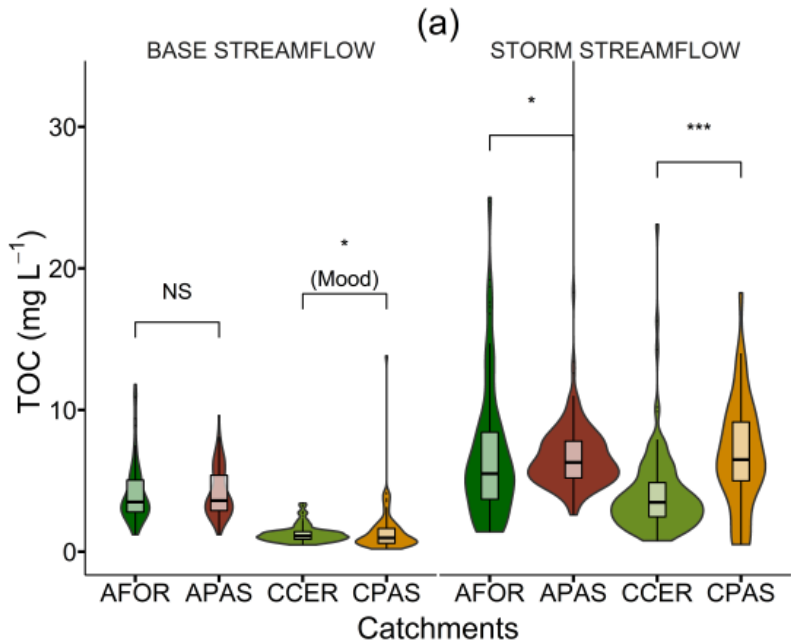

(c)

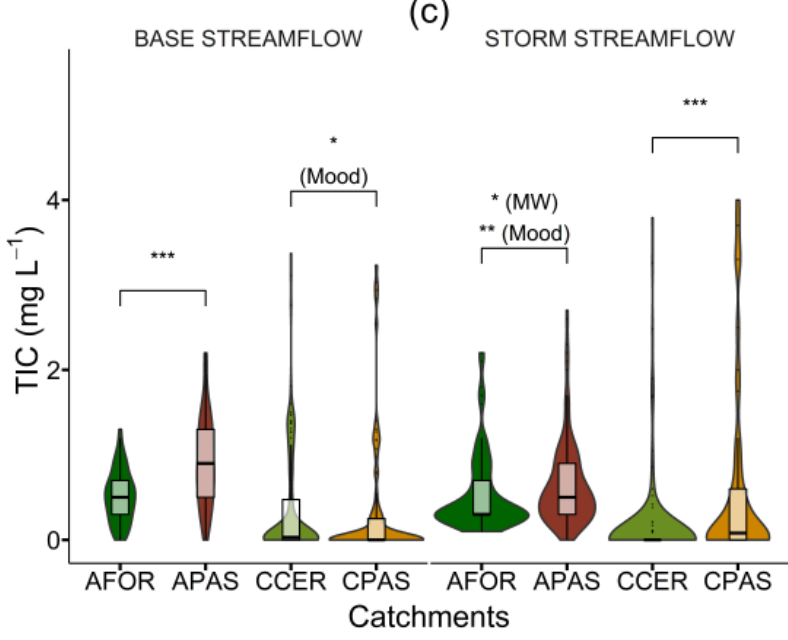

(e)

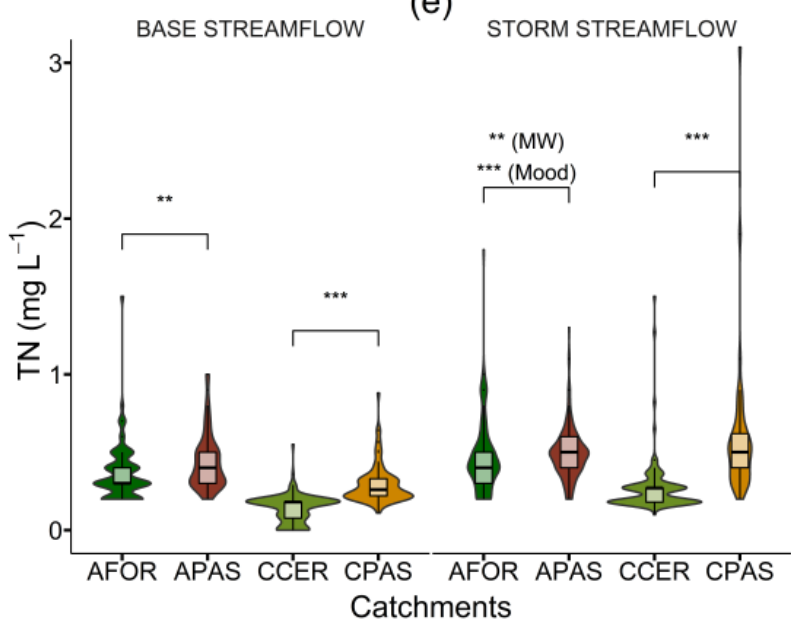

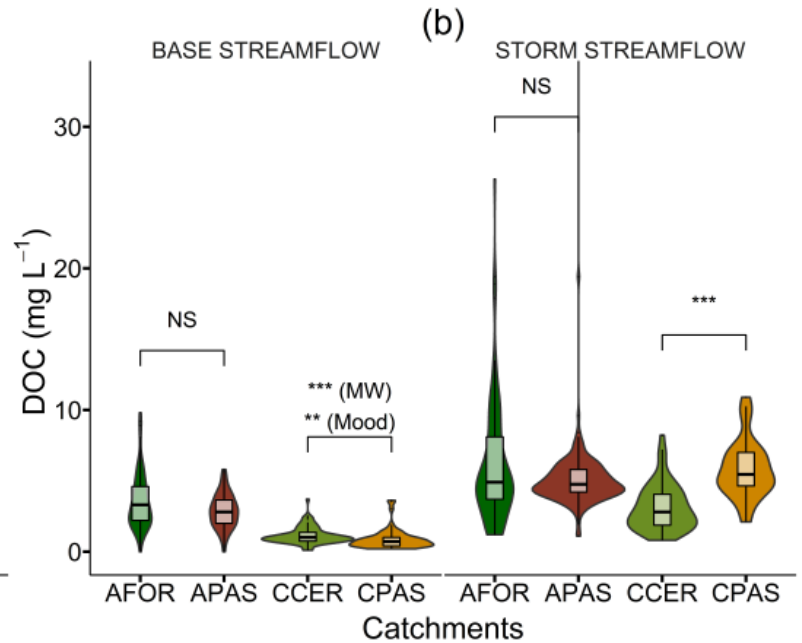

(d)

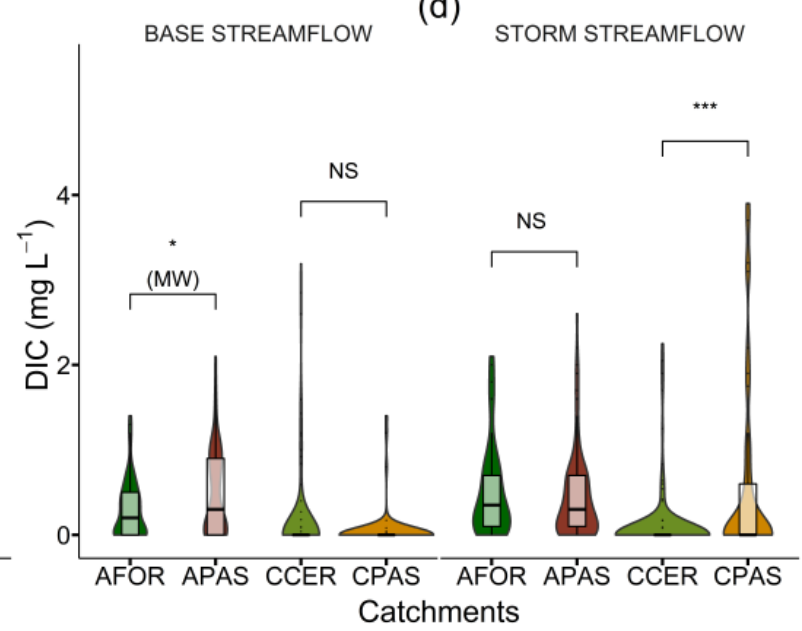

(f)

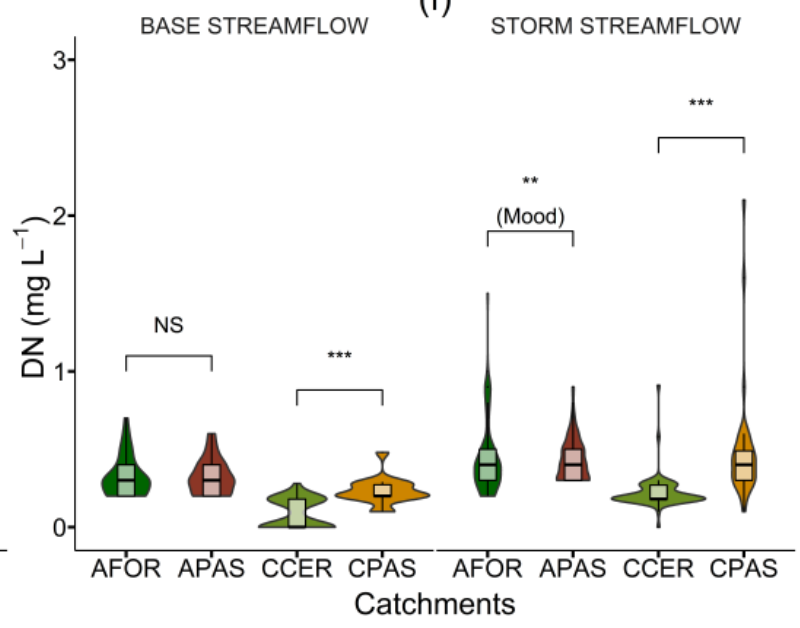

Figure 6.3 Boxplot and violin plots of non-flow weighted carbon and nitrogen concentrations in base streamflow and storm streamflow. The violin plots indicate the density of the sample distribution across the $y$-values. The $y$-axis was limited to exclude some outliers (only graphically) for better visualization of the results. NS stands for not significant and ${ }^{*},{ }^{* *}$ and ${ }^{* * *}$ indicate statistical significance at the $.05, .01$ and .001 probability levels, respectively. The significance of the results was based on the MW and Mood tests. When the test type is not indicated, the result is valid for both tests. 
(a)

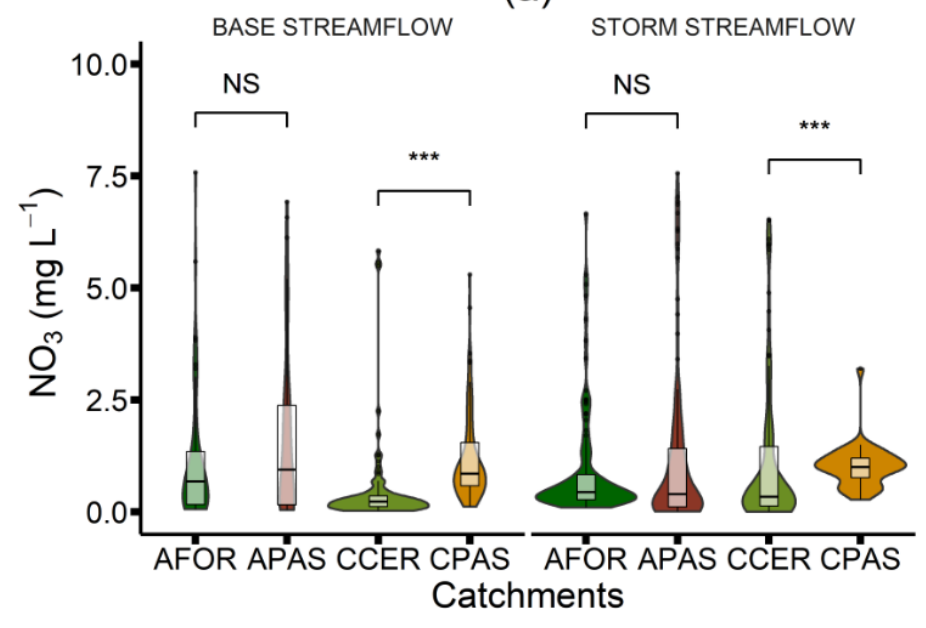

(b)

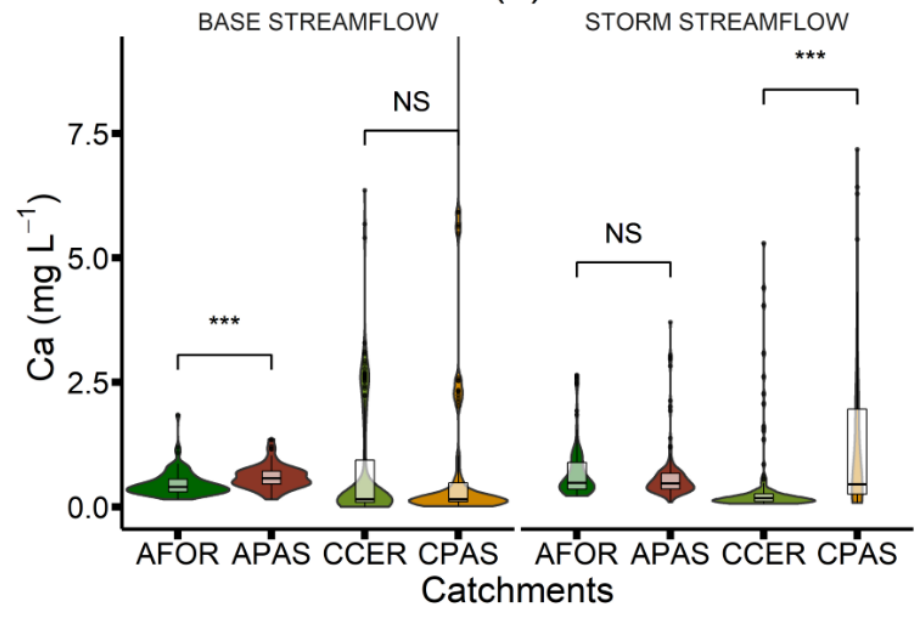

(c)

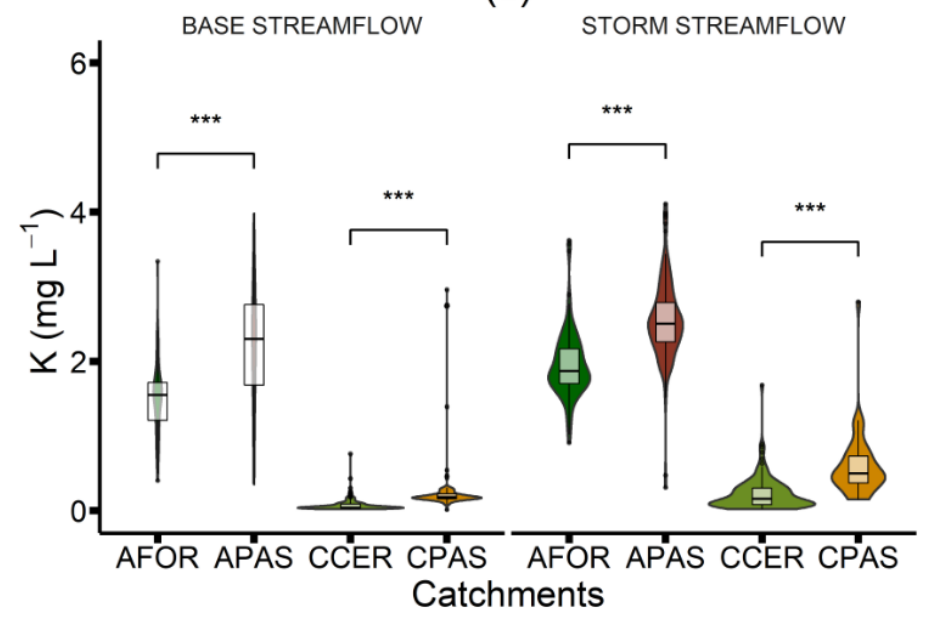

Figure 6.4 Boxplot and violin plots of $\mathrm{NO}_{3}, \mathrm{Ca}$ and $\mathrm{K}$ non-flow weighted concentrations in base streamflow and storm streamflow. The violin plots indicate the density of the sample distribution across the $y$-values. The $y$-axis was limited to exclude some outliers (only graphically) for better visualization of the results. NS stands for not significant and ${ }^{*},{ }^{* *}$ and ${ }^{* * *}$ indicate the statistical significance at the $.05, .01$ and .001 probability levels, respectively. The significance results were based on the MW and Mood tests. When the test type is not indicated, the result is valid for both tests. 


\subsection{Discussion}

\subsubsection{Stream hydrochemistry}

Our results showed significantly higher CAN concentrations in the pasture catchments compared to those of the native vegetation catchments, especially for TIC, TN and K. Some other macronutrients ( $\mathrm{Mg}, \mathrm{P}$ and $\mathrm{S}$ ) and micronutrients ( $\mathrm{F}, \mathrm{Cl}, \mathrm{Fe}$ and $\mathrm{Na}$ ) exhibited concentrations of $<1 \mathrm{mg} \mathrm{L}^{-1}$ in all of the studied catchments. Our DOC results for the Amazonian streams are in accordance with other studies of $S_{b}$ of major tributaries of the Amazon River (Moreira-Turcq et al., 2003; Tardy et al., 2005) and in $\mathrm{S}_{\mathrm{s}}$ of small Amazonian streams (Johnson et al., 2006). Although stream hydrochemistry data are scarce in these regions, studies have reported low stream concentrations for nutrients in a forested catchment in the central Amazon (Zanchi et al., 2015) as well in natural and disturbed catchments in the central and southwestern Cerrado (Silva et al., 2011, 2012). For some nutrients, i.e. F and Fe, we attributed this to the absence of fertilizer application in the pasture catchments during our study period and the poor soil nutrient conditions in both regions, which is typical of Lixisols (Driessen and Deckers, 2001) and Arenosols (Markewitz et al., 2006) because of their strongly weathered substrate. Additionally, the highly weathered soils fix available nutrients, especially $\mathrm{P}$, in the form of $\mathrm{Fe}$ and $\mathrm{Al}$ sesquioxides (Uehara and Gillman, 1981). Indeed, the soils from all catchments exhibited a high content of $A l$ and Fe and, a characteristic often found in Amazon (Quesada et al., 2011; Dos Santos and Alleoni, 2013) and Cerrado soils (Buol, 2009).

Soil $\mathrm{pH}$ in the pasture catchments was higher than that in the native vegetation catchments, which has also been reported in other studies in other regions of the Amazon (Mazzetto et al., 2016) and Cerrado (Neufeldt et al., 2002; Carvalho et al., 2007; Hunke et al., 2015b). This is owing to liming practices in the pasture catchments. Lime $\left(\mathrm{CaCO}_{3}\right)$ is often applied to acidic soils in these regions to increase soil pH (Couto et al., 1997; Jepson et al., 2010; Moreira and Fageria, 2010). Therefore, Ca content was higher in the soils of the pasture catchments than in the soils of the native vegetation catchments. The pasture catchments exhibited significantly higher stream Ca concentrations, which reported in in other studies in the Amazon (Biggs et al., 2002; Figueiredo et al., 2010) and Cerrado (Markewitz et al., 2011; Silva et al., 2011). 


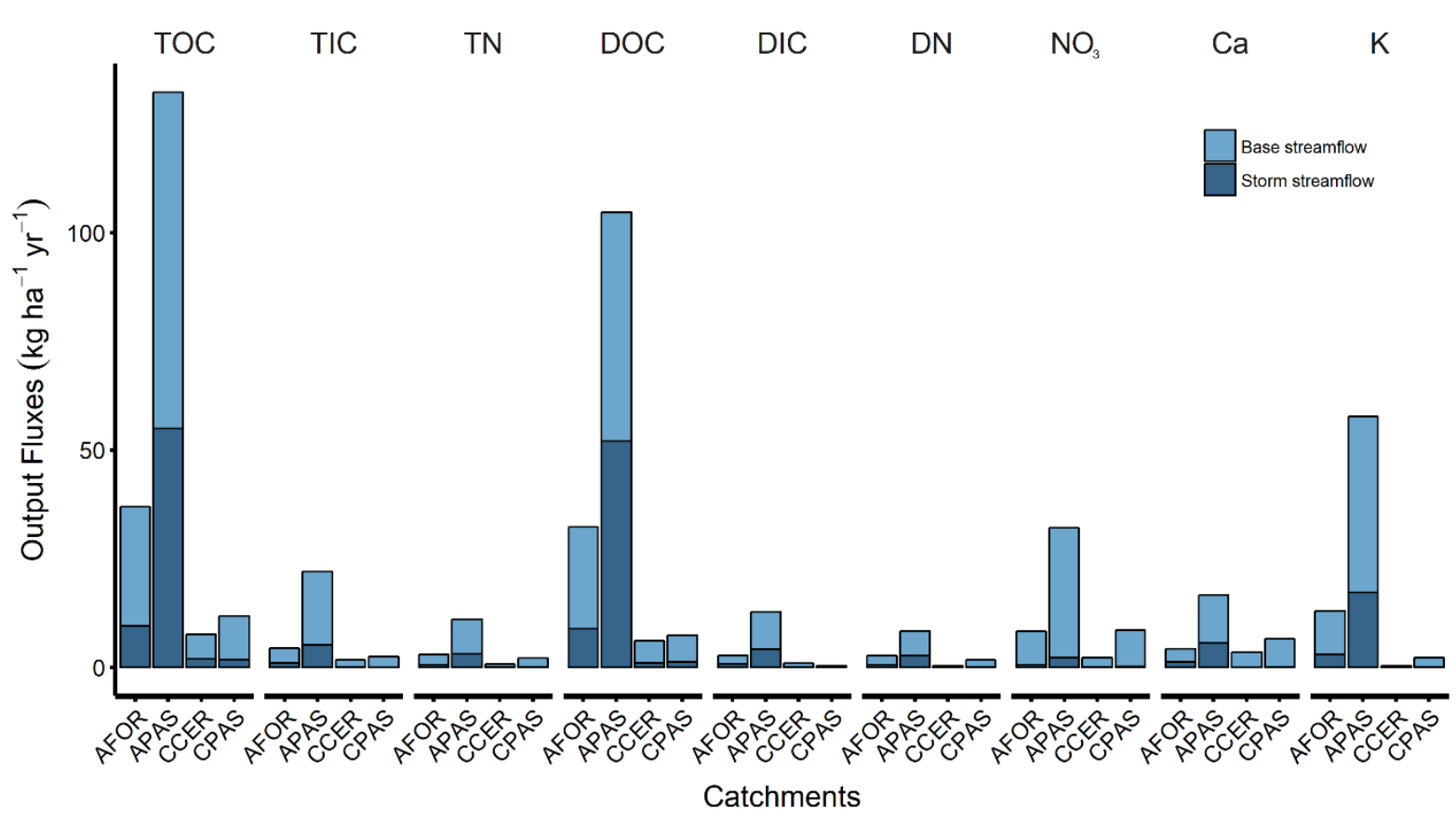

Figure 6.5 Annual carbon and nutrient output fluxes of base streamflow $\left(S_{b}\right)$ and storm streamflow $\left(\mathbf{S}_{\mathrm{s}}\right)$.

The significantly higher $\mathrm{S}_{\mathrm{s}} \mathrm{Ca}$ concentrations exhibited in the CPAS catchment compared to those of the CCER catchment indicates that liming practices are increasing $\mathrm{Ca}$ content in the topsoil of the CPAS catchment and facilitating the leaching of this element to the stream during stormflow events. Other studies have already reported that the high rainfall rates in the Cerrado are sufficient to solubilize and leach fertilizers such as Ca (Villela and Haridasan, 1994; Hunke et al., 2015a). Conversely, between the Amazonian catchments, the Ca concentrations in stream water were significantly higher in the APAS, but only in $\mathrm{S}_{\mathrm{b}}$. Such an enrichment of $\mathrm{Ca}$ in the $S_{b}$ has been observed in other studies in Brazil (Da Silva et al., 1998; Gonzatto, 2014), and we attribute this to the slow percolation of the residual lime through the soil profile (Rowe, 1982). Because Lixisols are in an advanced weathering stage (Quesada et al., 2011) and characterized by a low cation exchange capacity (Driessen and Deckers, 2001), the percolating soil water carries the residual $\mathrm{Ca}$, thereby increasing its concentration in the $\mathrm{Sb}$. In contrast, during storm events, the surface runoff dilutes the $\mathrm{Ca}$ concentration in the $\mathrm{Sb}$, resulting in similar concentrations between the Amazonian catchments. Biggs et al. (2002) found strong correlations between the soil exchangeable cation content and the concentration of stream solutes and suggested that pasture age may help explain the substantial variation in solute concentration 
responses to deforestation, especially for $\mathrm{Ca}$. DIC presented dynamics similar to $\mathrm{Ca}$; its differences within the Amazonian and Cerrado catchments occur in the same flow types, and they are grouped in the same components in all PCAs. We ascribe this to be a consequence of liming practices. As lime is applied, the $\mathrm{CaCO}_{3}$ reacts with water, increasing the soil $\mathrm{pH}$ and producing $\mathrm{HCO}_{3}$, which is one of the main $\mathrm{DIC}$ components and has been identified as a main driver of DIC fluxes in small streams in the Amazon (Johnson et al., 2006; Cak et al., 2015).

We found $\mathrm{NO}_{3}$ concentrations to be significantly different only between the Cerrado catchments, with higher values in the CPAS catchment. The increase in $\mathrm{NO}_{3}$ concentrations due to deforestation in Amazonian streams are not as clear (Figueiredo et al., 2010; Silva et al., 2007; Williams and Melack, 1997) as they are in the Cerrado (Silva et al., 2011). It has been reported that the high percentage of mineralized $\mathrm{N}$ nitrified in forests is the cause of a high potential for $\mathrm{NO}_{3}$ loss in soil solution and streamwater when these forests are cleared and burned (Neill et al., 2006; Vourlitis and Hentz, 2016), which has occurred in small catchments under recent or ongoing deforestation (Williams and Melack, 1997). The fact that we could not find this same relationship between the $\mathrm{NO}_{3}$ concentrations of the Amazonian catchments is consistent with patterns of $\mathrm{N}$ cycling and $\mathrm{N}$ availability, which shows high soil solution $\mathrm{NO}_{3}$ concentrations in Amazonian forests (Neill et al., 2001). The Amazonian forest behaves rather similar to old and temperate forests, which present high nitrification rates and $\mathrm{NO}_{3}$ pool losses that occur under normal conditions (Aber et al., 1989; Stevens et al., 1994; Neill et al., 2001). These forests may become net sources of nitrogen, thereby causing $\mathrm{NO}_{3}$ leaching to streams (Aber et al., 1995).

\subsubsection{Stream CAN output fluxes}

Except Except for DIC in the Cerrado catchments, the CAN fluxes were greater in the pasture catchments (Table 6.4). The Amazonian catchments exhibited the greatest differences in CAN fluxes. In these catchments, $S_{s}$ showed a greater difference between the APAS and AFOR catchments, with an average APAS:AFOR ratio 37\% higher than that in $\mathrm{Sb}$. Conversely, for the Cerrado catchments, the CPAS:CCER CAN ratios were, on average, $56 \%$ less in $\mathrm{S}_{\mathrm{s}}$ than in $\mathrm{S}_{\mathrm{b}}$. This is consistent with that fact that nutrients, especially $\mathrm{K}$ and $\mathrm{Ca}$, have been shown to have higher stream fluxes in 
pastures than in forests in the Amazon (Williams and Melack, 1997; Germer et al., 2009) and Cerrado (Figueiredo et al., 2010; Silva et al., 2011).

The total and dissolved carbon stream outputs were higher from the pasture catchments. Strey et al. (2016) found that degraded pasture areas exhibit lower organic carbon (OC) content than that of areas with native vegetation in the Cerrado and Amazon biomes, which is likely connected to larger losses of forest-derived OC after deforestation. In these biomes, the reduced organic carbon due to native vegetation clearing for pasture has been shown to be associated with reduced aggregate stability (Longo et al., 1999), which, in turn, has resulted in degraded pasture soils storing less carbon than soils covered with natural vegetation (Fonte et al., 2014). This facilitates carbon leaching and, consequently, increases the TOC and DOC fluxes. Kindler et al. (2011) affirmed that the quantification of DOC leaching from soil is crucial for the carbon balance. These authors found that losses of biogenic carbon from grasslands account for ca. $22 \%$ of the net ecosystem exchange, whereas leaching from forest sites hardly affects net ecosystem carbon balances. In the Amazon, the decreased soil carbon storage as a consequence of forest conversion to pastures has been reported to be directly correlated with pasture age (Asner et al., 2004). In the Cerrado, while well-managed pastures may sustain soil carbon content, most pastures in this biome are in advanced stages of degradation (Davidson et al., 2012). In this region, the sandy soils, such as the Arenosols, are commonly found and the decrease of their organic matter content owing to their increasingly use for agricultural practices (Speratti et al., 2017) is likely to increase the leaching of nutrients (Hunke et al., 2015a).

Table 6.4 Base streamflow, storm streamflow and total streamflow ratios of stream output fluxes for each pair of catchments.

\begin{tabular}{|c|c|c|c|c|c|c|c|c|c|c|}
\hline Ratio & Flow type & TOC & TIC & TN & DOC & DIC & DN & $\mathrm{NO}_{3}$ & $\mathrm{Ca}$ & $\mathbf{K}$ \\
\hline APAS:AFOR & Base streamflow & 2.8 & 5.0 & 3.4 & 2.3 & 4.5 & 2.8 & 3.9 & 3.6 & 4.1 \\
\hline APAS:AFOR & Storm streamflow & 5.8 & 5.0 & 4.7 & 5.8 & 4.8 & 4.4 & 3.8 & 4.6 & 5.7 \\
\hline APAS:AFOR & Total streamflow & 3.6 & 5.0 & 3.7 & 3.2 & 4.6 & 3.2 & 3.9 & 3.8 & 4.4 \\
\hline CPAS:CCER & Base streamflow & 1.8 & 1.5 & 3.3 & 1.2 & 0.4 & 4.0 & 3.8 & 1.8 & 6.8 \\
\hline CPAS:CCER & Storm streamflow & 1.0 & 0.7 & 1.2 & 1.1 & 0.6 & 1.7 & 2.7 & 2.8 & 1.4 \\
\hline CPAS:CCER & Total streamflow & 1.6 & 1.4 & 3.0 & 1.2 & 0.4 & 3.7 & 3.7 & 1.8 & 5.5 \\
\hline
\end{tabular}


The results of $\mathrm{C}$ content and $\mathrm{C}: \mathrm{N}$ ratios for the Amazonian catchments are in accordance with studies on primary forests and old pastures in the Amazon (McGrath et al., 2001). For the Cerrado catchments, the C:N ratios are also similar to other results for topsoil in areas with cerrado vegetation and pasture in this biome (Figueiredo et al., 2010; Neufeldt et al., 2002). Similar to C, N output fluxes were higher in the pasture catchments. In comparison to the Cerrado catchments, the Amazonian catchments exhibited a lower $\mathrm{C}: \mathrm{N}$ ratio, which is typical for Oxisols in the uppermost horizon (Tardy et al., 2005), and has been identified as an important controlling factor of total ecosystem $\mathrm{N}$ retention. High C: $\mathrm{N}$ promotes $\mathrm{N}$ immobilization, reduces net nitrification and consequently contributes to greater $\mathrm{N}$ retention (Templer et al., 2012). This has direct implications for the net $\mathrm{N}$ fluxes in this region, as the atmospheric deposition of $\mathrm{N}$ (3.5-10 kg N ha-1 year $^{-1}$ (Bobbink et al., 2010; Salemi et al., 2015)) is exceeded by $\mathrm{N}$ output via streamflow in the APAS catchment. This indicates that the pastures in this region might be a sink for $\mathrm{N}$, as has been found in other studies in the Amazon (e.g., Germer et al., 2009 and Salemi et al., 2015).

Our results show the importance of $S_{s}$ as a significant contributor to $S_{t}$ CAN fluxes in catchments of the Amazon and Cerrado biomes. To illustrate this, we provide the ratios between the short-lived events $\left(S_{s}\right)$ to the $S_{t}$ duration, volume and CAN fluxes in Table 6.5. The $S_{s}: S_{t}$ duration ratios were only $4.9-5.3 \%$ in the Amazonian catchments and $1.7-2.1 \%$ in the Cerrado catchments. Nevertheless, the relatively small durations of the $S_{s}$ events caused an increase of $15.9-26.5 \%$ and $2.8-5.5 \%$ in the $S_{t}$ volume in the Amazonian and Cerrado catchments, respectively. Moreover, in nearly all cases the $S_{s}$ contribution to the $S_{t} C A N$ output fluxes was greater than its contribution to the $S_{t}$ volume. In the APAS catchment, $50 \%$ of the $S_{t}$ DOC output fluxes were caused by $S_{s}$. In the Cerrado catchments, $S_{s}$ fluxes accounted for $16-26 \%$ of the TOC total streamflow output fluxes, despite the $S_{s}$ contribution to $S_{t}$ volume of only approximately $2-5 \%$. This shows that $\mathrm{S}_{\mathrm{s}}$ is especially important as a rapid hydrological pathway for CAN losses in areas on the AAF where deforestation reduces the infiltration capacity rates, which are in turn exceeded by the rainfall intensities, causing greater stormflow contributions (Zimmermann et al., 2006). The substantial contribution exhibited by $S_{s}$ to $S_{t}$ CAN fluxes is mainly owing to their higher CAN concentrations compared to those of $S_{b}$. These concentrations may be higher in $S_{s}$ 
because of the rapid subsurface response in streams dominated by pre-event water, where a rapid mobilization of old water occurs (Kirchner, 2003), and to surface flow paths that contribute to higher CAN concentrations (Johnson et al., 2006).

DIC also exhibits a rapid response during stormflows in wet tropical catchments under pristine rainforest and agriculture LULC (Bass et al., 2014). In the Amazonian catchments, we found that $S_{s}$ represented slightly more than $30 \%$ of $S_{t}$ DIC fluxes, with similar $S_{s}: S_{t}$ DIC fluxes between these catchments. In contrast, $S_{s}$ DIC fluxes represented only $6 \%$ of the total output fluxes in the CCER catchment and $10 \%$ in the CPAS catchment.

Table 6.5 Percentage ratio of the storm streamflow duration, volume and fluxes to the total streamflow.

\begin{tabular}{cccccccccccc}
\cline { 3 - 10 } & & & \multicolumn{7}{c}{$\mathrm{S}_{s}: \mathrm{S}_{\mathrm{t}}$ (CAN fluxes) } \\
\hline Catchment & $\begin{array}{c}\mathrm{S}_{\mathrm{s}}: \mathrm{S}_{\mathrm{t}} \\
\text { (duration) }\end{array}$ & $\begin{array}{c}\mathrm{S}_{\mathrm{s}}: \mathrm{S}_{\mathrm{t}} \\
\text { (volume) }\end{array}$ & TOC & TIC & TN & DOC & DIC & DN & $\mathrm{NO}_{3}$ & $\mathrm{Ca}$ & $\mathrm{K}$ \\
\hline AFOR & $4.9 \%$ & $15.9 \%$ & $26 \%$ & $24 \%$ & $23 \%$ & $28 \%$ & $31 \%$ & $23 \%$ & $7 \%$ & $29 \%$ & $23 \%$ \\
\hline APAS & $5.3 \%$ & $26.5 \%$ & $42 \%$ & $23 \%$ & $28 \%$ & $50 \%$ & $33 \%$ & $32 \%$ & $7 \%$ & $34 \%$ & $30 \%$ \\
\hline CCER & $2.0 \%$ & $5.2 \%$ & $26 \%$ & $3 \%$ & $14 \%$ & $18 \%$ & $6 \%$ & $12 \%$ & $4 \%$ & $2 \%$ & $24 \%$ \\
\hline CPAS & $1.6 \%$ & $2.8 \%$ & $16 \%$ & $2 \%$ & $6 \%$ & $17 \%$ & $10 \%$ & $6 \%$ & $3 \%$ & $2 \%$ & $6 \%$ \\
\hline
\end{tabular}

While many recent studies showed insights of high-temporal monitoring schemes in areas with fairly easy access (e.g., close to urban centers accessed via paved roads) in Europe (e.g., Blaen et al., 2016; Cuomo and Guida, 2016) and North America (e.g., Jollymore et al., 2012; Sherson et al., 2015) as a valid and new approach to ensure appropriate management of the natural resources (Skeffington et al., 2015), our study uses this method to assess the impacts of LULC change in catchments located in data-scarce active zones of deforestation of the two largest biomes of South America.

Despite the contribution of our study contributes to the understanding of the hydrochemical fluxes on the AFF, the magnitude and duration of these impacts depend on several catchments characteristics (e.g., soils, morphology and geology) that should also be addressed in further studies (Birkinshaw et al., 2010). Long-term measurements (over 10 years) of stormflow events including quantifying changes in groundwater quality are required to analyze trends in water quality. Biggs et al. (2006) 
found evidence of long-term increases in solute fluxes following the conversion of forest to pasture in the Amazon. Hence, empirical studies that contemplate the comparison of pastures with different ages are fundamental to quantify the effect pasture age in CAN fluxes.

The degree to which the chemical changes of the streamwater in the Amazon and Cerrado biomes are affecting the CAN delivery to the ocean is poorly understood and difficult to assess (Bouchez et al., 2014). Notwithstanding, the changes in stream hydrochemistry are likely to unfold greater impacts due to several large dams under construction in this region (Tollefson, 2015; Pavanato et al., 2016), which will receive and store the increased loads of CAN and negatively affect their suitability as aquatic habitats. To that end, we recommend studies that take into account the long-term effects of LULC change on stream hydrochemistry in nested scales and their impacts in large watershed systems in this region.

\subsection{Conclusions}

Our research demonstrates how the conversion of natural vegetated landscapes (forest and cerrado) to pasture changes stream hydrochemistry, which can disturb the natural carbon and nutrient balance in the Amazon and Cerrado biomes. Stream carbon and nutrient concentrations were significantly higher in catchments where the native vegetation was replaced by pastures. These higher concentrations underlie further implications for carbon and nutrient fluxes as streamflow increase occurs, which is widely reported in this region as a consequence of the conversion of native vegetation into agricultural lands.

We found that most of the carbon and nutrient flux contributions of stormflow to total streamflow is proportionately greater than its respective volumetric contribution to stream discharge. This shows that stormflow is a substantial hydrological pathway for carbon and nutrient losses, including areas with small stormflow contribution, as shown in the Cerrado catchments. This indicates that the unaccounted stream carbon and nutrient fluxes derived from sampling approaches on a daily or weekly basis are substantially great. Our study confirms the need for detailed temporal data on stream hydrochemistry that include the sampling of short-lived stormflow events to not only to 
understand natural tropical ecosystems, but also to unveil impacts of anthropogenic changes in these environments.

Although the acquisition of high-temporal resolution data in tropical forests is often limited by logistical restraints, we recommend that further studies use novel monitoring techniques such as automatic overland flow sampling and real-time water-quality sensors to improve the understanding of hydrochemical pathways and fluxes in forest ecosystems under anthropogenic changes such as the Amazonian agricultural frontier.

\section{Acknowledgements}

This research was supported by the Bundesministerin für Bildung und Forschung (www.bmbf.de) through a grant to the CarBioCial project (grant number: 01 LL0902A). The authors also acknowledge financial support from the Fundação de Amparo à Pesquisa do Estado de Mato Grosso (www.fapemat.mt.gov.br; grant number: 335908/2012), the Brazilian National Council for Scientific and Technological Development (www.cnpq.br; grant number: 481990/2013-5), and the German Academic Exchange Service (DAAD). The authors also acknowledge the collaboration of field site hosts (Paraíso, Gianetta and Rancho do Sol farms); the field assistance of J. Macedo, A. Kirst, N. Bertão and T. Santos; and the technical support provided by A. Eykelbosh, A. Södje, J. Grotheer, P. Voigt and T. Zeppenfeld. The authors also wish to thank all six reviewers for their comments and suggestions. 
Chapter 7. Ecosystem services in the Amazon agricultural frontier: separating the wheat from the chaff in a functionally diverse riparian zone

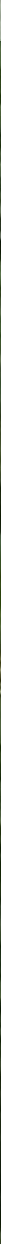




\title{
7. Ecosystem services in the Amazon agricultural frontier: separating the wheat from the chaff in a functionally diverse riparian zone
}

\begin{abstract}
The ecological services provided by pristine riparian zones in human-altered landscapes are widely acknowledged, yet little is known about them. In this study, we assess ecosystem properties that a protected riparian zone maintains in contrast to environmental changes in its surroundings caused by agro-industrial activities in the northwestern fringe of the Brazilian Cerrado, on the Amazonian agricultural frontier. We conducted a detailed assessment of the plant biodiversity, soil hydro-physical properties, and water quality, to understand at how the underlying ecological characteristics of a riparian zone sustain its neighboring cropland area. We show that the riparian zone is fundamental in providing key ecosystem regulating services, including maintenance of plant biodiversity, soil properties and water quality. Our results indicate that the protection of the plant biodiversity in the riparian zone sustain a synergy between plants and soil by promoting higher infiltration rates, higher soil porosity and natural soil chemistry conditions, which in turn has direct implications on the quality of water that becomes streamflow. Our study reaffirms that conservation of riparian zones is crucial to buffer the negative impacts of land-use conversion associated to agricultural practices on ecosystem services supply.
\end{abstract}

\subsection{Introduction}

The concept of ecosystem services is related to the benefits that the environment offers for human well-being, and it has become useful for promoting sustainable management of natural resources (Guzha et al., 2013). Essential ecosystem services, such as plant biodiversity, water provisioning, water quality regulation and soil carbon storage, are commonly provided by landscapes in pristine conditions (Guswa et al., 2014). When such environments are under threat by anthropogenic change, the vegetation is usually one of the first ecosystem components affected, which in turn can cause further impacts, such as soil degradation and water quality deterioration (Galford et al., 2010; Silva et al., 2011). The magnitude, types and scope of these impacts are still poorly understood, especially on landscape components such as the riparian zones (RZs), such as those found in agro-industrial regions (Skorupa et al., 2013). These RZs, also known as riparian vegetation, riparian corridors or riparian forests (Silva et al., 2008; Mcjannet et al., 2012; Bianchi and Haig, 2013; Ferraz et al., 2014), are often spared from deforestation in agricultural areas because they do not 
offer satisfactory agricultural productivity conditions (usually due to their high slope and frequent waterlogging conditions) (Tiwari et al., 2016) or because there are regulatory restrictions that require their conservation. This is a common situation for the RZs found in the Brazilian Cerrado, which has historically held the highest deforestation rates of the Amazon agricultural frontier (AAF) (Klink and Machado, 2005).

The conversion from natural land cover to crops and pastures has resulted in the reduction of the native fire-adapted savannah-like Cerrado vegetation to approximately $50 \%$ (ca. 1 million $\mathrm{km}^{2}$ ) of its original land cover (Mendonça et al., 1998; Klink and Machado, 2005; Lambin et al., 2013). The Cerrado is one of the world's critical hotspots for conservation due to its high amount of endemic species (Myers et al., 2000; Brooks et al., 2002; Myers, 2003; Brooks, 2006; Loyola et al., 2009), and is the savanna with the greatest plant diversity in the world (Mendonça et al., 1998). The Cerrado environment contains different vegetation formations, ranging from grasslands to forests, including the interspersed gallery forests, which are found in RZs and contain ca. 30\% of Cerrado plant biodiversity (Felfili et al., 2001; Ribeiro and Walter, 2008). Most plant species in the Cerrado RZs are commonly associated with Amazonian and Atlantic rainforests and display distinguished adaptations, enduring high level of root zone soil water levels (Oliveira-filho and Ratter, 1995), which is facilitated by their position along the watercourses. Further away from the RZs, the natural Cerrado landscape is occupied by other types of vegetation with lower water demand, which exhibit more open, grassy physiognomies that are substantially different from the gallery forests (Felfili and Silva Júnior, 1992). Gallery forests are occupied by plant species that have a higher leaf area index (Hoffmann et al., 2005) and biodiversity (Santiago et al., 2005; Silva-Júnior, 2005) than the other Cerrado vegetation types, with tree heights up to $40 \mathrm{~m}$ (Felfili, 1997).

On the AAF, the Brazilian Forest Code regulates the protection of the RZs, which are categorized as riparian preservation areas (Stickler et al., 2013; Soares-filho et al., 2014; Garrastazú et al., 2015). However, Nagy et al. (2015) has identified humaninduced degradation in an Amazon's agricultural landscape, which significantly decreased its biodiversity and regeneration capacity. In fact, it is well-known that the application of pesticides and fertilizers in agricultural lands cause anthropogenic 
pressure, endangering the ecological functions of the RZs (Gregory et al., 1991). In other parts of the world, there is evidence that natural RZs act as buffer zones, filtering nutrients and pollutants (Addy et al., 1999; Daniels and Gilliam, 1996; Gyawali et al., 2013; Lowrance et al., 1984; Lowrance and Sheridan, 2005; Ranalli and Macalady, 2010; Randhir and Ekness, 2013; Smith et al., 2012), and reducing sediment load into streams (Daniels and Gilliam, 1996; Randhir and Ekness, 2013). Still, the width of the riparian buffer zone, i.e., the distance to the streams, which is used as a measure of protection of the native $R Z$ vegetation, is arbitrarily established in Brazil. Since an appropriate riparian width can substantially buffer the impacts of the agricultural activities (Mander and Tournebize, 2015), it is inferred that the riparian width should depend on the ecological functions that need to be protected (Newbold et al., 1980). One of the few studies in Brazil in this matter, conducted in the Atlantic Forest (Aguiar et al., 2015), showed that a 36-m riparian width retained $70-94 \%$ of pesticides. By contrast, the previous compulsory cut-off value of $30 \mathrm{~m}$ for restoration of the riparian width buffer zone of small streams was reduced to $15 \mathrm{~m}$ in the new Brazilian Forest Code of 2012. This reduction in the protected riparian width threatens the maintenance of water quality and availability in streams (Garrastazú et al., 2015).

The survival of many non-aquatic plants and animals depends upon the RZs of small forest headwater streams (Richardson et al., 2005). The understanding of the ecosystem properties in the $\mathrm{RZ}$ is fundamental to support further guidelines on riparian conservation (Bowler et al., 2012; Weigelhofer et al., 2012). The description of the ecological functioning of plant species in natural landscapes is limited in the literature, including data on the capacity of individual plant species to retain nutrients (Haridasan, 2008). The same applies for plant biodiversity, hydro-physical and chemical soil characteristics, and stream hydrochemistry in the RZs. Most environmental studies on the Cerrado RZs were conducted in areas surrounded by pristine savanna vegetation (e.g., Parron and Markewitz, 2010; van den Berg et al., 2012) and only a few studies analyzed the provision of RZ's ecosystem services in areas under intense anthropogenic influence (e.g., Ferraz et al., 2014), which are located outside of the AAF.

Despite the fact that RZs often represent a small portion of the altered landscapes, when protected, they can be natural barriers between these extended altered 
environments and entire stream networks. Considering the sum of individual benefits that hundreds of RZs provide at large scales, their relevance in environmental protection is amplified. However, the ecosystem services provided by RZs at the catchment level remain poorly understood, especially in the tropics (Iñiguez-Armijos et al., 2016; Luke et al., 2018). RZs on the AFF have suffered degradation (Macedo et al., 2013), and large streams that have historically been influenced by the agricultural expansion in this region have also shown upwards trends in nutrient fluxes (Nóbrega et al., 2018b).

Our work aims to improve the understanding of the ecosystem services provided by the Cerrado RZs, adding to an increasing body of evidence that recognizes the importance of RZs as ecological buffer zones. By analyzing field environmental data across different landscape gradients of a typical large-scale agro-industrial system with a RZ in the Cerrado of the AAF, we provide a detailed assessment of the associated plant biodiversity, soil hydro-physical properties, and water quality, showing the contrasting ecologies in the $R Z$ and its surrounding cropland area.

\subsection{Study area}

This study was conducted in the municipality of Campo Verde $\left(15.7381^{\circ} \mathrm{S}\right.$, $55.3618^{\circ} \mathrm{W}$ ) in the Brazilian state of Mato Grosso (Fig. 7.1). This region is characterized by a typical tropical savanna climate with a wet season extending from October to April, a dry season from May to September, rainfall averaging ca. 1,800 $\mathrm{mm}$ and the mean annual temperatures ranging from 18 to $24^{\circ} \mathrm{C}$ (Meister et al., 2017; Nóbrega et al., 2017). Dominant soils in the Cerrado (e.g., Arenosols and Ferralsols, IUSS Working Group WRB, 2015) are typically highly weathered and acidic with high aluminum concentrations, thus requiring fertilizers and lime for crop production and livestock farming (Hunke et al., 2015). 
(A)

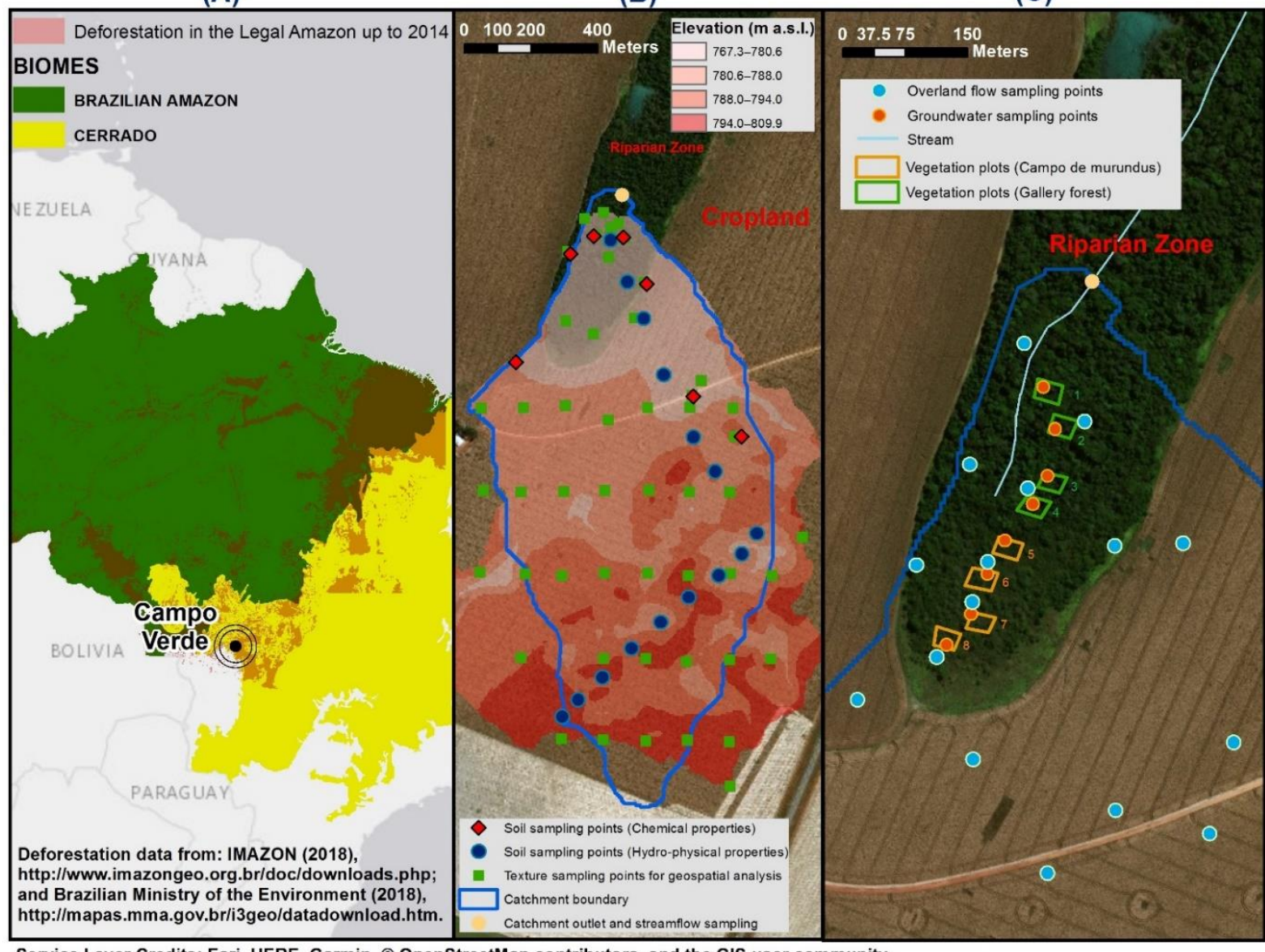

Service Layer Credits: Esri, HERE, Garmin, ( ) OpenStreetMap contributors, and the GIS user community

Source: Esri, DigitalGlobe, GeoEye, Earthstar Geographics, CNES/Airbus DS, USDA, USGS, AeroGRID, IGN, and the GIS User Community

Figure 7.1 Study area location: a) Amazon, Cerrado and the Campo Verde municipality; b) the study catchment with elevation and soil sampling points; c) a zoom to the riparian zone surroundings where the plots were surveyed and water samples were collected.

We selected a 93 ha catchment that lies within the das Mortes River basin $\left(15.743^{\circ} \mathrm{S}\right.$, $\left.55.363^{\circ} \mathrm{W}\right)$, the main tributary of Araguaia River. This catchment is on the Santa Luzia farm, an agro-industrial property with ca. 2,500 ha where agricultural activities have been expanding since the 1980s. The catchment area is dominated by cropland $(91 \%$ of the total area) with an average slope of $2.4 \%$. The cropland area is used for no-till mechanized rainfed agriculture based on crop rotation of soybean from October to January and maize from February to July. The RZ of this catchment occupies only $9 \%$ of the catchment area and has a mean slope of $4.9 \%$. The $R Z$ area is composed of a gallery forest and a campo de murundus Cerrado formation (Ribeiro and Walter, 2008) connected in a continuum manner and forming a mixture of typical plant species from Cerrado and Amazon and Atlantic rainforests (Oliveira-filho and Ratter, 1995; Marimon et al., 2002). Within this catchment, the average width is approximately $250 \mathrm{~m}$ for the 
gallery forest and $175 \mathrm{~m}$ for the campo de murundus. The campo de murundus is the vegetative community located closest to the stream. The campo de murundus is a subtype of Cerrado vegetation, and it is characterized by plain areas intertwined with large mounds, with the former colonized by herbaceous and shrub vegetation, and presenting mostly woody savannah species (Eiten, 1972; De Oliveira-Filho, 1992; Ponce and Cunha, 1993; Resende et al., 2004; Ribeiro and Walter, 2008; Marimon et al., 2012). Soils in the cropland catchment are Ferralsols (IUSS Working Group WRB, 2015) characterized by clay loam texture, and are correlated with Oxisols (Soil Survey Staff, 2014) and Latossolos Vermelhos Distróficos de textura argilosa (EMBRAPA, 2006).

\subsection{Methods}

\subsubsection{Vegetation survey}

Surveys were conducted in the $\mathrm{RZ}$ for the two vegetation formations (i.e., gallery forest and campo de murundus) in March (wet season) and September (dry season) of 2014 to consider the vegetative characteristics in both dominant seasons. For the surveys, we selected eight of $20 \times 30 \mathrm{~m}$ plots (total area of 4,800 $\mathrm{m}^{2}$ ) spaced approximately 50 $\mathrm{m}$ from each other along a 400-m transect from the gallery forest area near the stream to an area of the campo de murundus formation in transition to the cropland area (Fig. 7.1c). To characterize the plant biodiversity within the plots, we sampled woody individuals (dead and alive) with a minimum of $15.5 \mathrm{~cm} \mathrm{DBH}$ (diameter at breast height) as well as with a minimum of $15.5-\mathrm{cm}$ trunk diameter at $30 \mathrm{~cm}$ above ground height, which is an adequate measurement for small and mid-sized plants in similar Cerrado vegetation types (Phillip, 1994). We collected vegetative and fertile plant specimens that could not be identified in the field for posterior identification at the Tangará da Serra herbarium of the Mato Grosso State University (UNEMAT).

\subsubsection{Soil sampling and analysis}

To regionalize soil properties, we delineated transects for soil sampling based on the surface elevation and geostatistical analysis of the clay content (Fig. 1b). We used the DEMs derived from a topographic survey for the surface elevation analysis, and collected 55 disturbed soil samples at the $0-20 \mathrm{~cm}$ soil depth from randomly selected points throughout the catchment for clay content analysis. We interpolated the clay 
content values using isotropic variogram analysis and the ordinary kriging method, which exhibited a correlation coefficient of 0.92 , and then we validated the interpolation by using the leave-one-out cross-validation method (Herbst et al., 2006). This procedure allowed the categorization of the surface elevation in 5 equal intervals and clay content in quintiles and delineated transects from the catchment's crest to the stream valley passing over all elevation and clay content categories.

For the hydro-physical analysis, we selected 2 points in the $R Z$ and 13 in the cropland area approximately equally-spaced along the transects to collect one disturbed sample and two undisturbed soil core samples $(4.8 \mathrm{~cm}$ in diameter and $5.2 \mathrm{~cm}$ in height) at depth intervals of $0-10,10-20,20-40$, and $40-60 \mathrm{~cm}$ for each sampling point. The disturbed soil samples were analyzed to obtain the particle size distribution, and the undisturbed samples were used to determine bulk density, saturated hydraulic conductivity ( $\mathrm{K}_{\text {sat }}$ ), total porosity, macroporosity, microporosity, and field capacity. These procedures are in line with the soil geostatistical and hydro-physical analyses conducted by Nóbrega et al. (2017) in catchments located in the das Mortes River basin.

For the soil chemical analysis, we collected soil samples at 5 and $30 \mathrm{~cm}$ depths in 4 points in the $R Z$ and 3 points in the cropland area (Fig. 7.1b). The collection of soil samples for chemical analysis was primarily focused on understanding the effects of land-use on the overland flow quality. Therefore, we restricted the soil sampling to areas where we detected overland flow generation, i.e., overland flow sampling points, considering the different elevation and clay categories defined for the regionalization of the soil properties. We analyzed these soil samples to determine $\mathrm{pH}$, total carbon (TC), total nitrogen (TN), calcium (Ca), potassium (K), magnesium $(\mathrm{Mg})$, phosphorus $(\mathrm{P})$, and sulfur (S) at the Laboratory of Landscape Ecology at the University of Goettingen, Germany. pH was measured by using the potentiometric method (inoLAB® pH Level 2, Wissenschaftlich-Technische Werkstätten GmbH). TC and TN were quantified by using the elemental analysis method (TruSpec ${ }^{\circledR} \mathrm{CHN}$, LECO Instrumente $\mathrm{GmbH}$ ). The total digestion of $100-150 \mathrm{mg}$ of soil was made with $\mathrm{HClO}_{4}$, $\mathrm{HF}$ and $\mathrm{HNO}_{3}$ in $30 \mathrm{~mL}$ PTFE vessels (Pressure Digestion System DAS 30, PicoTrace $\mathrm{GmbH}$ ) and used to determine chemical concentrations by using atomic spectroscopy (ICP-OES, Optima $4300^{\mathrm{TM}}$ DV PerkinElmer). 


\subsubsection{Water sampling and analysis}

An automatic water sampler $\left(B L 2000^{\circledR}\right.$, Hach-Lange $\left.\mathrm{GmbH}\right)$ was installed at the outlet of the catchment inside the $R Z$ to collect stream water samples at $20 \mathrm{~cm}$ below the water surface during the 2013-2014 hydrological year. The sampling procedure was based simultaneously on both time and water level variation in order to represent the streamflow either during baseflow or stormflow prevailing conditions, respectively. The sampling routine was based on filling a 1-L sample bottle in 3 days by using an extraction of $200 \mathrm{~mL}$ from the stream at $14.4 \mathrm{~h}$ intervals. The stormflow sampling was determined by a sub-hourly routine activated by water level increase, detected by a pressure bell switch (FD-01, Profimess GmbH).

Overland flow samples were collected by using self-made overland flow detectors (OFDs) (Kirkby et al., 1976; Elsenbeer and Vertessy, 2000), consisting of a $50 \mathrm{~mm}$ diameter PVC tubes with a permeable section with $5 \mathrm{~mm}$ holes connected at a right angle by a "tee" to a reservoir section tube with $200 \mathrm{~mL}$ capacity. The contact of the detector section with the soil diverted the ponded overland flow into the reservoir tube. After field observations during rainfall events, we placed OFDs on observed flowpaths in the $R Z$ and in the cropland area (Fig. 7.1b). We installed the OFDs during the wet season and collected the samples within $12 \mathrm{~h}$ after the rainfall events. Additionally, to evaluate potential impacts of the cropland on the groundwater of the $R Z$, samples were taken twice per month in the wet and dry season from eight wells, each located in one of the eight vegetation survey plots.

The transportation, analysis and quality control of the water samples followed the same procedure described in Nóbrega et al. (2018). The water samples were protected from light following collection and transported in coolers packed with ice to the Ecofisiologia Vegetal Laboratory (EVL) of the Federal University of Mato Grosso (UFMT) in Cuiabá, Mato Grosso. At the laboratory, the water sample in each bottle was used to fill two aliquots of $50 \mathrm{~mL}$ in high-density polyethylene bottles pre-washed with deionized water. One aliquot was used for the analysis of total organic carbon (TOC), dissolved organic carbon (DOC), dissolved inorganic carbon (DIC) and TN, and the other aliquot was filtered through pre-ashed glass fiber filters $(0.7 \mu \mathrm{m}$ nominal pore size, Whatman GF/F) pre-washed with $20 \mathrm{~mL}$ of water sample for the remaining 
analyses. The samples were then frozen and shipped in Styrofoam coolers for analysis at the Laboratory of the Department of Landscape Ecology, University of Goettingen, Germany. The quality control of this procedure was conducted by comparing the DOC of water samples within $12 \mathrm{~h}$ after collection using a UV-Vis spectrometric device (spectro::lyser ${ }^{\text {TM }}$ UV-Vis, s::can Messtechnik $\mathrm{GmbH}$ ) with the DOC results obtained in the laboratory after final transportation and assuring that the results were not significantly different (Nóbrega et al., 2018).

TOC, DOC and DIC concentrations in water were determined by using high temperature catalytic oxidation (TC-Analyzer, DIMATOC 100 (R), Dimatec $\mathrm{GmbH}$ ). Total nitrogen (TN) concentration was quantified by using the chemiluminescence detection method (DIMA_N module (CLD), Dimatec $\mathrm{GmbH}$ ). $\mathrm{SO}_{4}$ concentrations were determined by using ion chromatography (761 Compact IC, Metrohm, Switzerland). Dissolved $\mathrm{K}, \mathrm{Ca}, \mathrm{P}, \mathrm{SO}_{4}$, and $\mathrm{Mg}$ concentrations were quantified by using atomic spectroscopy (ICP-OES, Optima $4300^{\mathrm{TM}} \mathrm{DV}$, PerkinElmer). Before the analyses of the dissolved solutes, the water samples were filtered through membrane filters $(0.45 \mu \mathrm{m}$ nominal pore size, cellulose acetate, Sartorius Stedim Biotech $\mathrm{GmbH}$ ). These filters were pre-washed with ultrapure water, transferred to HDPE bottles pre-washed with nitric acid solution $\left(2.6 \% \mathrm{HNO}_{3}\right)$ and rinsed with ultrapure water.

\subsubsection{Statistical analyses}

Data on soil properties were compared using the Mann-Whitney $U$ nonparametric test due to their non-normal distributions to determine whether the results from the $R Z$ and cropland area were significantly different from each other. Soil $\mathrm{pH}$ was converted to $\mathrm{H}_{3} \mathrm{O}$ for statistical comparison because of the non-linearity of these values. To compare the water quality parameters from the different hydrological pathways, we used the Kruskal-Wallis $\mathrm{H}$ test by ranks with the Steel-Dwass-Critchlow-Fligner (Fligner, 1984) method for multiple comparisons. We used the language and environment R v. 3.5.1 (R Core Team, 2017), the XLSTAT-Base v. 2018.6 software (Addinsoft, Paris, France, www.xlstat.com), with a significance threshold of 0.05 . However, because no significant difference at this level was found for the soil chemistry, we considered the significance threshold for these results at 0.057 . 


\subsection{Results}

\subsubsection{Riparian Zone Vegetation}

The 378 individuals sampled in the plots across the $\mathrm{RZ}$ revealed a floristic composition of 66 species belonging to 28 families (Appendix C). The most abundant botanical families in the campo de murundus plots were Euphorbiaceae, Melastomataceae and Simaroubaceae. In this formation, a total of 15 botanical families were found, adding up to a total of 242 living individuals and 17 dead individuals belonging to 27 different plant species. In the gallery forest, the most abundant plant families were Burseraceae and Anacardiaceae.

The first four plots (Plots 1-4), located in the gallery forest, were dominated with plant species that are primarily distributed in the Amazon rainforest, Atlantic rainforest and Cerrado vegetation (Fig 7.2a; Oliveira-Filho and Ratter, 1995; Flora do Brasil 2020, http://floradobrasil.jbrj.gov.br). The last four plots (Plots 5-8) are in the campo de murundus, where an increasing predominance of Cerrado-related vegetation and a decrease in Amazon-related vegetation exist. As the plots were located further from the gallery forest and stream network and closer to the cropland area, typical Cerrado species began to predominate for increasing distance from the stream. The predominance of tropical wet forests over dry vegetation types in the gallery forest are evident, and the opposite relationship was exhibited in the campo de murundus area (Fig. 7.2b).

(a)

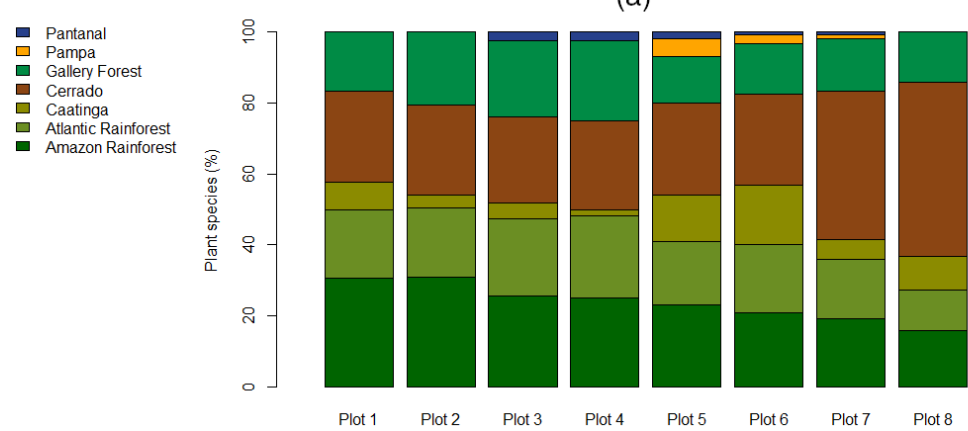

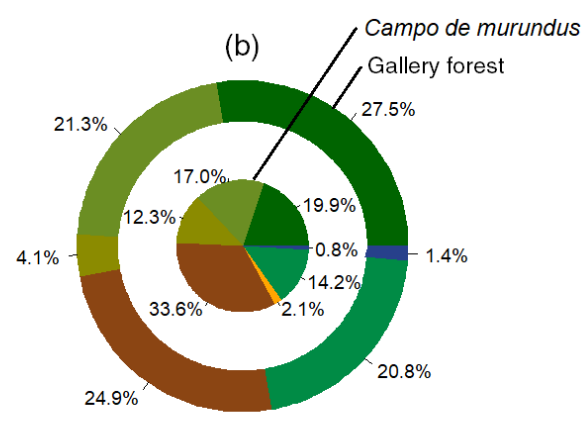

Figure 7.2 (a) Assembly and phytogeographic distribution of the surveyed plant species along the plots; (b) Percentage of the represented phytogeographic domains according to the two vegetation formations in RZ transect. Outer circle represents gallery forest (plots 1-4) and inner circle campo de murundus (plots 5-8). 


\subsubsection{Soil hydro-physical and chemical properties}

Soil hydro-physical properties of both $\mathrm{RZ}$ and cropland have a clay-loam texture (Table 7.1). The cropland area only shows a greater clay content in the topsoil compared to the RZ. The bulk density values in the RZ were significantly lower than those in the cropland area $(p<0.01)$. Ksat and field capacity did not show significant differences between these areas, but total porosity was significantly different for the upper layer $(0-10 \mathrm{~cm})$, with higher values in the RZ. In both areas the soil total porosity is dominated by about $75 \%$ micropores due to the high clay content (58 $\pm 7 \%$, average of both areas). The soil acidity was significantly higher $(p=0.057)$ in the $R Z$ than in the cropland area at the $5-\mathrm{cm}$ soil depth (Table 7.2). The soil nutrient content analysis showed that the cropland area had higher $\mathrm{Ca}$ and $\mathrm{P}$ content than the $\mathrm{RZ}$ at both soil depths, and higher Mg content at 5-cm soil depth.

Table 7.1 Soil hydro-physical properties.

\begin{tabular}{|c|c|c|c|c|c|c|c|c|c|}
\hline $\begin{array}{c}\text { Soil } \\
\text { depth } \\
(\mathrm{cm})\end{array}$ & $\begin{array}{c}\mathrm{BD} \\
\left(\mathrm{g} \mathrm{cm}^{-3}\right)\end{array}$ & $\begin{array}{l}\mathrm{TP} \\
(\%)\end{array}$ & $\begin{array}{l}\mathrm{MaP} \\
(\%)\end{array}$ & $\begin{array}{l}\mathrm{MiP} \\
(\%)\end{array}$ & $\begin{array}{l}\mathrm{FC} \\
(\%)\end{array}$ & $\begin{array}{c}\mathrm{K}_{\mathrm{sat}} \\
\left(\mathrm{mm} \mathrm{h}^{-1}\right)\end{array}$ & $\begin{array}{l}\text { Sand } \\
(\%)\end{array}$ & $\begin{array}{l}\text { Silt } \\
(\%)\end{array}$ & $\begin{array}{l}\text { Clay } \\
(\%)\end{array}$ \\
\hline \multirow{2}{*}{$0-10$} & $1.18 \pm 14 \%^{a}$ & $59.1 \pm 8 \% \%^{a}$ & $10.5 \pm 40 \%{ }^{a}$ & $48.7 \pm 10 \%^{\mathrm{a}}$ & $39.4 \pm 12 \%^{\mathrm{a}}$ & $42.9 \pm 154 \%^{\mathrm{a}}$ & $26.5 \pm 56 \% \%^{\mathrm{a}}$ & $16.0 \pm 41 \%{ }^{\mathrm{a}}$ & $57.6 \pm 17 \% \%^{\mathrm{a}}$ \\
\hline & $(0.86 \pm 9 \%)^{b}$ & $(69.1 \pm 9 \%)^{b}$ & $(22.5 \pm 3 \%)^{b}$ & $\begin{array}{l}(46.6 \pm \\
12 \%)^{\mathrm{a}}\end{array}$ & $\begin{array}{l}(40.7 \pm \\
14 \%)^{\mathrm{a}}\end{array}$ & $(130.4 \pm 68 \%)^{\mathrm{a}}$ & $\begin{array}{l}(35.4 \pm \\
18 \%)^{\mathrm{a}}\end{array}$ & $(13.1 \pm 14 \%)^{\mathrm{a}}$ & $(51.5 \pm 16 \%)^{a}$ \\
\hline \multirow[b]{2}{*}{$10-20$} & $1.19 \pm 11 \%{ }^{a}$ & $56.9 \pm 7 \%^{\mathrm{a}}$ & $13.6 \pm 33 \%^{\mathrm{a}}$ & $43.3 \pm 13 \%^{\mathrm{a}}$ & $35.9 \pm 14 \%^{\mathrm{a}}$ & $166.9 \pm 93 \%{ }^{a}$ & $25.5 \pm 50 \%^{\mathrm{a}}$ & $22.0 \pm 37 \%^{\mathrm{a}}$ & $52.5 \pm 14 \%^{\mathrm{a}}$ \\
\hline & $(0.95 \pm 10 \%)^{b}$ & $(60.1 \pm 8 \%)^{\mathrm{a}}$ & $\begin{array}{l}(15.0 \pm \\
18 \%)^{\mathrm{a}}\end{array}$ & $\begin{array}{l}(45.7 \pm \\
17 \%)^{\mathrm{a}}\end{array}$ & $\begin{array}{c}(39.9 \pm \\
19 \%)^{\mathrm{a}}\end{array}$ & $(302.8 \pm 12 \%)^{\mathrm{a}}$ & $\begin{array}{l}(29.2 \pm \\
35 \%)^{\mathrm{a}}\end{array}$ & $(16.0 \pm 5 \%)^{\mathrm{a}}$ & $(54.8 \pm 20 \%)^{\mathrm{a}}$ \\
\hline \multirow{2}{*}{$20-40$} & $1.16 \pm 11 \%^{\mathrm{a}}$ & $57.1 \pm 9 \%^{\mathrm{a}}$ & $16.2 \pm 35 \%{ }^{\mathrm{a}}$ & $41.0 \pm 10 \%{ }^{\mathrm{a}}$ & $34.2 \pm 13 \%^{\mathrm{a}}$ & $95.5 \pm 163 \%^{\mathrm{a}}$ & $25.3 \pm 57 \%^{\mathrm{a}}$ & $19.4 \pm 29 \%^{\mathrm{a}}$ & $55.4 \pm 19 \%^{\mathrm{a}}$ \\
\hline & $(0.94 \pm 13 \%)^{\mathrm{a}}$ & $\begin{array}{l}(63.3 \pm \\
11 \%)^{\mathrm{a}}\end{array}$ & $\begin{array}{l}(15.6 \pm \\
47 \%)^{\mathrm{a}}\end{array}$ & $\begin{array}{l}(47.6 \pm \\
30 \%)^{\mathrm{a}}\end{array}$ & $\begin{array}{l}(41.1 \pm \\
31 \%)^{\mathrm{a}}\end{array}$ & $(69.9 \pm 83 \%)^{\mathrm{a}}$ & $\begin{array}{l}(26.0 \pm \\
35 \%)^{\mathrm{a}}\end{array}$ & $(13.0 \pm 40 \%)^{\mathrm{a}}$ & $(61.0 \pm 23 \%)^{a}$ \\
\hline \multirow{2}{*}{$40-60$} & $1.19 \pm 9 \% \%^{a}$ & $56.7 \pm 9 \%{ }^{\mathrm{a}}$ & $11.8 \pm 29 \%^{\mathrm{a}}$ & $44.9 \pm 9 \% \%^{\mathrm{a}}$ & $36.7 \pm 11 \%^{\mathrm{a}}$ & $51.9 \pm 162 \%^{\mathrm{a}}$ & $19.4 \pm 12 \% \%^{\mathrm{a}}$ & $21.4 \pm 12 \%$ & $59.3 \pm 6 \%^{\mathrm{a}}$ \\
\hline & $(1.07 \pm 3 \%)^{b}$ & $(57.8 \pm 1 \%)^{\mathrm{a}}$ & $\begin{array}{l}(14.8 \pm \\
41 \%)^{\mathrm{a}}\end{array}$ & $\begin{array}{c}(43.1 \pm \\
13 \%)^{\mathrm{a}}\end{array}$ & $\begin{array}{c}(37.2 \pm \\
12 \%)^{\mathrm{a}}\end{array}$ & $(53.3 \pm 55 \%)^{\mathrm{a}}$ & $\begin{array}{l}(23.8 \pm \\
32 \%)^{\mathrm{a}}\end{array}$ & $(9.9 \pm 40 \%)^{b}$ & $(66.4 \pm 17 \%)^{a}$ \\
\hline
\end{tabular}

Results are expressed in terms of average and relative standard deviation. The results without parentheses are for the cropland area, and the results between parentheses are results for the riparian zone.

Significant differences $(\mathrm{p}<0.05)$ are indicated by different letters and highlighted in bold. Comparisons were performed between Riparian Zone and Cropland at each soil property and depth.

$* \mathrm{BD}=$ Bulk Density, $\mathrm{TP}=$ Total Porosity, $\mathrm{MaP}=$ Macroporosity, MiP $=$ Microporosity, FC $=$ Field Capacity, $\mathrm{K}_{\text {sat }}=$ Saturated Hydraulic Conductivity.

\subsubsection{Water quality}

The Kruskal-Wallis $\mathrm{H}$ test by ranks with the multiple comparison (Steel-DwassCritchlow-Fligner method) exhibited the water quality varying from three to five groups with similar mean values (Fig. 7.3). Mg was the parameter with less groups (3) and with the smallest variation $\left(0-6 \mathrm{mg} \mathrm{L}^{-1}\right)$. The other nutrients with 3 groups were TOC (0.3-312.2 $\left.\mathrm{mg} \mathrm{L}^{-1}\right)$, TN $\left(0.1-18.5 \mathrm{mg} \mathrm{L}^{-1}\right)$ and $\mathrm{P}\left(0-13.3 \mathrm{mg} \mathrm{L}^{-1}\right)$. DOC $\left(0.1-32 \mathrm{mg} \mathrm{L}^{-}\right.$ 
1), DIC (0-16.2 $\left.\mathrm{mg} \mathrm{L}^{-1}\right), \mathrm{K}\left(0-32.2 \mathrm{mg} \mathrm{L}^{-1}\right), \mathrm{Ca}\left(0.1-22.6 \mathrm{mg} \mathrm{L}^{-1}\right)$ and $\mathrm{SO}_{4}(0-20.8 \mathrm{mg}$ $\left.\mathrm{L}^{-1}\right)$ exhibited the greater number groups (5). The descriptive statistics of each nutrient and each hydrological path is shown in Appendix D.

Table 7.2 Mean, one standard deviation and sample size $(n)$ of soil chemical properties.

\begin{tabular}{|c|c|c|c|c|}
\hline & \multicolumn{2}{|c|}{ 5-cm soil depth } & \multicolumn{2}{|c|}{ 30-cm soil depth } \\
\hline & RZ & Cropland & $\mathrm{RZ}$ & Cropland \\
\hline $\mathrm{pH}$ & $3.8 \pm 0.2(4)^{\mathrm{a}}$ & $5.5 \pm 0.7(3)^{b}$ & $4.5 \pm 0.3(4)^{\mathrm{a}}$ & $4.9 \pm 0.4(3)^{a}$ \\
\hline Total C (\%) & $4.69 \pm 0.72(4)^{\mathrm{a}}$ & $3.57 \pm 0.65(3)^{\mathrm{a}}$ & $1.99 \pm 0.26(4)^{\mathrm{a}}$ & $1.89 \pm 0.30(3)^{\mathrm{a}}$ \\
\hline Total N (\%) & $0.30 \pm 0.05(4)^{\mathrm{a}}$ & $0.22 \pm 0.05(3)^{\mathrm{a}}$ & $0.15 \pm 0.07(4)^{\mathrm{a}}$ & $0.09 \pm 0.01(3)^{\mathrm{a}}$ \\
\hline $\mathrm{Ca}\left(\mathrm{mg} \mathrm{kg}^{-1}\right)$ & $77.4 \pm 44.9(4)^{a}$ & $2,389.0 \pm 1,781.8(3)^{b}$ & $34.9 \pm 11.7(4)^{\mathrm{a}}$ & $311.3 \pm 22.5(3)^{b}$ \\
\hline $\mathrm{K}\left(\mathrm{mg} \mathrm{kg}^{-1}\right)$ & $692.9 \pm 129.2(4)^{\mathrm{a}}$ & $786.4 \pm 167.2(3)^{\mathrm{a}}$ & $569.4 \pm 100.7(4)^{\mathrm{a}}$ & $639.3 \pm 31.6(3)^{\mathrm{a}}$ \\
\hline $\mathrm{Mg}\left(\mathrm{mg} \mathrm{kg}^{-1}\right)$ & $167.8 \pm 40.1(4)^{a}$ & $839.8 \pm 617.2(3)^{b}$ & $129.6 \pm 23.7(4)^{\mathrm{a}}$ & $190.7 \pm 38.1(3)^{\mathrm{a}}$ \\
\hline $\mathrm{P}\left(\mathrm{mg} \mathrm{kg}^{-1}\right)$ & $352.4 \pm 121.2(4)^{\mathrm{a}}$ & $1,244.7 \pm 487.8(3)^{b}$ & $187.9 \pm 53.8(4)^{a}$ & $430.1 \pm 69.8(3)^{b}$ \\
\hline $\mathrm{S}\left(\mathrm{mg} \mathrm{kg}^{-1}\right)$ & $372.1 \pm 14.5(4)^{\mathrm{a}}$ & $416.6 \pm 43.0(3)^{\mathrm{a}}$ & $208.8 \pm 29.0(4)^{\mathrm{a}}$ & $297.7 \pm 81.9(3)^{\mathrm{a}}$ \\
\hline
\end{tabular}

Most significant differences ( $p=0.057)$ are indicated by different letters and highlighted in bold. Comparisons were performed between Riparian Zone and Cropland at each soil depth.

Baseflow exhibited the lowest concentrations for all water quality parameters, whereas the overland flow in the cropland (hereafter referred to as OF-Cropland) area exhibited most of the highest nutrient concentrations. Except for $\mathrm{Ca}$, the differences between OF-Cropland and baseflow, stormflow and groundwater were all significant $(p<0.01)$ for all other nutrients. The overland flow in the $R Z$ (hereafter referred to as OF-RZ) also exhibited high nutrient concentrations that were significantly lower $(p<0.01)$ than OF-Cropland but still higher than the other hydrological fluxes, except for TOC, DOC and TN. OF-RZ showed significant differences in TOC, $\mathrm{TN}, \mathrm{Ca}$ and $\mathrm{SO}_{4}$ from streamflow (baseflow and stormflow). Difference between stormflow and OF-RZ were not significant for DOC, DIC, K, P and Mg. 
(a)

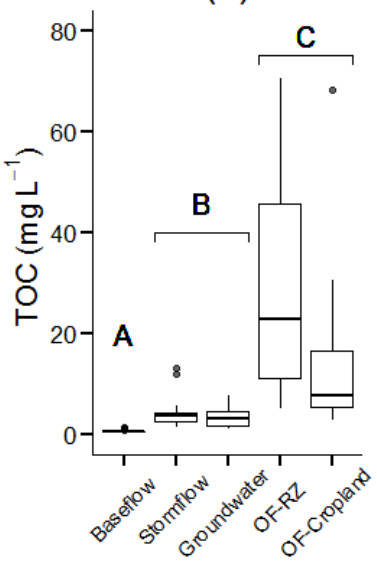

(d)

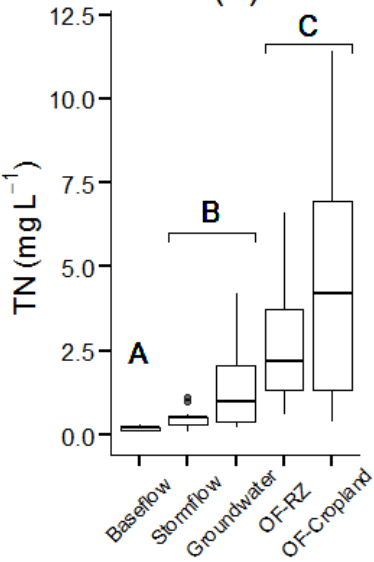

(g)

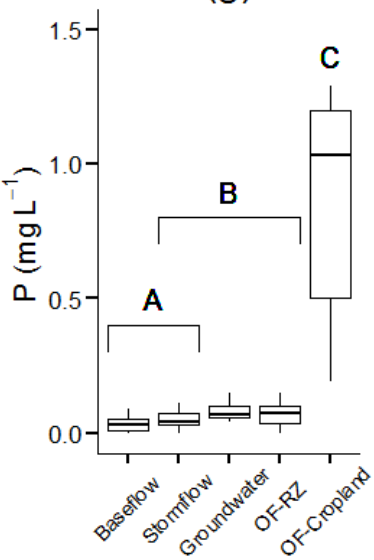

(b)

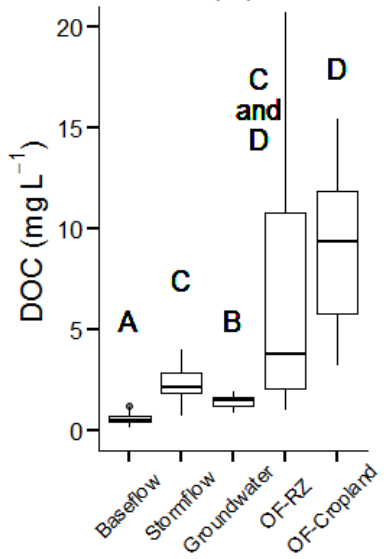

(e)

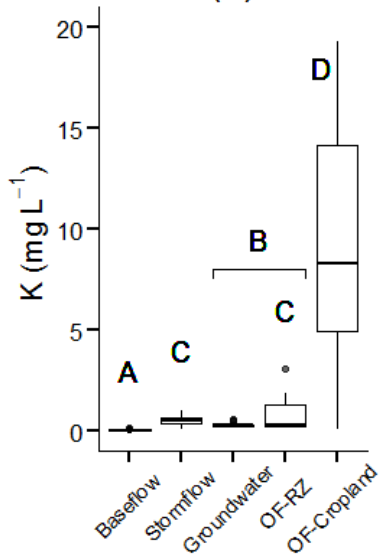

(h)

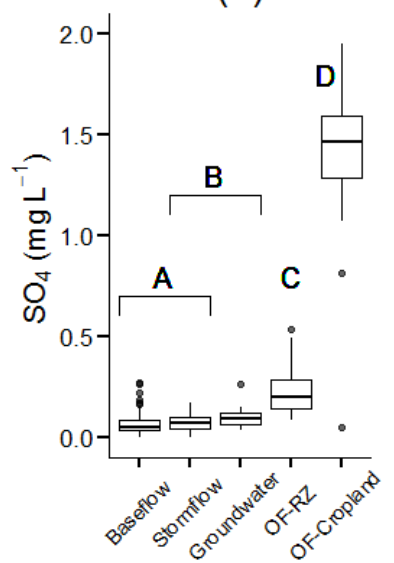

(c)

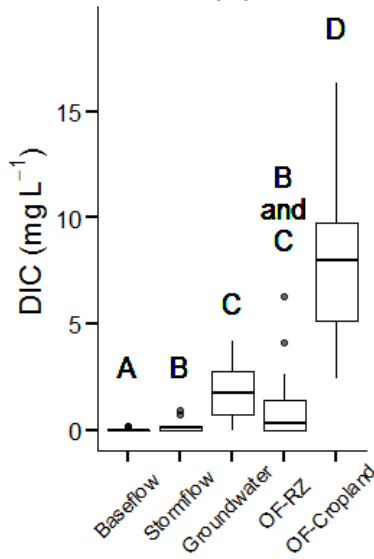

(f)

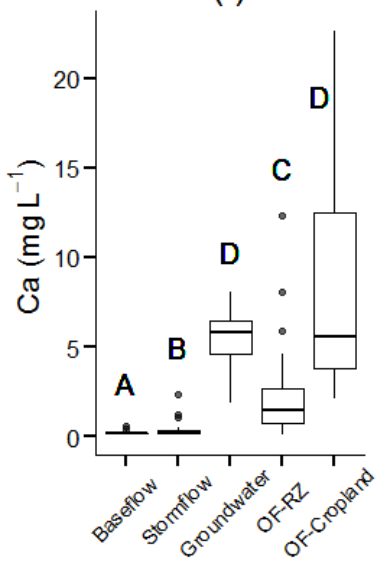

(i)

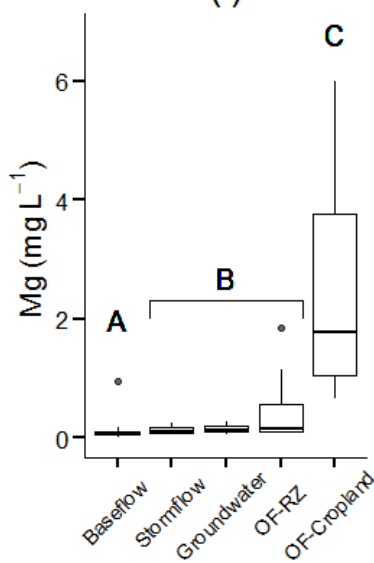

Figure 7.3 Boxplot of water quality parameters throughout the study are in different hydrological pathways. The y-axis was limited to graphically omit some outliers for a better visualization of the results. Significant differences $(p<0.05)$ are indicated by different letters. These letters follow an alphabetical order that correspond to groups with an ascendant order of mean of ranks. 


\subsection{Discussion}

\subsubsection{The functionally and evolutionarily diverse plant community}

Our botanical survey showed that the $R Z$ is richly assembled by species belonging to several clades or families in the plant tree of life (APG, 2016). Evolutionarily diverse plant communities are considered a key element for enhancing ecological functions by controlling light and temperature, offering shelter for biota, providing food for aquatic and terrestrial fauna, contributing with large and small woody debris that influence sediment directions, channeling morphology and microhabitats inside the river, controlling the flow of water and nutrients, and maintaining the local biodiversity (Décamps and Naiman, 1990; Naiman et al., 1993; Weisberg et al., 2013). The composition of plant species defines the efficiency of nutrient uptake from the soil and the water (Osborne and Kovacic, 1995). Functionally diverse plant communities are known to promote greater environmental stability because their associated multiple functional traits balance abiotic instability of buffer ecosystems (Cadotte et al., 2011). In our study, we found that the $R Z$ is ecologically dominated by the legume trees Tachigali vulgaris, Bowdichia virgilioides, Hydrochorea corymbosa and Ormosia paraensis, which are all known as nitrogen fixing species (Sprent, 2001). Tibouchina stenocarpa contributed with the greatest individual incidence in the RZ. This species in fact belongs to a genus that is well-known for its ability to colonize intensively degraded areas, thus contributing to their recovery (Lorenzo et al., 1994).

In the gallery forest, Tapirira obtusa was the most abundant, which is a pioneer species (Raaimakers and Lambers, 1996) that contributes to vegetation re-establishment by attracting seed dispersers (birds) (Pereira et al., 2012). In fact, we found several dead and juvenile individuals of Tapirira obtusa, which indicates that a regeneration process is underway (Goodale et al., 2012). The main common characteristic of the gallery forest and campo de murundus across the $\mathrm{RZ}$ was the predominance of pioneer species, which has important ecological roles, such as the recovery of a perturbed area or a degraded site by refilling canopy spaces inside the forest (Goodale et al., 2012). Similarly to Morais et al. (2013), we also observed the family Melastomataceae as having the greatest dominance in the campo de murundus. A relevant characteristic of this family is the capacity of intense regeneration in RZs, preparing the soil for the 
process of increasing forestation and facilitating the normal course of successional stages (Mendonça et al., 2008). The fruits of Melastomataceae generally produce great seed quantity for germinating and propagating new plants (Domingos et al., 2003; Fava and Albuquerque, 2009), which also supports the indication that this $R Z$ is under regeneration.

\subsubsection{Implications of $R Z$ conservation on soil and water quality}

The mean $\mathrm{K}_{\text {sat }}$ ranged from 43 to $167 \mathrm{~mm} \mathrm{~h}^{-1}$ in the cropland area and 53 to $303 \mathrm{~mm}$ $\mathrm{h}^{-1}$ in the RZ. We attribute the higher variability of $\mathrm{K}_{\text {sat }}$ in the cropland to the use of heavy farm machinery and field operations in this area, which follow precise established routes and impact the soil heterogeneously (cf. Fig. 7.1). Although modern agricultural approaches, i.e., no-till and precision farming, are often associated with low environmental impacts (Bongiovanni and Lowenberg-Deboer, 2004; Bramley et al., 2008; Jenrich, 2011), changes in the soil properties as a result of modern agriculture were reported by Hamza and Anderson (2005). Farming practices such as these, particularly for soybean cultivation, are reported to enhance subsoil compaction (Scheffler et al., 2011; Hunke et al., 2015). Indeed, we observed significant higher soil bulk density in the cropland area than in the $R Z$, and over a five-fold $K_{\text {sat }}$ decrease after the 10-20 cm soil depth interval in the cropland area, which indicates that the conservation of the $R Z$ maintains its soil properties and, consequently, the balance between water fluxes. These fluxes distribute nutrients in the soil through infiltration and runoff, influencing the vegetation composition and structure (Ravi et al., 2007). For example, undisturbed soil hydro-physical conditions that promote waterlogging in the campo de murundus are known to reduce the Fe-oxides (Oliveira and Marquis, 2002), which play an important role in driving soil biogeochemical processes during periods of anaerobiosis (Yang and Liptzin, 2015).

Plant species in the Cerrado are evolutionarily adapted to thrive on soils with low $\mathrm{pH}$ and nutrient content (Ruggiero et al., 2002). However, changes in the soil chemistry due to agricultural practices in this region disturb these soil conditions. We found higher $\mathrm{pH}$ at the topsoil of the cropland area than that of the RZ. Our results are consistent with other studies, such as Ruggiero et al. (2002), that showed the soil pH less than 4.5 for three distinguished Cerrado formations (Campo Cerrado, Cerrado 
sensu strictu and Cerradão). We attribute the lower acidity of the soil in the cropland area to the Calcium carbonate $\left(\mathrm{CaCO}_{3}\right)$ applied to the topsoil of this area, which is a common practice in the Cerrado and has the objective to reduce soil acidity and support nutrient availability to the crops. In our study area, the application of $\mathrm{CaCO}_{3}$ to croplands had implication on the soil Ca content, which was significantly higher in the topsoil of the cropland area. Further, as $\mathrm{CaCO}_{3}$ reacts with water, it produces bicarbonate $\left(\mathrm{HCO}_{3}\right)$, which is a main component of DIC. In fact, the $\mathrm{Ca}$ and $\mathrm{DIC}$ concentrations in the overland flow were significantly higher in the cropland area than in the RZ. Despite this, concentration of $\mathrm{Ca}$ and DIC in the streamflow was low compared to the other hydrological pathways. The groundwater in the $\mathrm{RZ}$ exhibited a concentration not as high as the overland flow but significantly higher than the one found in the streamflow. This shows evidence of long-term impacts of the topsoil application of $\mathrm{CaCO}_{3}$ on the soil profile and groundwater. As indicated by Nóbrega et al. (2018), residuals of the $\mathrm{CaCO}_{3}$ applied to the soil surface can percolate the soil profile and reach the stream via groundwater. In this context, the protected RZs are crucial to maintain natural soil properties in agricultural landscapes, as the Cerradoinhabiting plant species are adapted to these properties and can regenerate without nutrient additions, which in turn also protects the ecosystem from invasive plant species.

Haridasan (2000) observed C content between 0.74 and 3.33\% in soils located under Cerrado sensu stricto and Cerradão vegetation types and Parron and Markewitz (2010) showed N varying from 0.10 to $0.35 \%$ in Cerrado soils. Our results are similar to these studies with the $\mathrm{C}$ and $\mathrm{N}$ content reaching maximum mean values (ca. $5 \%$ for $\mathrm{C}$ and $0.3 \%$ for $\mathrm{N}$ ) at the $5-\mathrm{cm}$ soil depth of the $\mathrm{RZ}$ and minimum mean values (ca. $2 \%$ for $\mathrm{C}$ and $0.1 \%$ for $\mathrm{N}$ ) at the $30-\mathrm{cm}$ soil depth of the cropland area. We ascribe the greater $\mathrm{C}$ and $\mathrm{N}$ contents in the topsoil of the $\mathrm{RZ}$ to the natural processes in the gallery forest and campo de murundus, such as litterfall and high organic matter decomposition (Parron and Markewitz, 2010), which is more intense in RZ ecosystems (Aguiar Jr. et al., 2015). We ascribe the higher TOC concentration in the overland flow of the $R Z$ than in the cropland area as a result of this vegetation-soil interaction. Conversely, DOC and TN were higher in the cropland area, which a consequence of 
crop fertilization that causes nutrient leaching (Chantigny, 2003; Richardson et al., 2005; Pittaway et al., 2018).

We found significantly higher $\mathrm{P}$ and $\mathrm{Mg}$ at the topsoil of the cropland area than that of the RZ. Other studies (Tinker and Nye, 2000; Cruz Ruggiero et al., 2002; Haridasan, 2008; Silva et al., 2008) found nutrients, such as $\mathrm{K}, \mathrm{Mg}$ or $\mathrm{P}$, higher in cropland areas than in native vegetation zones without direct agricultural influence. Our results are likely due to regular fertilizer application to cropland area while undisturbed Cerrado soils are highly weathered and low in nutrients (Hunke et al., 2015). However, we were able to find a downward gradient of $\mathrm{K}, \mathrm{P}, \mathrm{SO}_{4}$ and $\mathrm{Mg}$ concentrations, which were highest in the overland flow of the cropland area, exhibiting a gradual decrease in concentration from the cropland area towards the stream. On a farm in the USA, Lowrance and Sheridan (2005) also verified the capacity of RZs in retaining nutrients, i.e., $\mathrm{NO}_{3}, \mathrm{NH}_{4}$ and $\mathrm{K}$. These results are also in agreement with earlier findings in the Cerrado by Parron and Markewitz (2010), who reported reduction of $\mathrm{N}$ and $\mathrm{P}$ in water fluxes going through an $R Z$ towards a stream.

Considering the hydrological pathways analysed, our overarching finding is that the nutrient overland flow from the cropland area is drastically higher than that of the streamflow. Our results indicate that a reduction or fragmentation of the $R Z$ to the advantage of cropland expansion can increase the soil bulk density, reduce its porosity and $K_{\text {sat, }}$ which in turn will increase the overland flow generation in the cropland towards the RZ. This aligns with findings from Alvarenga et al. (2017), who used the Distributed Hydrology Soil Vegetation Model (Sun et al., 2015) and found that increases in riparian width from 30 to $100 \mathrm{~m}$ in a catchment of $6.76 \mathrm{~km}^{2}$ in the Atlantic rainforest decrease $6.2 \%$ of total overland flow generation in the catchment.

\subsubsection{Uncertainties and research directions on RZ studies in agricultural landscape}

Our results uphold two main causes accredited to the capacity of RZs to act as buffers (Peterjohn and Correll, 1984). The first concerns the uptake of nutrients by RZ vegetation. Our findings agree with the fact that the vegetation and the soil in the RZs form a micro-environment, where the capillarity of the Cerrado's diverse RZ root plant system allows extensive contact with nutrients and their uptake by plants (Sternberg et al., 2005). The second is related to the capacity of the soils of RZs to reduce 
nutrients and pollutants, which is sustained by the hyporheic zone, a component of streams and rivers that interacts with the $R Z$ (Ward, 1989). The hyporheic zone acts as a water-purifying bioreactor that contains microbial biofilms, which in turn control biogeochemical fluxes of nutrients (Peralta-Maraver et al., 2018). Concerning the ecological buffering potential of RZs, there are, however, many variables that need to be considered in further studies, such as the residence time or the period of hydrodynamic retention in the hyporheic zone where biogeochemical processing of dissolved solutes occur (Buffington and Tonina, 2009). There is an ecosystem arrangement of these variables that may follow spatial and temporal nestings (PeraltaMaraver et al., 2018), which vary according to the different ecosystems and environmental conditions.

How pollutants and nutrients are transformed during their travel through the hyporheic zone is still unanswered (Peralta-Maraver et al., 2018). The uncertainties in the efficiency of the RZs in buffering effects of croplands are also related to the fragmentation of the landscape, since small changes in vegetation cover or machinery routes in an agricultural catchment can strongly influence hydrological pathways (Leal et al., 2016). Weller and Baker (2014) used models to predict the stream nitrate concentration and annual streamflow to estimate nitrate loads and found that RZs removed $21.5 \%$ of the nitrate loads released by the croplands, which would have increased to $53.3 \%$ in case the gaps in the riparian width that caused fragmentation of the riparian vegetation were restored. Although the riparian width is widely used as a measure to protect streams, Tiwari et al. (2016) have argued that this approach has been criticized for ignoring the spatial heterogeneity of biogeochemical processes and biodiversity in RZs debates, and that by using hydrologically adapted site-specific riparian buffers, landowners can maintain site specific efficient RZs.

To address these concerns, further studies on the efficiency of RZs using long-term datasets are recommended. As our findings show, the groundwater often exhibited nutrient concentrations higher than the streamflow, i.e., baseflow and stormflow, and DIC and Ca concentrations in the groundwater were also higher than overland flow in the $R Z$. We highlight that the magnitude of agricultural influences on streamflow water quality under baseflow conditions due to the contamination of groundwater is uncertain. Another uncertainty is the portion of the active root zone of the $R Z$ that 
provides a nutrient uptake significant enough to protect the soil and water. To that end, the soil-plant-atmosphere continuum needs to be addressed in a more integrated manner in future research. This should consider the effects that interflow and groundwater have on the streamflow quality by using field measurements and reactive transport modelling, as well as the ecological functioning of the hyporheic zone in Cerrado soils and the role that root uptake systems play in the groundwater quality, which are known to be complex in the Cerrado (Canadell et al., 1996).

\subsection{Conclusions}

We assessed the characteristics of the vegetation, soil and water of a cropland dominated catchment with a riparian zone in an agro-industrial area in the Cerrado on the Amazon Agricultural Frontier. Our study showed that the riparian zone sustains ecosystem services by providing an intense synergy between the plant biodiversity and soil and water quality. Among our findings, we highlight the following:

- In the riparian zone, we identified a high plant species diversity that ecologically function as pioneers, by improving and recovering altered environments in the Amazon agricultural frontier, especially in the Cerrado;

- The soil chemistry in the riparian zone maintains the major Cerrado soil characteristics (e.g., low $\mathrm{pH}$ and nutrients content), which facilitate the conservation of the native species. We identified that not only the soil chemical properties were conserved in the riparian zone in contrast to its surrounding cropland area, but also soil hydro-physical properties, such as bulk density and porosity were significantly different, which are important in maintaining natural water fluxes that are directly linked to buffering effects of the riparian zone;

- The maintenance of soil hydro-physical properties in riparian zones provides important ecosystem services since this is directly connected to water dynamics that flow to the stream. In this respect, we found the overland flow water from the cropland with the highest water nutrient concentrations, mostly related to inorganic carbon and fertilizers. We observed that these concentrations became lower as the water fluxes were closer to the stream, which were areas under higher influence of the riparian zone ecosystem. 


\section{Acknowledgements}

This research was feasible thanks to the support of the Bundesministerin für Bildung und Forschung (BMBF) through a grant to the CarBioCial project (support code: 01LL0902A). The authors also acknowledge the Fundação de Amparo à Pesquisa do Estado de Mato Grosso (FAPEMAT; support code: 335908/2012), the Brazilian National Council for Scientific and Technological Development (CNPq; support code: 481990/2013-5) and CAPES; the collaboration of field site host (Fazenda Santa Luzia); J. Grotheer, P. Voigt and A. Södje for technical support; and Jonas Macedo for field assistance. 


\section{Conclusions and outlook}

In this thesis, many approaches over several temporal and spatial scales were used to assess the impacts of land use and land cover change on hydrology, hydrochemistry, soil hydro-physical properties and vegetation in the Amazon and Cerrado biomes. By applying a top-down approach, large-scale analyses (macrocatchments) were conducted and, consequently, refined with studies on small scales (micro-catchments). The results were obtained using state-of-the-art methods including hydrological modelling, remote sensing techniques, high-temporal-resolution analyses, and ecosystem integrated assessments (soil-plant-water relationships). To that end, the study was supported by extensive field data collection in addition to laboratory and computational analysis. To the best of my knowledge, up to date, no published study has investigated both Amazon and Cerrado biomes using such different scales and methods in an integrated manner.

The macro-scale analyses (chapters 2 and 3) showed that land use and land cover change alters water quantity of large rivers in the Amazon and Cerrado biomes. These changes are more pronounced as an increase in the low flows, which are mainly maintained by the streams under baseflow dominant condition. Chapter 3 introduced the small-scale analysis in this thesis and showed that, although the magnitude of land use and land cover impact on water quantity and quality is known to be scaledependent, some changes are detectable in both small and large rivers in the Amazon biome.

The hydrological and soil analyses in small scale catchments (chapters 4 and 5) showed that land cover and catchment physiographic parameters play a substantial role in the hydrological responses of small catchments in the Amazon and Cerrado biomes, changing the water balance due to the conversion of native vegetation to pastures. Moreover, this land cover and land use conversion caused significant soil hydro-physical degradation (e.g., increased bulk density and reduced soil porosity). While an increase in the streamflow during baseflow conditions was observed in both biomes, an increase in peak flows was observed only in the pasture catchment of the 
Amazon biome. This is attributed to the decreased hydraulic conductivity of the topsoil, which was exceeded by the rainfall intensities, causing an increase in surface runoff and, consequently, greater peak flows. Additionally, the conversion of native vegetation to pastures reduced the evapotranspiration from the catchments in both biomes, which explained the increase in the baseflow due to the natural water balance of these areas.

The analysis of the role of stream discharge on carbon and nutrient dynamics and fluxes (chapter 6) showed how the conversion of forest and cerrado land covers to pastures changed hydrochemical fluxes. Stream carbon and nutrient concentrations were significantly higher in pasture catchments. These higher carbon and nutrient concentrations have further implications for carbon and nutrient fluxes as streamflow increases take place, as observed in chapters 4 and 5 . In this context, the stormflow has an essential role as a rapid hydrological pathway for carbon and nutrient losses, especially in areas where infiltration capacity rates are exceeded by the rainfall intensities, as observed in the pasture catchment in the Amazon biome.

By assessing vegetation biodiversity, soil hydro-physical and chemical characteristics, and water quality of a riparian zone in an agro-industrial catchment in the Cerrado biome (chapter 7), it was possible to observe that the riparian zone is providing ecosystem services and maintaining plant biodiversity, soil properties and water quality in the areas close to the stream. The riparian zone provides a strong synergy between the plants and soil, which has direct implications on water quality. In this area, it was identified that the majority of plants are pioneer plant species, which improve and recover altered environments. The soil chemistry in the riparian zone maintains the Cerrado soil characteristics (e.g., low pH and nutrients content), which facilitates the conservation of the native species. It was observed that not only were the soil chemical properties significantly different between the riparian zone and its surrounding cropland area, but the soil hydro-physical properties, such as bulk density, porosity, and hydraulic conductivity, were different as well. The maintenance of soil hydro-physical properties in riparian zones is a valuable ecosystem service since this is directly connected to dynamics (quantity and quality) of the water that flows to the stream. The overflow water from the cropland showed the highest water nutrient 
concentrations, mostly related to inorganic carbon and fertilizer applications. These nutrient concentrations became lower closer to the stream, showing the influence of the riparian zone ecosystem.

This study shows a chain reaction caused by the land use and land cover change that causes changes in the environment. The removal of native vegetation and the change of land use practices cause direct alterations in the soil characteristics. These changes subsequently alter the water, carbon and nutrient balances. Despite recent findings concluding that no-till agricultural practices in this region associated with high soil $\mathrm{P}$ fixation capacity of the soils protect streams from the impacts of land use and land cover change (Neill et al., 2017), more studies are crucial for the understanding of the role of riparian zones as important buffer systems influencing the water balance and reducing eutrophication in surface waters (Hattermann et al., 2006).

While this study contributes to the understanding of the hydrological and hydrochemical fluxes, as well as soil degradation and ecosystem services in these biomes, long-term measurements including quantifying changes in groundwater storage are required. The great baseflow contribution to the streamflow, highlighted in chapters 2, 3, 4, 5 and 6 , shows the importance of the groundwater in the water balance of these catchments. To that end, it is recommended that more empirical studies be undertaken to assess the manner in which the deforestation in the Amazon and Cerrado biomes affects the water balance, especially regarding the groundwater flow mechanisms and deep seepage. 


\section{References}

Aber JD, Magill A, Mcnulty SG, Boone RD, Nadelhoffer KJ, Downs M, Hallett R. 1995. Forest biogeochemistry and primary production altered by nitrogen saturation. Water, Air, \& Soil Pollution 85 (3): 1665-1670. DOI: 10.1007/BF00477219

Aber JD, Nadelhoffer KJ, Steudler P, Melillo JM. 1989. Nitrogen Saturation in Northern Forest EcosystemsExcess nitrogen from fossil fuel combustion may stress the biosphere. BioScience 39 (6): 378-386 DOI: 10.2307/1311067

Addy KL, Gold AJ, Groffman PM, Jacinthe PA. 1999. Ground Water Nitrate Removal in Subsoil of Forested and Mowed Riparian Buffer Zones. Journal of Environment Quality 28 (May): 962 DOI: 10.2134/jeq1999.00472425002800030029x

Aguiar TR, Bortolozo FR, Hansel FA, Rasera K, Ferreira MT. 2015. Riparian buffer zones as pesticide filters of no-till crops. Environmental Science and Pollution Research 22 (14): 10618-10626 DOI: 10.1007/s11356-015-4281-5

Aguiar TR, Rasera K, Parron LMM, Brito AGG, Ferreira MTT, Aguiar Jr. TR, Rasera K, Parron LMM, Brito AGG, Ferreira MTT. 2015. Nutrient removal effectiveness by riparian buffer zones in rural temperate watersheds: The impact of no-till crops practices. Agricultural Water Management 149: 7480 DOI: $10.1016 /$ j.agwat.2014.10.031

Alegre JC, Cassel DK. 1996. Dynamics of soil physical properties under alternative systems to slashand-burn. Agric. Ecosyst. Environ. 58 (1), 39-48.

Alencar DBS, Silva CL, Oliveira CAS. 2006. Influência da precipitação no escoamento superficial em uma microbacia hidrográfica do Distrito Federal. Engenharia Agrícola 26 (1): 103-112 DOI: 10.1590/S0100-69162006000100012

Alexander RB, Smith RA, Schwarz GE. 2000. Effect of stream channel size on the delivery of nitrogen to the Gulf of Mexico. Nature 403 (6771): 758-761. DOI: 10.1038/35001562

Alho CJR. 2012. Importância da biodiversidade para a saúde humana: uma perspectiva ecológica. Estudos Avançados 26 (74): 151-166. DOI: 10.1590/S0103-40142012000100011

Allen R, Irmak A, Trezza R, Hendrickx JMH, Bastiaanssen W, Kjaersgaard J. 2011. Satellite-based ET estimation in agriculture using SEBAL and METRIC. Hydrological Processes 25 (26): 4011-4027 DOI: 10.1002/hyp.8408

Allen RG, Pereira LS, Raes D, Smith M. 1998. Crop evapotranspiration: Guidelines for computing crop requirements. Irrigation and Drainage Paper No. 56, FAO (56): 300. DOI: 10.1016/j.eja.2010.12.001

Allen RG, Tasumi M, Trezza R, Morse A, Trezza R, Wright JL, Bastiaanssen W, Kramber W, Lorite I, Robison CW. 2007. Satellite-Based Energy Balance for Mapping Evapotranspiration with Internalized Calibration (METRIC) - Model. Journal of Irrigation and Drainage Engineering 133 (4): 380-394 DOI: 10.1061/(ASCE)0733-9437(2007)133:4(380)

Alvarenga LA, Mello CR de, Colombo A, Cuartas LA. 2017. Hydrologic Impacts Due To the Changes in Riparian Buffer in a Headwater Watershed. Cerne 23 (1): 95-102 DOI: $10.1590 / 01047760201723012205$

Amoozegar A. 1989. A compact, constant-head permeameter for measuring saturated hydraulic conductivity of the vadose zone. Soil Science Society Of America Journal. 53: 1356-1361.

Andrade RG, de C. Teixeira AH, Sano EE, Leivas JF, de C. Victoria D, Nogueira SF. 2014. Pasture evapotranspiration as indicators of degradation in the Brazilian Savanna: a case study for Alto Tocantins watershed. Proceedings Volume 9239, Remote Sensing for Agriculture, Ecosystems, and Hydrology XVI; $92391 Z$ (2014), Event: SPIE Remote Sensing, 2014, Amsterdam, Netherlands. DOI: $10.1117 / 12.2067225$ 
Andreae MO, Acevedo OC, Araújo A, Artaxo P, Barbosa CGG, Barbosa HMJ, Brito J, Carbone S, Chi X, Cintra BBL, et al. 2015. The Amazon Tall Tower Observatory (ATTO): overview of pilot measurements on ecosystem ecology, meteorology, trace gases, and aerosols. Atmospheric Chemistry and Physics 15 (18): 10723-10776. DOI: 10.5194/acp-15-10723-2015

APG TAPG, Chase MW, Christenhusz MJM, Fay MF, Byng JW, Judd WS, Soltis DE, Mabberley DJ, Sennikov AN, Soltis PS, et al. 2016. An update of the Angiosperm Phylogeny Group classification for the orders and families of flowering plants: APG IV. Botanical Journal of the Linnean Society 181 (1): 1-20 DOI: 10.1111/boj.12385

Armenteras D, Rodríguez N, Retana J. 2013. Landscape Dynamics in Northwestern Amazonia: An Assessment of Pastures, Fire and Illicit Crops as Drivers of Tropical Deforestation (DQ Fuller, ed.). PLOS ONE 8 (1): e54310 DOI: 10.1371/journal.pone.0054310

Arnold JG, Moriasi DN, Gassman PW, Abbaspour KC, White MJ, Srinivasan R, Santhi C, Harmel RD, van Griensven A, Van Liew MW. 2012. SWAT: Model Use, Calibration, and Validation. Transactions of the ASABE 55 (4): 1491-1508 DOI: 10.13031/2013.42256

ASCE-EWRI. 2005. The ASCE standardized reference evapotranspiration equation. ASCE-EWRI Standardization of Reference Evapotranspiration Task Comm. Report. ASCE Bookstore.

Asner GP, Townsend AR, Bustamante MMC, Nardoto GB, Olander LP. 2004. Pasture degradation in the central Amazon: linking changes in carbon and nutrient cycling with remote sensing. Global Change Biology 10 (5): 844-862 DOI: 10.1111/j.1529-8817.2003.00766.x

ASTM. 2000. Standard Test Methods for Determining Sediment Concentration in Water Samples: D3977-97. West Conshohocken, PA.

Ataíde KRP, Baptista GM de M. 2015. Modelagem de determinação da evapotranspiração real para o bioma. Proceedings of XVII Simpósio Brasileiro de Sensoriamento Remoto - SBSR, João Pessoa-PB, Brazil, INPE (1): 6381-6388

Aubert D, Loumagne C, Oudin L. 2003. Sequential assimilation of soil moisture and stream flow data in a conceptual rainfall runoff model, Journal of. Hydrology, 280:145-161.

Avagyan A, Runkle BRK, Kutzbach L. 2014. Application of high-resolution spectral absorbance measurements to determine dissolved organic carbon concentration in remote areas. Journal of Hydrology 517: 435-446 DOI: 10.1016/j.jhydrol.2014.05.060

Awotwi A, Yeboah F, Kumi M. 2015. Assessing the impact of land cover changes on water balance components of White Volta Basin in West Africa. Water and Environment Journal 29 (2): 259-267 DOI: 10.1111/wej. 12100

Baker DB, Richards RP, Loftus TT, Kramer JW. 2004. A new flashiness index: characteristics and applications to midwestern rivers and streams. Journal of the American Water Resources Association 40 (2): 503-522 DOI: 10.1111/j.1752-1688.2004.tb01046.x

Ballester M. 2003. A remote sensing/GIS-based physical template to understand the biogeochemistry of the Ji-Paraná river basin (Western Amazônia). Remote Sensing of Environment 87 (4): 429-445 DOI: 10.1016/j.rse.2002.10.001

Barona E, Ramankutty N, Hyman G, Coomes OT. 2010. The role of pasture and soybean in deforestation of the Brazilian Amazon. Environmental Research Letters 5 (2): 024002 DOI: 10.1088/1748-9326/5/2/024002

Bass AM, Bird MI, Liddell MJ, Nelson PN. 2011. Fluvial dynamics of dissolved and particulate organic carbon during periodic discharge events in a steep tropical rainforest catchment. Limnology and Oceanography 56 (6): 2282-2292 DOI: 10.4319/lo.2011.56.6.2282

Bass AM, Munksgaard NC, Leblanc M, Tweed S, Bird MI. 2014. Contrasting carbon export dynamics of human impacted and pristine tropical catchments in response to a short-lived discharge event. Hydrological Processes 28 (4): 1835-1843 DOI: 10.1002/hyp.9716

Bastiaanssen WG. 2000. SEBAL-based sensible and latent heat fluxes in the irrigated Gediz Basin, Turkey. Journal of Hydrology 229 (1-2): 87-100 DOI: 10.1016/S0022-1694(99)00202-4 
Bastiaanssen WGM, Menenti M, Feddes RA, Holtslag AAM. 1998. A remote sensing surface energy balance algorithm for land (SEBAL). 1. Formulation. Journal of Hydrology 212-213: 198-212 DOI: 10.1016/S0022-1694(98)00253-4

Beuchle R, Grecchi RC, Shimabukuro YE, Seliger R, Eva HD, Sano E, Achard F. 2015. Land cover changes in the Brazilian Cerrado and Caatinga biomes from 1990 to 2010 based on a systematic remote sensing sampling approach. Applied Geography 58: 116-127 DOI: 10.1016/j.apgeog.2015.01.017

Bianchi CA, Haig SM. 2013. Deforestation trends of tropical dry forests in Central Brazil. Biotropica 45 (3): 395-400 DOI: 10.1111/btp.12010

Biggs TW, Dunne T, Domingues TF, Martinelli LA. 2002. Relative influence of natural watershed properties and human disturbance on stream solute concentrations in the southwestern Brazilian Amazon basin. Water Resources Research 38 (8): 25-1-25-16 DOI: 10.1029/2001WR000271

Biggs TW, Dunne T, Muraoka T. 2006. Transport of water, solutes and nutrients from a pasture hillslope, southwestern Brazilian Amazon. Hydrological Processes 20: 2527-2547 DOI: 10.1002/hyp.6214

Birkinshaw SJ, O'Donnell GM, Moore P, Kilsby CG, Fowler HJ, Berry PAM. 2010. Using satellite altimetry data to augment flow estimation techniques on the Mekong River. Hydrological Processes 24 (26): 3811-3825 DOI: 10.1002/hyp.7811

Birsan MV, Molnár P, Burlando P, Pfaundler M. 2005, Stream flow trends in Switzerland. J. Hydrol. 314(1-4), 312-329, DOI: 10.1016/j.jhydrol.2005.06.008.

Blaen PJ, Khamis K, Lloyd CEM, Bradley C, Hannah D, Krause S. 2016. Real-time monitoring of nutrients and dissolved organic matter in rivers: Capturing event dynamics, technological opportunities and future directions. Science of the Total Environment 569-570: 647-660 DOI: 10.1016/j.scitotenv.2016.06.116

Blake GR and Hartge KH. 1986. Bulk density, in Klute, A. (Ed.), Methods of Soil Analysis, Part I. Am. Soc. Agron., Madison, WI. pp. 363 -376.

Bleich ME, Mortati AF, André T, Piedade MTF. 2016. Structural Dynamics of Pristine Headwater Streams from Southern Brazilian Amazon. River Research and Applications 32 (3): 473-482 DOI: $10.1002 /$ rra.2875

Bleich ME, Mortati AF, André T, Teresa M, Piedade F. 2014. Riparian deforestation affects the structural dynamics of headwater streams in Southern Brazilian Amazonia Patterns and processes in streams are determined by ecological and hydrological connectivity [1-5], in. Tropical Conservation Science 7 (4): 657-676 Available at: http://tropicalconservationscience.mongabay.com/content/v7/TCS-2014Vol7(4)_657-676_Bleich.pdf

Bloomfield JP, Allen DJ, Griffiths KJ. 2009. Examining geological controls on baseflow index (BFI) using regression analysis: An illustration from the Thames Basin, UK. Journal of Hydrology 373 (1-2): 164176 DOI: $10.1016 /$ j.jhydrol.2009.04.025

Blume T, Zehe E and Bronstert A. 2007. Rainfall-runoff response, event-based runoff coefficients and hydrograph separation, Hydrological Sciences Journal, 52(5):843-862. http://dx.doi.org/10.1623/hysj.52.5.843.

Bobbink R, Hicks K, Galloway J, Spranger T, Alkemade R, Ashmore M, Bustamante M, Cinderby S, Davidson E, Dentener F, et al. 2010. Global assessment of nitrogen deposition effects on terrestrial plant diversity: A synthesis. Ecological Applications 20 (1): 30-59 DOI: 10.1890/08-1140.1

Bongiovanni R, Lowenberg-Deboer J. 2004. Precision Agriculture and Sustainability. Precision Agriculture 5 (4): 359-387 DOI: 10.1023/B:PRAG.0000040806.39604.aa

Bouchez J, Galy V, Hilton RG, Gaillardet J, Moreira-Turcq P, Pérez MA, France-Lanord C, Maurice L. 2014. Source, transport and fluxes of Amazon River particulate organic carbon: Insights from river sediment depth-profiles. Geochimica et Cosmochimica Acta 133: 280-298 DOI: 10.1016/j.gca.2014.02.032 
Boulain N, Cappelaere B, Séguis L, Favreau G, Gignoux J. 2009. Water balance and vegetation change in the Sahel: A case study at the watershed scale with an eco-hydrological model, Journal of Arid Environments., 73:1125-1135, DOI: 10.1016/j.jaridenv.2009.05.008

Bowler DE, Mant R, Orr H, Hannah DM, Pullin AS. 2012. What are the effects of wooded riparian zones on stream temperature? Environmental Evidence 1 (1): 3 DOI: 10.1186/2047-2382-1-3

Bramley RG V, Hill PA, Thorburn PJ, Kroon FJ, Panten K. 2008. Precision agriculture for improved environmental outcomes: Some Australian perspectives. Landbauforschung Volkenrode 58 (58): 161177

Brando PM, Coe MT, DeFries R, Azevedo AA. 2013. Ecology, economy and management of an agroindustrial frontier landscape in the southeast Amazon. Philosophical transactions of the Royal Society of London. Series B, Biological sciences 368 (1619): 20120152 DOI: 10.1098/rstb.2012.0152

Brannstrom C, Jepson W, Filippi AM, Redo D, Xu Z, Ganesh S. 2008. Land change in the Brazilian Savanna (Cerrado), 1986-2002: Comparative analysis and implications for land-use policy. Land Use Policy 25 (4): 579-595 DOI: 10.1016/j.landusepol.2007.11.008

Breitenbach SFM, Adkins JF, Meyer H, Marwan N, Kumar KK, Haug GH. 2010. Strong influence of water vapor source dynamics on stable isotopes in precipitation observed in Southern Meghalaya, NE India, Earth Planet. Sc. Letters., 292:212-220, DOI: 10.1016/j.epsl.2010.01.038.

Brooks TM, Mittermeier RA, Mittermeier CG, Da Fonseca GAB, Rylands AB, Konstant WR, Flick P, Pilgrim J, Oldfield S, Magin G, et al. 2002. Habitat Loss and Extinction in the Hotspots of Biodiversity. Conservation Biology 16 (4): 909-923 DOI: 10.1046/j.1523-1739.2002.00530.x

Brooks TM. 2006. Global Biodiversity Conservation Priorities. Science 313 (5783): 58-61 DOI: 10.1126/science.1127609

Brown AE, Zhang L, McMahon TA, Western AW, Vertessy RA. 2005. A review of paired catchment studies for determining changes in water yield resulting from alterations in vegetation. Journal of Hydrology 310 (1-4): 28-61 DOI: 10.1016/j.jhydrol.2004.12.010

Bruijnzeel LA. 2004. Hydrological functions of tropical forests: Not seeing the soil for the trees? Agriculture, Ecosystems and Environment 104: 185-228. DOI: 10.1016/j.agee.2004.01.015

Bruijnzeel LA. 2005. Tropical montane cloud forest: a unique hydrological case. In Forests, Water and People in the Humid Tropics, Bonell, M; Bruijnzeel LA (ed.). Cambridge Univ. Press: Cambridge, UK; 462-483.

Bruijnzeel LA, Mulligan M, Scatena FN. 2011. Hydrometeorology of tropical montane cloud forests: emerging patterns, Hydrological Processes, 25, 465-498.

Bruijnzeel LA. 2006. Hydrological impacts of converting tropical montane cloud forest to pasture, with initial reference to northern Costa Rica. Final Technical Report DFID-FRP Project no. R7991. Vrije Universiteit, Amsterdam, and Forestry Research Programme of the U.K. Department for International Development, London, $52 \mathrm{pp}$.

Buffington JM, Tonina D. 2009. Hyporheic Exchange in Mountain Rivers II: Effects of Channel Morphology on Mechanics, Scales, and Rates of Exchange. Geography Compass 3 (3): 1038-1062 DOI: 10.1111/j.1749-8198.2009.00225.x

Buol SW. 2009. Soils and agriculture in central-west and north Brazil. Scientia Agricola 66 (5): 697-707 DOI: 10.1590/S0103-90162009000500016

Burke W, Gabriels D and Bouma J. (Eds). 1986. Soil Structure Assessment. A. A. Balkema, Rotterdam. $93 \mathrm{pp}$.

Burn DH, Sharif M, Zhang K. 2010. Detection of trends in hydrological extremes for Canadian watersheds. Hydrological Processes 24 (13): 1781-1790 DOI: 10.1002/hyp.7625

Burn DH and Hag Elnur MA. 2002. Detection of hydrologic trends and variability. J. Hydrol. 255(1-4), 107-122, DOI: 10.1016/S0022-1694(01)00514-5. 
Burt TP, McDonnell JJ. 2015. Whither field hydrology? The need for discovery science and outrageous hydrological hypotheses. Water Resources Research 51 (8): 5919-5928 DOI: 10.1002/2014WR016839

Cadotte MW, Carscadden K, Mirotchnick N. 2011. Beyond species: functional diversity and the maintenance of ecological processes and services. Journal of Applied Ecology 48 (5): 1079-1087 DOI: 10.1111/j.1365-2664.2011.02048.x

Cak AD, Moran EF, Figueiredo RDO, Lu D, Li G, Hetrick S. 2015. Urbanization and small household agricultural land use choices in the Brazilian Amazon and the role for the water chemistry of small streams. Journal of Land Use Science 4248 (October): 1-19 DOI: 10.1080/1747423X.2015.1047909

Canadell J, Jackson RB, Ehleringer JB, Mooney HA, Sala OE, Schulze E-D. 1996. Maximum rooting depth of vegetation types at the global scale. Oecologia 108 (4): 583-595 DOI: 10.1007/BF00329030

Canal Rural. 2017. Governo promete completar asfaltamento da BR-163 Available at: http://www.canalrural.com.br/videos/rural-noticias/governo-promete-completar-asfaltamento-br-16378671 [Accessed 1 July 2017]

Cappelaere B, Descroix L, Lebel T, Boulain N, Ramier D, Laurent J-P, Favreau G, Boubkraoui S, Boucher M, Moussa IB, Chaffard V, Hiernaux P, Issoufou HBA, Le Breton E, Mamadou I, Nazoumou Y, Oï M, Ottlé C and Quantin G. 2009. The AMMA-CATCH experiment in the cultivated Sahelian area of south-west Niger - Investigating water cycle response to a fluctuating climate and changing environment. Journal of Hydrology, 375, 34-51, DOI: 10.1016/j.jhydrol.2009.06.021

Carter MR. 1988. Temporal variability of soil macroporosity in a fine sandy loam under mouldboard ploughing and direct drilling. Soil and Tillage Research 12 (1): 37-51 DOI: 10.1016/01671987(88)90054-2

Carvalho GO, Nepstad D, McGrath D, del Carmen Vera Diaz M, Santilli M, Barros AC. 2002. Frontier Expansion in the Amazon: Balancing Development and Sustainability. Environment: Science and Policy for Sustainable Development 44 (3): 34-44 DOI: 10.1080/00139150209605606

Carvalho JLN, Cerri CEP, Cerri CC, Feigl BJ, Píccolo MC, Godinho VP, Herpin U. 2007. Changes of chemical properties in an oxisol after clearing of native Cerrado vegetation for agricultural use in Vilhena, Rondonia State, Brazil. Soil and Tillage Research 96 (1-2): 95-102 DOI: 10.1016/j.still.2007.04.001

Chander G, Markham BL, Helder DL. 2009. Summary of current radiometric calibration coefficients for Landsat MSS, TM, ETM+, and EO-1 ALI sensors. Remote Sensing of Environment 113 (5): 893-903 DOI: $10.1016 / \mathrm{j}$. rse.2009.01.007

Chantigny MH. 2003. Dissolved and water-extractable organic matter in soils: a review on the influence of land use and management practices. Geoderma 113 (3-4): 357-380 DOI: 10.1016/S00167061(02)00370-1

Chaplot V, Walter C, Curmi P, Hollier-Larousse A. 2000. The use of auxiliary geophysical data to improve a soil-landscape model. Soil Science 165 (12): 961-970 DOI: 10.1097/00010694-20001200000006

Chappell NA, Tych W. 2012. Identifying step changes in single streamflow and evaporation records due to forest cover change. Hydrological Processes 26 (1): 100-116 DOI: 10.1002/hyp.8115

Chaussê TCC, dos Santos Brandão C, da Silva LP, Salamim Fonseca Spanghero PE, da Silva DML. 2016. Evaluation of nutrients and major ions in streams-implications of different timescale procedures. Environmental Monitoring and Assessment 188 (1): 38 DOI: 10.1007/s10661-015-50340

Christophersen N, Clair TA, Driscoll CT, Jeffries DS, Neal C, Semkin RG. 1994. Hydrochemical Studies. In Biogeochemistry of Small Catchments: A Tool for Environmental Research, Moldan B, Cerny J (eds). J. Wiley: Chichester, West Sussex, England; 285-297.

Clark JM, Lane SN, Chapman PJ, Adamson JK. 2007. Export of dissolved organic carbon from an upland peatland during storm events: Implications for flux estimates. Journal of Hydrology 347 (3-4): 438-447 DOI: 10.1016/j.jhydrol.2007.09.030 
Coe MT, Costa MH, Soares-Filho BS. 2009. The influence of historical and potential future deforestation on the stream flow of the Amazon River - Land surface processes and atmospheric feedbacks. Journal of Hydrology 369 (1-2): 165-174 DOI: 10.1016/j.jhydrol.2009.02.043

Coe MT, Marthews TR, Costa MH, Galbraith DR, Greenglass NL, Imbuzeiro HM a, Levine NM, Malhi Y, Moorcroft PR, Muza MN, et al. 2013. Deforestation and climate feedbacks threaten the ecological integrity of south-southeastern Amazonia. Philosophical transactions of the Royal Society of London. Series B, Biological sciences 368 (1619): 20120155 DOI: 10.1098/rstb.2012.0155

Cohn AS, Gil J, Berger T, Pellegrina H, Toledo C. 2016. Patterns and processes of pasture to crop conversion in Brazil: Evidence from Mato Grosso State. Land Use Policy 55: 108-120 DOI: 10.1016/j.landusepol.2016.03.005

Costa MH, Botta A, Cardille JA. 2003. Effects of large-scale changes in land cover on the discharge of the Tocantins River, Southeastern Amazonia. Journal of Hydrology 283 (1-4): 206-217 DOI: 10.1016/S0022-1694(03)00267-1

Couto EG, Stein A, Klamt E. 1997. Large area spatial variability of soil chemical properties in central Brazil. Agriculture Ecosystems \& Environment 66 (2): 139-152 DOI: 10.1016/S0167-8809(97)000765

Crossman J, Futter MN, Whitehead PG, Stainsby E, Baulch HM, Jin L, Oni SK, Wilby RL, Dillon PJ. 2014. Flow pathways and nutrient transport mechanisms drive hydrochemical sensitivity to climate change across catchments with different geology and topography. Hydrology and Earth System Sciences 18 (12): 5125-5148 DOI: 10.5194/hess-18-5125-2014

Cruz Ruggiero PG, Batalha MA, Pivello VR, Meirelles ST. 2002. Soil-vegetation relationships in cerrado (Brazilian savanna) and semideciduous forest, Southeastern Brazil. Plant Ecology 160 (1973): 1-16 DOI: 10.1023/A:1015819219386

Cuo L, Zhang Y, Gao Y, Hao Z, Cairang L. 2013. The impacts of climate change and land cover/use transition on the hydrology in the upper Yellow River Basin, China. Journal of Hydrology 502: 37-52 DOI: 10.1016/j.jhydrol.2013.08.003

Cuomo A, Guida D. 2016. Using hydro-chemograph analyses to reveal runoff generation processes in a Mediterranean catchment. Hydrological Processes 30 (24): 4462-4476 DOI: 10.1002/hyp.10935

da Rocha HR, Manzi AO, Cabral OM, Miller SD, Goulden ML, Saleska SR, R.-Coupe N, Wofsy SC, Borma LS, Artaxo P, et al. 2009. Patterns of water and heat flux across a biome gradient from tropical forest to savanna in Brazil. Journal of Geophysical Research 114: G00B12 DOI: 10.1029/2007JG000640

da Silva BB, Wilcox BP, da Silva V de PR, Montenegro SMGL, de Oliveira LMM. 2015. Changes to the energy budget and evapotranspiration following conversion of tropical savannas to agricultural lands in São Paulo State, Brazil. Ecohydrology 8 (7): 1272-1283 DOI: 10.1002/eco.1580

Da Silva NM, Van Raij B, De Carvalho LH, Bataglia OC, Kondo Jl. 1998. Efeitos do calcário e do gesso nas características químicas do solo e na cultura do algodão. Bragantia 56 (2): 389-401 DOI: 10.1590/S0006-87051997000200018

Daniels RB, Gilliam JW. 1996. Sediment and Chemical Load Reduction by Grass and Riparian Filters. Soil Science Society of America Journal 60: 246 DOI: 10.2136/sssaj1996.03615995006000010037x

Davidson EA, de Araújo AC, Artaxo P, Balch JK, Brown IF, Bustamante MMC, Coe MT, DeFries RS, Keller M, Longo M, et al. 2012. The Amazon basin in transition. Nature 481 (7381): 321-328 DOI: 10.1038 /nature 10717

de Moraes JM, Schuler AE, Dunne T, Figueiredo R de O, Victoria RL. 2006. Water storage and runoff processes in plinthic soils under forest and pasture in eastern Amazonia. Hydrological Processes 20 (12): 2509-2526 DOI: 10.1002/hyp.6213

De Oliveira OC, De Oliveira IP, Alves BJR, Urquiaga S, Boddey RM. 2004. Chemical and biological indicators of decline/degradation of Brachiaria pastures in the Brazilian Cerrado. Agriculture, Ecosystems and Environment 103 (2): 289-300 DOI: 10.1016/j.agee.2003.12.004 
De Oliveira-Filho AT. 1992. Floodplain 'murundus' of Central Brazil: evidence for the termite-origin hypothesis. Journal of Tropical Ecology 8 (1): 1-19 DOI: 10.1017/S0266467400006027

de Paula JD, Luizão FJ, Piedade MTF. 2016. The size distribution of organic carbon in headwater streams in the Amazon basin. Environmental Science and Pollution Research 23 (12): 11461-11470 DOI: 10.1007/s11356-016-6041-6

Décamps H, Naiman RJ. 1990. The Ecology and Management of Aquatic-Terrestrial Ecotones. CRC Press: Paris:Unesco; Park Ridge, N.J., USA.

Diab M, Merot P, Curmi P. 1988. Water Movement in a glossaqualf as measured by two tracers. Geoderma 43 (2-3): 143-161 DOI: 10.1016/0016-7061(88)90040-7

Dias LCP, Macedo MN, Costa MH, Coe MT, Neill C. 2015. Effects of land cover change on evapotranspiration and streamflow of small catchments in the Upper Xingu River Basin, Central Brazil. Journal of Hydrology: Regional Studies 4: 108-122 DOI: 10.1016/j.ejrh.2015.05.010

DIN ISO 11277:2002-08. 2002. Bodenbeschaffenheit - Bestimmung der Partikelgrößenverteilung in Mineralböden - Verfahren mittels Siebung und Sedimentation. ISO 11277: 1998/Cor.1:2002. Beuth Verlag, Berlin, Germany., Germany.

Do Vale I, Miranda IS, Mitja D, Grimaldi M, Nelson BW, Desjardins T, Costa LGS. 2015. Tree Regeneration Under Different Land-Use Mosaics in the Brazilian Amazon's "Arc of Deforestation". Environmental Management 56 (2): 342-354 DOI: 10.1007/s00267-015-0500-6

Domingos M, Klumpp A, Rinaldi MCS, Modesto IF, Klumpp G, Delitti WBC. 2003. Combined effects of air and soil pollution by fluoride emissions on Tibouchina pulchra Cogn., at Cubatao, SE Brazil, and their relation with aluminium. Plant and soil 249: 297-308

Dos Santos SN, Alleoni LRF. 2013. Reference values for heavy metals in soils of the Brazilian agricultural frontier in Southwestern Amazônia. Environmental Monitoring and Assessment 185 (7): 5737-5748 DOI: 10.1007/s10661-012-2980-7

Drewry JJ, Cameron KC, Buchan GD. 2008. Pasture yield and soil physical property responses to soil compaction from treading and grazing - A review. Australian Journal of Soil Research 46: 237-256 DOI: $10.1071 /$ SR07125

Driessen P, Deckers J. 2001. Lecture notes on the major soils of the world. Rome.

Durieux L. 2003. The impact of deforestation on cloud cover over the Amazon arc of deforestation. Remote Sensing of Environment 86 (1): 132-140 DOI: 10.1016/S0034-4257(03)00095-6

Eckhardt K. 2005. How to construct recursive digital filters for baseflow separation. Hydrological Processes 19 (2): 507-515 DOI: 10.1002/hyp.5675

Ehsanzadeh E, Ouarda TBMJ, Saley HM. 2011. A simultaneous analysis of gradual and abrupt changes in Canadian low stream flows. Hydrol. Processes 25(5), 727-739, DOI: 10.1002/hyp.7861.

Eiten G. 1972. The cerrado vegetation of Brazil. The Botanical Review 38 (2): 201-341 DOI: 10.1007/BF02859158

El-Khoury A, Seidou O, Lapen DR, Que Z, Mohammadian M, Sunohara M, Bahram D. 2015. Combined impacts of future climate and land use changes on discharge, nitrogen and phosphorus loads for a Canadian river basin. Journal of Environmental Management 151: 76-86 DOI: 10.1016/j.jenvman.2014.12.012

Elsebeer H, Newton BE, Dunne T, Moraes JM. 1999. Hydraulic conductivities of latosols under pasture, forest and teak in Rondonia, BRAZIL, Hydrological Processes 13: 1417-1422 DOI: 10.1002/(SICI)1099-1085(19990630)13:9<1417::AID-HYP816>3.0.CO;2-6

Elsenbeer H, Vertessy RA. 2000. Stormflow generation and flowpath characteristics in an Amazonian rainforest catchment. Hydrological Processes 14 (14): 2367-2381 DOI: 10.1002/10991085(20001015)14:14<2367::AID-HYP107>3.0.CO;2-H

Elsenbeer H. 2001. Hydrologic flowpaths in tropical rainforest soilscapes - a review. Hydrological Processes, 15: 1751-1759. DOI: http://dx.doi.org/10.1002/hyp.237. 
Elsenbeer H, Lack A. 1996. Hydrometric and hydrochemical evidence for fast flowpaths at La Cuenca, Western Amazonia. Journal of Hydrology. 180: 237-250.

EMBRAPA (Empresa Brasileira de Pesquisa Agropecuária) (1999) Sistema brasileiro de classificação de solos. Brasília, DF: Embrapa Produção de Informação. Rio de Janeiro: Embrapa Solos, 412.

EMBRAPA. 1997. Manual de Métodos de Análise de Solo. EMBRAPA-CNPS: Rio de Janeiro.

EMBRAPA. 2006. Sistema brasileiro de classificação de solos. EMBRAPA-SPI: Rio de Janeiro.

EMBRAPA. 2006. Sistema brasileiro de classificação de solos. EMBRAPA-SPI: Rio de Janeiro.

Eshleman KN. 2004. Hydrological consequences of land use change: A review of the state-of-science. In Ecosystems and Land Use Change 13-29. DOI: 10.1029/153GM03

Esterby SR. 1996. Review of methods for the detection and estimation of trends with emphasis on water quality applications. Hydrological Processes 10 (2): 127-149 DOI: 10.1002/(SICI)10991085(199602) 10:2<127::AID-HYP354>3.0.CO;2-8

Evans JS. 2014. An ArcGIS Toolbox for surface gradient and geomorphometric modeling, version 2.00 Available at: http://evansmurphy.wix.com/evansspatial [Accessed 15 May 2015]

Farrick KK, Branfireun BA. 2013. Left high and dry: a call to action for increased hydrological research in tropical dry forests. Hydrological Processes 3262 (27): 3254-3262 DOI: 10.1002/hyp.9935

Esterby SR. 1996. Review of methods for the detection and estimation of trends with emphasis on water quality applications. Hydrological Processes 10 (2): 127-149 DOI: 10.1002/(SICI)10991085(199602)10:2<127::AID-HYP354>3.0.CO;2-8

Fearnside PM. 2001. Soybean cultivation as a threat to the environment in Brazil. Environmental Conservation 28 DOI: 10.1017/S0376892901000030

Fearnside PM. 2007. Brazil's Cuiabá- Santarém (BR-163) Highway: The environmental cost of paving a soybean corridor through the Amazon. Environmental Management 39 (5): 601-614 DOI: 10.1007/s00267-006-0149-2

Fearnside PM. 2016. Brazil's Amazonian forest carbon: the key to Southern Amazonia's significance for global climate. Regional Environmental Change 18 (1): 1-15 DOI: 10.1007/s10113-016-1007-2

Felfili J. 1997. Dynamics of the natural regeneration in the Gama gallery forest in central Brazil. Forest Ecology and Management 91 (2-3): 235-245 DOI: 10.1016/S0378-1127(96)03862-5

Esterby SR. 1996. Review of methods for the detection and estimation of trends with emphasis on water quality applications. Hydrological Processes 10 (2): 127-149 DOI: 10.1002/(SICl)10991085(199602) 10:2<127::AID-HYP354>3.0.CO;2-8

Felfili JM, Silva Júnior MC. 1992. Floristic composition, phytosociology and comparison of cerrado and gallery forests at Fazenda Água Limpa, Federal District, Brazil. In Nature and Dynamics of ForestSavanna Boundaries, Furley, P. A.; Proctor, J.; Ratter JA (ed.).Chapman and Hall: London; 393-415.

Feng X, Faiia AM, Posmentier ES. 2009. Seasonality of isotopes in precipitation: A global perspective, Journal of Geophysical Research., 114, D08116 DOI:10.1029/2008JD011279, 2009.

Ferraz SFB, Ferraz KMPMB, Cassiano CC, Brancalion PHS, da Luz DTA, Azevedo TN, Tambosi LR, Metzger JP. 2014. How good are tropical forest patches for ecosystem services provisioning? Landscape Ecology 29 (2): 187-200 DOI: 10.1007/s10980-014-9988-z

Figueiredo CC De, Resck DVS, Carneiro MAC. 2010a. Labile and stable fractions of soil organic matter under management systems and native cerrado. Revista Brasileira de Ciência do Solo 34 (3): 907916 DOI: 10.1590/S0100-06832010000300032

Figueiredo RO, Markewitz D, Davidson EA, Schuler AE, Dos S. Watrin O, De Souza Silva PP. 2010b. Land-use effects on the chemical attributes of low-order streams in the eastern Amazon. Journal of Geophysical Research: Biogeosciences 115 (4): 1-14 DOI: 10.1029/2009JG001200

Fligner MA. 1984. A Note on Two-Sided Distribution-Free Treatment versus Control Multiple Comparisons. Journal of the American Statistical Association 79 (385): 208-211 DOI: 10.1080/01621459.1984.10477086 
Fligner MA. 1984. A Note on Two-Sided Distribution-Free Treatment versus Control Multiple Comparisons. Journal of the American Statistical Association 79 (385): 208-211 DOI: 10.1080/01621459.1984.10477086

Fonte SJ, Nesper M, Hegglin D, Velásquez JE, Ramirez B, Rao IM, Bernasconi SM, Bünemann EK, Frossard E, Oberson A. 2014. Pasture degradation impacts soil phosphorus storage via changes to aggregate-associated soil organic matter in highly weathered tropical soils. Soil Biology and Biochemistry 68: 150-157 DOI: 10.1016/j.soilbio.2013.09.025

Fu G, Barber ME, Chen S. 2010. Hydro-climatic variability and trends in Washington State for the last 50 years. Hydrological Processes 24 (7): 866-878 DOI: 10.1002/hyp.7527

Furley PA. 1999. The nature and diversity of neotropical savanna vegetation with particular reference to the Brazilian cerrados. Global Ecology and Biogeography 8 (3-4): 223-241 DOI: 10.1046/j.1466822X.1999.00142.x

Galford GL, Melillo J, Mustard JF, Cerri CEP, Cerri CC. 2010. The Amazon Frontier of Land-Use Change: Croplands and Consequences for Greenhouse Gas Emissions. Earth Interactions 14 (15): 1-24 DOI: 10.1175/2010EI327.1

Garrastazú MC, Mendonça SD, Horokoski TT, Cardoso DJ, Rosot MAD, Nimmo ER, Lacerda AEB. 2015. Carbon sequestration and riparian zones: Assessing the impacts of changing regulatory practices in Southern Brazil. Land Use Policy 42 (January): 329-339 DOI: 10.1016/j.landusepol.2014.08.003

Gee GW. 1986. Particle-size analysis. In Methods of Soil Analysis, Klute A (ed.).ASA and SSSA: Madison, WI; 383-411.

Germer S, Neill C, Krusche AV, Elsenbeer H. 2010. Influence of land-use change on near-surface hydrological processes: Undisturbed forest to pasture. Journal of Hydrology 380 (3-4): 473-480 DOI: 10.1016/j.jhydrol.2009.11.022

Germer S, Neill C, Vetter T, Chaves J, Krusche AV, Elsenbeer H. 2009. Implications of long-term landuse change for the hydrology and solute budgets of small catchments in Amazonia. Journal of Hydrology 364 (3-4): 349-363 DOI: 10.1016/j.jhydrol.2008.11.013

Gerold G. 2011. Wasserhaushalt in Regenwaldeinzugsgebieten - regionale Folgen von Landnutzungsänderung und "climate change“. In Geographie Für Eine Welt Im Wandel, Fassmann H, Glade T (eds).Vienna University Press bei V\&R unipress: Wien; 255-281.

Gerold G. 2017. Impacts of carbon-optimised land use management in Southern Amazonia - multidisciplinary perspectives: An Introduction. Erdkunde 71 (3): 171-175 DOI: 10.3112/erdkunde.2017.03.01

Gessler PE, Moore ID, McKenzie NJ, Ryan PJ. 1995. Soil-landscape modelling and spatial prediction of soil attributes. International journal of geographical information systems 9 (4): 421-432 DOI: 10.1080/02693799508902047

Gharibreza M, Raj JK, Yusoff I, Othman Z, Tahir WZWM, Ashraf MA. 2013. Land use changes and soil redistribution estimation using137Cs in the tropical Bera Lake catchment, Malaysia. Soil and Tillage Research 131: 1-10 DOI: 10.1016/j.still.2013.02.010

Ghimire CP, Bruijnzeel LA, Lubczynski MW, Bonell M. 2014. Negative trade-off between changes in vegetation water use and infiltration recovery after reforesting degraded pasture land in the Nepalese Lesser Himalaya. Hydrology and Earth System Sciences 18 (12): 4933-4949 DOI: 10.5194/hess-184933-2014

Giambelluca TW, Scholz FG, Bucci SJ, Meinzer FC, Goldstein G, Hoffmann WA, Franco AC, Buchert MP. 2009. Evapotranspiration and energy balance of Brazilian savannas with contrasting tree density. Agricultural and Forest Meteorology 149: 1365-1376 DOI: 10.1016/j.agrformet.2009.03.006

Gollnow F, Göpel J, deBarros Viana Hissa L, Schaldach R, Lakes T. 2017. Scenarios of land-use change in a deforestation corridor in the Brazilian Amazon: combining two scales of analysis. Regional Environmental Change 18 (1): 1-17 DOI: 10.1007/s10113-017-1129-1 
Gonzatto, R., 2014. Aplicação superficial de calcário: até onde migram e até quando persistem os efeitos no perfil do solo? PhD Thesis. Programa De Pós-Graduação Em Ciência Do Solo, Federal University of Santa Maria.

Goodale UM, Ashton MS, Berlyn GP, Gregoire TG, Singhakumara BMPP, Tennakoon KU. 2012. Disturbance and tropical pioneer species: Patterns of association across life history stages. Forest Ecology and Management 277 (August 2012): 54-66 DOI: 10.1016/j.foreco.2012.04.020

Goodland R, Pollard R. 1973. The Brazilian Cerrado Vegetation: A Fertility Gradient. Journal of Ecology 61 (1): 219-224 DOI: 10.2307/2258929

Goodland R. 1971. A physiognomic analysis of the Cerrado vegetation of Central Brazil. Journal of Ecology 59 (2): 411-419 DOI: 10.2307/2258321

Grace J, José JS, Meir P, Miranda HS, Montes RA. 2006. Productivity and carbon fluxes of tropical savannas. Journal of Biogeography 33 (3): 387-400 DOI: 10.1111/j.1365-2699.2005.01448.x

Greenwood KL, McKenzie BM. 2001. Grazing effects on soil physical properties and the consequences for pastures: a review. Australian Journal of Experimental Agriculture 41 (8): 1231-1250

Gregory SV, Swanson FJ, McKee WA, Cummins KW. 1991. An Ecosystem Perspective of Riparian Zones. BioScience 41 (8): 540-551 DOI: 10.2307/1311607

Groisman PY, Knight RW, Karl TR. 2001. Heavy precipitation and high stream flow in the contiguous United States: trends in the twentieth century. Bull. Am. Met. Soc., 82(2), 219-246.

Guimberteau M, Ciais P, Pablo Boisier J, Paula Dutra Aguiar A, Biemans H, De Deurwaerder H, Galbraith D, Kruijt B, Langerwisch F, Poveda G, et al. 2017. Impacts of future deforestation and climate change on the hydrology of the Amazon Basin: A multi-model analysis with a new set of land-cover change scenarios. Hydrology and Earth System Sciences 21 (3): 1455-1475 DOI: 10.5194/hess-211455-2017

Guswa AJ, Brauman KA, Brown C, Hamel P, Keeler BL, Sayre SS. 2014. Ecosystem services: Challenges and opportunities for hydrologic modeling to support decision making. Water Resources Research 50 (5): 4535-4544 DOI: 10.1002/2014WR015497

Guzha AC, Amorim RSS, Nóbrega RLB, Lamparter G, Kovacs K, Bertão N, Gerold G. 2014. Impacts of Land Cover and Climate Change on Hydrology and Hydrochemistry in Selected Catchments in Southern Amazonia: Preliminary Analysis and Results. In Interdisciplinary Analysis and Modeling of Carbon-Optimized Land Management Strategies for Southern Amazonia, Gerold G, Jungkunst HF, Wantzen KM, Schönenberg R, Amorim RSS, Couto E, Madari B, Hohnwald S (eds). Universitätsverlag Göttingen: Goettingen; 71-83.

Guzha AC, Nóbrega R, Kovacs K, Amorim RSS, Gerold G. 2013a. Quantifying impacts of agroindustrial expansion in Mato Grosso, Brazil, on watershed hydrology using the Soil and Water Assessment Tool (SWAT) model. In Proceedings of the 20th International Congress on Modelling and Simulation, Adelaide, Australia, 1-6 December1833-1839.

Guzha AC, Nobrega R, Santos CAG, Gerold G. 2013b. Investigating discharge and rainfall variability in an Amazonian watershed: Do any trends exist? In Proceedings of H01, IAHS-IAPSO-IASPEI Assembly, IAHS: Gothenburg, Sweden; 346-351.

Guzha AC, Nobrega RLB, Kovacs K, Rebola-Lichtenberg J, Amorim RSS, Gerold G. 2015. Characterizing rainfall-runoff signatures from micro-catchments with contrasting land cover characteristics in southern Amazonia. Hydrological Processes 29 (4): 508-521 DOI: 10.1002/hyp.10161

Gyawali S, Techato K, Yuangyai C, Musikavong C. 2013. Assessment of Relationship between Land uses of Riparian Zone and Water Quality of River for Sustainable Development of River Basin, A Case Study of U-Tapao River Basin, Thailand. Procedia Environmental Sciences 17: 291-297 DOI: 10.1016/j.proenv.2013.02.041

Halliday SJ, Skeffington R a., Wade AJ, Bowes MJ, Gozzard E, Newman JR, Loewenthal M, PalmerFelgate EJ, Jarvie HP. 2015. High-frequency water quality monitoring in an urban catchment: 
hydrochemical dynamics, primary production and implications for the Water Framework Directive. Hydrological Processes 3407 (March). DOI: 10.1002/hyp.10453

Halliday SJ, Wade AJ, Skeffington RA, Neal C, Reynolds B, Rowland P, Neal M, Norris D. 2012. An analysis of long-term trends, seasonality and short-term dynamics in water quality data from Plynlimon, Wales. Science of the Total Environment 434: 186-200 DOI: 10.1016/j.scitotenv.2011.10.052

Hamilton LS, Juvik JO, Scatena FN 1995. The Puerto Rico Tropical Cloud Forest Symposium: Introduction and Workshop Synthesis. In: Hamilton, L. S., J. O. Juvik \& F. N. Scatena (eds.): Tropical Montane Cloud Forest. Springer, New York, 1-23.

Hamza MA, Anderson WK. 2005. Soil compaction in cropping systems: A review of the nature, causes and possible solutions. Soil and Tillage Research 82: 121-145 DOI: 10.1016/j.still.2004.08.009

Haridasan M. 2000. Nutricao Mineral de Plantas Nativas do Cerrado. Revista Brasileira de Fisiologia Vegetal 12 (1): 54-64

Haridasan M. 2008. Nutritional adaptations of native plants of the cerrado biome in acid soils. 20 (3): 183-195

Hattermann FF, Krysanova V, Habeck A, Bronstert A. 2006. Integrating wetlands and riparian zones in river basin modelling. Ecological Modelling 199 (4): 379-392 DOI: 10.1016/j.ecolmodel.2005.06.012

Hayhoe SJ, Neill C, Porder S, Mchorney R, Lefebvre P, Coe MT, Elsenbeer H, Krusche A V. 2011. Conversion to soy on the Amazonian agricultural frontier increases streamflow without affecting stormflow dynamics. Global Change Biology 17 (5): 1821-1833 DOI: 10.1111/j.13652486.2011.02392.x

Herbst M, Diekkrüger B, Vereecken H. 2006. Geostatistical co-regionalization of soil hydraulic properties in a micro-scale catchment using terrain attributes. Geoderma 132 (1-2): 206-221 DOI: 10.1016/j.geoderma.2005.05.008

Herbst M, Diekkrüger B. 2002. The influence of the spatial structure of soil properties on water balance modeling in a microscale catchment. Physics and Chemistry of the Earth, Parts $A / B / C 27$ (9-10): 701710 DOI: 10.1016/S1474-7065(02)00054-2

Hodnett M.G, Oyama M.D, Tomasella J, Marques Filho O. 1995. Comparisons of long-term soil water storage behaviour under pasture and forest in three areas of Amazonia. In Amazonian Deforestation and Climate, Gash JHC, Nobre CA, Roberts JM, Victoria RL (eds). Wiley: Chichester; 57-77.

Hoffmann WA, da Silva ER, Machado GC, Bucci SJ, Scholz FG, Goldstein G, Meinzer FC. 2005. Seasonal leaf dynamics across a tree density gradient in a Brazilian savanna. Oecologia 145 (2): 306315 DOI: $10.1007 / \mathrm{s} 00442-005-0129-x$

Hope D, Palmer SM, Billett MF, Dawson JJC. 2004. Variations in dissolved CO2 and CH4 in a firstorder stream and catchment: an investigation of soil-stream linkages. Hydrological Processes 18 (17): 3255-3275 DOI: 10.1002/hyp.5657

Hughes FMR, Colston A, Mountford JO. 2005. Restoring riparian ecosystems: The challenge of accommodating variability and designing restoration trajectories. Ecology and Society 10 (1): 12 Available at: http://www.ecologyandsociety.org/vol10/iss1/art12/

Hunke P, Mueller EN, Schröder B, Zeilhofer P. 2015a. The Brazilian Cerrado: assessment of water and soil degradation in catchments under intensive agricultural use. Ecohydrology 8 (6): 1154-1180 DOI: 10.1002/eco.1573

Hunke P, Roller R, Zeilhofer P, Schröder B, Mueller EN, Nora E, Mueller N, Mueller EN. 2015b. Soil changes under different land-uses in the Cerrado of Mato Grosso, Brazil. Geoderma Regional 4 (2015): 31-43 DOI: 10.1016/j.geodrs.2014.12.001

Ingram HAP. 1983. Hydrology. In Ecosystems of the World 4A, Mires: Swamps, Bog, Fen \& Moor, General Studies, Gore AJP (ed.). Elsevier Scientific Publishing Company: Amsterdam; 67-158.

Iñiguez-Armijos C, Rausche S, Cueva A, Sánchez-Rodríguez A, Espinosa C, Breuer L. 2016. Shifts in leaf litter breakdown along a forest-pasture-urban gradient in Andean streams. Ecology and Evolution 6 (14): 4849-4865 DOI: 10.1002/ece3.2257 
IUSS Working Group WRB. 2015. World Reference Base for Soil Resources 2014, update 2015. International soil classification system for naming soils and creating legends for soil maps. Rome.

Jakeman AJ, Hornberger GM. 1993. How much complexity is warranted in a rainfall-runoff model? Water Resour. Res. 29(8), 2637-2649, DOI: 10.1029/93WR00877.

Jarvis A, Reuter HI, Nelson A, Guevara E. 2008. Hole-filled seamless SRTM data V4, International Centre for Tropical Agriculture (CIAT) Available at: http://srtm.csi.cgiar.org [Accessed 1 January 2015]

Jenrich M. 2011. Potential of precision conservation agriculture as a means of increasing productivity and incomes for smallholder farmers. Journal of Soil and Water Conservation 66: 171A-174A DOI: 10.2489/jswc.66.6.171A

Jenrich M. 2011. Potential of precision conservation agriculture as a means of increasing productivity and incomes for smallholder farmers. Journal of Soil and Water Conservation 66: 171A-174A DOI: 10.2489/jswc.66.6.171A

Jepson W, Brannstrom C, Filippi A. 2010. Access Regimes and Regional Land Change in the Brazilian Cerrado, 1972-2002. Annals of the Association of American Geographers 100 (1): 87-111 DOI: $10.1080 / 00045600903378960$

Jepson W. 2005. A disappearing biome? Reconsidering land-cover change in the Brazilian savanna. The Geographical Journal 171 (2): 99-111 DOI: 10.1111/j.1475-4959.2005.00153.x

Jipp PH, Nepstad DC, Cassel DK, Reis de Carvalho C. 1998. Deep soil moisture storage and transpiration in forests and pastures of seasonally-dry Amazonia. Climatic Change 39: 395-412.

Johnson MS, Lehmann J, Couto EG, Filho JPN, Riha SJ. 2006. DOC and DIC in Flowpaths of Amazonian Headwater Catchments with Hydrologically Contrasting Soils. Biogeochemistry 81 (1): 4557 DOI: 10.1007/s10533-006-9029-3

Jollymore A, Johnson MS, Hawthorne I. 2012. Submersible UV-Vis spectroscopy for quantifying streamwater organic carbon dynamics: implementation and challenges before and after forest harvest in a headwater stream. Sensors (Basel, Switzerland) 12 (4): 3798-813 DOI: 10.3390/s120403798

Jordan TE, Correll DL, Weller DE. 1997. Relating nutrient discharges from watersheds to land use and streamflow variability. Water Resources Research 33 (11): 2579-2590 DOI: 10.1029/97WR02005

Juhász CEP, Cooper M, Cursi PR, Ketzer AO, Toma RS. 2007. Savanna woodland soil micromorphology related to water retention. Scientia Agricola 64 (4): 344-354 DOI: 10.1590/S010390162007000400005

Jusys T. 2016. Fundamental causes and spatial heterogeneity of deforestation in Legal Amazon. Applied Geography 75 (October): 188-199 DOI: 10.1016/j.apgeog.2016.08.015

Kahya E, Kalayci S. 2004. Trend analysis of stream flow in Turkey. J. Hydrol. 289(1-4), 128-144, DOI: 10.1016/j.jhydrol.2003.11.006.

Kaiser HF. 1974. An index of factorial simplicity. Psychometrika 39 (1): 31-36 DOI: 10.1007/BF02291575

Kebede, S. and Travi, Y. 2011. Origin of the _180 and_2H composition of meteoric waters in Ethiopia, Quatern. Int., 257, DOI: 10.1016/j.quaint.2011.09.032

Kindler R, Siemens J, Kaiser K, Walmsley DC, Bernhofer C, Buchmann N, Cellier P, Eugster W, Gleixner G, Grũnwald T, et al. 2011. Dissolved carbon leaching from soil is a crucial component of the net ecosystem carbon balance. Global Change Biology 17 (2): 1167-1185 DOI: 10.1111/j.13652486.2010.02282.x

Kindsvater CE, Carter RWC. 1957. Discharge Characteristics of Rectangular Thin Plate Weirs. Proceedings of the American Society of Civil Engineers, Journal of the Hydraulics Division 83 (HY6): 1453/1-1453/36.

King JR, Jackson D a. 1999. Variable selection in large environmental data sets using principal components analysis. Environmetrics 10 (June 1998): 67-77 DOI: 10.1002/(SICl)1099095X(199901/02)10:1<67::AID-ENV336>3.0.CO;2-0 
Kirchner JW, Neal C. 2013. Universal fractal scaling in stream chemistry and its implications for solute transport and water quality trend detection. Proceedings of the National Academy of Sciences 110 (30): 12213-12218 DOI: 10.1073/pnas.1304328110

Kirchner JW. 2003. A double paradox in catchment hydrology and geochemistry. Hydrological Processes 17 (4): 871-874 DOI: 10.1002/hyp.5108

Kirkby M, Callan J, Weyman D, Wood J. 1976. Measurement and modelling of dynamic contributing areas in very small catchments. 167. Leeds.

Klink CA, Machado RB. 2005. Conservation of the Brazilian Cerrado. Conservation Biology 19 (3): 707713 DOI: $10.1111 / \mathrm{j} .1523-1739.2005 .00702 . x$

Lahsen M, Nobre CA. 2007. Challenges of connecting international science and local level sustainability efforts: the case of the Large-Scale Biosphere-Atmosphere Experiment in Amazonia. Environmental Science \& Policy 10 (1): 62-74 DOI: 10.1016/j.envsci.2006.10.005

Lambin EF, Gibbs HK, Ferreira L, Grau R, Mayaux P, Meyfroidt P, Morton DC, Rudel TK, Gasparri I, Munger J. 2013. Estimating the world's potentially available cropland using a bottom-up approach. Global Environmental Change 23 (5): 892-901 DOI: 10.1016/j.gloenvcha.2013.05.005

Lamparter G, Nobrega RLB, Kovacs K, Amorim RSS, Gerold G. 2018. Modelling hydrological impacts of agricultural expansion in two macro-catchments in Southern Amazonia, Brazil. Regional Environmental Change 18 (1): 91-103 DOI: 10.1007/s10113-016-1015-2

Lapola DM, Martinelli LA, Peres CA, Ometto JPHBHB, Ferreira ME, Nobre CA, Aguiar APD, Bustamante MMCC, Cardoso MF, Costa MH, et al. 2013. Pervasive transition of the Brazilian landuse system. Nature Climate Change 4 (1): 27-35 DOI: 10.1038/nclimate2056

Lapola DM, Schaldach R, Alcamo J, Bondeau A, Msangi S, Priess JA, Silvestrini R, Soares-Filho BS. 2011. Impacts of Climate Change and the End of Deforestation on Land Use in the Brazilian Legal Amazon. Earth Interactions 15 (16): 1-29 DOI: 10.1175/2010EI333.1

Lathuillière MJ, Johnson MS, Donner SD. 2012. Water use by terrestrial ecosystems: temporal variability in rainforest and agricultural contributions to evapotranspiration in Mato Grosso, Brazil. Environmental Research Letters 7 (2): 024024 DOI: 10.1088/1748-9326/7/2/024024

Laurance WF. 2001. ENVIRONMENT: The Future of the Brazilian Amazon. Science 291 (5503): 438439 DOI: $10.1126 /$ science.291.5503.438

Leal CG, Pompeu PS, Gardner TA, Leitão RP, Hughes RM, Kaufmann PR, Zuanon J, de Paula FR, Ferraz SFB, Thomson JR, et al. 2016. Multi-scale assessment of human-induced changes to Amazonian instream habitats. Landscape Ecology 31 (8): 1725-1745 DOI: 10.1007/s10980-016-0358$x$

Lee JE, Johnson K, Fung I. 2009. Precipitation over South America during the Last Glacial Maximum: An analysis of the "amount effect" with a water isotope-enabled general circulation model, Geophysical Research Letters 36, L19701, DOI: 10.1029/2009GL039265

Li F, Ye YP, Song BW, Wang RS, Tao Y. 2014. Assessing the changes in land use and ecosystem services in Changzhou municipality, Peoples' Republic of China, 1991-2006. Ecological Indicators 42: 95-103 DOI: 10.1016/j.ecolind.2013.11.012

Lim KJ, Engel BA, Tang Z, Choi J, Kim K-S, Muthukrishnan S, Tripathy D. 2005. Automated Web GIS based hydrograph analysis tool, WHAT. Journal of the American Water Resources Association 41 (6): 1407-1416 DOI: 10.1111/j.1752-1688.2005.tb03808.x

Lim KJ, Park YS, Kim J, Shin Y-C, Kim NW, Kim SJ, Jeon J-H, Engel BA. 2010. Development of genetic algorithm-based optimization module in WHAT system for hydrograph analysis and model application. Computers \& Geosciences 36 (7): 936-944 DOI: 10.1016/j.cageo.2010.01.004

Lim KJ, Engel BA, Tang Z, Choi J, Kim K, Muthukrishnan S, Tripathy D. 2005. Automated Web GIS based Hydrograph Analysis Tool, WHAT. Journal of American Water Resources Association 41: 1407-1416. DOI: 10.1111/j.1752-1688.2005.tb03808.x 
Lim KJ, Park YS, Kim J, Shin Y-C, Kim NW, Kim SJ, Jeon J-H, Engel BA. 2010. Development of genetic algorithm-based optimization module in WHAT system for hydrograph analysis and model application. Computers \& Geosciences 36 (7): 936-944 DOI: 10.1016/j.cageo.2010.01.004

Lima JEFW. 2000. Determinação da evapotranspiração de uma bacia hidrográfica sob vegetação natural de cerrado, pelo método do balanço hídrico. Universidade de Brasília, Brasília, Brazil.

Lima LS, Coe MT, Soares Filho BS, Cuadra S V., Dias LCP, Costa MH, Lima LS, Rodrigues HO. 2014. Feedbacks between deforestation, climate, and hydrology in the Southwestern Amazon: Implications for the provision of ecosystem services. Landscape Ecology 29 (2): 261-274 DOI: 10.1007/s10980013-9962-1

Lin HS, Mclnnes KJ, Wilding LP, Hallmark CT. 1998. Macroporosity and initial moisture effects on infiltration rates in vertisols and vertic intergrades. Soil Science 163 (1): 2-8 DOI: 10.1097/00010694199801000-00002

Logsdon SD, Allmaras RR, Wu L, Swan JB, Randall GW. 1990. Macroporosity and Its Relation to Saturated Hydraulic Conductivity under Different Tillage Practices. Soil Science Society of America Journal 54 (4): 1096 DOI: 10.2136/sssaj1990.03615995005400040029x

Longo RM, Espíndola CR, Ribeiro Aĺ. 1999. Modificações Na Estabilidade De Agregados No Solo Decorrentes Da Introdução De Pastagens Em Áreas De Cerrado E Floresta Amazônica Introduction of Pasture Areas in "Cerrado " and Amazon Forest. Revista Brasileira de Engenharia Agrícola e Ambiental, 3 (3): 276-280 DOI: 10.1590/1807-1929/agriambi.v3n3p276-280

Lorenzo JS, Griffith JJ, Juchsch I, Souza AL, Reis MGF, Vale ABA. 1994. Fitossociologia para recuperar área de lavra. Ambiente - rev. CETESB tecnol. 8 (1): 26-33

Lowrance R, Sheridan JM. 2005. Surface runoff water quality in a managed three zone riparian buffer. Journal of environmental quality 34 (5): 1851-1859 DOI: 10.2134/jeq2004.0291

Lowrance R, Todd R, Fail, J, Hendrickson, O, Leonard R, Asmussen L. 1984. Riparian Forests as Nutrient Filters in Agricultural Watersheds. BioScience 34 (6): 374-377 DOI: 10.2307/1309729

Loyola RD, Oliveira-Santos LGR, Almeida-Neto M, Nogueira DM, Kubota U, Diniz-Filho JAF, Lewinsohn TM. 2009. Integrating economic costs and biological traits into global conservation priorities for carnivores. PLOS ONE 4 (8) DOI: 10.1371/journal.pone.0006807

Luke SH, Barclay H, Bidin K, Chey VK, Ewers RM, Foster WA, Nainar A, Pfeifer M, Reynolds G, Turner EC, et al. 2017. The effects of catchment and riparian forest quality on stream environmental conditions across a tropical rainforest and oil palm landscape in Malaysian Borneo. Ecohydrology 10 (4): e1827 DOI: $10.1002 /$ eco.1827

Luke SH, Slade EM, Gray CL, Annammala K V., Drewer J, Williamson J, Agama AL, Ationg M, Mitchell SL, Vairappan CS, et al. 2018. Riparian buffers in tropical agriculture: Scientific support, effectiveness and directions for policy (T Siqueira, ed.). Journal of Applied Ecology DOI: 10.1111/1365-2664.13280

Macedo MN, Coe MT, DeFries R, Uriarte M, Brando PM, Neill C, Walker WS. 2013. Land-use-driven stream warming in southeastern Amazonia. Philosophical transactions of the Royal Society of London. Series B, Biological sciences 368 (1619): 20120153 DOI: 10.1098/rstb.2012.0153

Mander Ü, Tournebize J. 2015. Riparian Buffer Zones: Functions and Dimensioning. In Reference Module in Earth Systems and Environmental Sciences Elsevier; 1-23. DOI: 10.1016/B978-0-12409548-9.09304-0

Marchman SC, Miwa M, Summer WB, Terrell S, Jones DG, Scarbrough SL, Jackson CR. 2015. Clearcutting and pine planting effects on nutrient concentrations and export in two mixed use headwater streams: Upper Coastal Plain, Southeastern USA. Hydrological Processes 29 (1): 13-28 DOI: 10.1002/hyp.10121

Marcuzzo FFN, Melo DCR, Rocha HM. 2011. Distribuição Espaço-Temporal e Sazonalidade das Chuvas no Estado do Mato Grosso. Revista Brasileira de Recursos Hídricos 16 (4): 157-167

Marimon BS, Felfili JM, Lima EDS, Duarte WMG, Marimon-Júnior BH. 2010. Environmental determinants for natural regeneration of gallery forest at the Cerrado/Amazonia boundaries in Brazil. Acta Amazonica 40 (1): 107-118 DOI: 10.1590/S0044-59672010000100014 
Marimon BS, Felfili JM, Lima ES. 2002. Floristics and Phytosociology of the Gallery Forest of the Bacaba Stream, Nova Xavantina, Mato Grosso, Brazil. Edinburgh Journal of Botany 59 (2): 303-318 DOI: $10.1017 /$ S0960428602000124

Marimon BS, Marimon-Junior BH, Mews HA, Jancoski HS, Franczak DD, Lima HS, Lenza E, Rossete AN, Moresco MC. 2012. Florística dos campos de murundus do Pantanal do Araguaia, Mato Grosso, Brasil. Acta Botanica Brasilica 26 (1): 181-196 DOI: 10.1590/S0102-33062012000100018

Markewitz D, Lamon EC, Bustamante MC, Chaves J, Figueiredo RO, Johnson MS, Krusche A, Neill C, Silva JSOO. 2011. Discharge-calcium concentration relationships in streams of the Amazon and Cerrado of Brazil: soil or land use controlled. Biogeochemistry 105 (1-3): 19-35 DOI: 10.1007/s10533011-9574-2

Markewitz D, Resende JCF, Parron L, Bustamante M, Klink CA, Figueiredo R de O, Davidson EA. 2006. Dissolved rainfall inputs and streamwater outputs in an undisturbed watershed on highly weathered soils in the Brazilian cerrado. Hydrological Processes 20 (12): 2615-2639 DOI: 10.1002/hyp.6219

Martínez LJ, Zinck JA, Martínez LJ, Zinck JA. 2004. Temporal variation of soil compaction and deterioration of soil quality in pasture areas of Colombian Amazonia. Soil and Tillage Research 75 (1): 3-18 DOI: 10.1016/j.still.2002.12.001

Massuel S, Cappelaere B, Favreau G, Leduc C, Lebel T, Vischel T. 2011. Integrated surface watergroundwater modelling in the context of increasing water reserves of a regional Sahelian aquifer. Hydrological Sciences Journal 56 (7): 1242-1264 DOI: 10.1080/02626667.2011.609171

Mazzetto AM, Feigl BJ, Cerri CEP, Cerri CC. 2016. Comparing how land use change impacts soil microbial catabolic respiration in Southwestern Amazon. Brazilian Journal of Microbiology 47 (1): 6372 DOI: 10.1016/j.bjm.2015.11.025

McGrath DA, Smith CK, Gholz HL, Oliveira FDA. 2001. Effects of land-use change on soil nutrient dynamics in Amaz??nia. Ecosystems 4 (7): 625-645 DOI: 10.1007/s10021-001-0033-0

Mcjannet D, Wallace J, Keen R, Hawdon A, Kemei J. 2012. The filtering capacity of a tropical riverine wetland: II. Sediment and nutrient balances. Hydrological Processes 26 (1): 53-72 DOI: 10.1002/hyp.8111

Meister S, Nobrega RLB, Rieger W, Wolf R, Gerold G. 2017. PROCESS-BASED MODELLING OF THE IMPACTS OF LAND USE CHANGE ON THE WATER BALANCE IN THE CERRADO BIOME (RIO DAS MORTES, BRAZIL). Erdkunde DOI: 10.3112/erdkunde.2017.03.06

Mendonça RC de, Felfili JM, Walter BM, Silva Júnior MC da, Rezende AV, Filgueiras T de S, Nogueira PE, Fagg CW. 2008. Flora Vascular do Bioma Cerrado, Checklist com 12356 espécies. Cerrado: ecologia e flora 2: 422-442

Mendonça RC, Felfili JM, Walter BM., Silva Junior MC, Rezende a. V., Filgueiras TS, Nogueira P. 1998. Flora vascular do bioma Cerrado. Cerrado: Ambiente e Flora. Embrapa, Planaltina: p.289-556 DOI: 10.1590/S0100-84042008000300005

Miles L, Newton AC, DeFries RS, Ravilious C, May I, Blyth S, Kapos V, Gordon JE. 2006. A global overview of the conservation status of tropical dry forests. Journal of Biogeography 33 (3): 491-505 DOI: 10.1111/j.1365-2699.2005.01424.x

Milly PCD, Dunne KA. Vecchia AV. 2005. Global pattern of trends in stream flow and water availability in a changing climate. Nature 438, 347-350, DOI: 10.1038/nature04312.

Mkhwanazi M, Chávez J, Andales A. 2015. SEBAL-A: A Remote Sensing ET Algorithm that Accounts for Advection with Limited Data. Part I: Development and Validation. Remote Sensing 7 (11): 1504615067 DOI: $10.3390 / \mathrm{rs} 71115046$

Molnár P, Ramírez JA. 2001, Recent trends in precipitation and streamflow in the Rio Puerco basin. J. Climate 14(10), 2317-2328, DOI: 10.1175/1520-0442(2001)014<2317:RTIPAS>2.0.CO;2.

Montanari R, Souza GSA, Pereira GT, Marques J, Siqueira DS, Siqueira GM. 2012. The use of scaled semivariograms to plan soil sampling in sugarcane fields. Precision Agriculture 13 (5): 542-552 DOI: $10.1007 / \mathrm{s} 11119-012-9265-6$ 
Moore ID, Grayson RB, Ladson AR. 1991. Digital terrain modelling: A review of hydrological, geomorphological, and biological applications. Hydrological Processes 5 (1): 3-30 DOI: 10.1002/hyp.3360050103

Moraes, J.M., Schuler, A.E., Dunne, T., Figueiredo, R.O., Victoria, R.L. 2006. Water storage and runoff processes in plinthic soils under forest and pasture in Eastern Amazonia. Hydrological Processes 20: 2509-2526. Doi:

Morais RF de, Silva ECS da, Metelo MRL, Morais FF de. 2013. Composição florística e estrutura da comunidade vegetal em diferentes fitofisionomias do Pantanal de Poconé, Mato Grosso. Rodriguésia 64 (4): 775-790 DOI: 10.1590/S2175-78602013000400008

Moreira A, Fageria NK. 2010. Liming influence on soil chemical properties, nutritional status and yield of alfalfa grown in acid soil. Revista Brasileira de Ciência do Solo 34 (4): 1231-1239 DOI: 10.1590/S0100-06832010000400022

Moreira-Turcq P, Seyler P, Guyot JL, Etcheber H. 2003. Exportation of organic carbon from the Amazon River and its main tributaries. Hydrological Processes 17 (7): 1329-1344 DOI: 10.1002/hyp.1287

Müller H, Rufin P, Griffiths P, Barros Siqueira AJ, Hostert P. 2015. Mining dense Landsat time series for separating cropland and pasture in a heterogeneous Brazilian savanna landscape. Remote Sensing of Environment 156: 490-499 DOI: 10.1016/j.rse.2014.10.014

Muñoz-Villers LE, McDonnell JJ. 2013. Land use change effects on runoff generation in a humid tropical montane cloud forest region. Hydrology and Earth System Sciences 17 (9): 3543-3560 DOI: 10.5194/hess-17-3543-2013

Myers N, Mittermeier RA, Mittermeier CG, da Fonseca GAB, Kent J. 2000. Biodiversity hotspots for conservation priorities. Nature 403 (6772): 853-858 DOI: 10.1038/35002501

Myers N. 2003. Biodiversity Hotspots Revisited. BioScience 53 (10): 916 DOI: 10.1641/00063568(2003)053[0916:BHR]2.0.CO;2

Nagy RC, Porder S, Neill C, Brando P, Quintino RM, Do Nascimento SASA. 2015. Structure and composition of altered riparian forests in an agricultural Amazonian landscape. Ecological Applications 25 (6): 1725-1738 DOI: 10.1890/14-1740.1

Naiman RJ, Decamps H, Pollock M. 1993. The Role of Riparian Corridors in Maintaining Regional Biodiversity. Ecological Applications 3 (2): 209-212 DOI: 10.2307/1941822

Neary DG. 2016. Long-term forest paired catchment studies: What do they tell us that landscape-level monitoring does not? Forests 7 (8): 1-15 DOI: 10.3390/f7080164

Neill C, Chaves JE, Biggs T, Deegan L a., Elsenbeer H, Figueiredo RO, Germer S, Johnson MS, Lehmann J, Markewitz D, et al. 2011. Runoff sources and land cover change in the Amazon: An endmember mixing analysis from small watersheds. Biogeochemistry 105 (1): 7-18 DOI: 10.1007/s10533011-9597-8

Neill C, Coe MT, Riskin SH, Krusche A V., Elsenbeer H, Macedo MN, McHorney R, Lefebvre P, Davidson EA, Scheffler R, et al. 2013. Watershed responses to Amazon soya bean cropland expansion and intensification. Philosophical Transactions of the Royal Society B: Biological Sciences 368 (1619): 20120425-20120425 DOI: 10.1098/rstb.2012.0425

Neill C, Deegan LA, Thomas SM, Cerri CC. 2001. Deforestation for pasture alters nitrogen and phosphorus in small Amazonian streams. Ecological Applications 11 (6): 1817-1828 DOI: 10.1890/1051-0761(2001)011[1817:DFPANA]2.0.CO;2

Neill C, Germer S, Neto G, Krusche A, Chaves J, Neill C, Germer S, Neto SG, Krusche A, Elsenbeer H. 2008. Land management impacts on runoff sources in small Amazon watersheds. Hydrological Processes 22 (12): 1766-1775 DOI: 10.1002/hyp.6803

Neill C, Jankowski K, Brando PM, Coe MT, Deegan LA, Macedo MN, Riskin SH, Porder S, Elsenbeer H, Krusche A V. 2017. Surprisingly Modest Water Quality Impacts From Expansion and Intensification of Large-Sscale Commercial Agriculture in the Brazilian Amazon-Cerrado Region. Tropical Conservation Science 10: 194008291772066 DOI: 10.1177/1940082917720669 
Neill C, Piccolo MC, Cerri CC, Steudler PA, Melillo JM. 2006. Soil solution nitrogen losses during clearing of lowland Amazon forest for pasture. Plant and Soil 281 (1-2): 233-245 DOI: 10.1007/s11104-005-4435-1

Nepstad D, McGrath D, Stickler C, Alencar A, Azevedo A, Swette B, Bezerra T, DiGiano M, Shimada J, Seroa da Motta R, et al. 2014. Slowing Amazon deforestation through public policy and interventions in beef and soy supply chains. Science 344 (6188): 1118-1123 DOI: 10.1126/science.1248525

Neu V, Neill C, Krusche A V. 2011. Gaseous and fluvial carbon export from an Amazon forest watershed. Biogeochemistry 105 (1-3): 133-147 DOI: 10.1007/s10533-011-9581-3

Neufeldt H, Resck DVS, Ayarza MA. 2002. Texture and land-use effects on soil organic matter in Cerrado Oxisols, Central Brazil. Geoderma 107 (3-4): 151-164 DOI: 10.1016/S0016-7061(01)001458

Newbold JD, Erman DC, Roby KB. 1980. Effects of Logging on Macroinvertebrates in Streams With and Without Buffer Strips. Canadian Journal of Fisheries and Aquatic Sciences 37 (7): 1076-1085 DOI: $10.1139 /$ f80-140

Niedzialek JM, Ogden FL. 2010. First-order catchment mass balance during the wet season in the Panama Canal Watershed, Journal of Hydrology, 462-463: 77-86, DOI:10.1016/j.jhydrol.2010.07.044.

Nobre CA, Sampaio G, Borma LS, Castilla-Rubio JC, Silva JS, Cardoso M. 2016. Land-use and climate change risks in the Amazon and the need of a novel sustainable development paradigm. Proceedings of the National Academy of Sciences of the United States of America 113 (39): 10759-10768 DOI: 10.1073/pnas. 1605516113

Nóbrega RLB, Guzha AC, Lamparter G, Amorim RSSS, Couto EG, Hughes HJ, Jungkunst HF, Gerold G, Programs I, Science E, et al. 2018a. Impacts of land-use and land-cover change on stream hydrochemistry in the Cerrado and Amazon biomes. Science of The Total Environment 635: 1-42 DOI: 10.1016/j.scitotenv.2018.03.356

Nóbrega RLB, Lamparter G, Hughes H, Guzha AC, Amorim RSS, Gerold G. 2018b. A multi-approach and multi-scale study on water quantity and quality changes in the Tapajós River basin, Amazon. Proceedings of the International Association of Hydrological Sciences 377: 3-7 DOI: 10.5194/piahs377-3-2018

Nóbrega RLB, Guzha AC, Torres GN, Kovacs K, Lamparter G, Amorim RSSS, Couto E, Gerold G. 2017. Effects of conversion of native cerrado vegetation to pasture on soil hydro-physical properties, evapotranspiration and streamflow on the Amazonian agricultural frontier (JA Jones, ed.). PLOS ONE 12 (6): e0179414 DOI: 10.1371/journal.pone.0179414

Ogden FL, Crouch TD, Stallard RF, Hall JS. 2013. Effect of land cover and use on dry season river runoff, runoff efficiency, and peak storm runoff in the seasonal tropics of Central Panama. Water Resources Research 49 (12): 8443-8462 DOI: 10.1002/2013WR013956

Oki T, Kanae S. 2006. Global Hydrological Cycles and World Water Resources. Science 313 (5790): 1068-1072 DOI: 10.1126/science. 1128845

Oliveira PS, Marquis RJ. 2002. The Cerrados of Brazil (PS Oliveira and RJ Marquis, eds). Columbia University Press: New York Chichester, West Sussex. DOI: 10.7312/oliv12042

Oliveira PTS, Nearing MA, Moran MS, Goodrich DC, Wendland E, Gupta H V. 2014. Trends in water balance components across the Brazilian Cerrado. Water Resources Research 50 (9): 7100-7114 DOI: 10.1002/2013WR015202

Oliveira PTS, Wendland E, Nearing M a., Scott RL, Rosolem R, da Rocha HR. 2015. The water balance components of undisturbed tropical woodlands in the Brazilian cerrado. Hydrology and Earth System Sciences 19 (6): 2899-2910 DOI: 10.5194/hess-19-2899-2015

Oliveira RS, Bezerra L, Davidson E a., Pinto F, Klink C a., Nepstad DC, Moreira a. 2005. Deep root function in soil water dynamics in cerrado savannas of central Brazil. Functional Ecology 19 (4): $574-$ 581 DOI: 10.1111/j.1365-2435.2005.01003.x

Oliveira-filho AT, Ratter JA. 1995. A study of the origin of central Brazilian Forests by the analysis of plant species distribution patterns. Edinb. J. Bot. 52 (2): 141-194 DOI: 10.1017/S0960428600000949 
Ometto JP, Aguiar APD, Martinelli LA. 2011. Amazon deforestation in Brazil: effects, drivers and challenges. Carbon Management 2 (5): 575-585 DOI: 10.4155/cmt.11.48

Oni SK, Futter MN, Molot LA, Dillon PJ. 2014. Adjacent catchments with similar patterns of land use and climate have markedly different dissolved organic carbon concentration and runoff dynamics. Hydrological Processes 28 (3): 1436-1449 DOI: 10.1002/hyp.9681

Osborne LL, Kovacic DA. 1995. 94Z/00035 Riparian vegetated buffer strips in water-quality restoration and stream management. Biological Conservation 71: 215 DOI: 10.1016/0006-3207(95)90078-0

Ouyang Y. 2005. Evaluation of river water quality monitoring stations by principal component analysis. Water Research 39: 2621-2635 DOI: 10.1016/j.watres.2005.04.024

Öztürk M, Copty NK, Saysel AK. 2013. Modeling the impact of land use change on the hydrology of a rural watershed. Journal of Hydrology 497: 97-109 DOI: 10.1016/j.jhydrol.2013.05.022

Paço TA, Pôças I, Cunha M, Silvestre JC, Santos FL, Paredes P, Pereira LS. 2014. Evapotranspiration and crop coefficients for a super intensive olive orchard. An application of SIMDualKc and METRIC models using ground and satellite observations. Journal of Hydrology 519: 2067-2080 DOI: 10.1016/j.jhydrol.2014.09.075

Parron LM, Bustamante MMC, Markewitz D. 2011. Fluxes of nitrogen and phosphorus in a gallery forest in the Cerrado of central Brazil. Biogeochemistry 105 (1-3): 89-104 DOI: 10.1007/s10533-010-9537z

Pavanato H, Melo-Santos G, Lima D, Portocarrero-Aya M, Paschoalini M, Mosquera F, Trujillo F, Meneses R, Marmontel M, Maretti C. 2016. Risks of dam construction for South American river dolphins: a case study of the Tapajós River. Endangered Species Research 31 (1): 47-60 DOI: 10.3354/esr00751

Penaluna BE, Olson DH, Flitcroft RL, Weber MA, Bellmore JR, Wondzell SM, Dunham JB, Johnson SL, Reeves GH. 2017. Aquatic biodiversity in forests: a weak link in ecosystem services resilience. Biodiversity and Conservation 26 (13): 3125-3155 DOI: 10.1007/s10531-016-1148-0

Peralta-Maraver I, Reiss J, Robertson AL. 2018. Interplay of hydrology, community ecology and pollutant attenuation in the hyporheic zone. Science of the Total Environment 610-611: 267-275 DOI: 10.1016/j.scitotenv.2017.08.036

Pereira P, Martha GB, Santana CA, Alves E. 2012. The development of Brazilian agriculture: future technological challenges and opportunities. Agriculture \& Food Security 1 (1): 4 DOI: 10.1186/20487010-1-4

Peterjohn WT, Correll DL. 1984. Nutrient Dynamics in an Agricultural Watershed: Observations on the Role of a Riparian Forest. Ecology 65 (5): 1466-1475 DOI: 10.2307/1939127

Pfeffer J, Champollion C, Favreau G, Cappelaere B, Hinderer J, Boucher M, Nazoumou Y, Oï M, Mouyen M, Henri C, Le Moigne N, Deroussi S, Demarty J, Boulain N, Benarrosh B, Robert O. 2013. Evaluating surface and subsurface water storage variations at small time and space scales from relative gravity measurements in semi-arid Niger. Water Resources Research. 49 (6): 3276-3291. DOI: 10.1002/wrcr.20235

Phillip MS. 1994. Measuring trees and forests. CABI Publishing: Wallingford, UK.

Pinheiro TF, Escada MISS, Valeriano DM, Hostert P, Gollnow F, Müller H. 2016. Forest degradation associated with logging frontier expansion in the Amazon: The BR-163 region in southwestern pará, Brazil. Earth Interactions 20 (17): 1-26 DOI: 10.1175/EI-D-15-0016.1

Pittaway PA, Melland AR, Antille DL, Marchuk S. 2018. Dissolved Organic Carbon in Leachate after Application of Granular and Liquid N-P-K Fertilizers to a Sugarcane Soil. Journal of Environment Quality 47 (3): 522 DOI: 10.2134/jeq2017.11.0433

Ponce VM, Cunha CN da. 1993. Vegetated Earthmounds in Tropical Savannas of Central Brazil: A Synthesis: With Special Reference to the Pantanal do Mato Grosso. Journal of Biogeography 20 (2): 219-225 DOI: 10.2307/2845673 
Potter C, Klooster S, Genovese V. 2012. Net primary production of terrestrial ecosystems from 2000 to 2009. Climatic Change 115 (2): 365-378 DOI: 10.1007/s10584-012-0460-2

Price JS, Maloney DA 1994. Hydrology of a patterned bog-fen complex in south-eastern Labrador, Canada. Nordic Hydrology 25: 313-330.

Quesada CA, Lloyd J, Anderson LO, Fyllas NM, Schwarz M, Czimczik Cl. 2011. Soils of Amazonia with particular reference to the RAINFOR sites. Biogeosciences 8 (6): 1415-1440 DOI: 10.5194/bg-8-14152011

R Core Team. 2017. R: A language and environment for statistical computing Available at: https://www.r-project.org/

Raaimakers D, Lambers H. 1996. Response to phosphorus supply of tropical tree seedlings: a comparison between a pioneer species Tapirira obtusa and a climax species Lecythis corrugata. New Phytologist 132 (1): 97-102 DOI: 10.1111/j.1469-8137.1996.tb04513.x

Ranalli AJ, Macalady DL. 2010. The importance of the riparian zone and in-stream processes in nitrate attenuation in undisturbed and agricultural watersheds - A review of the scientific literature. Journal of Hydrology 389 (3-4): 406-415 DOI: 10.1016/j.jhydrol.2010.05.045

Randhir TO, Ekness P. 2013. Water quality change and habitat potential in riparian ecosystems. Ecohydrology and Hydrobiology 13 (3): 192-200 DOI: 10.1016/j.ecohyd.2013.09.001

Ratter J a., Ribeiro JF, Bridgewater S, S. B, Bridgewater S. 1997. The Brazilian Cerrado Vegetation and Threats to its Biodiversity. Annals of Botany 80 (3): 223-230 DOI: 10.1006/anbo.1997.0469

Ravi S, D'Odorico P, Okin GS. 2007. Hydrologic and aeolian controls on vegetation patterns in arid landscapes. Geophysical Research Letters 34 (24): 1-5 DOI: 10.1029/2007GL031023

Recha JW, Lehmann J, Walter MT, Pell A, Verchot L, Johnson M. 2012. Stream Discharge in Tropical Headwater Catchments as a Result of Forest Clearing and Soil Degradation. Earth Interactions 16 (13): 1-18 DOI: 10.1175/2012EI000439.1

Recha JW, Lehmann J, Walter MT, Pell A, Verchot L, Johnson M. 2013. Stream water nutrient and organic carbon exports from tropical headwater catchments at a soil degradation gradient. Nutrient Cycling in Agroecosystems (3) DOI: 10.1007/s10705-013-9554-0

Resende ILDM, Araújo GM De, Oliveira APDA, Oliveira AP De, Ávila Júnior RS De. 2004. A comunidade vegetal e as características abióticas de um campo de murundu em Uberlândia, MG. Acta Botanica Brasilica 18 (1): 9-17 DOI: 10.1590/S0102-33062004000100002

Ribeiro JF, Walter BMT. 2008. AS PRINCIPAIS FITOFISIONOMIAS Ribeiro e Walter 2008.pdf: 151212.

Richards LA. 1947. Pressure-membrane apparatus, construction and use. Agricultural Engineering (28): 451-454.

Richardson JS, Naiman RJ, Swanson FJ, Hibbs DE. 2005. Riparian communities associated with pacific northwest headwater streams: assemblages, processes, and uniqueness. Journal of the American Water Resources Association 41 (4): 935-947 DOI: 10.1111/j.1752-1688.2005.tb03778.x

Richey JE, Ballester MV, Davidson EA, Johnson MS, Krusche A V. 2011. Land-Water interactions in the amazon. Biogeochemistry 105 (1-3): 1-5 DOI: 10.1007/s10533-011-9622-y

Richey JE, Wilhelm SR, Mcclain ME, Victoria RL, Melack JM, Araujo Lima C. 1997. Organic matter and nutrient dynamics in river corridors of the Amazon Basin and their response to anthropogenic change. Ciencia e Cultura (Sao Paulo) 49 (1-2): 98 DOI: 10.1029/20086M000728

Riskin SH, Neill C, Jankowski K, Krusche A V., McHorney R, Elsenbeer H, Macedo MN, Nunes D, Porder S. 2017. Solute and sediment export from Amazon forest and soybean headwater streams: Ecological Applications 27 (1): 193-207 DOI: 10.1002/eap.1428

Riskin SH, Porder S, Neill C, Figueira AMES, Tubbesing C, Mahowald N. 2013. The fate of phosphorus fertilizer in Amazon soya bean fields. Philosophical transactions of the Royal Society of London. Series B, Biological sciences 368 (1619): 20120154 DOI: 10.1098/rstb.2012.0154 
Roa-García MC, Brown S, Schreier H, Lavkulich LM. 2011. The role of land use and soils in regulating water flow in small headwater catchments of the Andes. Water Resources Research 47 (5): W05510 DOI: 10.1029/2010WR009582

Roa-Garcia, M. C. and Weiler, M. 2010. Integrated response and transit time distributions of watersheds by combining hydrograph separation and long-term transit time modeling, Hydrology and Earth System Sciences, 14, 1537-1549, DOI: 10.5194/hess-14-1537-2010

Roa-García MC, Brown S, Schreier H, Lavkulich LM. 2011. The role of land use and soils in regulating water flow in small headwater catchments of the Andes, Water Resources Research 47 (5): DOI: 10.1029/2010WR009582.

Rodriguez DA, Tomasella J, Linhares C. 2010. Is the forest conversion to pasture affecting the hydrological response of Amazonian catchments? Signals in the Ji-Paraná Basin. Hydrological Processes 24 (10): 1254-1269 DOI: 10.1002/hyp.7586

Rosenblüth B, Fuenzalida HA, Aceituno P. 1997. Recent temperature variations in Southern South America. Int. J. Climatol. 17(1), 67-85, DOI: 10.1002/(SICl)1097-0088(199701)17:1<67::AIDJOC120>3.0.CO;2-G.

Rowe BA. 1982. Effects of limestone on pasture yields and the $\mathrm{pH}$ of two krasnozems in north-western tasmania. Australian Journal of Experimental Agriculture 22 (115): 100-105 DOI: 10.1071/EA9820100

Rufin P, Müller H, Pflugmacher D, Hostert P. 2015. Land use intensity trajectories on Amazonian pastures derived from Landsat time series. International Journal of Applied Earth Observation and Geoinformation 41 (SEPTEMBER): 1-10 DOI: 10.1016/j.jag.2015.04.010

Ruhoff AL, Paz AR, Collischonn W, Aragao LEOC, Rocha HR, Malhi YS. 2012. A MODIS-Based Energy Balance to Estimate Evapotranspiration for Clear-Sky Days in Brazilian Tropical Savannas. Remote Sensing 4 (12): 703-725 DOI: 10.3390/rs4030703

Salemi LF, Groppo JD, Trevisan R, de Barros Ferraz SF, de Moraes JM, Martinelli LA. 2015. Nitrogen dynamics in hydrological flow paths of a small tropical pasture catchment. Catena 127: 250-257 DOI: 10.1016/j.catena.2015.01.009

Salemi LF, Groppo JD, Trevisan R, de Moraes JM, de Barros Ferraz SFF, Villani JP, Duarte-Neto PJ, Martinelli LA. 2013. Land-use change in the Atlantic rainforest region: Consequences for the hydrology of small catchments. Journal of Hydrology 499: 100-109 DOI: 10.1016/j.jhydrol.2013.06.049

Sánchez-Azofeifa GA, Quesada M, Rodríguez JP, Nassar JM, Stoner KE, Castillo A, Garvin T, Zent ELEL, Calvo-Alvarado JC, Kalacska MER, et al. 2005. Research priorities for neotropical dry forests. Biotropica 37 (4): 477-485 DOI: 10.1111/j.1744-7429.2005.00066.x

Sano EE, Ferreira LG, Asner GP, Steinke ET. 2007. Spatial and temporal probabilities of obtaining cloud-free Landsat images over the Brazilian tropical savanna. International Journal of Remote Sensing 28 (12): 2739-2752 DOI: 10.1080/01431160600981517

Sano EE, Rosa R, Luís J, Brito S, Ferreira G, Brito JLS, Ferreira LG. 2008. Notas Científicas Mapeamento semidetalhado do uso da terra do Bioma Cerrado. Pesquisa Agropecuária Brasileira 43 (1): 153-156 DOI: 10.1590/S0100-204X2008000100020

Santiago J, Da Silva MC, Lima LC, Silva Júnior MC da, Lima LC. 2005. Fitossociologia da regeneração arbórea na Mata de Galeria do Pitoco (IBGE-DF), seis anos após fogo acidental. Scientia Forestalis/Forest Sciences (67): 64-77

Santos JC, Leal IR, Almeida-Cortez JS, Fernandes GW, Tabarelli M. 2011. Caatinga: the scientific negligence experienced by a dry tropical forest. Tropical Conservation Science 4 (3): 276-286 Available at: http://tropicalconservationscience.mongabay.com/content/v4/11-09-25_276286_Santos_et_al.pdf

Santos CAG, Ideião SMA. 2006. Application of the wavelet transform for analysis of precipitation and runoff time series. In: Prediction in Ungauged Basins (ed. by M. Sivapalan et al.). IAHS Publ. 303, 431-439. IAHS Press, Wallingford, UK.

Santos CAG, Galvão CO, Trigo RM. 2003. Rainfall data analysis using wavelet transform. In: Hydrology in Mediterranean and Semi-arid Regions (ed. by E. Servat et al.). IAHS Publ. 278, 195-201. IAHS 
Press, Wallingford, UK.

Santos CAG, Galvão CO, Suzuki K, Trigo RM. 2001. Matsuyama city rainfall data analysis using wavelet transform. Ann. J. Hydraul. Engng, JSCE 45, 211-216.

Satinsky BM, Zielinski BL, Doherty M, Smith CB, Sharma S, Paul JH, Crump BC, Moran M. 2014. The Amazon continuum dataset: quantitative metagenomic and metatranscriptomic inventories of the Amazon River plume, June 2010. Microbiome 2 (1): 17 DOI: 10.1186/2049-2618-2-17

Scatena FN, Bruijnzeel LA, Bubb P, Das S. 2010. Setting the stage, in: Tropical Montane Cloud Forests: Science for Conservation and Management, edited by: Bruijnzeel LA, Scatena FN, Hamilton LS, Cambridge Univ. Press, UK, 3-13, 2010.

Scheffler R, Neill C, Krusche A V., Elsenbeer H. 2011. Soil hydraulic response to land-use change associated with the recent soybean expansion at the Amazon agricultural frontier. Agriculture, Ecosystems and Environment 144 (1): 281-289 DOI: 10.1016/j.agee.2011.08.016

Scheffler R, Neill C, Krusche A V., Elsenbeer H. 2011. Soil hydraulic response to land-use change associated with the recent soybean expansion at the Amazon agricultural frontier. Agriculture, Ecosystems and Environment 144 (1): 281-289 DOI: 10.1016/j.agee.2011.08.016

Scherer-Warren M, Rodrigues LN. 2013. Estimativa de Evapotranspiração Real por Sensoriamento Remoto: procedimento e aplicação em pivô central. Boletim de Pesquisa e Desenvolvimento (CPAC), Planaltina, DF: Embrapa Cerrados, 35 p.

Scherer-Warren M. 2012. Desmembramento de Estimativas de Evapotranspiração Obtidas por Sensoriamento Remoto nas Componentes de Evaporação e Transpiração Vegetal. Revista Brasileira de Geografia Física (02): 361-373

Schierhorn F, Gittelson AK, Müller D. 2016. How the Collapse of the Beef Sector in Post-Soviet Russia Displaced Competition for Ecosystem Services to the Brazilian Amazon. In Land Use Competition, Springer International Publishing: Cham; 165-182. DOI: 10.1007/978-3-319-33628-2_10

Schiesari L, Waichman A, Brock T, Adams C, Grillitsch B. 2013. Pesticide use and biodiversity conservation in the Amazonian agricultural frontier. Philosophical transactions of the Royal Society of London. Series B, Biological sciences 368 (1619): 20120378 DOI: 10.1098/rstb.2012.0378

Schneider R. 1963. Ground-Water Provinces of Brazil. Washington.

Schnorbus M, Alila Y. 2013. Peak flow regime changes following forest harvesting in a snow-dominated basin: Effects of harvest area, elevation, and channel connectivity, Water Resour. Res., 49, DOI: 10.1029/2012WR011901.

Schoenholtz SH, Van Miegroet H, Burger JA. 2000. A review of chemical and physical properties as indicators of forest soil quality: challenges and opportunities. Forest Ecology Management 138 (1-3): 335-356.

Séguis L, Cappelaere B, Milési G, Peugeot C, Massuel S, Favreau G. 2004. Simulated impacts of climate change and land-clearing on runoff from a small Sahelian catchment. Hydrological Processes 18 (17): 3401-3413 DOI: 10.1002/hyp.1503

Shen J. 1981. Discharge Characteristics of Triangular-notch Thin-plate Weirs. Geological Survey Water-Supply Paper 1617-B: 1-62

Sherson LR, Van Horn DJ, Gomez-Velez JD, Crossey LJ, Dahm CN. 2015. Nutrient dynamics in an alpine headwater stream: use of continuous water quality sensors to examine responses to wildfire and precipitation events. Hydrological Processes 3207 (February) DOI: 10.1002/hyp.10426

SIDRA/IBGE. 2012. Sistema IBGE de Recuperação Automática Available at: http://www.sidra.ibge.gov.br/ [Accessed 20 February 2008]

Silva CL, Oliveira CAS. 1999. Runoff measurement and prediction for a watershed under natural vegetation in central Brazil. Revista Brasileira de Ciência do Solo 23 (3): 695-701 DOI: 10.1590/S0100-06831999000300024 
Silva DML da, Ometto JPHB, Lobo G de A, Lima WDP, Scaranello MA, Mazzi E, Rocha HR da. 2007. Can land use changes alter carbon, nitrogen and major ion transport in subtropical Brazilian streams? Scientia Agricola 64 (4): 317-324 DOI: 10.1590/S0103-90162007000400002

Silva DML, Camargo PB, Mcdowell WH, Vieira I, Salomão MSMB, Martinelli LA. 2012. Influence of land use changes on water chemistry in streams in the State of São Paulo, southeast Brazil. Anais da Academia Brasileira de Ciências 84 (4): 919-930 DOI: 10.1590/S0001-37652012000400007

Silva JSO, da Bustamante MMC, Markewitz D, Krusche AV, Ferreira LG. 2011. Effects of land cover on chemical characteristics of streams in the Cerrado region of Brazil. Biogeochemistry 105 (1): 7588 DOI: 10.1007/s10533-010-9557-8

Silva LCR, Sternberg L, Haridasan M, Hoffmann WA, Miralles-Wilhelm F, Franco AC. 2008. Expansion of gallery forests into central Brazilian savannas. Global Change Biology 14 (9): 2108-2118 DOI: 10.1111/j.1365-2486.2008.01637.x

Silva ME, Pereira G, Rocha R. 2013. Increasing deforestation at the Arc of Deforestation in Brazil. In Geophysical Research Abstracts, Vienna; EGU2013-12011-1.

Silva-Júnior MC. 2005. Fitossociologia e Estrutura Diamétrica na Mata de Galeria do Pitoco, na Reserva Ecológica do IBGE, DF. Cerne 11: 147-158.

Skeffington RA, Halliday SJ, Wade AJ, Bowes MJ, Loewenthal M. 2015. Using high-frequency water quality data to assess sampling strategies for the EU Water Framework Directive. Hydrology and Earth System Sciences 19 (5): 2491-2504 DOI: 10.5194/hess-19-2491-2015

Skorupa ALA, Fay M, Zinn YL, Scheuber M. 2013. Assessing hydric soils in a gallery forest in the Brazilian Cerrado. Soil Use and Management 29 (1): 119-129 DOI: 10.1111/sum.12023

Smith J, Winograd M, Gallopin G, Pachico D. 1998. Dynamics of the agricultural frontier in the Amazon and savannas of Brazil: analyzing the impact of policy and technology. Environmental Modeling and Assessment 3 (1/2): 31-46 DOI: 10.1023/A:1019094218552

Smith KA, Jackson DR, Withers PJA. 2001. Nutrient losses by surface run-off following the application of organic manures to arable land. 2. Phosphorus. Environmental Pollution 112 (1): 53-60 DOI: 10.1016/S0269-7491(00)00098-1

Smith M, Conte P, Berns AE, Thomson JR, Cavagnaro TR. 2012. Spatial patterns of, and environmental controls on, soil properties at a riparian-paddock interface. Soil Biology and Biochemistry 49 (March 2012): 38-45 DOI: 10.1016/j.soilbio.2012.02.007

Soares-Filho B, Alencar A, Nepstad D, Cerqueira G, Del Carmen Vera Diaz M, Rivero S, Solórzano L, Voll E. 2004a. Simulating the response of land-cover changes to road paving and governance along a major Amazon highway: The Santarém-Cuiabá corridor. Global Change Biology 10 (5): 745-764 DOI: 10.1111/j.1529-8817.2003.00769.x

Soares-filho B, Rajão R, Macedo M, Carneiro A, Costa W, Coe M, Rodrigues H, Alencar A. 2014b. Cracking Brazil 's Forest Code. Science 344 (April): 363-364 DOI: 10.1126/science.124663

Soares-Filho BS, Nepstad DC, Curran L, Cerqueira GC, Garcia RA, Ramos CA, Voll E, McDonald A, Lefebvre $\mathrm{P}$, Schlesinger $\mathrm{P}$, et al. 2005. Cenários de desmatamento para a Amazônia. Estudos Avançados 19 (54): 137-152 DOI: 10.1590/S0103-40142005000200008

Soares-Filho BS, Nepstad DC, Curran LM, Cerqueira GC, Garcia RA, Ramos CA, Voll E, McDonald A, Lefebvre P, Schlesinger P. 2006. Modelling conservation in the Amazon basin. Nature 440 (7083): 520-523 DOI: 10.1038/nature04389

Soil Survey Staff 1999, Soil Taxonomy A basic system of soil classification for making and interpreting soil surveys; 2nd edition. Agricultural Handbook 436; Natural Resources Conservation Service, USDA, Washington DC, USA, pp. 869

Soil Survey Staff. 2015. Illustrated guide to soil taxonomy, version 2. Lincoln, Nebraska.

Souza-Filho PWM, de Souza EB, Silva Júnior RO, Nascimento WR, Versiani de Mendonça BR, Guimarães JTF, Dall'Agnol R, Siqueira JO. 2016. Four decades of land-cover, land-use and 
hydroclimatology changes in the Itacaiúnas River watershed, southeastern Amazon. Journal of Environmental Management 167: 175-184 DOI: 10.1016/j.jenvman.2015.11.039

Spera SA, Galford GL, Coe MT, Macedo MN, Mustard JF. 2016. Land-use change affects water recycling in Brazil's last agricultural frontier. Global Change Biology 22 (10): 3405-3413 DOI: $10.1111 / \mathrm{gcb} .13298$

Speratti A, Johnson M, Martins Sousa H, Nunes Torres G, Guimarães Couto E. 2017. Impact of Different Agricultural Waste Biochars on Maize Biomass and Soil Water Content in a Brazilian Cerrado Arenosol. Agronomy 7 (3): 49 DOI: 10.3390/agronomy7030049

Sprent Jl. 2001. Nodulation in legumes. Royal Botanic Gardens: Kew, UK.

Sternberg LDSL, Bucci S, Franco A, Goldstein G, Hoffman WA, Meinzer FC, Moreira MZ, Scholz F. 2005. Long range lateral root activity by neo-tropical savanna trees. Plant and Soil 270 (1): 169-178 DOI: 10.1007/s11104-004-1334-9

Stevens PA, Norris DA, Sparks TH, Hodgson AL. 1994. The impacts of atmospheric $n$ inputs on throughfall, soil and stream water interactions for different aged forest and moorland catchments in Wales. Water, Air, \& Soil Pollution 73 (1): 297-317 DOI: 10.1007/BF00477994

Stickler CM, Nepstad DC, Azevedo AA, McGrath DG, B PTRS. 2013. Defending public interests in private lands: compliance, costs and potential environmental consequences of the Brazilian Forest Code in Mato Grosso. Philosophical transactions of the Royal Society of London. Series B, Biological sciences 368 (1619): 20120160 DOI: 10.1098/rstb.2012.0160

Strassburg BBN, Brooks T, Feltran-Barbieri R, Iribarrem A, Crouzeilles R, Loyola R, Latawiec AE, Oliveira Filho FJB, Scaramuzza CA de M, Scarano FR, et al. 2017. Moment of truth for the Cerrado hotspot. Nature Ecology \& Evolution 1 (4): 0099 DOI: 10.1038/s41559-017-0099

Strey S, Boy J, Strey R, Weber O, Guggenberger G. 2016. Response of soil organic carbon to landuse change in central Brazil: a large-scale comparison of Ferralsols and Acrisols. Plant and Soil 408 (1-2): 327-342 DOI: 10.1007/s11104-016-2901-6

Strohmeier S, Knorr KH, Reichert M, Frei S, Fleckenstein JH, Peiffer S, Matzner E. 2013. Concentrations and fluxes of dissolved organic carbon in runoff from a forested catchment: Insights from high frequency measurements. Biogeosciences 10 (2): 905-916 DOI: 10.5194/bg-10-905-2013

Sun J, Tang C, Wu P, Strosnider WHJ, Han Z. 2013. Hydrogeochemical characteristics of streams with and without acid mine drainage impacts: A paired catchment study in karst geology, SW China. Journal of Hydrology 504: 115-124 DOI: 10.1016/j.jhydrol.2013.09.029

Suryatmojo H, Masamitsu F, Mizuyama T. 2013. Effects of elective logging methods on runoff characteristics in paired small headwater catchment. Procedia Environmental Sciences 17: 221 - 229.

Tang J-L, Zhang B, Gao C, Zepp H. 2008. Hydrological pathway and source area of nutrient losses identified by a multi-scale monitoring in an agricultural catchment. CATENA 72 (3): 374-385 DOI: 10.1016/j.catena.2007.07.004

Tardy Y, Bustillo V, Roquin C, Mortatti J, Victoria R. 2005. The Amazon. Bio-geochemistry applied to river basin management: Part I. Hydro-climatology, hydrograph separation, mass transfer balances, stable isotopes, and modelling. Applied Geochemistry 20 (9): 1746-1829 DOI: 10.1016/j.apgeochem.2005.06.001

Templer PH, Mack MC, III FSC, Christenson LM, Compton JE, Crook HD, Currie WS, Curtis CJ, Dail DB, D'Antonio CM. 2012. Sinks for nitrogen inputs in terrestrial ecosystems: a meta-analysis of $15 \mathrm{~N}$ tracer field studies. Ecology 93 (8): 1816-1829 DOI: 10.1890/11-1146.1

Teuling AJ. 2007. Soil moisture dynamics and land surface-atmosphere interaction. PhD Thesis, Wageningen University.

Thomas SM, Neill C, Deegan LA, Krusche AV., Ballester VM, Victoria RL. 2004. Influences of land use and stream size on particulate and dissolved materials in a small Amazonian stream network. Biogeochemistry 68: 135-151 DOI: 10.1023/B:BIOG.0000025734.66083.b7

Tinker PB, Nye PH. 2000. Solute movement in the rhizosphere. Oxford University Press: Oxford. 
Tiwari T, Lundström J, Kuglerová L, Laudon H, Öhman K, Ågren AM. 2016. Cost of riparian buffer zones: A comparison of hydrologically adapted site-specific riparian buffers with traditional fixed widths. Water Resources Research 52 (2): 1056-1069 DOI: 10.1002/2015WR018014

Tognetti S, Aylward B, Bruijnzeel LA. 2010. Assessment needs to support the development of arrangements for payments for ecosystem services from tropical montane cloud forests, in: Tropical Montane Cloud Forests. Science for Conservation and Management, edited by: Bruijnzeel, L. A., Scatena, F. N., and Hamilton, L. S., Cambridge Univ. Press, Cambridge, UK, 671-685.

Tollefson J. 2015. Stopping deforestation: Battle for the Amazon. Nature 520 (7545): 20-23 DOI: $10.1038 / 520020 a$

Tomasella J, Neill C, Figueiredo R, Nobre AD. 2009. Water and chemical budgets at the catchment scale including nutrient exports from intact forests and disturbed landscapes. In Geophysical Monograph Series 505-524. DOI: 10.1029/2008GM000727

Torrence C, Compo GP. 1998. A practical guide to wavelet analysis. Bull. Am. Met. Soc., 79(1), 61-78, DOI: 10.1175/1520-0477(1998)079<0061:APGTWA>2.0.CO;2.

Trancoso R, Tomasella J, Filho AC, Ferreira MT, Rodrigues DA, da Silva RC, Cuartas LA, Nascimento AHM, Nascimento TAM. 2007. Hydrological impacts of forest conversion to grassland in small catchments in Brazilian Amazon. In: 87th Conference on Hydrology, Texas, USA.

Troch PA, Lahmers T, Meira A, Mukherjee R, Pedersen JW, Roy T, Valdés-Pineda R. 2015. Catchment coevolution: A useful framework for improving predictions of hydrological change? Water Resources Research 51 (7): 4903-4922 DOI: 10.1002/2015WR017032

Uehara G, Gillman G. 1981. The Mineralogy, Chemistry, and Physics of Tropical Soils with VariableCharge Clays. West-View Press: Buolder, Colorado, Colorado.

Valle Junior RF, Varandas SGP, Pacheco FAL, Pereira VR, Santos CF, Cortes RMV, Sanches Fernandes LF. 2015. Impacts of land use conflicts on riverine ecosystems. Land Use Policy 43: 4862 DOI: 10.1016/j.landusepol.2014.10.015

Valle RF, Varandas SGP, Sanches Fernandes LF, Pacheco FAL. 2014. Groundwater quality in rural watersheds with environmental land use conflicts. Science of the Total Environment 493: 812-827 DOI: 10.1016/j.scitotenv.2014.06.068

Valpassos MAR, Cavalcante EGS, Cassiolato AMR, Alves MC. 2001. Effects of soil management systems on soil microbial activity, bulk density and chemical properties. Pesquisa Agropecuária Brasileira 36 (12): 1539-1545 DOI: 10.1590/S0100-204X2001001200011

van den Berg E, Chazdon R, Corrêa BS. 2012. Tree growth and death in a tropical gallery forest in Brazil: Understanding the relationships among size, growth, and survivorship for understory and canopy dominant species. Plant Ecology 213 (7): 1081-1092 DOI: 10.1007/s11258-012-0067-8

Vedovato LB, Fonseca MG, Arai E, Anderson LO, Aragão LEOC. 2016. The extent of 2014 forest fragmentation in the Brazilian Amazon. Regional Environmental Change 16 (8): 2485-2490 DOI: 10.1007/s10113-016-1067-3

Villela DM, Haridasan M. 1994. Response of the ground layer community of a cerrado vegetation in central Brazil to liming and irrigation. Plant and Soil 163 (1): 25-31 DOI: 10.1007/BF00033937

Vogel RM, Fennessey NM. 1994. Flow-Duration Curves. I: New Interpretation and Confidence Intervals. Journal of Water Resources Planning and Management 120 (4): 485-504 DOI: 10.1061/(ASCE)07339496(1994)120:4(485)

Vogt E, Braban CF, Dragosits U, Durand P, Sutton MA, Theobald MR, Rees RM, McDonald C, Murray S, Billett MF. 2015. Catchment land use effects on fluxes and concentrations of organic and inorganic nitrogen in streams. Agriculture, Ecosystems \& Environment 199 (12): 320-332 DOI: 10.1016/j.agee.2014.10.010

Voltz M, Goulard M. 1994. Spatial interpolation of soil moisture retention curves. Geoderma 62 (1-3): 109-123 DOI: 10.1016/0016-7061(94)90031-0 
Vose JM, Sun G, Ford CR, Bredemeier M, Otsuki K, Wei X, Zhang Z, Zhang L. 2011. Forest ecohydrological research in the 21st century: What are the critical needs? Ecohydrology 4 (2): 146158 DOI: $10.1002 /$ eco.193

Vourlitis GL, Hentz CS. 2016. Impacts of chronic N input on the carbon and nitrogen storage of a postfire Mediterranean-type shrubland. Journal of Geophysical Research: Biogeosciences 121 (2): 385-398 DOI: 10.1002/2015JG003220

Ward JV. 1989. The Four-Dimensional Nature of Lotic Ecosystems. Journal of the North American Benthological Society 8 (1): 2-8 DOI: 10.2307/1467397

Waterloo MJ, Oliveira SM, Drucker DP, Nobre AD, Cuartas LA, Hodnett MG, Langedijk I, Jans WWP, Tomasella J, de Araújo AC, et al. 2006. Export of organic carbon in run-off from an Amazonian rainforest blackwater catchment. Hydrological Processes 20: 2581-2597 DOI: 10.1002/hyp.6217

Weigelhofer G, Fuchsberger J, Teufl B, Welti N, Hein T. 2012. Effects of riparian forest buffers on instream nutrient retention in agricultural catchments. Journal of Environment Quality 41 (2): 373-379 DOI: $10.2134 /$ jeq2010.0436

Weisberg PJ, Mortenson SG, Dilts TE. 2013. Gallery Forest or Herbaceous Wetland? The Need for??Multi-Target Perspectives in Riparian Restoration Planning. Restoration Ecology 21 (1): 12-16 DOI: 10.1111/j.1526-100X.2012.00907.x

Weller DE, Baker ME. 2014. Cropland riparian buffers throughout chesapeake bay watershed: Spatial patterns and effects on nitrate loads delivered to streams. Journal of the American Water Resources Association 50 (3): 696-712 DOI: 10.1111/jawr.12207

Wilk J, Andersson L, Plermkamon V. 2001. Hydrological impacts of forest conversion to agriculture in a large river basin in Northeast Thailand. Hydrological Processes 15 (14): 2729-2748 DOI: 10.1002/hyp.229

Williams MR, Fisher TR, Melack J.M. 1997. Solute dynamics water and groundwater in a central Amazon catchment undergoing deforestation. Biogeochemistry 38: 303-335.

Williams MR, Melack JM. 1997. Solute export from forested and partially deforested catchments in the central Amazon. Biogeochemistry 38 (1): 67-102 DOI: 10.1023/A:1005774431820

Wohl E, Barros A, Brunsell N, Chappell NA, Coe M, Giambelluca T, Goldsmith S, Harmon R, Hendrickx JMH, Juvik J, et al. 2012. The hydrology of the humid tropics. Nature Climate Change 2 (9): 655-662 DOI: 10.1038/nclimate1556

Wright IR, Gash JHC, da Rocha HR, Roberts JM. 1996. Modelling surface conductance for Amazonian pasture and forest. In Amazonian Deforestation and Climate, Gash JHC, Nobre CA, Roberts JM, Victoria RL (eds). Wiley: Chichester; 437-458.

Yan J, Li K, Wang W, Zhang D, Zhou G. 2015. Changes in dissolved organic carbon and total dissolved nitrogen fluxes across subtropical forest ecosystems at different successional stages. Water Resources Research 51 (5): 3681-3694 DOI: 10.1002/2015WR016912

Yang WH, Liptzin D. 2015. High potential for iron reduction in upland soils. Ecology 96 (7): 2015-2020 DOI: 10.1890/14-2097.1

Zadroga, F. 1981. The hydrological importance of a montane cloud forest area of Costa Rica, in: Tropical Agricultural Hydrology, edited by: Lal, R. and Russell, E. W., John Wiley and Sons, New York, NY, 59-73.

Zanchi FB, Waterloo MJ, Tapia AP, Alvarado Barrientos MS, Bolson MA, Luizão FJ, Manzi AO, Dolman AJ. 2015. Water balance, nutrient and carbon export from a heath forest catchment in central Amazonia, Brazil. Hydrological Processes 3648 (March) DOI: 10.1002/hyp.10458

Zeinalzadeh K, Rezaei E. 2017. Determining spatial and temporal changes of surface water quality using principal component analysis. Journal of Hydrology: Regional Studies 13 (June): 1-10 DOI: 10.1016/j.ejrh.2017.07.002 
Zhang Y, Guo F, Meng W, Wang X-Q. 2009. Water quality assessment and source identification of Daliao river basin using multivariate statistical methods. Environmental Monitoring and Assessment 152 (1-4): 105-121 DOI: 10.1007/s10661-008-0300-z

Zhang X, Harvey KD, Hogg WD and Yuzyk TR. 2001. Trends in Canadian streamflow. Water Resour. Res. 37(4), 987-998, DOI: 10.1029/2000WR900357.

Zhao M, Zeng C, Liu Z, Wang S. 2010. Effect of different land use/land cover on karst hydrogeochemistry: A paired catchment study of Chenqi and Dengzhanhe, Puding, Guizhou, SW China. Journal of Hydrology 388 (1-2): 121-130 DOI: 10.1016/j.jhydrol.2010.04.034

Zhou W, Zhang Y, Schaefer DA, Sha L, Deng Y, Deng X-B, Dai K-J. 2013. The Role of Stream Water Carbon Dynamics and Export in the Carbon Balance of a Tropical Seasonal Rainforest, Southwest China (DL Kirchman, ed.). PLoS ONE 8 (2): e56646 DOI: 10.1371/journal.pone.0056646

Ziegler AD, Giambelluca TW, Tran LT, Vana TT, Nullet MA, Fox J, Vien TD, Pinthong J, Maxwell JF, Evett S. 2004, Hydrological consequences of landscape fragmentation in mountainous northern Vietnam: evidence of accelerated overland flow generation. J. Hydrol. 287(1-4), 124-146, DOI: 10.1016/j.jhydrol.2003.09.027.

Zimmermann B, Elsenbeer H, De Moraes JM. 2006. The influence of land-use changes on soil hydraulic properties: Implications for runoff generation. Forest Ecology and Management 222 (1-3): 29-38 DOI: 10.1016/j.foreco.2005.10.070 


\section{Appendices}

\section{Appendix A}

Table A.1. Descriptive statistics of the base streamflow hydrochemistry ${ }^{\text {. }}$

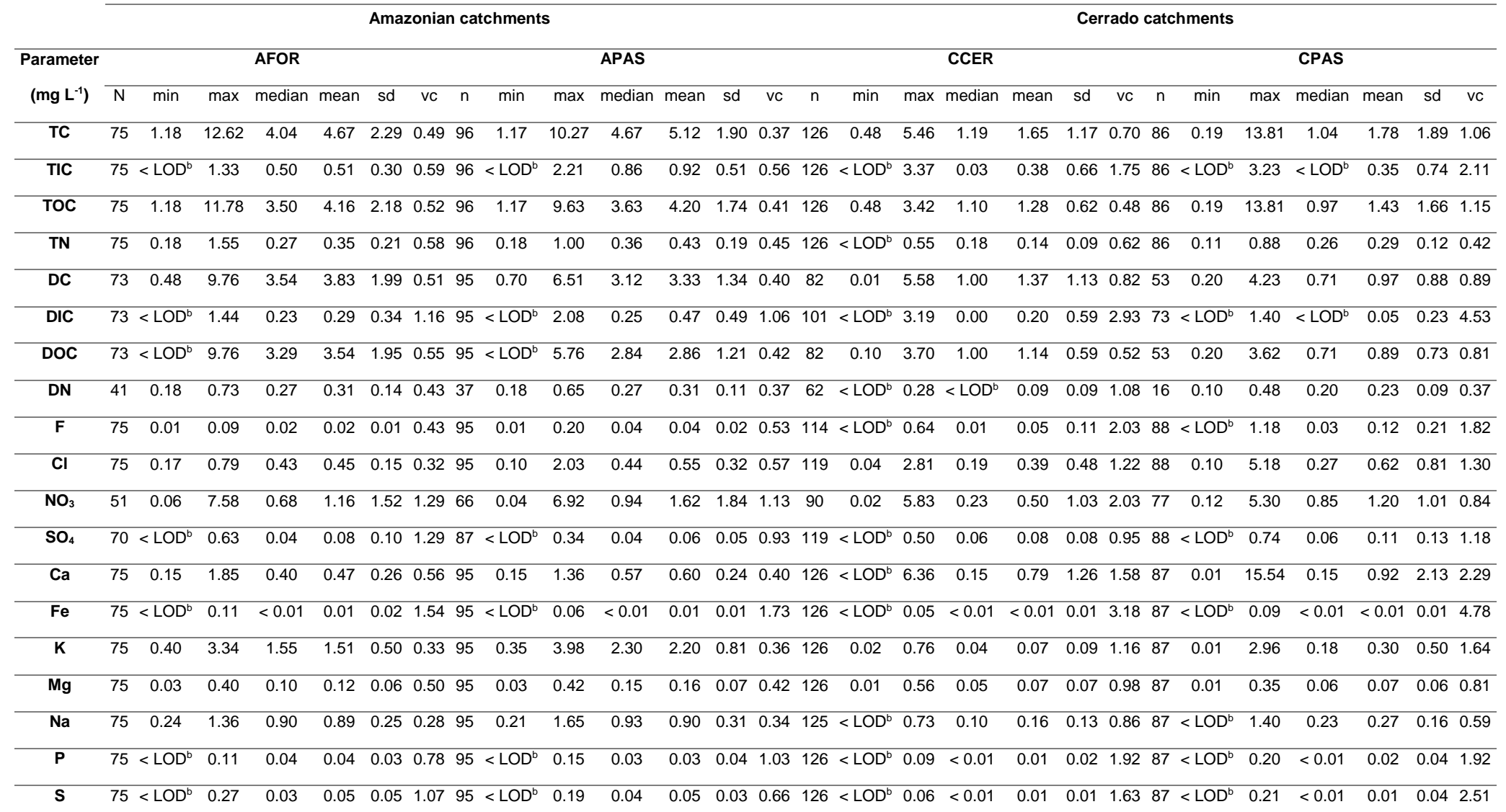

a The results of the base streamflow chemistry are related to sampling routines performed from 04/2013 to 07/2014 in the Amazonian catchments and from 12/2012 to 07/2014 in the Cerrado catchments.

${ }^{\mathrm{b}}$ LOD stands for limit of detection. 


\section{Appendix B}

Table A.2. Descriptive statistics of the storm streamflow hydrochemistrya

\begin{tabular}{|c|c|c|c|c|c|c|c|c|c|c|c|c|c|c|c|c|c|c|c|c|c|c|c|c|c|c|c|c|}
\hline \multirow{3}{*}{$\begin{array}{c}\text { Parameter } \\
\left(\mathrm{mg} \mathrm{L}^{-1}\right)\end{array}$} & \multicolumn{14}{|c|}{ Amazonian catchments } & \multicolumn{14}{|c|}{ Cerrado catchments } \\
\hline & \multicolumn{7}{|c|}{ AFOR } & \multicolumn{7}{|c|}{ APAS } & \multicolumn{7}{|c|}{ CCER } & \multicolumn{7}{|c|}{ CPAS } \\
\hline & $\mathrm{n}$ & $\min$ & $\max$ & median & mean & sd & vc & $\mathrm{n}$ & $\min$ & $\max$ & median & mean & sd & vc & $\mathrm{n}$ & $\min$ & $\max$ & median & mean & sd & vc & $\mathrm{n}$ & $\min$ & $\max$ & median & mean & sd & vc \\
\hline TC & 108 & 1.56 & 25.80 & 6.08 & 7.39 & 4.91 & 0.66 & 160 & 2.63 & 96.80 & 7.04 & 8.59 & 9.71 & 1.13 & 119 & 0.77 & 24.90 & 3.57 & 4.27 & 3.16 & 0.74 & 43 & 0.50 & 20.02 & 7.00 & 7.47 & 3.98 & 0.53 \\
\hline TIC & 108 & 0.08 & 2.20 & 0.35 & 0.53 & 0.47 & 0.87 & 160 & $<\mathrm{LOD}^{\mathrm{b}}$ & 2.70 & 0.52 & 0.64 & 0.49 & 0.76 & 119 & $<L^{2}$ & 3.79 & $<$ LOD $^{b}$ & 0.17 & 0.58 & 3.44 & 43 & $<$ LOD $^{b}$ & 4.00 & 0.08 & 0.64 & 1.11 & 1.73 \\
\hline TOC & 108 & 1.38 & 25.01 & 5.50 & 6.86 & 4.81 & 0.70 & 160 & 2.63 & 95.50 & 6.29 & 7.95 & 9.66 & 1.21 & 119 & 0.77 & 23.10 & 3.47 & 4.10 & 3.00 & 0.73 & 43 & 0.50 & 18.27 & 6.50 & 6.84 & 3.88 & 30.56 \\
\hline TN & 108 & 0.18 & 1.82 & 0.40 & 0.46 & 0.24 & 0.53 & 160 & 0.22 & 1.30 & 0.50 & 0.49 & 0.17 & 0.35 & 119 & 0.10 & 1.50 & 0.27 & 0.27 & 0.18 & 0.65 & 43 & 0.20 & 3.10 & 0.50 & 0.61 & 0.48 & $\begin{array}{ll}3 & 0.79\end{array}$ \\
\hline DC & 93 & 1.94 & 27.30 & 5.35 & 6.73 & 4.41 & 0.65 & 148 & 1.12 & 98.60 & 5.18 & 6.94 & 10.58 & 1.52 & 119 & 0.80 & 10.20 & 2.90 & 3.26 & 1.73 & 0.53 & 38 & 3.30 & 11.40 & 6.21 & 6.50 & 1.96 & 0.30 \\
\hline DIC & 46 & $<$ LOD $^{b}$ & 2.10 & 0.34 & 0.52 & 0.56 & 1.06 & 125 & $<\operatorname{LOD}^{\mathrm{b}}$ & 2.60 & 0.30 & 0.45 & 0.51 & 1.14 & 115 & $<L^{2} D^{b}$ & 2.25 & $<\operatorname{LOD}^{b}$ & 0.12 & 0.40 & 3.43 & 41 & $<$ LOD $^{b}$ & 3.90 & $<\mathrm{LOD}^{\mathrm{b}}$ & 0.62 & 1.10 & 1.75 \\
\hline DOC & 93 & 1.21 & 26.30 & 4.87 & 6.13 & 4.33 & 0.70 & 148 & 1.12 & 97.60 & 4.73 & & 10.49 & 1.61 & 119 & 0.80 & 8.22 & 28 & 3.13 & 1.62 & 0.51 & 38 & 210 & 10.90 & 545 & 5.81 & 2.03 & 0.34 \\
\hline DN & 91 & 0.18 & 1.46 & 0.36 & 0.42 & 0.23 & 0.55 & 117 & 0.27 & 0.90 & 0.40 & 0.42 & 0.15 & 0.34 & 65 & $<\mathrm{LOD}^{\mathrm{b}}$ & 0.91 & 01 & 0.22 & 0.11 & 0.49 & 35 & 0.10 & 2.10 & 0.40 & 0.49 & 0.37 & 0.75 \\
\hline$F$ & 109 & 0.01 & 3.62 & 0.02 & 0.07 & 0.35 & 5.03 & 159 & 0.01 & 0.10 & 0.03 & 0.03 & 0.01 & 0.42 & 119 & $<L^{2} D^{b}$ & 0.33 & 0.01 & 0.01 & 0.03 & 2.93 & 36 & $<\operatorname{LOD}^{b}$ & 1.23 & 0.04 & 0.19 & 0.30 & 1.51 \\
\hline Cl & 109 & 0.35 & 16.05 & 0.53 & 0.81 & 1.53 & 1.88 & 159 & 0.08 & 4.95 & 0.60 & 0.63 & 0.40 & 0.64 & 119 & 0.06 & 4.20 & 0.17 & 0.28 & 0.42 & 1.50 & 36 & 0.20 & 3.65 & 0.59 & 0.93 & 0.90 & 0.96 \\
\hline $\mathrm{NO}_{3}$ & 107 & 0.10 & 6.66 & 0.44 & 0.93 & 1.21 & 1.29 & 142 & 0.01 & 7.56 & 0.40 & 1.18 & 1.74 & 1.48 & 109 & $<\operatorname{LOD}^{\mathrm{b}}$ & 6.53 & 0.34 & 1.09 & 1.62 & 1.48 & 35 & 0.27 & 3.20 & 1.00 & 1.02 & 0.50 & 0.48 \\
\hline $\mathrm{SO}_{4}$ & 107 & & 1.03 & & 0.12 & 0.16 & 1.26 & 159 & 0.01 & 0.55 & & & 0.07 & 0.82 & 117 & 0.02 & & & 0.07 & 0.07 & 0.97 & 36 & & 0.38 & 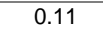 & 0.14 & 0.09 & 0.67 \\
\hline $\mathrm{Ca}$ & 109 & 0.22 & 2.65 & 0.48 & 0.70 & 0.53 & 0.77 & 160 & 0.09 & 3.71 & & 0.61 & 0.54 & 0.88 & 118 & 0.06 & 5.30 & & 0.41 & 0.84 & 2.02 & 42 & 0.08 & 1.10 & 0.45 & 1.43 & 1.88 & 31.30 \\
\hline $\mathrm{Fe}$ & 109 & $<$ LOD $^{b}$ & 0.06 & 0.01 & 0.01 & 0.02 & 1.04 & 160 & $<\operatorname{LOD}^{b}$ & 0.23 & 0.03 & 0.03 & 0.03 & 1.02 & 119 & $<\operatorname{LOD}^{b}$ & 0.11 & 0.01 & 0.02 & 0.02 & 1.09 & 42 & $<\operatorname{LOD}^{b}$ & 0.05 & $<0.01$ & 0.01 & 0.02 & 21.75 \\
\hline $\mathrm{K}$ & 109 & 0.91 & 3.62 & 1.87 & 1.96 & 0.46 & 0.23 & 160 & 0.31 & 4.11 & 2.51 & 2.54 & 0.53 & 0.21 & 118 & 0.02 & 1.68 & 0.16 & 0.23 & 0.23 & 0.98 & 42 & 0.15 & 2.80 & 0.50 & 0.60 & 0.45 & 0.73 \\
\hline Mg & 109 & 0.04 & 0.30 & 0.12 & 0.14 & 0.06 & 0.40 & 160 & 0.02 & 0.26 & 0.12 & 0.14 & 0.05 & 0.35 & 118 & 0.03 & 2.36 & 0.08 & 0.12 & 0.22 & 1.81 & 42 & 0.04 & 0.42 & 0.08 & 0.11 & 0.07 & 0.65 \\
\hline $\mathrm{Na}$ & 109 & 0.56 & 1.95 & 0.92 & 0.96 & 0.22 & 0.23 & 160 & 0.14 & 1.18 & 0.76 & 0.72 & 0.23 & 0.33 & 118 & 0.05 & 1.57 & 0.11 & 0.22 & 0.22 & 1.01 & 42 & 0.15 & 1.62 & 0.27 & 0.41 & 0.30 & 0.72 \\
\hline $\mathbf{P}$ & 109 & $<$ LOD $^{b}$ & 0.11 & $<$ LOD $^{b}$ & 0.02 & 0.03 & 1.45 & 160 & $<$ LOD $^{b}$ & 0.14 & 0.01 & 0.04 & 0.04 & 1.13 & 119 & $<\operatorname{LOD}^{b}$ & 0.11 & $<0.01$ & 0.02 & 0.03 & 1.39 & 42 & $<$ LOD $^{b}$ & 0.09 & $<0.01$ & 0.02 & 0.03 & 31.82 \\
\hline$s$ & 109 & $<\operatorname{LOD}^{\mathrm{b}}$ & 0.52 & 0.05 & 0.07 & 0.08 & 1.18 & 160 & $<L^{2 O D}{ }^{b}$ & 0.21 & 0.07 & 0.07 & 0.05 & 0.78 & 119 & $<\mathrm{LOD}^{\mathrm{b}}$ & 0.26 & 0.02 & 0.03 & 0.03 & 1.18 & 42 & $<$ LOD $^{b}$ & 0.09 & $<0.01$ & 0.01 & 0.03 & $\begin{array}{l}3 \\
1.76\end{array}$ \\
\hline
\end{tabular}

a The results of the storm streamflow chemistry are related to sampling obtained from 02/2013 to 02/2014 in the Amazon and Cerrado catchments.

${ }^{b}$ LOD stands for limit of detection. 


\section{Appendix C}

Table A.1. List of plant species and their respective family and occurrence in each surveyed plot.

\begin{tabular}{|c|c|c|c|c|c|c|c|c|c|}
\hline Family & Species & Plot 1 & Plot 2 & Plot 3 & Plot 4 & Plot 5 & Plot 6 & Plot 7 & Plot 8 \\
\hline \multirow{2}{*}{ Anacardiaceae } & Tapirira guianensis & - & - & - & - & - & 2 & - & - \\
\hline & Tapirira obtusa & - & - & 4 & 17 & - & - & - & - \\
\hline \multirow{2}{*}{ Annonaceae } & Xylopia aromatica & - & - & - & 1 & 1 & - & 1 & 1 \\
\hline & Xylopia cf. chivantinensis & 1 & - & - & - & - & - & - & - \\
\hline \multirow{2}{*}{ Apocynaceae } & Aspidosperma cf. excelsum & 1 & - & - & - & - & - & - & - \\
\hline & Himatanthus articulatus & - & - & 1 & - & - & - & - & - \\
\hline Bignoniaceae & Jacaranda copaia & - & 1 & - & - & - & - & - & - \\
\hline Boraginaceae & Cordia bicolor & 2 & 1 & - & - & - & - & - & - \\
\hline \multirow{4}{*}{ Burseraceae } & Dacryodes microcarpa & - & - & 1 & - & - & - & - & - \\
\hline & Protium cf. heptaphyllum & 1 & - & 1 & 1 & - & - & - & - \\
\hline & Protium pilosissimum & - & - & 1 & - & - & - & - & - \\
\hline & Protium spruceanum & - & 1 & 13 & 3 & - & - & - & - \\
\hline Ebenaceae & Diospyros sericea & - & - & 1 & - & - & - & - & - \\
\hline Elaeocarpaceae & Sloanea sinemariensis & 1 & - & - & - & - & - & - & - \\
\hline \multirow{5}{*}{ Euphorbiaceae } & Alchornea glandulosa & - & - & 2 & - & 2 & 3 & 1 & - \\
\hline & Alchornea discolor & - & - & - & - & - & 3 & 1 & 5 \\
\hline & Croton cf. palanostigma & 1 & - & - & 1 & - & - & - & - \\
\hline & Mabea fistulifera & 1 & 1 & - & - & - & - & - & - \\
\hline & Maprounea guianensis & - & - & - & - & 3 & 7 & 7 & - \\
\hline \multirow{2}{*}{ Fabaceae } & Bowdichia virgilioides & - & - & - & - & - & - & 1 & - \\
\hline & Hydrochorea corymbosa & 2 & - & - & - & - & - & - & - \\
\hline
\end{tabular}




\begin{tabular}{|c|c|c|c|c|c|c|c|c|c|}
\hline Family & Species & Plot 1 & Plot 2 & Plot 3 & Plot 4 & Plot 5 & Plot 6 & Plot 7 & Plot 8 \\
\hline & Inga pezizifera & - & 2 & 1 & - & - & - & - & - \\
\hline & Inga vera & - & - & 3 & 3 & - & - & - & - \\
\hline & Ormosia paraensis & 1 & - & 1 & - & - & - & - & - \\
\hline & Tachigali vulgaris & - & - & - & - & 5 & 3 & 1 & - \\
\hline Humiriaceae & Sacoglottis guianensis & 3 & 1 & - & 1 & - & - & - & - \\
\hline \multirow{4}{*}{ Hypericaceae } & Vismia gracilis & - & - & - & - & - & 1 & - & - \\
\hline & Vismia angusta & 2 & - & - & - & - & - & 1 & - \\
\hline & Vismia guianensis & - & - & - & - & - & - & - & 5 \\
\hline & Vismia macrophylla & - & - & - & - & - & - & 1 & \\
\hline Icacinaceae & Emmotum nitens & - & - & - & - & - & 1 & - & 1 \\
\hline \multirow{3}{*}{ Lauraceae } & Nectandra cuspidata & 1 & - & - & - & - & 2 & - & - \\
\hline & Ocotea aciphylla & 2 & 3 & - & - & - & - & - & - \\
\hline & Ocotea leucoxylon & 1 & 1 & 1 & - & - & - & - & - \\
\hline \multirow{5}{*}{ Malpighiaceae } & Byrsonima arthropoda & - & 1 & - & - & - & - & - & - \\
\hline & Byrsonima chrysophylla & - & 1 & - & 1 & - & - & - & - \\
\hline & Byrsonima clausseniana & - & - & - & - & 1 & 2 & 6 & 3 \\
\hline & Byrsonima laxiflora & - & - & - & - & 2 & - & - & - \\
\hline & Diplopterys cf. lucida & - & - & - & - & - & 1 & 1 & - \\
\hline \multirow{5}{*}{ Melastomataceae } & Bellucia grossularioides & 2 & 1 & - & - & - & - & - & - \\
\hline & Macairea cf. pachyphylla & - & - & - & - & 1 & - & 2 & 1 \\
\hline & Miconia albicans & - & - & - & - & 1 & 6 & 2 & - \\
\hline & Miconia cuspidata & 1 & 6 & - & - & 5 & 3 & 3 & 1 \\
\hline & Pleroma stenocarpum & - & - & - & - & & 14 & 28 & 35 \\
\hline \multirow{2}{*}{ Moraceae } & Pseudolmedia cf. laevigata & - & 1 & - & - & - & - & - & - \\
\hline & Pseudolmedia laevis & 1 & 1 & - & - & - & - & - & - \\
\hline
\end{tabular}




\begin{tabular}{|c|c|c|c|c|c|c|c|c|c|}
\hline Family & Species & Plot 1 & Plot 2 & Plot 3 & Plot 4 & Plot 5 & Plot 6 & Plot 7 & Plot 8 \\
\hline Myristicaceae & Virola sebifera & - & - & - & - & - & - & 4 & 1 \\
\hline Myrtaceae & Myrcia splendens & - & - & - & - & - & 1 & 1 & - \\
\hline Olacaceae & Minquartia guianensis & 4 & 4 & 1 & - & - & - & - & - \\
\hline Polygalaceae & Bredemeyera divaricata & - & - & - & 1 & - & - & - & - \\
\hline Primulaceae & Myrsine coriacea & - & - & - & 1 & - & - & 2 & - \\
\hline Rubiaceae & Alibertia edulis & - & - & - & 1 & - & - & 1 & 3 \\
\hline \multirow{4}{*}{ Sapotaceae } & Ecclinusa cf. ramiflora & 1 & - & - & - & - & - & - & - \\
\hline & Micropholis guyanensis & - & 2 & - & - & - & - & - & - \\
\hline & Micropholis venulosa & - & - & 2 & - & - & - & - & - \\
\hline & Pouteria cf. filipes & - & - & 1 & - & - & - & - & - \\
\hline Simaroubaceae & Simarouba amara & - & - & 1 & 1 & - & 23 & 1 & - \\
\hline Siparunaceae & Siparuna guianensis & - & - & - & - & - & - & 1 & - \\
\hline Styracaceae & Styrax ferrugineus & - & - & - & - & - & - & 1 & - \\
\hline Symplocaceae & Symplocos sp. & - & - & - & - & 5 & 4 & - & - \\
\hline Dead & - & 1 & 4 & 3 & 3 & 4 & 4 & 5 & 4 \\
\hline Not Identified & - & - & - & 1 & - & - & - & - & - \\
\hline
\end{tabular}




\section{Appendix D}

Table A.2. Descriptive statistics of the water quality parameters.

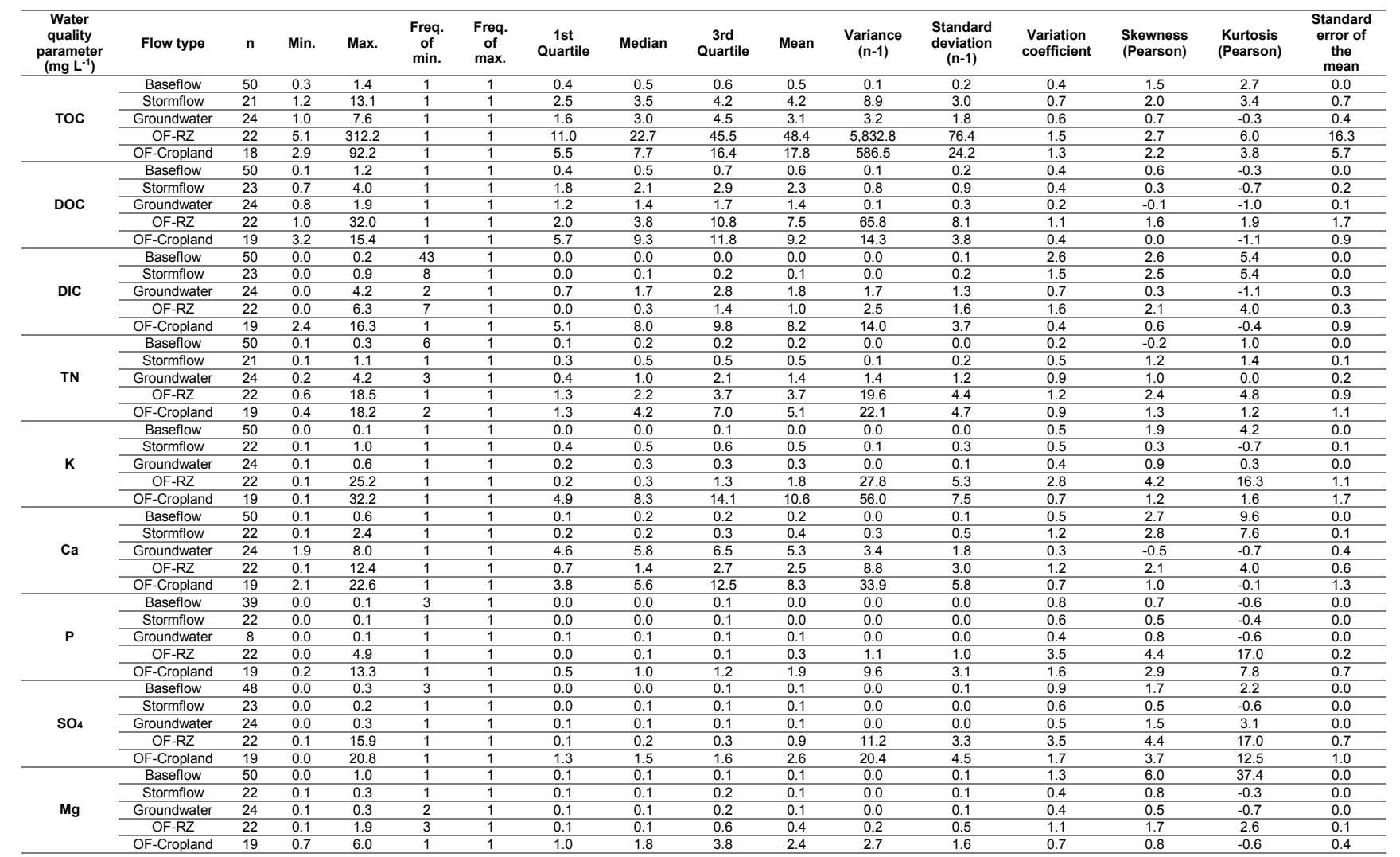


